UNIVERSIDADE DE SÃO PAULO

INSTITUTO DE GEOCIÊNCIAS

\title{
PATRIMÔNIO GEOLÓGICO EM ÁREAS DE PROTEÇÃO AMBIENTAL: UBATUBA-SP
}

Priscila Lopes de Abreu Santos

Orientadora: Profa. Dra. Maria da Glória Motta Garcia

$$
\text { DISSERTAÇÃO DE MESTRADO }
$$

Programa de Pós-graduação em Geociências (Mineralogia e Petrologia)

VERSÃO CORRIGIDA

SÃO PAULO

2014 
PRISCILA LOPES DE ABREU SANTOS

\section{PATRIMÔNIO GEOLÓGICO EM ÁREAS DE PROTEÇÃO AMBIENTAL:} UBATUBA-SP

Dissertação de Mestrado submetida ao Programa de PósGraduação em Geociências (Mineralogia e Petrologia), Instituto de Geociências, Universidade de São Paulo - USP, como parte dos requisitos à obtenção do título de Mestre em Ciências (Geologia).

Área de Concentração: Mineralogia Experimental e Aplicada

Orientadora: Profa. Dra. Maria da Glória Motta Garcia

SÃO PAULO 
Autorizo a reprodução e divulgação total ou parcial deste trabalho, por qualquer meio convencional ou eletrônico, para fins de estudo e pesquisa, desde que citada a fonte.

Ficha catalográfica preparada pelo Serviço de Biblioteca e Documentação do Instituto de Geociências da Universidade de São Paulo

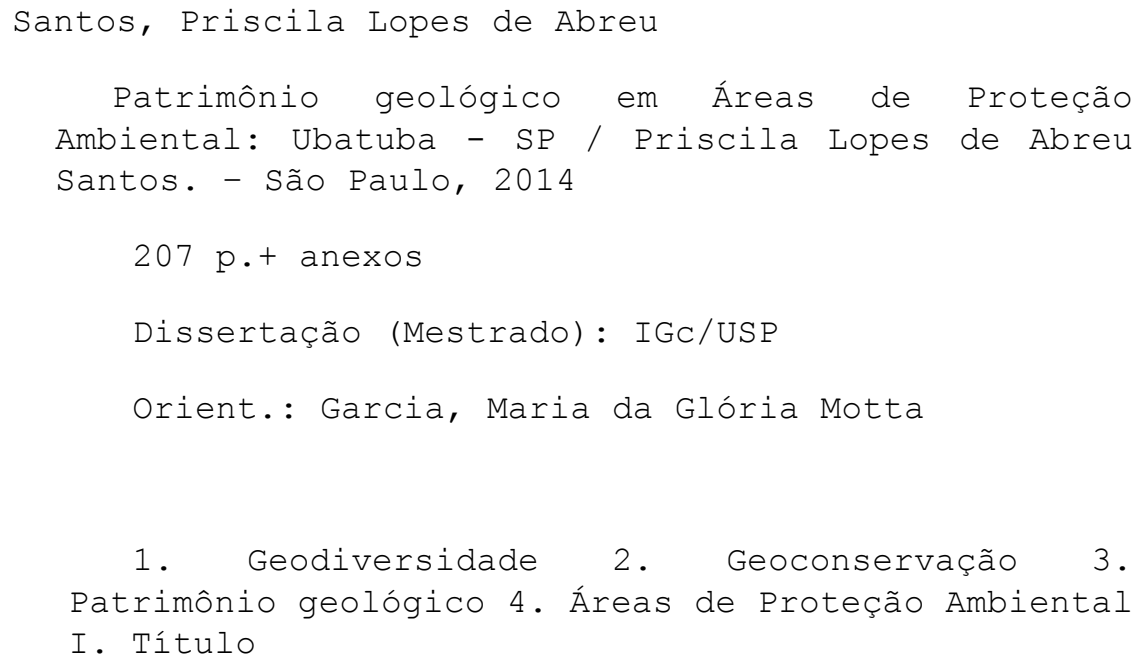


Dedico este trabalho aos meus queridos pais Manoel e Verita e a minha "pepina" irmã Alessandra. 


\section{AGRADECIMENTOS}

Gostaria de manifestar os meus agradecimentos a todos aqueles que de alguma forma contribuíram para a realização deste trabalho, porém muito especialmente:

Aos meus familiares Manoel Santos, Verita Santos, Alessandra Santos e Felipe Nascimento, que estiveram sempre presentes durante esta longa jornada, pelo carinho, incentivo e compreensão.

À Profa. Dra. Maria da Glória Motta Garcia, por me orientar com tanta dedicação e paciência ao longo destes quatro anos, pela confiança e estímulo durante a realização deste trabalho. Em especial pela sua contribuição no meu crescimento acadêmico e profissional.

À Coordenação de Aperfeiçoamento de Pessoal de Nível Superior - CAPES pelo apoio financeiro durante o desenvolvimento deste trabalho.

Ao Núcleo de Apoio à Pesquisa ao Patrimônio Geológico e Geoturismo GeoHereditas por viabilizar a minha participação em diferentes eventos nacionais e internacionais.

À amiga e companheira de trabalho Rachel Prochoroff, pelas discussões, ensinamentos, por partilhar momentos de alegrias e tristezas, em especial pelo incentivo e durante a realização deste trabalho.

Aos amigos e companheiros de pós-graduação e Carlos Eduardo Mazoca, Diego Machado, Eva Mori, Fernanda Reverte e Thiago Pereira, por dividir momentos de trabalhos e diversão.

Aos amigos de longa data Beatriz Scigliano, Herlândia Barros, Lúcia Regina Souza, Marcelha Landim e Miguel Ángel Sanmatín, por tornarem minha vida mais alegre.

Aos professores do Instituto de Geociências da Universidade de São Paulo. Em especial ao Prof. Dr. Daniel Atencio e Profa. Dra. Eliane Del Lama, pelo incentivo e ensinamentos ao longo destes anos.

Ao Prof. Dr. José Bernardo Brilha, por me receber com tanto zelo durante a realização do estágio na Universidade do Minho, Braga em outubro de 2013. 
"Quem, de três milênios, não é capaz de se dar conta, vive na ignorância, na sombra, a mercê dos dias, do tempo."

[Goethe] 
"Se hacen eternas cuando las quieren Y siempre viven y nunca mueren Cuando se duermen son indefensas $Y$ se despiertan cuando las piensas Y las atacan y las defienden Las mas valiosas nunca se venden Alcanzan todo lo que desean Así de grande son las ideas”

[Calle 13] 


\section{RESUMO}

SANTOS, P.L.A. Patrimônio Geológico em Áreas de Proteção Ambiental: Ubatuba, São Paulo. 2014. 206p. Dissertação de Mestrado - Instituto de Geociências, Universidade de São Paulo, São Paulo, 2014.

O município de Ubatuba, localizado no litoral norte do estado de São Paulo, constitui um dos principais destinos turísticos da região. A geodiversidade e a biodiversidade local formam um ambiente com exuberantes paisagens, constituídas principalmente por praias, costões rochosos e a Mata Atlântica que recobre a maior parte das escarpas da Serra do Mar. A região inclui três unidades de conservação: o Núcleo Picinguaba do Parque Estadual da Serra do Mar (PESM), o Parque Estadual da llha Anchieta e a APA Marinha do litoral norte do estado de São Paulo. Geologicamente, a área está inserida no Terreno Serra do Mar (Domínio Costeiro) da Faixa Ribeira, um dos orógenos da Província Mantiqueira. O inventário do patrimônio geológico de Ubatuba foi realizado considerando como contexto geológico (framework) a evolução do Supercontinente Gondwana. Para tanto, os geossítios foram acessados pelo percurso de diversas trilhas ecoturísticas inseridas nas UC e costões rochosos ao longo da linha de costa de Ubatuba. Atualmente, este inventário é composto por dez geossítios, que foram agrupados de acordo com o interesse geológico principal e associação com os eventos na história do Gondwana Ocidental. São eles: Pedra do Sino de Ubatuba, Charnockito Ubatuba, Praia do Cedro do Sul, Praia da Ponta Aguda, Monzogranito llha Anchieta, Gruta que Chora, Brecha magmática llha Anchieta, Xenólitos do manto e cones de explosão, Pico do Corcovado e Pedreira Itamambuca. A quantificação dos geossítios foi feita utilizando-se três métodos: o de Brilha (2005), a plataforma GEOSSIT desenvolvida pelo Serviço Geológico do Brasil (CPRM), que para a composição das categorias avaliadas durante a quantificação se baseia nos métodos de Brilha (2005) e de Garcia-Cortés \& Carcavilla Urquí (2009) e, o método de Pereira (2010). Os resultados obtidos foram avaliados e discutidos a partir da comparação entre os parâmetros que os compõem e as adequações feitas para aplicação neste estudo. Ao final desta etapa, conclui-se que estes métodos necessitam ser discutidos e refinados até que se encontrem parâmetros e alternativas que melhor representem os diferentes contextos do território brasileiro. Finalmente, são apresentadas algumas propostas para valorização e divulgação dos geossítios com maior potencial turístico, que podem ser desenvolvidas inicialmente junto às $\mathrm{UC}$ e aos demais setores comerciais (artesanato, hotelaria e alimentação) da região como forma de proteger o meio natural e fomentar o turismo local por meio do geoturismo. Os resultados deste trabalho pretendem ser uma fonte de dados que subsidie pesquisas científicas na área abrangente, que integra o projeto de inventário do patrimônio geológico de todo o litoral paulista e para futuras ações de ordenamento territorial.

Palavras-chave: Geoconservação, Geoturismo, Patrimônio Geológico, Ubatuba, Litoral Norte de São Paulo. 


\section{ABSTRACT}

SANTOS, P.L.A. Geological Heritage in Areas of Environmental Protection: Ubatuba, São Paulo. 206p. 2014. Dissertação de Mestrado - Instituto de Geociências, Universidade de São Paulo, São Paulo, 2014.

The city of Ubatuba is on the north coast of the state of São Paulo and is one of the major tourist destinations in the region. The local biodiversity and geodiversity form an environment with lush landscapes, sandy beaches, rocky shores and rain forest that covers most of the Serra do Mar slopes. The region comprises three protected areas: the Picinguaba Center in Serra do Mar State Park (PESM), Anchieta Island State Park and the Marine APA of the northern coast of São Paulo. The area is part of the Serra do Mar Domain, in the Ribeira Belt, one of the orogens that form the Mantiqueira Geological Province.The inventory of the geoheritage of Ubatuba was carried out considering the evolution of the Gondwana Supercontinent as a geological context (framework). Both the ecotouristic trails in the Conservation Units (UC) and the rocky shores along Ubatuba coastline were visited in order to access the geosites. This inventory currently consists of ten geosites, which were then grouped according to the main geological interest and association with the events in the history of Western Gondwana. They are: Pedra do Sino in Ubatuba, Ubatuba Charnockite, Cedro do Sul Beach, Ponta Aguda Beach, Monzogranite in Anchieta Island, The Weeping Cave, Magmatic Breccia in Anchieta Island, The mantle xenoliths and the explosion cones, Corcovado Peak and Itamambuca Quarry. Quantification of the geosites was made using the following three methods: Brilha (2005), the GEOSSIT platform - developed by the Geological Survey of Brazil (CPRM), which was based upon Brilha's (2005) and Garcia-Cortés \& Carcavilla Urquí's (2009) for the composition of the categories that are assessed during quantification - , and Pereira (2010). Results were evaluated and the discussion was based on the comparison of the parameters that compose them and the adjustments made to their application in this study. It was possible to conclude that these methods need to be discussed and refined until parameters and alternatives that better represent the different contexts of the Brazilian territory are developed. Finally, in order to develop and promote potentially touristic geosites, we present ideas that can be initially developed with the UCs and other commercial sectors in the region (craft stores, hotels and restaurants), so as to protect the environment and nurture local tourism through geotourism. The results of this study are intended as a source of data which may support future scientific research in the broader area that integrates the inventory of geoheritage of the whole northern coast of the state of São Paulo.

Key words: Geoconservation, Geoheritage, Geotourism, Ubatuba, Nothern Shore of São Paulo. 


\section{RESUMEN}

SANTOS, P.L.A. Patrimonio Geológico en Áreas Protegidas: Ubatuba, São Paulo. 2014. 206p. Tesis de Maestría - Instituto de Geociéncias, Universidade de São Paulo, São Paulo, 2014.

El municipio de Ubatuba, ubicado en el litoral norte del estado de São Paulo, es uno de los principales destinos turísticos de la región. La biodiversidad y geodiversidad local forman un entorno con exuberantes paisajes, compuestas, principalmente, por playas arenosas, costas rocosas y la Mata Atlántica, que recubre la mayor parte de las escarpas de la Serra do Mar. La región incluye tres áreas protegidas: el Parque Estatal Serra do Mar (PESM), el Parque Estatal Ilha Anchieta (PEIA) y el Área de Preservación Ambiental (APA) marina de la costa norte de São Paulo. Geológicamente, el área se inserta en el Terreno Serra do Mar (Dominio Costero) del cinturón Ribeira, uno de los orógenos de la Provincia Mantiqueira. El inventario del patrimonio geológico de Ubatuba se llevó a cabo teniendo en cuenta el contexto geológico (framework) relacionado a la evolución del Supercontinente Gondwana. Por lo tanto, el reconocimiento de los geositios se realizó mediante el acceso por rutas ecoturísticas en las áreas protegidas a lo largo de la costa de Ubatuba. Actualmente, el inventario se compone de diez geositios, agrupados según el interés geológico y su asociación con los eventos en la historia de Gondwana Occidental. Son ellos: Pedra do Sino de Ubatuba, Charnockito Ubatuba, Praia do Cedro do Sul, Praia da Ponta Aguda, Monzogranito Ilha Anchieta, Gruta que Chora, Brecha magmática Ilha Anchieta, Xenólitos do manto e cones de explosão (Xenolitos del manto y conos de explosión), Pico do Corcovado y Pedreira Itamambuca. La cuantificación de los geositios se realizó por tres métodos: el primero desarrollado por Brilha (2005); el segundo, conforme la plataforma GEOSSIT, desarrollada por el Servicio Geológico de Brasil (CPRM), formada por la combinación del método de Brilha (2005) y el de García-Cortés \& Carcavilla Urquí (2009); y el tercero, el método de Pereira (2006). Los resultados obtenidos fueron evaluados y discutidos mediante la comparación entre los parámetros que componen los distintos métodos, además de los ajustes realizados para la aplicación en este estudio. Al final de esta etapa, se concluyó que se deben discutir dichos métodos y refinarlos hasta que se encuentren parámetros alternativos que mejor representen los distintos contextos del territorio brasileño. Por fin, se presentan algunas propuestas para la valoración y divulgación de los geositios de mayor interés turístico que se pueden desarrollar, inicialmente, en participación con las áreas protegidas y con los demás sectores comerciales (artesanía, hostelería y alimentación) de la región, de modo a proteger el entorno natural y fomentar el turismo local a través del geoturismo. Los resultados de este estudio pretenden ser una fuente de datos que subsidie el futuro de la investigación científica en el ámbito general que comprende el proyecto de inventario del patrimonio geológico de toda la costa del estado de São Paulo y para acciones de planificación regional.

Palabras clave: Geoconservación, Geoturismo, Patrimonio Geológico, Ubatuba, Costa Norte de São Paulo. 
SUMÁRIO

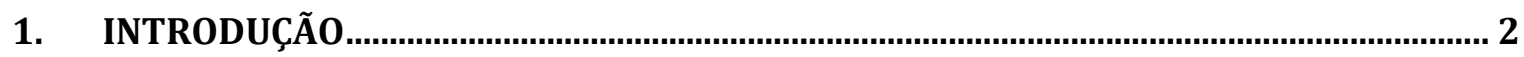

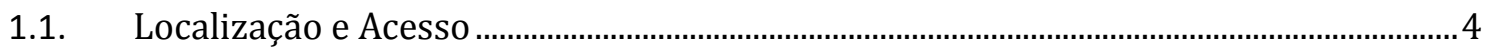

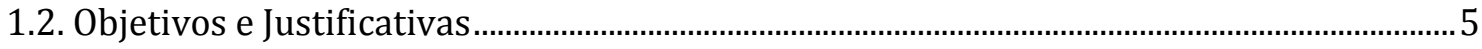

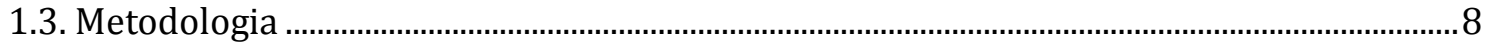

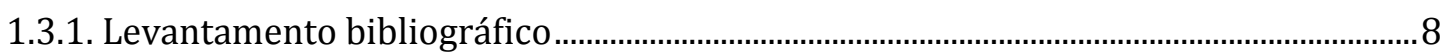

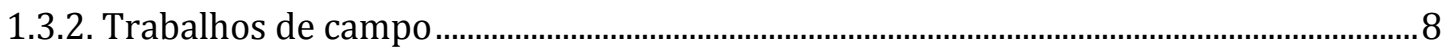

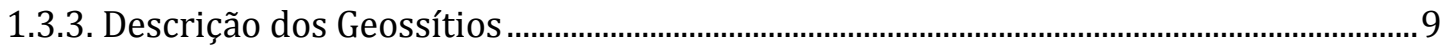

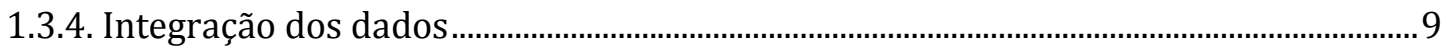

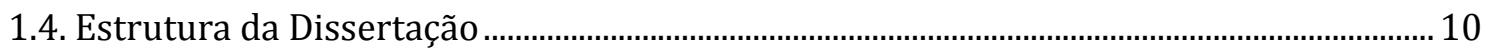

2. GEODIVERSIDADE PATRIMÔNIO GEOLÓGICO E GEOCONSERVAÇÃO ...........................11

2.1. Geodiversidade: conceitos e valores................................................................................... 11

2.2. Patrimônio Geológico e Geoconservação................................................................................. 15

2.2.1. Estratégias de Geoconservação.......................................................................................17

2.2.1.1. Etapa de invetário..................................................................................................... 17

2.2.1.2. Etapa de Quantificação........................................................................................18

2.2.1.3. Etapa de Classifcação..............................................................................................18

2.2.1.4. Etapa de Conservação...........................................................................................18

2.2.1.5. Etapa de valorização e divulgação do patrimônio geológico...........................19

2.2.1.6. Etapa de monitoramento.......................................................................................19

2.3. Panorama internacional das estratégias de Geoconservação...............................................20

2.4. Panorama nacional das estratégias de Geoconservação......................................................... 24

2.5. Geoturismo: aspectos históricos, definições e planejamento ……………………………..... 26

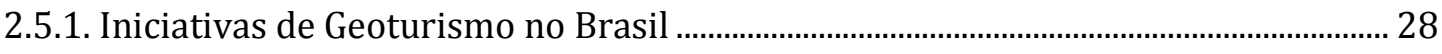


3.1. As Unidades de Conservação do estado de São Paulo..........................................................33

3.1.1. O Parque Estadual da Ilha Anchieta.................................................................................

3.1.2. O Parque Estadual da Serra do Mar - Núcleo Picinguaba..............................................36

3.1.3. A APA Marinha do Litoral Norte do Estado de São Paulo ..............................................37

3.2. Plano de Manejo e Uso Público ………………...................................................................38

3.3. Interpretação Ambiental no Contexto das Unidades de Conservação: definição e meios interpretativos

4. GEODIVERSIDADE DO MUNICÍPIO DE UBATUBA

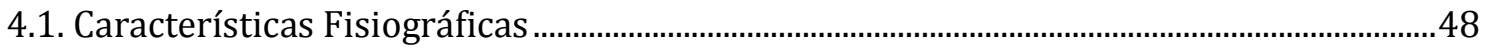

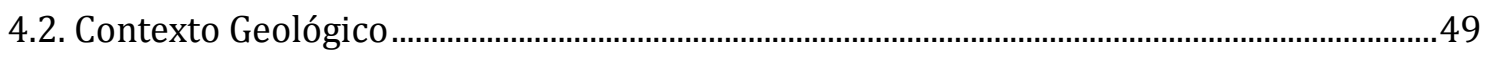

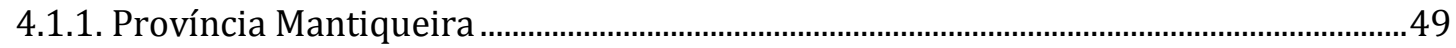

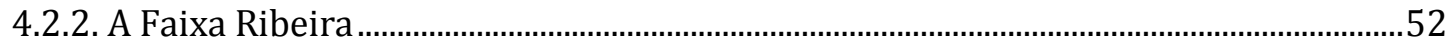

4.2.3. Terreno Serra do Mar (Domínio Costeiro)....................................................................... 54

4.3. Geodiversidade o Município de Ubatuba ...................................................................................5

4.3.1. Os valores da Geodiversidade de Ubatuba.......................................................................61

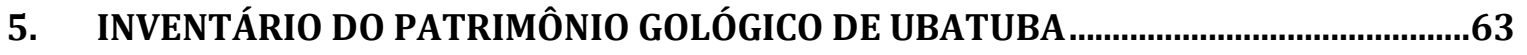

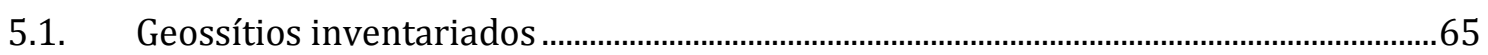

5.1.1. Geossítio da Charnockito Ubatuba ……...........................................................................65

5.1.2. Geossítio da Praia do Cedro do Sul....................................................................................72

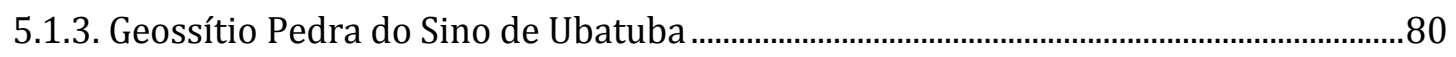

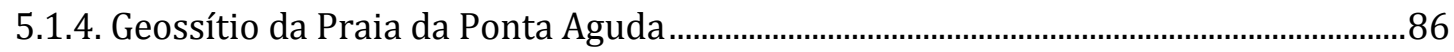

5.1.5. Geossítio Monzogranito Ilha Anchieta …………………...................................................92

5.1.6. Geossítio Gruta que Chora...............................................................................................99

5.1.7. Geossítio Brecha Magmática Ilha Anchieta.................................................................... 108

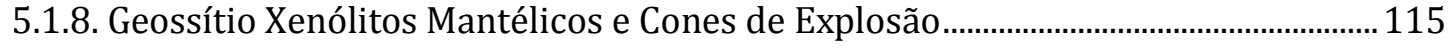

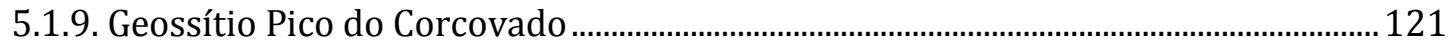

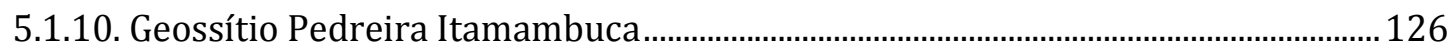


6.1. Metodologias adotadas para quantificação dos geossítios inventariados

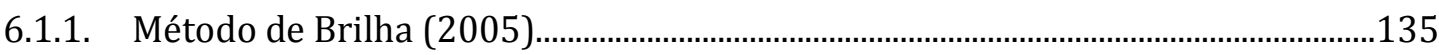

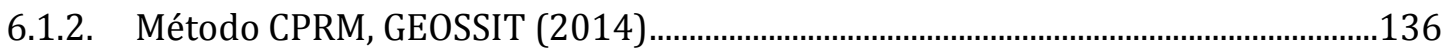

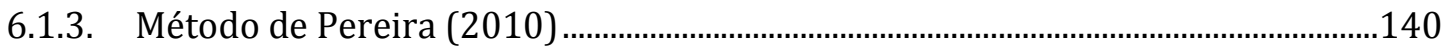

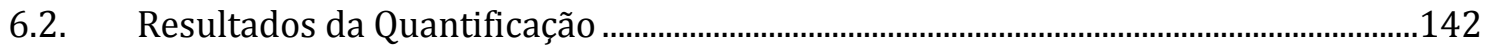

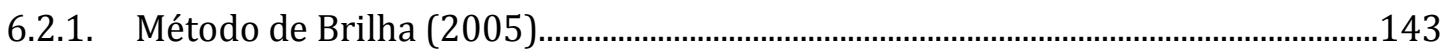

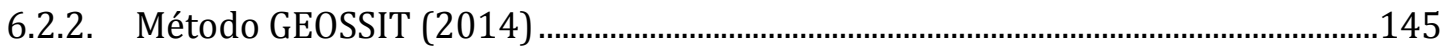

6.2.3. Método de Pereira (2010) ……….............................................................................150

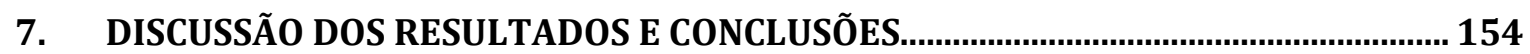

7.1. O Município de Ubatuba: contextualização da área..........................................................154

7.2. O inventário do Patrimônio Geológico de Ubatuba ..........................................................156

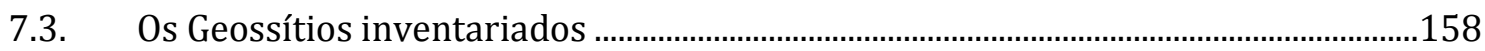

7.4. Etapa de quantificação dos geossítios ..............................................................................160

7.4.1. Método de Brilha (2005)...........................................................................................161

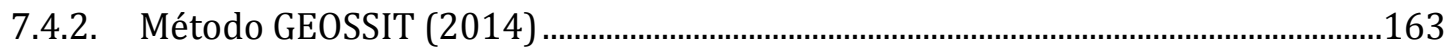

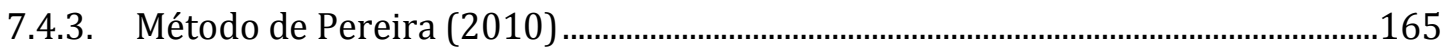

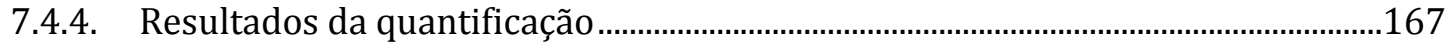

7.4.5. Conclusões sobre a quantificação ……………..........................................................185

7.5. As Unidades de Conservação e a gestão do Patrimônio Geológico de Ubatuba.....187

7.5.1. Ações pontuais para os geossítios de Ubatuba ............................................................188

7.6. Conclusões e perspectiva para estudos futuros ..................................................................195

REFERÊNCIAS BIBLIOGRÁFICAS..........................................................................................197

ANEXOS 


\section{LISTA DE FIGURAS}

\section{CAPÍTULO 1}

Figura 1.1.1 - Mapa de localização do Litoral Norte de São Paulo com destaque para Ubatuba.

Figura 1.1.2 - Mapa das Unidades de Conservação do Município de Ubatuba, com destaque para o Núcleo Picinguaba do Parque Estadual da Serra do Mar, Parque Estadual da Ilha Anchieta e APA Marinha do Litoral Norte.

\section{CAPÍTULO 3}

Figura 3.3.1 - Exemplos de placas de sinalização de atrativos turísticos. Fonte: Guia Brasileiro de Sinalização Turística (MT, 2014).

Figura 3.3.2a - Painel interpretativo "O Himalaia brasileiro", implantado pelo Projeto Caminhos Geológicos, RJ em 2001. Fonte: http://www.drm.ri.gov.br/...

Figura 3.3.2b - Painel interpretativo do Monumento Geológico Morro do Diabo, SP. Fonte: Instituto Geológico, 2014.

Figura 3.3.3 - a) Placa de sinalização da Trilha do Jequitibá e Trilha do Poção no Núcleo Caraguatatuba do PESM, b) Ao longo da Trilha do Jequitibá são encontradas placas sinalizando importantes elementos da biodiversidade local, como a palmeira Jussara, onde se extrai o palmito, que representa um importante ingrediente da gastronomia local (Fotos: Maria da Glória Motta Garcia).

Figura 3.3.4 - a) e b) Painéis interpretativos do Passeio Geológico da foz do Douro, Portugal.

Figura 3.3.5 - a) Vista para a entrada da associação Casa do Artesão de Ubatuba, b) artesanatos expostos para venda no interior da casa. Fonte: Sulfografia (2014) e Casa do Artesão (2014).

\section{CAPÍTULO 4}

Figura 4.2.1.1 - Províncias estruturais Brasileiras. (BIZZI, et al. 2003)

Figura 4.2.1.2 - a) Subdivisão do Sistema Orogênico Mantiqueira: o segmento setentrional é o Orógeno Araçuaí; o segmento central inclui a porção sul do Orógeno Brasília e os orógenos Ribeira e Apiaí; e o segmento meridional inclui os orógenos Dom Feliciano e São Gabriel. As cores roxo e laranja indicam os terrenos que alojam os arcos magmáticos neoproterozóicos (HEILBRON et al., 2004). No detalhe, as províncias estruturais brasileiras e a Província da Mantiqueira. Bizzi et al. (2003), modificado de Almeida et al., (1977); b) Configuração do Supercontinente Gondwana e localização das faixas móveis (HASUI, 2010).

Figura 4.2.2.1 - Seção estrutural esquemática NWSE para o Orógeno Ribeira. Terreno Ocidental (1 a 6); terreno Paraíba do Sul (7 e 8); terreno Oriental (9 - 
sequencia Cambuci; 10 - sequencia Italva; 11 - sequencia costeiro; 12 - arco magmático Rio Negro; 13 - granitos colisionais); terreno Cabo Frio (14 e 15). (Retirado de HEILBRON et al., 2004).....

Figura 4.2.2.2. Domínios tectônicos e principais estruturas da Província da Mantiqueira (BIZZI et al., 2003)......

Figura 4.2.3.1 - Entidades tectono-estratigráficas do estado de São Paulo. Fonte: CPRM (2006).

Figura 4.2.3.2 - Mapa geológico da região do litoral norte do Estado de São Paulo. Fonte: CPRM (2006).

Figura 4.3.1 - Mapa Geológico da Ilha Anchieta. Fonte: Instituto Geológico, São Paulo.

\section{CAPÍTULO 5}

Figura 5.1 - Mapa de localização dos geossítios inventariados em Ubatuba..... [64]

Figura 5.1.1.1 - Mapa de localização do geossítio Charnockito Ubatuba.

Figura 5.1.1.2 - a) Vista do geossítio Charnockito Ubatuba, situado na Praia do Prumirim; b) no afloramento nota-se que a rocha apresenta coloração rosada a acastanhada com porções esverdeadas, maciça e homogênea, equigranular, de granulometria de matriz média a grossa. (Fotos: Maria da Glória Motta Garcia).

Figura 5.1.1.2 - c) Vista do lajeado na altura da praia que se estende por cerca da 100m. (Foto: Maria da Glória Motta Garcia).

Figura 5.1.1.3 - Dique de granito fino e coloração rósea, que ocorre com orientação N30. Neste dique são encontrados enclaves de charnockito.

Figura 5.1.1.4 - Dique básico com orientação NE-SW (Fotos: Maria da Glória Motta Garcia).

[70]

Figura 5.1.1.5 - a) Contato entre o dique granítico com o charnockito. Neste local observa-se que foliação da rocha é interrompida pelo dique; b) Nesta foto observase em detalhe a foliação do charnockito, que em alguns locais encontra-se deformada (dobrada). (Fotos: Maria da Glória Motta Garcia).

Figura 5.1.1.6 - O geossítio tem grande interesse turístico, pois no local também há um quiosque construído sobre o afloramento com materiais locais e a culinária baseia-se em ingredientes típicos da região, de origem caiçara. (Foto: Maria da Glória Motta Garcia)......

Figura 5.1.2.1 - Mapa de Localização do geossítio Praia do Cedro do Sul. [72] 
Figura 5.1.2.3 - a) Vista do afloramento na área A do geossítio, observa-se a intrusão de um dique granítico. (Foto: Maria da Glória Motta Garcia).

Figura 5.1.2.3 - b) Detalhe do dique granítico com enclave da rocha encaixante, na borda observa-se uma na coloração da rocha, que passa de esverdeada para rosada característico do processo de "descharnockitização". (Foto: Maria da Glória Motta Garcia)

Figura 5.1.2.4 - a) Nesta foto observa-se o charnockito Ubatuba pouco alterado, com coloração esverdeada. Nota-se ainda a foliação da rocha que ocorre com orientação N140 mergulhando para SW e a presença de restos de um dique máfico.

Figura 5.1.2.4 - Em b) observa-se restos de dique lamprófiro concordante as famílias de fraturas N30; c) e d) Na parte A do geossítio são encontradas algumas feições que também agregam valor ao geossítios. Como exemplo, uma das formas de alteração observadas nas rochas, a esfoliação esferoidal, em que os agentes do intemperismo atuam na desagregação da rocha formando camadas que são destacadas do vértice para o centro, resultando na formação de blocos bem arredondados. (Fotos: Maria da Glória Motta Garcia).

Figura 5.1.2.5 - a) Vista para área B do geossítio Praia do Cedro do Sul. (Foto: Maria da Glória Motta Garcia)...

Figura 5.1.2.5 - b) e c) Vista a partir da parte (B) do geossítio. Observam-se grandes blocos de coloração róseo-esbranquiçado ao longo da praia e do costão rochoso. Estes blocos, de tamanho variados, são formados nos planos preferencias de uma família de fratura que formam um ângulo de aproximadamente $90^{\circ}$. (Foto: Érick Mota).

Figura 5.1.3.1 - Mapa de Localização do geossítio Pedra do Sino de Ubatuba, Praia da Santa Rita.

Figura 5.1.3.2 - a) Observa-se o charnockito Ubatuba bem foliado na direção N40, e granulometria média. Em b) observa-se a mudança na coloração da rocha passando de tons esverdeados a esbranquiçado e rosado. (Fotos: Maria da Glória Motta Garcia)

Figura 5.1.3.3 - Vista para o geossítio Pedra do Sino de Ubatuba. Os blocos disposto na praia, próximo ao afloramento, emitem o som de sino ao bater com um martelo

Figura 5.1.3.4 - a) Vista do afloramento para a praia da Santa Rita. Na rocha, observam-se duas famílias de fraturas localmente nas direções N60 mergulhando para SE e N120 mergulhando para SW. (Foto: Maria da Glória Motta Garcia)

Figura 5.1.3.4 - b) No processo de formação da esfoliação esferoidal os agentes do intemperismo atuam na desagregação dos blocos rochosos a partir dos vértices em 
direção ao centro formando camadas que posteriormente são destacada de modo semelhante as cascas de cebolas. Fonte: Material didático Curso Agronomia da Universidade de Brasília -UnB.

Figura 5.1.3.4 - c) e d) Blocos bem arredondados resultantes de esfoliação esferoidal que ocorre de acordo com os planos de fraqueza presentes na rocha. (Fotos: Maria da Glória Motta Garcia).

Figura 5.1.4.1 - Mapa de localização do geossítio Praia da Ponta Aguda.

Figura 5.1.4.2 - a) Vista do afloramento, que compõe o geossítio. Observa-se o contato entre o gnaisse granítico rosado com o biotita gnaisse. Neste local, observam-se ainda diferentes estruturas apresentadas em detalhe nas fotos: b), c), d), e) e f).

Figura 5.1.4.2 - b) Detalhe da foto (a), em que se observa um veio pegmatítico discordante a foliação da rocha. Nota-se que o gnaisse granítico ocorre em algumas porções com granulometria grossa e textura equigranular, c) observa-se em detalhe o contato plástico entre o gnaisse granítico e a uma rocha máfica e a formação de um bandamento, d) Detalhe do contato entre as duas rochas: biotita gnaisse à esquerda e gnaisse granítico à direita, cortado por finos veios pegmatíticos (em destaque).

$[89 / 90]$

Figura 5.1.4.2 - e) e f) Detalhe da foto (a) em que observam-se o dobramento das rochas, que ocorre de acordo com a foliação do gnaisse granítico.

Figura 5.1.4.3 - observa-se a presença de um dique sin-plutônico intrusivo ao biotita gnaisse.

Figura 5.1.5.1 - Mapa de localização do geossítio Monzogranito Ilha Anchieta.....[92]

Figura 5.1.5.2a - Vista do mar do geossítio Monzogranito Ilha Anchieta. (Foto: Maria da Glória Motta Garcia).

Figura 5.1.5.2b - Vista local do afloramento, que se estende por aproximadamente 100 metros ao longo da costeira. (Foto: Maria da Glória Motta Garcia).

Figura 5.1.5.3 - Imagens de algumas estruturas observadas no geossítio Monzogranito Ilha Anchieta: a) detalhe do principal litotipo observado, o biotitahornblenda monzogranito. Nota-se a presença de megacristais de microclínio que ocorrem de forma tabulares, com dimensão entre 2 e $4 \mathrm{~cm}$. Em b) e c) observa-se a concentração de alguns minerais como quartzo e feldspatos e minerais máficos como biotita. (Fotos: Maria da Glória Motta Garcia)

[95/96]

Figura 5.1.5.4 - a) Estratificação observada no quartzo monzogranito, com alternância de porções máficas da rocha para poções félsicas da rocha. Esta alternância, em geral ocorre com aproximadamente com $10 \mathrm{~cm}$ de espessura; b) observa-se além da estratificação a atitude das camadas com orientação geral, N-S e mergulhos médios para E. (Fotos: Maria da Glória Motta Garcia)... 
Figura 5.1.5.5 - a) e b) Diques máficos encontrados no geossítio. Observa-se em b, que este está concordante com o fraturamento NE-SW. (Foto: Maria da Glória Motta Garcia).

Figura 5.1.5.5 - c) Observam-se duas famílias de fraturas nas direções NE-SW, que formam um ângulo de $90^{\circ}$, (Foto: Maria da Glória Motta Garcia).....

Figura 5.1.6.1 Mapa de localização do geossítio Gruta que chora.

Figura 5.1.6.2 - Praia da Sununga vista do geossítio.

Figura 5.1.6.3 - a) Vista para a entrada da Gruta que Chora; b) Detalhe da foto (a) em que se observam famílias de fraturas formando um ângulo de $+/-90^{\circ}$ a partir da fratura principal N45. (Fotos: Fernanda Reverte).

Figura 5.1.6.3 - c) Vista interna da Gruta que Chora, no teto observa-se um dique basáltico e no chão, muitos blocos caídos, que são formados a partir das fraturas observadas na gruta; d) Dique basáltico no teto da gruta. (Fotos: Vanessa Mucivuna).

Figura 5.1.6.4 - a) Vista para o afloramento na Praia da Sununga, em que se observa a presença de diques máficos, interpretados como sin-plutônicos em contato com o granito. Estes diques apresentam porções da rocha encaixante e as estruturas de deformação. (Foto: Vanessa Mucivuna).

Figura 5.1.6.4 - b) No afloramento pode-se observar as relações de contato entre os diferentes tipos de rochas presentes: o granito, intrudido por diques rompidos (sinplutônicos) com porções da rocha encaixante, que são cortados por um dique máfico.

Figura 5.1.6.5 - Diques lamprófiros localizados próximo a Gruta que Chora (MELLO, 2008). (Foto: Vanessa Mucivuna)

Figura 5.1.6.6 - Primeira publicação sobre as lendas da Gruta que Chora no jornal "A Tribuna" em 1951. Artigo: Francisco Martins dos Santos. Fonte: http://www.atribuna.com.br/......

[107]

Figura 5.1.6.7 - a) Ilustração da lenda do Padre José de Anchieta em frente a Gruta que Chora afastando a Serpente. Por: Luiz Pagano. Fonte: http://blemya.blogspot.com.br/...

[107]

Figura 5.1.6.7 - b) Ilustração do encontro de Marcelina com a Serpente que habitava a gruta. Por: Luiz Pagano Fonte: http://blemya.blogspot.com.br/.....

Figura 5.1.7.1 - Mapa de localização do geossítio Brecha Magmática. [109]

Figura 5.1.7.2 - Vista do afloramento com aproximadamente 50 metros de extensão em que se observa o charnockito Ubatuba - principal litotipo observado no afloramento. (Foto: Maria da Glória Motta Garcia).

Figura 5.1.7.3 - a) A brecha magmática ocorre na forma de blocos grandes e médios que são produzidos por fraturamento. (Foto: Maria da Glória Motta Garcia). 
Figura 5.1.7.3 - b) e c) Blocos subangulares que compõem a brecha magmática, composta por charnockitos foliados e granitos formando um hibrido na rocha matriz de quartzo diorito; d) os blocos menores de granito incluídos no diabásio foram parcialmente derretidos, e em algumas porções ocorrem como gnaisse.

Figura 5.1.7.4 - a) Dique subvertical, orientado N45 concordante com a direção do falhamento NW (vista do mar). (Foto: Maria da Glória Motta Garcia)...

[113]

Fig.5.1.7.4 - b) Dique de diabásio com enclaves de charnockito e leucogranitos associados e c) Detalhe do contato entre dique de diabásio com leucogranito. (Fotos: Maria da Glória Motta Garcia).

Figura 5.1.8.1 - Mapa de localização do geossítio Xenólitos do manto e cones de explosão.

Figura 5.1.8.2 - a) Vista do dique lamprófiro que contém xenólitos. (Foto: Maria da Glória Motta Garcia).

Figura 5.1.8.2 - b) e c) Fragmentos de rochas (espinélio Iherzolitos) que se constituem em xenólitos com alteração marrom-esverdeado em dique lamprófiro na Praia Vermelha do Centro. (Foto: Maria da Glória Motta Garcia).

[118]

Figura 5.1.8.2 - d) Formação de xenólitos do manto. Fonte: http://www.cientic.com/portal/ (adaptado)... [119]

Figura 5.1.8.3 - a) e b) Feições cônicas com dimensões métricas a submétricas, interpretadas como cones de explosão ígneos em diques lamprófiros. (Foto: Maria da Glória Motta Garcia)...

$[119 / 120]$

Figura 5.1.8.3 - c) Perfil esquemático dos cones de explosão em dique lamprófiro na Praia Vermelha do Centro. (Autor: Érick Mota).

[120]

Figura 5.1.8.4 - No afloramento observam-se duas de fraturas nas direções N55 e N100 que acompanham o padrão regional um sistema de falhas neoproterozoicas, com direção ENE/EW. (Foto: Maria da Glória Motta Garcia).

Figura 5.1.9.1 - Mapa de localização do geossítio Pico do Corcovado. [122]

Figura 5.1.9.2 - Evolução geológica da Serra do Mar. Fonte: A Grande Barreira da Serra do Mar, 2004. De Álvaro Rodrigues dos Santos modificado de Almeida \& Carneiro (1998).

Figura 5.1.9.3 - Vista da Serra do Mar para o interior do continente onde se observa ao fundo a Serra da Mantiqueira, cuja formação está associada a Serra do Mar. Entre as escarpas das duas serras localiza-se o Rift Continental do Sudeste Brasileiro (RCSB). (Foto: Maria da Glória Motta Garcia)....

Figura 5.1.9.4 - a) Vista das escarpas da Serra do Mar e da planície costeira ao longo da costa de Ubatuba até a ponta de Trindade ao fundo. (Foto: Érick Mota). 
Figura 5.1.9.4 - b) Vista da planície costeira de Ubatuba, em que se pode notar a linha de costa mais recortada, formando praias de enseadas e praias de bolso, feições geomorfológicas típicas do litoral norte de São Paulo. À esquerda observa-se a Ilha Anchieta e a direita o Ilhote de dentro. (Foto: Érick Mota).

Figura 5.1.9.4 - c) Vista panorâmica do Pico do Corcovado. (Foto: Maria da Glória Motta Garcia).

Figura 5.1.10.1 - Mapa de localização do geossítio Pedreira Itamambuca

Figura 5.1.10.2 - a), b) e c) Pontos de antigas extrações de charnockito no bairro Sertãozinho do Prumirim, d) antiga extração de charnockito próximo à praia da Mãe Maria. (Fotos: Maria da Glória Motta Garcia).

Figura 5.1.10.3 - a) Vista do costão rochoso e Praia de Itamambuca; b) Vista da antiga pedreira Itamambuca e restos de uma antiga construção (Foto: Fernanda Reverte).

Figura 5.1.10.3 - c) e d) Afloramento de charnockito com marcas de explosivos. (Fotos: Fernanda Reverte).

Figura 5.1.10.4 - a) e b) Uso ornamental do charnockito Ubatuba como revestimento do monumento aos pescadores de Ubatuba na entrada da Cidade. (Fotos: Eliane Del Lama).

\section{CAPÍTULO 7}

Figura 7.5.1.6 - a) Vista para o pátio e ruínas do antigo presídio militar, b) Início da Trilha do Saco Grande.

Figura 7.5.1.6 - c) Durante o percurso da trilha são encontradas ruínas da antiga vila militar da Ilha Anchieta, d) Vista para o mar a partir do geossítio Monzogranito Ilha Anchieta.

Figura 7.5.1.7 - a) e b) Centro de visitantes do PEIA, onde são expostos diversos painéis que relatam a história da llha enquanto presídio militar e uma maquete da ilha com detalhes topográficos.

Figura 7.5.1.8 - a) e b) Atividades realizadas durante o curso de Introdução às Geociências oferecido no Núcleo Picinguaba do PESM em 2012. 


\section{LISTA DE TABELAS}

\section{CAPÍTULO 3}

Tabela 3.2.1. Principais tipos de uso permitidos nas Unidades de Conservação. Fonte: DAP/SBF/MMA, 2009.

[39]

\section{CAPÍTULO 6}

Tabela 6.1.1.1. Critérios de quantificação de relevância dos geossítio. Adaptada de Brilha (2005).

Tabela 6.1.1.2. Parâmetros analisados para classificação dos geossítios no âmbito internacional ou nacional e regional ou local.

Tabela 6.1.1.3. Fórmula para obtenção do valor final dos geossítios

Tabela 6.1.2.1. Critérios de quantificação de relevância dos geossítios utilizados na plataforma GEOSSIT (2014). Adaptada de Brilha (2005) e Garcia-Cortés \& Urquí (2009).

Tabela 6.1.2.2. Fórmulas para o cálculo a relevância dos geossítios

Tabela 6.1.2.3 - Parâmetros para o cálculo de Interesse didático (Id), Científico (Ic) e Turístico (It) no GEOSSIT. CPRM (2014) adaptada Garcia-Cortés \& Urquí (2009). [139]

Tabela 6.1.2.4 - a) Critérios para o cálculo da Prioridade de Proteção dos geossítios no GEOSSIT; b) "Ranking" na Prioridade de Proteção dos geossítios. CPRM (2014) adaptada Garcia-Cortés \& Urquí (2009).

Tabela 6.1.3.1 Critérios de quantificação de relevância dos geossítio. Adaptada de Pereira (2010). [140/141]

Tabela 6.1.3.2. Fórmulas para o cálculo do valor da relevância dos geossítio. Adaptada de Pereira (2010).

Tabela 6.1.3.3. Fórmulas para o cálculo do valor de uso dos geossítio. Adaptada de Pereira (2010) [142]

Tabela 6.1.3.4. Critérios para a seriação da relevância dos geossítio. Adaptada de Pereira (2010)

Tabela 6.2.1.1 - Resultado final da quantificação $(Q)$, ranking de geossítios e classificação dos geossítios no âmbito Internacional/Nacional ou Regional/Local pelo Método Brilha (2005).

Tabela 6.2.1.2 - a) b) e c) Valores atribuídos para cada parâmetro que compõem as categorias A, B e C do método Brilha (2005). Com destaque para o conjunto de parâmetros que classificam os geossítios no âmbito Internacional/Nacional ou Regional/Local. 
Tabela 6.2.2.1 - Resultados finais para o tipo de interesse dos geossítios (Ic, Id, It, $\mathrm{Ig}$ ), para a vulnerabilidade (V), Prioridade de Proteção (PP) e a posição de cada geossítios.

Tabela 6.2.2.2 - a) Valor atribuído a cada parâmetro que compõem a categoria Vulnerabilidade e os valor final obtido para cada geossítio a partir do cálculo da média ponderada pelo método GEOSSIT (2014)...

Tabela 6.2.2.2 - b), c), e d) Valor atribuído a cada parâmetro que compõem as categorias Características Intrínsecas, Uso Potencial e Necessidade de Proteção e os valor final para cada geossítios obtido a partir do cálculo da média aritmética. Método GEOSSIT (2014).

[147/148]

Tabela 6.2.2.3 - Resultados obtidos para (Q) relevância dos geossítios e a classificação no âmbito Regional, Nacional e Internacional pelo método GEOSSIT (2014).

Tabela 6.2.2.4 - a), b), c) Valores atribuídos aos parâmetros analisados para o cálculo de Ic, Id e It do método GEOSSIT (2014) seguidos dos resultados finais obtidos para cada geossítio.

Tabela 6.2.2.4 - d) Valores obtidos para Ic, Id e It seguidos dos resultados finais para o Índice global dos geossítio. $\mathrm{lg}=(\mathrm{Ic}+\mathrm{Id}+\mathrm{It}) / 3$.

Tabela 6.2.3.1- a) e b) Valores atribuídos para cada parâmetro e a média aritmética para as categorias: Valor Intrínseco (Vi) e Valor Científico (Vci). Método Pereira (2010).

$[150 / 151]$

Tabela 6.2.3.1- c) e d) Valores atribuídos para cada parâmetro e a média aritmética para as categorias: Valor Turístico (Vtur) e Valor de Uso/Gestão (Vug). Método Pereira (2010).

[151]

Tabela 6.2.3.2 - Resultados obtidos para o cálculo dos valores de VUC, VUT, VC e o Ranking de Relevância - R, com a respectiva posição de cada geossítio. Seguido do valor médio obtido para cada categoria. Método Pereira (2010).

[152]

Tabela 6.2.3.3 - Resultados obtidos para definição de relevância em escala local, regional, nacional e internacional. Média de $R=11,81$. Método de Pereira (2010).

[153]

\section{CAPÍTULO 7}

Tabela 7.3.1 - Geossítios inventariados em Ubatuba, o contexto geológico, principais tipos de interesse e usos potenciais.

Tabela 7.4.4.1. Comparação entre a seriação dos geossítios a partir dos resultados obtidos nos diferentes métodos de quantificação: à esquerda temos os resultados obtidos pelo método Brilha de (2005), ao centro os resultados obtidos pelo método GEOSSIT (2014) e a direita os resultados obtidos pelo método de Pereira (2010). 


\section{LISTA DE GRÁFICOS}

\section{CAPÍTULO 7}

Gráfico 7.4.4.1. a - Resultado final da quantificação dos geossítios (Q) de Ubatuba pelo método de Brilha (2005). (1) Charnockito Ubatuba, (2) Praia do Cedro do Sul, (3) Pedra do Sino de Ubatuba, (4) Praia Ponta Aguda, (5) Monzogranito Ilha Anchieta, (6) Gruta que Chora, (7) Brecha Magmática llha Anchieta, (8) Xenólitos do Manto e Cones de Explosão, (9) Pico do Corcovado e (10) Pedreira Itamambuca. [168]

Gráfico 7.4.4.1. b - Prioridade de Proteção (PP) dos geossítios pelo método GEOSSIT (2014). (1) Charnockito Ubatuba, (2) Praia do Cedro do Sul, (3) Pedra do Sino de Ubatuba, (4) Praia Ponta Aguda, (5) Monzogranito Ilha Anchieta, (6) Gruta que Chora, (7) Brecha Magmática Ilha Anchieta, (8) Xenólitos do Manto e Cones de Explosão, (9) Pico do Corcovado e (10) Pedreira Itamambuca.

[168]

Gráfico 7.4.4.1. c - Ranking de Relevância (R) dos geossítios inventariados em Ubatuba, segundo método de Pereira (2010). (1) Charnockito Ubatuba, (2) Praia do Cedro do Sul, (3) Pedra do Sino de Ubatuba, (4) Praia Ponta Aguda, (5) Monzogranito Ilha Anchieta, (6) Gruta que Chora, (7) Brecha Magmática Illha Anchieta, (8) Xenólitos do Manto e Cones de Explosão, (9) Pico do Corcovado e (10) Pedreira Itamambuca. Média de $(R)=11,81$.

[169]

Gráfico 7.4.4.2. a - Resultados parciais para a categoria A (Características Intrínsecas), segundo método de Brilha (2005); b - Resultados parciais para a categoria A (Características Intrínsecas), segundo método GEOSSIT (2014); Resultados parciais para categoria valor intrínseco (Vi) pelo método de Pereira (2010). Série 1: (1) Charnockito Ubatuba, (2) Praia do Cedro do Sul, (3) Pedra do Sino de Ubatuba, (4) Praia Ponta Aguda, (5) Monzogranito llha Anchieta, (6) Gruta que Chora, (7) Brecha Magmática Ilha Anchieta, (8) Xenólitos do Manto e Cones de Explosão, (9) Pico do Corcovado e (10) Pedreira Itamambuca. Média de Vi $=2,25$ pelo método Pereira.

[173/174]

Gráfico 7.4.4.3. a - Resultados parciais para a categoria B (Uso Potencial), segundo método de Brilha (2005); b - Resultados parciais para a categoria B (Uso Potencial), segundo método GEOSSIT (2014); (1) Charnockito Ubatuba, (2) Praia do Cedro do Sul, (3) Pedra do Sino de Ubatuba, (4) Praia Ponta Aguda, (5) Monzogranito llha Anchieta, (6) Gruta que Chora, (7) Brecha Magmática llha Anchieta, (8) Xenólitos do Manto e Cones de Explosão, (9) Pico do Corcovado e (10) Pedreira Itamambuca.

[174/175]

Gráfico 7.4.4.3. c - Resultados parciais para categoria valor de uso/gestão (Vug) pelo método de Pereira (2010). (1) Charnockito Ubatuba, (2) Praia do Cedro do Sul, (3) Pedra do Sino de Ubatuba, (4) Praia Ponta Aguda, (5) Monzogranito Ilha Anchieta, (6) Gruta que Chora, (7) Brecha Magmática llha Anchieta, (8) Xenólitos do Manto e Cones de Explosão, (9) Pico do Corcovado e (10) Pedreira Itamambuca. Médio de Vug = 2,46. [176] 
Gráfico 7.4.4.4. a - Resultados parciais para a categoria C (Necessidade de Proteção), segundo método de Brilha (2005); b - Resultados parciais para a categoria C (Necessidade de Proteção), segundo método GEOSSIT (2014). (1) Charnockito Ubatuba, (2) Praia do Cedro do Sul, (3) Pedra do Sino de Ubatuba, (4) Praia Ponta Aguda, (5) Monzogranito Ilha Anchieta, (6) Gruta que Chora, (7) Brecha Magmática Ilha Anchieta, (8) Xenólitos do Manto e Cones de Explosão, (9) Pico do Corcovado e (10) Pedreira Itamambuca.

Gráfico 7.4.4.5 - Resultados parciais para a categoria Vulnerabilidade segundo método GEOSSIT (2014). (1) Charnockito Ubatuba, (2) Praia do Cedro do Sul, (3) Pedra do Sino de Ubatuba, (4) Praia Ponta Aguda, (5) Monzogranito Ilha Anchieta, (6) Gruta que Chora, (7) Brecha Magmática Ilha Anchieta, (8) Xenólitos do Manto e Cones de Explosão, (9) Pico do Corcovado e (10) Pedreira Itamambuca.

[178]

Gráfico 7.4.4.6 a/b - Resultados parciais para as categorias Valor científico (Vci) e Valor Turístico (Vtur) segundo método de Pereira (2010). (1) Charnockito Ubatuba, (2) Praia do Cedro do Sul, (3) Pedra do Sino de Ubatuba, (4) Praia Ponta Aguda, (5) Monzogranito Ilha Anchieta, (6) Gruta que Chora, (7) Brecha Magmática Ilha Anchieta, (8) Xenólitos do Manto e Cones de Explosão, (9) Pico do Corcovado e (10) Pedreira Itamambuca. Média de Vci = 2,78 e Vtur = 1,62.

$[179 / 180]$

Gráfico 7.4.4.7 - Resultados obtidos pelo método GEOSSIT para os tipos de interesse dos geossítios. a - Interesse Científico (Ic); b - Interesse Didático (Id); c Interesse Turístico (It). Geossítios: (1) Charnockito Ubatuba, (2) Praia do Cedro do Sul, (3) Pedra do Sino de Ubatuba, (4) Praia Ponta Aguda, (5) Monzogranito Ilha Anchieta, (6) Gruta que Chora, (7) Brecha Magmática Ilha Anchieta, (8) Xenólitos do Manto e Cones de Explosão, (9) Pico do Corcovado e (10) Pedreira Itamambuca.

Gráfico 7.4.4.8a- Resultados obtidos pelo método de Pereira (2010) para o Valor de Uso Científico (VUC). Média de VUC = 2,57.

Gráfico 7.4.4.8b - Resultados obtidos pelo método de Pereira (2010) para o Valor de Uso Turístico (VUT). Média de VUT = 1,95.

Gráfico 7.4.4.8c - Resultados obtidos pelo método de Pereira (2010) para o Valor de Conservação (VC). Média de VC = 2,40. Geossítios: (1) Charnockito Ubatuba, (2) Praia do Cedro do Sul, (3) Pedra do Sino de Ubatuba, (4) Praia Ponta Aguda, (5) Monzogranito Ilha Anchieta, (6) Gruta que Chora, (7) Brecha Magmática Ilha Anchieta, (8) Xenólitos do Manto e Cones de Explosão, (9) Pico do Corcovado, (10) Pedreira Itamambuca e (11). 


\section{INTRODUÇÃO}

Os estudos que envolvem a temática da conservação da natureza cada vez mais ganha espaço na sociedade contemporânea. O aumento populacional na Terra e o desenvolvimento social e econômico resultam na crescente demanda e na multiplicação de "riscos ambientais" decorrentes da exploração dos recursos naturais, que muitas vezes chegam até os seus limites máximos.

No século $X X$, a problemática da conservação da natureza ganha um papel central na reflexão em torno das esferas sócio-políticas econômicas e ambientais assumindo um caráter diretivo no desenvolvimento da humanidade (JACOBI, 2005).

A publicação da Convenção para a Proteção do Patrimônio Mundial, Cultural e Natural (UNESCO), reunida em Paris em 1972, representa o marco no debate internacional focado nas questões ambientais (UNESCO, 2003). Seguida por diversas iniciativas durante a década de 80, atinge o seu clímax em 1992, no Rio de Janeiro com a Conferência das Nações Unidas sobre o meio ambiente - a Rio 92, quando são lançadas novas bases para o desenvolvimento e o enfoque do desenvolvimento sustentável é adotado como um marco conceitual.

No contexto de enfrentamento da crise ambiental, configurada na degradação sistemática de recursos naturais e nos impactos negativos desta degradação sobre a vida humana, surge o conceito de desenvolvimento sustentável, como ação mitigadora dos impactos ambientais causados pelo homem. Em sentido mais abrangente, remete à redefinição das relações sociedade humana - natureza. No sentido mais estrito, o desenvolvimento sustentável pode ser entendido como um processo onde as restrições mais relevantes estão relacionadas ao uso de recursos naturais e ao desenvolvimento tecnológico (JACOBI, 2005).

Apesar do conceito de desenvolvimento sustentável propor restrições quanto ao uso dos recursos naturais - que englobam os recursos minerais, a abordagem conservacionista os contempla de modo bastante utilitarista, essencialmente os aspectos da biodiversidade, esquecendo as questões relacionadas à geodiversidade.

Nesse contexto, na década de 80 do século $X X$ surgem na Europa às primeiras iniciativas dos geocientistas no que diz respeito à geoconservação, com o objetivo da preservação do patrimônio geológico e a compreensão dos processos 
naturais a eles associados, envolvendo todas as ações empreendidas na defesa da geodiversidade (LIMA, 2008).

Em 1988, foi criado o European Working Group for Earth Science Conservation, transformado em 1993 em ProGeo - European Association for the Conservation of the Geological Heritage. Em 1996, durante o $30^{\circ}$ Congresso Internacional de Geologia, surge a proposta de proteção e promoção do patrimônio geológico por meio da criação de geoparques. Em 2001 foi estabelecida a Rede Europeia de Geoparques (REG), que assina um acordo com a UNESCO e passa a ser o mecanismo de inclusão de geoparques na rede mundial (LIMA, 2008; PEREIRA, 2010).

No Brasil, de acordo com Lima (2008) a geoconservação é uma área da Geologia muito recente. Os estudos sistemáticos relacionados ao patrimônio geológico - definido como o conjunto de geossítios inventariados e caracterizado de uma região (BRILHA, 2005), bem como estudos com ênfase nas estratégias de conservação de geossítios são ainda escassos no território brasileiro. Entretanto, nas últimas décadas verifica-se um grande aumento de iniciativas ligadas à geoconservação, como por exemplo, o Projeto Monumentos Geológicos/RN, o Projeto Sítios Geológicos e Paleontológicos/PR e o Projeto Caminhos Geológicos/RJ. No estado de São Paulo, as iniciativas relacionadas aos monumentos geológicos declarados pelo Conselho Estadual de Monumentos Geológicos (CoMGeo-SP), estão a região do Parque Estadual Turístico do Alto Ribeira (PETAR), pelas cavernas e formações rochosas esculpidas pela água e a Rocha Moutonnée de Salto-SP, cuja descoberta comprovou a origem glacial das rochas a ela associadas. Além disso, houve a criação do Núcleo de Apoio à Pesquisa em Patrimônio Geológico e Geoturismo, o GeoHereditas, em 2011 e a criação da linha de pesquisa em Patrimônio Geológico Natural e Construído e Geoconservação em 2012 no Programa de Pós-Graduação em Mineralogia e Petrologia do Instituto de Geociências da Universidade de São Paulo - IGc-USP com o objetivo de sistematizar e promover pesquisa, debates e projetos de extensão sobre patrimônio geológico, geoconservação e geoturismo.

Partindo deste contexto, a presente dissertação de mestrado buscou a aplicação da estratégia de geoconservação como forma de conhecer, divulgar e proteger o patrimônio geológico do município de Ubatuba - SP. 


\subsection{Localização e Acesso}

A cidade de Ubatuba está localizada no litoral norte do estado de São Paulo (Figura 1.1.1), distante $250 \mathrm{~km}$ da capital. Limita-se ao sul com a cidade de Caraguatatuba e ao norte com Parati (Rio de Janeiro), a oeste com os municípios de Cunha, São Luiz do Paraitinga e Natividade da Serra, a leste com o Oceano Atlântico. A cidade é cortada pelo trópico de Capricórnio, achando-se a leste na latitude $23^{\circ} 26^{\prime} 21^{\prime \prime}, 45$, passando em frente a pista do aeroporto local.

A região inclui importantes Unidades de Conservação (UC), tais como o Parque Estadual da Serra do Mar, Núcleo Picinguaba, o Parque Estadual da Ilha Anchieta (PEIA) e a APA Marinha do litoral norte de São Paulo (Figura 1.1.2). Estas UC integram o Projeto de Preservação da Mata Atlântica (PPMA) e apresentam grande potencial geoturístico, pois além da rica fauna e flora, apresentam afloramentos rochosos formados em diferentes estágios evolutivos, caracterizando grande potencial didático para a comunidade científica e público leigo quanto à origem e evolução deste segmento do litoral (GARCIA \& SANTOS, $2012^{1}$ ).

1 GARCIA, M.G.M; SANTOS, P.L.A. Potencial Geoturístico das Trilhas no Parque Estadual da Ilha Anchieta, Litoral Norte de São Paulo: Geoconservação e Divulgação Científica. Relatório de Iniciação Científica, aceito pela Pró-Reitoria de Graduação da Universidade de São Paulo, 2012. 


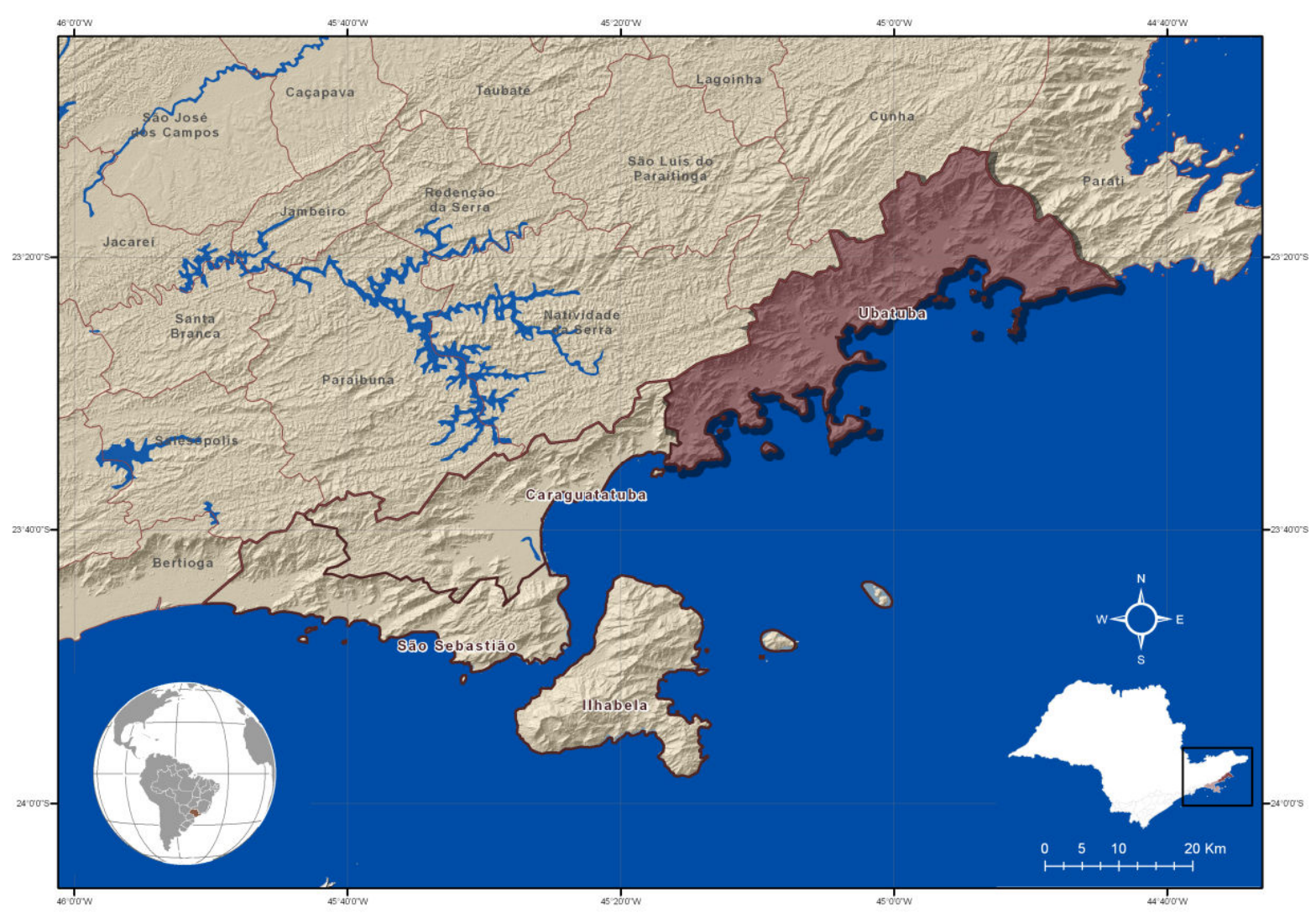

Figura 1.1.1 - Mapa de localização do Litoral Norte de São Paulo com destaque para Ubatuba. Autor: Carlos Mazoca. Fonte: Google $®$ in Arcgis.

\subsection{Objetivos e Justificativas}

O município de Ubatuba, localizado no litoral norte do estado de São Paulo, constitui um dos principais destinos turísticos da região. Neste local, são encontradas praias, costões rochosos e as escarpas da Serra do Mar encobertas pela Mata Atlântica, que constituem o ambiente genético. Muitos desses locais estão inseridos nas Unidades de Conservação: a APA Marinha do litoral norte, o Núcleo Picinguaba do Parque Estadual da Serra do Mar (PESM) e o Parque Estadual da Ilha Anchieta (PEIA) e são bastante conhecidos pela sua beleza cênica e pelas rochas das encostas que são visitadas para prática do ecoturismo e turismo de aventura. Em geral, o acesso a estes locais é feito por meio do percurso das trilhas ecoturísticas. Entretanto, devido a pouca difusão das geociências no Brasil, as informações a respeito das rochas, as formas geomorfológicas, assim como os processos que formam o ambiente genético, são pouco difundidos. 
Considerando a geodiversidade da região e o grande potencial turístico, a motivação deste trabalho surge pela necessidade de conhecer, conservar e divulgar o patrimônio geológico da região.

Em geral, o inventário e a classificação de geossítios podem ser feitos utilizando-se um contexto geológico definido (framework). No caso da região abordada, o principal aspecto de caráter geocientífico a ser considerado no que concerne aos afloramentos descritos é a amalgamação, a evolução e a fragmentação do Supercontinente Gondwana, que se constituem em eventos tectônicos importantes na história geológica da região. Neste sentido, alguns sítios geológicos da região podem ser utilizados para exemplificar a geodiversidade relacionada a estas etapas (GARCIA, 2012).

Lima (2008) sugere que o inventário do patrimônio geológico brasileiro seja feito de maneira compartimentada, sendo cada estado responsável pela identificação e gestão desse patrimônio, pois são as instituições estaduais conhecedoras das especificidades da geologia de cada estado. Nesse sentido, os resultados deste trabalho contribuirão para no inventário do patrimônio geológico do estado de São Paulo. Contribuirão ainda, na elaboração de roteiros turísticos didáticos propostos para a região.

Este trabalho tem como objetivo geral o inventário do patrimônio geológico do município de Ubatuba, litoral norte do estado de São Paulo e a proposição de estratégias de conservação para os geossítios mais relevantes. Para atingir esse objetivo foram estabelecidos como objetivos específicos:

a) Inventário do patrimônio geológico de Ubatuba, por meio da caracterização de geossítios;

b) Descrição dos geossítios;

c) Quantificação da relevância e classificação destes geossítios;

d) Elaborar propostas de geoconservação para os geossítios, integrando-a ao patrimônio cultural e a outras vertentes do patrimônio natural (biológica, por exemplo), de modo a fomentar o geoturismo na região. 


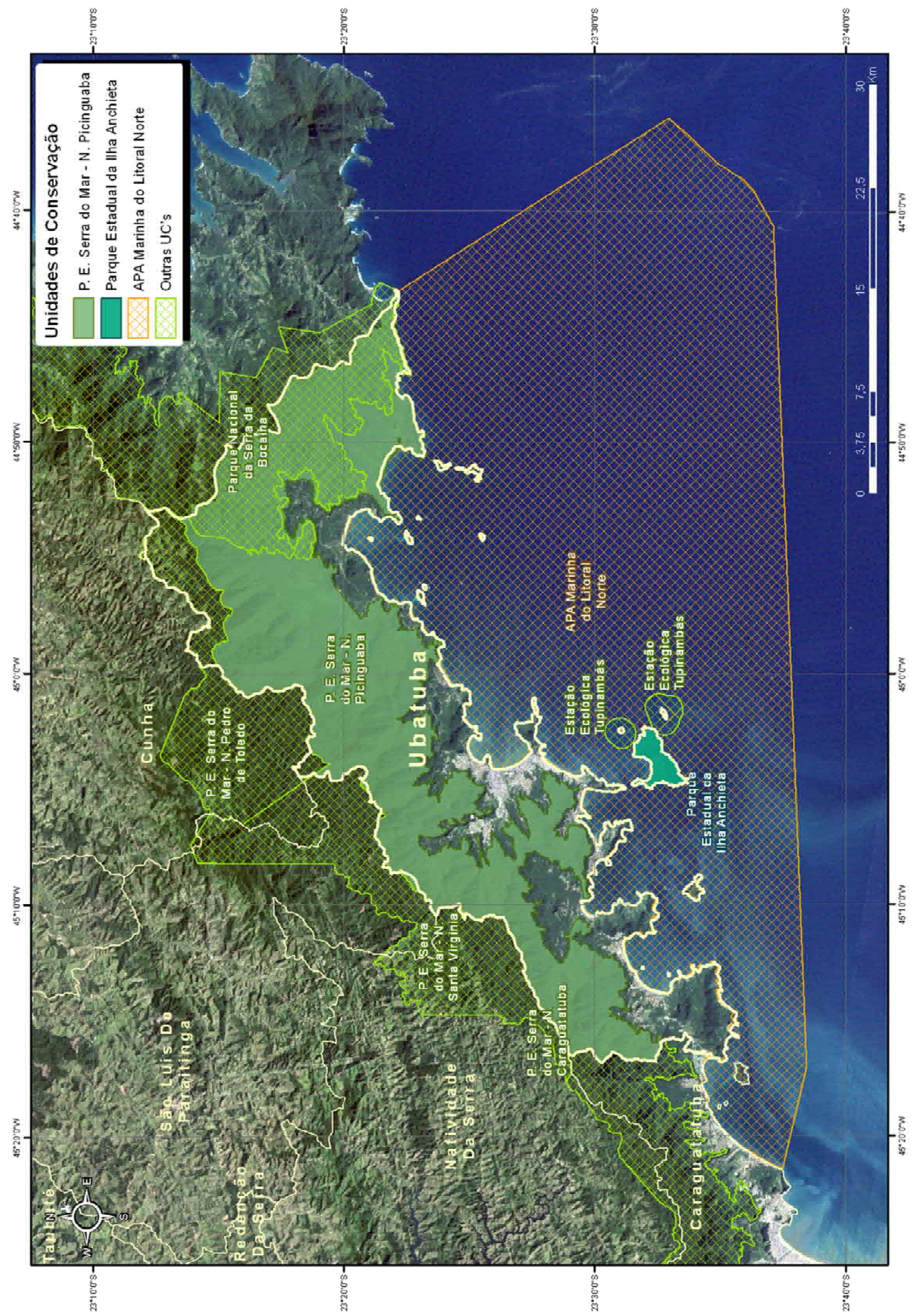

Figura 1.1.2 - Mapa das Unidades de Conservação do município de Ubatuba, com destaque para o Núcleo Picinguaba do Parque Estadual da Serra do Mar, Parque Estadual da llha Anchieta e APA Marinha do Litoral Norte. Autor: Carlos Mazoca. Fonte: Google $\AA^{\text {in }}$ Arcgis. 


\subsection{Metodologia}

A metodologia empregada para e execução deste trabalho consistiu de diferentes etapas:

\subsubsection{Levantamento bibliográfico}

Nesta etapa, foi realizado de maneira detalhada um levantamento das referências bibliográficas sobre a região no âmbito, principalmente, da geologia para a identificação dos geossítios de maneira mais direcionada. Além disso, por meio de comunicação oral com os professores e colegas de pós-graduação do Instituto de Geociências foram pesquisados pontos de interesse geológico utilizados em aulas de campo para os cursos de graduação e pontos objeto de outras pesquisas. Durante esta etapa foram listados os afloramentos que, potencialmente, poderiam ser caraterizados como geossítios e inicialmente se tornaram alvos dos trabalhos de campo.

Esta etapa incluiu ainda um levantamento de referências sobre os conceitos de geodiversidade, geossítio, patrimônio geológico e geoconservação e sobre os aspectos históricos e culturais da região.

Finalmente, foi realizada uma pesquisa no âmbito legal sobre criação e gestão das áreas protegidas do estado de São Paulo.

\subsubsection{Trabalhos de campo}

Esta etapa foi divida em cinco saídas de campo: em dezembro de 2012, maio, junho, setembro de 2013 e abril de 2014. Foram visitados os geossítios descritos preliminarmente em trabalhos anteriores do grupo de pesquisa GeoHereditas, realizado o mapeamento dos pontos destacados durante o levantamento bibliográfico e outros pontos que foram sugeridos em comunicação oral com os moradores da região e funcionários das Unidades de Conservação.

O acesso aos afloramentos foi realizado principalmente pelo percurso das trilhas ecoturísticas de Ubatuba, quando necessário com o acompanhamento dos monitores ambientais do Núcleo Picinguaba do Parque Estadual da Serra do Mar e do Parque Estadual da Ilha Anchieta. 
Durante os trabalhos de campo foram feitas as descrições dos afloramentos em relação aos seus aspectos estruturais e dos principais litotipos. Os geossítios foram georreferenciados com o auxílio de um GPS (Global Positioning System) Garmin e amostras foram retiradas para análises posteriores.

Esta etapa resultou em cinquenta e nove pontos de paradas ao longo do percurso de dez trilhas ecoturísticas dentro e fora dos Parques Estaduais, trinta e um pontos livres - pontos fora de trilhas, totalizando noventa pontos. Destes pontos dez foram destacados como geossítios. A localização e o traçados das trilhas foram incorporados no banco de dados do GeoHereditas.

As amostras coletadas foram sistematicamente separadas e identificadas, posteriormente foram alvo de descrição petrográfica detalhada pelo discente Fábio Pileggi integrante do Projeto de Iniciação Científica "Banco de dados petrográficos dos Geossítios do Litoral Norte do estado de São Paulo" junto ao Núcleo de Apoio à Pesquisa ao Patrimônio Geológico e Geoturismo - GeoHereditas.

\subsubsection{Descrição dos Geossítios}

Os geossítios foram sumariamente descritos baseando-se nas observações de campo e revisão bibliográfica. Optou-se pela elaboração de um modelo descritivo que sistematizou tais informações da seguinte maneira: dados de localização e acesso, tipo de local (ponto, área ou seção), dimensão, unidade no mapa da CPRM (2006), justificativas do valor científico, elementos de interesse, uso potencial de cada geossítio e as informações dos tipos litológicos observados em campo.

\subsubsection{Integração dos dados}

A metodologia adotada para a conservação do patrimônio geológico de Ubatuba foi sistematizada por Brilha (2005). Esta metodologia agrupa uma série de etapas sequenciais como estratégias de geoconservação, que incluem: inventário, quantificação, classificação, conservação, valorização e divulgação e monitoramento. No Brasil, o Serviço Geológico do Brasil (CPRM) criou recentemente - GEOSSIT, um sistema de cadastramento e quantificação de Geossítios que consiste de um aplicativo disponível para a proposição de novos locais de interesse geológico. A ficha de inventário que serviu como base para este aplicativo foi 
desenvolvida pela Associação Europeia para a Conservação do Patrimônio Geológico - ProGeo (1992) e apresentada inicialmente por Brilha (2005), baseada e modificada do trabalho de Uceda (2000). Adicionada de parâmetros adaptados da metodologia proposta por Garcia-Cortés \& Urquí (2009) para o inventário nacional da Espanha.

Durante esta etapa foram avaliados de forma crítica os critérios de inventário, quantificação e classificação de geossítios. Optou-se pelo uso do método desenvolvido por Brilha (2005), pelo teste do aplicativo GEOSSIT e pelo método de Pereira (2010). Os critérios adotados foram consequentemente adaptados para a região de estudo.

Posteriormente, baseando-se nos resultados da quantificação foram elaboradas propostas para a valorização e divulgação para os geossítios mais relevantes.

\subsection{Estrutura da Dissertação}

O presente trabalho foi estruturado em sete capítulos. A presente introdução (capítulo 1) que se refere à apresentação do tema, os objetivos e justificativas, seguidos da metodologia de trabalho.

No capítulo 2 apresentam-se a contextualização teórica e a revisão de conceitos sobre temática da geodiversidade, patrimônio geológico e geoconservação. Logo, apresenta-se o contexto sobre as Unidades de Conservação (UC) no Brasil e as áreas protegidas no município de Ubatuba - SP (capítulo 3).

O capítulo 4 foca a geodiversidade da cidade de Ubatuba, por meio de sua caracterização geral e contexto geológico da região baseadas na compilação da bibliografia consultada.

Seguem-se o capítulo 5, apresentando o inventário do patrimônio geológico de Ubatuba com a descrição e caracterização dos geossítios destacados para a região. O capítulo 6 que foca a quantificação dos geossítios e os resultados obtidos. Finalmente, o capítulo 7 apresenta a discussão e as conclusões obtidas com a realização do trabalho. 


\section{CAPÍTULO 2. GEODIVERSIDADE PATRIMÔNIO GEOLÓGICO E GEOCONSERVAÇÃO}

\subsection{Geodiversidade: conceitos e valores}

A aplicação do termo geodiversidade, segundo Brilha (2005) é relativamente recente. Gray (2008) afirma que termo surgiu por ocasião da Conferência de Malvern sobre a Conservação Geológica e Paisagística, realizada em 1993 no Reino Unido. Alguns autores sugerem que a aplicação do termo aparece contrapondo o conceito de biodiversidade, que inicialmente considera apenas a diversidade biológica e não a variação dos elementos não vivos - abióticos. (SERRANO CAÑADAS \& RUYZ FLAÑO, 2007; MANOSSO, 2009). Assim como o conceito de biodiversidade, passa a evoluir a partir da Convenção da Biodiversidade, realizada durante a Conferência Mundial Rio-92 (GRAY, 2008).

Segundo a Royal Society of Wildlife Trusts do Reino Unido, a geodiversidade consiste na variedade de ambientes geológicos, fenômenos e processos que dão origem às paisagens, rochas, minerais, fósseis e solos, que são o suporte para a vida na Terra. Essa definição também é adotada por Brilha (2005) e Gray (2004).

Para Dixon ${ }^{2}$ et al. (1997) e Eberhard ${ }^{3}$ (1997), citados por Pereira (2010 p.15) a geodiversidade é definida como

A diversidade de elementos geológicos, geomorfológicos e edáficos que evidenciam a história da Terra, sugerindo a inclusão dos processos paleobiológicos ou paleoambientais, que têm lugar na atualidade, dentro do escopo deste conceito.

Dentre as definições mais usadas para o conceito está a definição de Sharples (2002) que entende o termo como gama (ou diversidade) de arranjos, processos e sistemas geológicos (substrato), geomorfológicos (formas da paisagem) e pedológicos, dotados de valores intrínsecos, ecológicos e antropocêntricos. Num

\footnotetext{
2 Dixon, G., Sharples, C., Houshold, I., Pemberton, M., \& Eberhard, R. -1997- Conservation Management Guidelines for Geodiversity. Unpublished Report to the Tasmanian Regional Forest Agreement Environment and Heritage Technical Committee, April 1997, 70 p.

${ }^{3}$ Eberhard, R., -1997- Pattern and Process: Towards a Regional Aprproach to National Estate Assessment of Geodiversity. Technical Series $n^{\circ} 2$, Australian Heritage commission \& Environment Forest Taskforce, Environment Australia- Canberra.
} 
sentido mais amplo, integrando os elementos da biodiversidade e geodiversidade está à definição de Nieto (2001)

\begin{abstract}
A Geodiversidade consiste no número e variedade de estruturas (sedimentares, tectônicas, geomorfológicas, hidrogeológicas e petrológicas) e de materiais geológicos (minerais, rochas, fósseis e solos), que constituem o substrato físico e natural de uma região, sobre o qual se assenta a atividade orgânica, incluindo-se a antrópica.
\end{abstract}

Em 2004, Kozlowski define a geodiversidade como a variedade natural da superfície terrestre, envolvendo os seus aspectos geológicos e geomorfológicos, solos, águas superficiais, bem como todos os demais sistemas resultantes de processos naturais (endógenos e exógenos) e antrópicos.

Stanley (2004) entende o termo como a variedade de ambientes geológicos, fenômenos e processos ativos que dão origem a paisagens, rochas, minerais, fósseis, solos e outros depósitos superficiais que são o suporte para a vida na Terra.

No Brasil, o termo foi introduzido e fomentado principalmente pelo crescimento do geoturismo, por iniciativas do Serviço Geológico do Brasil - CPRM, que em 2006 lança o "Mapa Geodiversidade do Brasil”, escala: 1:2.500.000, onde define a geodiversidade como

Natureza abiótica (meio físico) constituída por uma variedade de ambientes, fenômenos e processos geológicos que dão origem às paisagens, rochas, minerais, solos, águas, fósseis e outros depósitos superficiais que propiciam o desenvolvimento da vida na Terra, tendo como valores intrínsecos a cultura, o estético, o econômico, o científico, o educativo e o turístico.

Por ultimo, Serrano \& Ruiz Flaño (2007) partindo de uma visão mais integradora definem a geodiversidade como:

A variabilidade da natureza abiótica, incluídos os elementos litológicos, tectônicos, geomorfológicos, edáficos, hidrológicos, topográficos e processos físicos sobre a superfície terrestre os mares 
e oceanos, junto a sistemas gerados por processos naturais endógenos e exógenos e antrópicos, quem compreende a diversidade de partículas elementos e lugares.

Considerando que a geodiversidade é constituída pelos fatores abióticos, a variedade de ambientes geológicos e processos ativos que dão origem a paisagens, rochas, minerais, fósseis, solos e outros depósitos, sendo resultado da lenta evolução da Terra desde o surgimento do planeta, os conceitos acima evidenciam um caráter bastante funcional dos elementos da geodiversidade enquanto suporte a vida.

Entretanto, concorda-se com Manosso (2009) que a geodiversidade pode abarcar informações importantes sobre a evolução e formação do planeta. Nesse sentido, Pereira (2010) define a geodiversidade como:

\begin{abstract}
Conjunto de elementos abióticos do planeta Terra, incluindo os processos físico-químicos associados, materializados na forma de relevos (conjunto de geoformas), rochas, minerais, fósseis e solos, formados a partir das interações entre os processos das dinâmicas interna e externa do planeta e que são dotados de valor intrínseco, científico, turístico e de uso/ gestão.
\end{abstract}

Nessa conjuntura o presente trabalho se fundamenta, adotando como conceito de geodiversidade o proposto pelo Serviço Geológico do Brasil em 2006.

Segundo Brilha (2005) a geodiversidade possui um conjunto de valores os quais fundamentam a necessidade de proteção:

Valor intrínseco: o mais subjetivo e difícil de quantificar, pois está muito ligado às perspectivas religiosas de cada sociedade e cultura.

Valor cultural: é conferido pelo homem quando se reconhece uma forte interdependência entre o seu desenvolvimento social, cultural, religioso e o meio físico que o rodeia. Historicamente os fenômenos geológicos estão ligados diretamente no modo de vida das antigas civilizações, tanto pela escolha dos materiais usados para a construção de casas e utensílios (como pontas de flechas, 
lâminas para machados), quanto para determinar o próprio local onde viviam (abrigos rochosos, cavernas). O modo de vida nas sociedades modernas também é determinado pelos elementos da geodiversidade, a disposição estratégica de algumas cidades em função da sua geologia e geomorfologia, e disponibilidade de recursos naturais, como Ouro Preto, Minas Gerais. Em algumas cidades como Ubatuba - São Paulo, os elementos da geodiversidade estão ligados diretamente na cultura local, caiçara e quilombola, pois é fonte da matéria prima para o artesanato e para a alimentação dos moradores da região.

Valor estético: é também um valor subjetivo que não pode ser quantificado, pois a referência de "beleza da paisagem" é distinta para cada observador. Mas de certa maneira as paisagens naturais apresentam algum tipo de valor estético que pode ser evidenciado pelas feições geológicas e geomorfológicas de um local, por exemplo.

Valor econômico: refere-se ao valor de uso dos recursos naturais usados pelo homem, em especial os materiais geológicos, como minerais e rochas que são usados na construção civil e na produção de energia. Este valor é mais objetivo e compensável.

Valor funcional: visto sob duas perspectivas, este valor refere-se ao uso da geodiversidade in situ de caráter utilitário pelo homem como a construção de barragens, estradas, e no armazenamento de reservas como a água subterrânea, reservas minerais. O valor da geodiversidade como substrato como suporte dos sistemas físicos e a vida, que é conferido pela interdependência do meio abiótico e biótico.

Valor científico e educativo: os estudos no campo das geociências têm na geodiversidade suas amostras mais representativas que contribuem para conhecimento e interpretação dos registros que contam a história do Planeta Terra. Oferecem bases para a investigação dos processos ativos que configuram as paisagens e ajudam a controlar situações em áreas de risco, como deslizamentos, áreas de vulcanismo e tectonismo. Finalmente, por meio dos registros geológicos os geocientistas podem observar e aprender de maneira prática os processos que condicionaram a evolução do nosso planeta enriquecendo a sua formação, bem como conhecer a necessidade de conservar e proteger esse patrimônio. 
Do mesmo modo que são atribuídos os diversos valores à geodiversidade, são também atribuídos os riscos que a ameaçam. Brilha (2005) fundamentado no trabalho de Gray (2004) destaca que a maior parte dessas ameaças são resultantes direta ou indiretamente da atividade humana. Estas se assemelham as mesmas ameaças à biodiversidade.

O desenvolvimento das cidades e o aumento populacional resultaram na crescente demanda por recursos naturais para atender a necessidade humana na produção de energia, alimentos e lazer. Neste sentido, as ameaças à geodiversidade referem-se principalmente às atividades de exploração dos recursos minerais, ao desenvolvimento de estruturas obras como rodovias e ferrovias, à gestão de bacias hidrográficas, reflorestamento e agricultura, atividades militares, atividades recreativas e turísticas, a coleta de amostras para fins não científicos e o não conhecimento das Ciências da Terra pelos governos, técnicos, e público em geral (BRILHA, 2005).

\subsection{Patrimônio Geológico e Geoconservação}

Do mesmo modo que o conceito de geodiversidade vem ganhando espaço nas discussões sobre a conservação da natureza, as questões relacionadas ao patrimônio geológico e geoconservação vêm ganhando visibilidade. Entretanto, essa temática é bastante recente. Alguns autores, nas últimas décadas tem abordado 0 tema em seus trabalhos na tentativa de sistematizar, discutir e propor estratégias de geoconservação.

Para Brilha (2005) a geoconservação tem como objetivo geral a utilização e gestão da geodiversidade de maneira sustentável, englobando os recursos geológicos. Do ponto de vista mais restrito, a conservação de elementos pontuais da geodiversidade, que evidenciam um valor que se sobreponha à média. Alguns locais de interesse geológico apresentam valor singular, como científico, pedagógico, turístico, cultural, dentre outros. Estes locais, de ocorrência de um ou mais elementos da geodiversidade (aflorantes, quer como resultado da ação de processos naturais quer devido à ação humana), bem delimitados geograficamente, que apresente valor singular, são definidos como geossítios. Assim, o conjunto de 15 
geossítios inventariados e caracterizados de uma dada região constitui o patrimônio geológico.

Carcavilla et al. (2008) entende o patrimônio geológico como o conjunto de elementos geológicos que se destacam por seu valor científico, cultural ou educativo.

Ruchkys (2007) define o patrimônio geológico como um recurso documental de caráter científico, de conteúdo importante para o conhecimento e estudo da evolução dos processos geológicos e que constitui o registro da totalidade da evolução do planeta.

De acordo com Liccardo et al. (2008) o patrimônio geológico é constituído por geossítios e é um recurso natural em constante processo de transformação pelos processos geológicos, que deve ser preservado. No entanto, a ideia de preservação historicamente é atrelada e bastante difundida no que diz respeito à preservação da biodiversidade, não lembrando que esta apresenta um paralelo com a geodiversidade, que constitui o suporte a vida.

Sharples (2002 p.2) define a geoconservação como a conservação da diversidade de feições geológicas, geomorfológicas e pedológicas, mantendo a evolução natural desses e processos, em função dos seus valores intrínsecos e patrimoniais. O mesmo autor entende a geodiversidade como fator essencial a vida, que influencia de maneira direta a dinâmica da biodiversidade. Mochiutti (2009) em compilação aos dados do mesmo autor destaca que os principais objetivos da geoconservação: conservar e assegurar a manutenção da geodiversidade, proteger e manter a integridade de locais cuja geodiversidade seja relevante, minimizar os impactos adversos sobre locais onde a geodiversidade possua relevância acima da média, interpretar a geodiversidade para os visitantes de áreas protegidas, e contribuir para a manutenção da biodiversidade e dos processos ecológicos.

Carcavilla et al. (2008) apresenta os métodos de estudo adotados por diversos autores como Serrano \& Ruiz Flaño, 2007 e Kozlowski, 2004 na tentativa de aplicar os conceitos e classificar a geodiversidade. Brilha (2005) ressalta a necessidade de se estabelecer estratégias de geoconservação de modo a garantir a conservação e gestão dos geossítios. Contudo, como não é possível proteger toda a 
geodiversidade, a geoconservação deve ser concretizada após o trabalho de definição do patrimônio geológico, da sua caracterização e da quantificação do seu interesse, da análise de relevância e vulnerabilidade. Além disso, o estabelecimento de leis para a proteção da geodiversidade, a padronização de conceitos e terminologias, o desenvolvimentos de mapas da geodiversidade são dentre outras algumas ações que devem ser intensificas para garantir a proteção da geodiversidade (KOZOLOWSKI, 2004; LIMA, 2008).

\subsubsection{Estratégias de Geoconservação}

Segundo Brilha (2005) as estratégias de geoconservação consistem em uma metodologia a fim de sistematizar os trabalhos no âmbito da conservação do patrimônio geológico de uma determinada região (país, estado, cidades, área,...). Esta metodologia é agrupada em diversas etapas sequenciais: inventariação, quantificação, classificação, conservação e valorização, divulgação e monitorização. Pode ainda, ser adaptada de acordo com a realidade do local de estudo, como abordado por Lima (2008) que apresenta em seu trabalho uma proposta metodológica para o inventário do patrimônio geológico brasileiro, tomando como base a metodologia sistematizada pelo mesmo autor.

\subsubsection{Etapa de inventário}

O inventário dos geossítios é a primeira etapa de uma estratégia de geoconservação. A identificação e seleção dos geossítios devem ser feitas baseadas em objetivos pré-definidos, de maneira sistemática em todo o território estudado, baseados em estudos prévios sobre a geodiversidade. Durante o reconhecimento da área os geossítios devem ser mapeados com o auxilio de um GPS e marcados em cartas topográficas e/ou geológicas. A fim de sistematizar e facilitar o inventário, Brilha (2005) sugere o uso de uma ficha de inventário que reúna todas as informações sobre os geossítios, possibilitando posteriormente melhor tratamento dos dados. 


\subsubsection{Etapa de quantificação}

A quantificação de relevância dos geossítios pode ser feita a partir da integração de critérios dos geossítios que levam em conta as suas características intrínsecas, o uso potencial e o nível de proteção necessário para cada um deles. Esta é a quantificação numérica. Alguns autores optam pela quantificação de maneira relativa, baseada na opinião de especialistas que conheçam a região ou o próprio geossítio. Brilha (2005) afirma que ambos os métodos necessitam de mais trabalhos de investigação já que não existe um consenso entre os especialistas. Sugere ainda, o uso da quantificação numérica visando diminuir a subjetividade inerente ao processo de quantificação.

\subsubsection{Etapa de classificação}

Seguido o processo de quantificação, os geossítios que obtiverem maior relevância devem ser classificados de acordo com o enquadramento legal existente no âmbito Nacional, Estadual e Municipal. No entanto, tendo em vista as burocracias e leis que protegem preferencialmente a biodiversidade de cada região (país, estado, cidade, etc.) essa nem sempre é uma tarefa possível. Assim, os geossítios que já estão inseridos em áreas protegidas, poderão ser salvaguardados mais facilmente por estarem abarcados em leis específicas de proteção criadas para as unidades de conservação. Lima (2008) sugere alternativas como o desenvolvimento de ações de educação ambiental na contribuição da disseminação do conhecimento da área e a importância de preservar o patrimônio geológico.

\subsubsection{Etapa de conservação}

A conservação dos geossítios requer, muitas vezes, o desenvolvimento de algum tipo de intervenção para salvaguardar as propriedades físicas do geossítio e, ao mesmo tempo garantir que o mesmo seja acessível ao público de acordo com o seu interesse turístico, pedagógico, científico, ou outros. Em alguns casos, a retirada e exposição de materiais geológicos podem ser justificadas pela vulnerabilidade em 
que se encontram, como os agentes do intemperismo e processos erosivos (BRILHA, 2005).

\subsubsection{Etapa de Valorização e divulgação do patrimônio geológico}

Os geossítios que apresentarem baixa vulnerabilidade e melhores condições de observação são os que melhor se adaptam a valorização e divulgação. Estes podem ser integrados a roteiros geoturísticos, a atividades de educação ambiental e divulgação geocientífica. Além disso, podem ser valorizados por meio de folhetos, painéis interpretativos, websites, dentre outros meios de comunicação (BRILHA, 2005). Cabe ressaltar o cuidado que se deve ter na utilização de certos meios de comunicação e a maneira como as informações serão transmitidas para o tipo de público que se quer alcançar. Um exemplo clássico é a adequação da "linguagem geológica" para os turistas em geral e para o público infantil, que muitas vezes não tem o conhecimento geocientífico necessário para compreender determinados processos de formação e evolução geológica.

\subsubsection{Etapa de monitoramento}

O monitoramento é a ultima etapa da estratégia de geoconservação. Nesta etapa os geossítios deverão ser monitorados periodicamente a fim de verificar e analisar o seu estado de evolução de conservação. Algumas vezes os geossítios poderão passar períodos de visitação interrompida quando necessária à manutenção de acesso como no caso de manutenção de trilhas, ou até mesmo se apresentar novos riscos a sua integridade física resultantes de processos naturais ou antrópicos. Portanto, essa etapa torna-se não menos importante que as anteriores, pois, se trata de uma ferramenta de controle para a conservação do patrimônio geológico. 


\subsection{Panorama internacional das estratégias de Geoconservação}

As primeiras ações internacionais que marcam a preocupação com os temas ligados à geoconservação, se iniciam na década de 70 com a Convenção para a Proteção do Patrimônio Mundial, Natural e Cultural da UNESCO aprovada em Paris 1972 (UNESCO, 1972). O $2^{\circ}$ artigo considera como patrimônio natural:

Os monumentos naturais constituídos por formações físicas e biológicas ou por grupos de tais formações com valor universal excepcional do ponto de vista estético ou científico; as formações geológicas e fisiográficas e as zonas estritamente delimitadas que constituem habitat de espécies animais e vegetais ameaçados, com valor universal excepcional do ponto de vista da ciência ou da conservação; os locais de interesse naturais ou zonas naturais estritamente delimitadas, com valor universal excepcional do ponto de vista a ciência, conservação ou beleza natural.

$\mathrm{Na}$ ocasião foi criado o Comitê do Patrimônio Mundial, responsável pela gestão da Convenção do Patrimônio Mundial. Cada Estado membro é responsável por apresentar um inventário do patrimônio cultural e natural situado no seu território, que poderão ser incluídos na Lista do Patrimônio Mundial da UNESCO. Assim, os locais listados poderão ser favorecidos com investimentos turísticos e no envolvimento das comunidades locais, que desempenham um papel fundamental para conservação do patrimônio. (LIMA, 2008).

A União Internacional de Ciências Geológicas (IUGS) em 1996 lança o Projeto Global Geosites a fim de realizar um inventário do patrimônio geológico internacional, denominado "Global Geosites" e integrar sítios geológicos a lista do Patrimônio Mundial da UNESCO. Este projeto é realizado na Europa através da ProGEO (The European Association for the Conservation of the Geological Heritage), Associação Europeia para a Conservação do Patrimônio Geológico, criada em 1992 com o principal objetivo de promover ações em todo o território europeu para a proteção do patrimônio geológico - geoconservação. Essas ações são promovidas por meio de grupos nacionais de trabalhos que atuam em seus territórios locais, dentre eles estão ProGEO - Portugal, ProGEO - Espanha, 
ProGEO - Turquia, ProGEO - Noruega, ProGEO - Itália e ProGEO - sede, na Suécia (LIMA, 2008; MEDINA, 2012).

A criação da ProGEO e o seu modo de operação, de acordo com Lima (2008) é provavelmente o principal motivo para que os estudos relacionados a geoconservação sejam mais avançados na Europa. A mesma autora reflexiona que todos os países europeus, estimulados pela ProGEO, intercambiam ideias e informações, desenvolvem trabalhos com o objetivo de formar uma listagem europeia de geossítios com valor cientifico.

No ano 2000, foi criada a Rede Europeia de Geoparques (REG). Os países fundadores Alemanha, França, Grécia e Espanha destacaram como principal objetivo de cooperação entre si nas ações de geoconservação, no desenvolvimento sustentável e contribuir em estudos e desenvolvimento de informações técnicas. A REG é dirigida por um comitê de coordenação, formado por um representante de cada Geoparque e um representante da UNESCO, instituição patrocinadora a partir de 2001, quando foi firmado um acordo oficial de colaboração.

Em 2004, reunidos em Paris, um grupo de pesquisadores da comunidade cientifica junto às instituições: International Geosciense Programme (IGCP), International Geographical Union (IGU) e a International Union of Geological Sciences (IUGS) estabeleceram a Rede global de Geoparques da UNESCO e as suas diretrizes operativas. Na ocasião, foi sugerida a criação de um gabinete para a coordenação da rede com sede no Ministério da Terra e Recursos, em Pequim (China). Os geoparques existentes na REG foram automaticamente inseridos na rede Global. A Divisão de Ciências da Terra da UNESCO encarregou-se de estabelecer critérios e regulamentos para a integração de novos geoparques nacionais na Rede Global da UNESCO (PEREIRA, 2010; MEDINA 2012).

Para a UNESCO um geoparque consiste em um "território com limites bem definidos com uma área suficientemente grande para servir de apoio ao desenvolvimento socioeconômico local. Deve abranger um determinado número de geossítios em especial relevância científica, raridade e beleza, que represente a história geológica de uma determinada região. Poderá incluir ainda os significados culturais, arqueológicos, históricos e ecológicos" (BRILHA, 2005). Embora este seja um conceito bastante recente, nas últimas décadas aliado a outras estratégias, 0 21 
conceito de geoparque vem contribuindo fortemente em todo o mundo para a proteção e conservação do patrimônio geológico. Como exemplos seguem-se algumas iniciativas em Portugal, Espanha, na América Latina, em especial no Brasil.

$\mathrm{Na}$ Espanha as primeiras iniciativas de conservação são iniciadas pelo Instituto Geológico e Mineiro (IGME) quando começam diversos trabalhos, a partir de 1978, para o Inventário Nacional de Pontos de Interesse Geológico (PIGs). Em 1996, o território espanhol contava com 545 PIGs. A partir de então, ganham destaque as iniciativas para a divulgação da temática da geoconservação para os governos, instituições de ensino e empresas. Mais recentemente, em 2010 foi publicado pelo IGME o guia da geodiversidade espanhola. Os PIGs, apresentados no livro foram selecionados a partir dos trabalhos realizados pela IUGS (MEDINA, 2012). Além disso, no território espanhol existem oito geoparques ligados a Rede Global: Basque Coast Geopark, Cabo de Gata-Nijar, Central Catalonia Global Geopark, Maestrazgo Cultural Park, Sierra Norte di Servilla Geopark, Sierras Subbeticas Geopark, Sobrarbe Geopark, Villuercas-ibores-jara Geopark. Estes geoparques promovem ações de geoconservação por meio do geoturismo e educação ambiental.

Em Portugal, os trabalhos sobre a geoconservação foram iniciados em 2001 com a identificação de 14 categorias temáticas (frameworks) de relevância internacional, que mais tarde vieram a contribuir para inventário do patrimônio geológico português. Em 2007, foi criado o projeto "Identificação, caracterização e conservação do patrimônio geológico: uma estratégia de geoconservação para Portugal" idealizado pelo Centro de Ciências da Terra da Universidade do Minho que conta com a participação de outras dez universidades e com a Associação Portuguesa de Geomorfólogos. O grupo de pesquisadores envolvidos no projeto destacou 27 categorias temáticas as quais serão inseridas os geossítios de relevância internacional e nacional que melhor representam a geodiversidade do país (BRILHA ${ }^{4}, 2010$ apud MEDINA, 2012).

\footnotetext{
${ }^{4}$ BRILHA, J. (2010). Enquadramento Legal De Suporte á Protecção do Património Geológico em Portugal. En: J.M. Cotelo Neiva, António Ribeiro, Mendes Victor, Fernando Noronha, Magalhães Ramalho (Eds.), Ciências Geológicas: Ensino, Investigação e sua História Volume II Geologia Aplicada (p. 443- 450). Braga, Portugal: Associação Portuguesa de Geólogos Sociedade Geológica de Portugal.
} 
Atualmente, em Portugal são três geoparques reconhecidos pela Rede Global: Arouca Geopark, considerado de relevância internacional com destaque para as trilobitas gigantes de canelas e as "pedras parideiras" (AROUCA, 2014). O Naturtejo Geopark, que ao longo de suas quatro rotas contam a história geológica de 600 milhões de anos, desenvolve programas de educação como o "Geonaturescola" promovendo o ensino de geociências em atividades práticas no território do Geopark (NATURTEJO, 2014). O mais recente Geopark de Portugal está localizado no arquipélago de Açores, formado por nove ilhas, os geossítios ali encontrados estão dispersos pelas ilhas e zona marinha que o envolve, remetem a história geológica eruptiva do arquipélago (AÇORES, 2014). Ainda em Portugal, existe uma proposta submetida ao Comitê da UNESCO para o Geoparque "Terra de Cavaleiros" do Município de Macedo de Cavaleiros, que abrange a região do maciço de Morais, conhecida pelos geólogos portugueses como "umbigo da Terra", que apresenta vestígios de dois continentes e de um oceano desaparecidos e envolvidos na formação daquela cadeia de montanhas, há mais de 280 milhões de anos (PUBLICO PT, 2014).

Na América Latina, de modo geral, a temática da geoconservação é muito recente. Porém, países como Argentina, Chile, Uruguai e Venezuela vêm ampliando as discussões sobre a geoconservação, promovendo encontros, apresentando trabalhos e submetendo propostas de novos geoparques.

No Uruguai, em 2006 foi firmado um acordo de cooperação pela Faculdade de Ciências da Universidade da República e a prefeitura de Flores a fim de valorizar os estudos científicos e apresentar uma proposta de geoparque na região conhecida como "Gruta del Palacio". O Geoparque está localizado a cerca de 200km de Montevidéu e dentre os seus principais atrativos estão as grutas, resultantes de processos de erosão hídrica, compostas de arenitos ferrificados de cor vermelho tijolo, que resistiram processos erosivos desde milhares de anos (MEDINA, 2012).

$\mathrm{Na}$ Venezuela, em Abril de 2007 foi criada a Fundação Geoparques com o objetivo de investigar e divulgar o conhecimento geocientífico. Desde então foram realizados diversos trabalhos sobre o patrimônio geológico e geoconservação junto às comunidades locais. Em 2009 foi realizado o $1^{\circ}$ Congresso Latino americano sobre Iniciativas em Geoturismo, mesmo ano que foi gerado um documento que 
explicita a necessidade de criar uma Rede Latino-americana e do Caribe de Geoparques (MEDINA, 2012; GRUTAS DEL PALACIO GEOPARK, 2014). Ainda, em 2010 foi realizado na cidade de Mérida o Congresso Nacional de Geoturismo.

O Serviço Nacional de Geologia Mineira (SERNAGEOMIN) junto à Corporação Nacional Florestal e o Governo Regional de Araucanía do Chile, em 2013 apresentou a candidatura do primeiro Geoparque chileno a Rede Mundial. O Geoparque Kutralcura está localizado ao redor do vulcão Llaima e ao Parque Nacional Conguillío, na região da Cordilheira de Araucanía e pretende conservar o "patrimônio geológico por meio do geoturismo", fomentando as iniciativas turísticas já existentes na região e por meio da educação em geociências. Além disso, pretende-se incentivar o desenvolvimento econômico local com a criação de empregos e valorização dos produtos fabricados pelos habitantes locais (UNESCO, 2014).

Ainda no ano de 2013 a Argentina promoveu o I Simpósio Argentino de Patrimônio Geológico, Geoparques e Geoturismo e o III Encontro Latino-americano de Geoparques realizado em setembro, em San Martín de los Andes, Neuquén.

\subsection{Panorama nacional das estratégias de Geoconservação}

Lima (2008) reflexiona que no Brasil, os estudos sistematizados teóricos e práticos que abordam a temática do patrimônio geológico e geoconservação ainda são muito poucos. Contudo, nas últimas décadas nota-se a criação e desenvolvimento de muitas iniciativas que promovem a geoconservação por meio da valorização e divulgação das geociências.

Comparado aos demais países da América Latina, o Brasil, é o país pioneiro nos trabalhos relacionados à proteção do patrimônio geológico. No ano de 1997, foi criada a Comissão Brasileira dos Sítios Geológicos e Paleobiológicos - SIGEP, com os principais objetivos a identificação de sítios geológicos e a indicação dos mesmos ao programa Geosites; o gerenciamento do banco de dados nacional dos sítios de interesse geológico e a promoção de ações de conservação para os locais que 
apresentam maior vulnerabilidade (LIMA, 2008). Até o momento, os resultados obtidos foram publicados em dois livros técnicos - o primeiro volume com 58 sítios e o segundo com 40 sítios geológicos - chamados de "Sítios Geológicos e Paleontológicos do Brasil".

O Serviço Geológico do Brasil - CPRM lançou o programa "Geoecoturismo", que prevê a caracterização física de geossítios com interesse ecoturisticos, a fim de estimular novos seguimentos do turismo ecológico e cientifico e promover ações de educativas para a preservação da geodiversidade.

O Brasil adotou ainda o Programa Geoparques da UNESCO como forma de proteger e divulgar o seu patrimônio geológico. O Geoparque Araripe foi fundado em 21 de setembro de 2006, está localizado no estado do Ceará na região do Cariri. Sua extensão é de $3.796 \mathrm{~km}^{2}$ abrangendo os municípios de Crato, Juazeiro do Norte, Batalha, Missão Velha, Nova Olinda e Santana do Cariri. Embora o destaque do geoparque seja para o patrimônio geológico, representado por nove geossítios distribuídos no Araripe, outros aspectos de ocorrência na região também ganharam destaque, como a biodiversidade, a história e cultura, e arqueologia (ARARIPE, 2014).

Mais recentemente no Brasil, a temática da geoconservação vem se destacando por meio dos trabalhos e encontros científicos e pela criação de linhas de pesquisa nos Programas de Pós-Graduação. Como exemplos de trabalhos pioneiros estão a "Proposta Metodológica para o Inventário do Patrimônio Geológico Brasileiro" apresentado por Lima (2008) e o trabalho apresentado por Pereira (2010) "Geoconservação e Desenvolvimento Sustentável na Chapada Diamantina (Bahia Brasil)", ambos apresentam um panorama histórico sobre o tema, e sugerem metodologias aplicáveis para a geoconservação no Brasil.

A realização do II Congresso Latino-americano e do Caribe de Geoturismo e I Simpósio Brasileiro de Patrimônio Geológico realizado na Cidade do Rio de Janeiro, 2011 e o GeoBRheritage - II Simpósio Brasileiro de Patrimônio Geológico e I Workshop Brasileiro de Patrimônio Geológico Construído realizado na Cidade de Ouro Preto, Minas Gerais, 2013, foram marcados fortemente por evidenciar o avanço das discussões e novas iniciativas no território nacional. 
O programa de Pós-graduação em Geociências (Mineralogia e Petrologia) do Instituto de Geociências da Universidade de São Paulo - USP criou em 2012 a linha de pesquisa Patrimônio Geológico Natural e Construído e Geoconservação, que atualmente conta com seis projetos de mestrado e doutorado em andamento e dois projetos de iniciação cientifica, que estão ligados ao Núcleo de Apoio à Pesquisa em o Patrimônio Geológico e Geoturismo - GeoHereditas, fundado em 2011 por incentivo da Pró-Reitoria de Pesquisa da USP. Em 2014, foi inserida a linha de pesquisa Geoconservação e Patrimônio Geológico, no programa de Pós-graduação em Geologia da Universidade Federal do Paraná - UFPR. Na Universidade Federal do Rio Grande do Norte - UFRN trabalhos sobre a temática vem sendo desenvolvidos junto ao Programa de Pós-graduação em Turismo.

\subsection{Geoturismo: aspectos históricos, definições e planejamento}

A primeira definição de Geoturismo aparece em 1995, por Hose: o Geoturismo propõe facilitar o entendimento e fornecer facilidades de serviços para que turistas adquiram conhecimentos da geologia e geomorfologia de um lugar, indo além de meros espectadores de uma beleza estética.

Em 2000 Hose revisa a primeira definição, considerando o geoturismo como a disponibilização de serviços e meios interpretativos que promovem o valor e os benefícios sociais de lugares com atrativos geológicos e geomorfológicos, assegurando sua conservação, para o uso de estudantes, turistas e outras pessoas com interesses recreativos e de lazer (HOSE, 2000 p. 136 apud MOREIRA, 2011).

A mesma autora ainda apresenta as definições de Dowling \& Newsome ${ }^{5}$ (2006), o geoturismo é composto por dois elementos centrais: a geologia e geomorfologia. Para Frey ${ }^{6}$ et al. (2006), o geoturismo é um novo setor econômico caracterizado por transferir e comunicar o conhecimento geocientífico ao publico em

\footnotetext{
5 DOWLING, R. NEWSOME, D. Geotourism's issues and challenges. In: DOWLING, R e NEWSOME, D.(Edits.) Geotourism. Oxford: Elsevier Butterworth Heinemann. P.242-254. 2006.

${ }^{6}$ FREY, M. L; SCHAFER, K; BUCHEL, G; PATZAK, M. Geoparks - a regional European and global policy. In: DOWLING, R e NEWSOME, D.(Edits.) Geotourism. Oxford: Elsevier Butterworth Heinemann. P.95-118. 2006.
} 
geral, por meio da interação de diferentes áreas do conhecimento, como a geociências e o turismo.

A National Geographic Society (NGS) e a Travel Industry Association dos Estados Unidos (2001) definem o geoturismo como "uma vertente do turismo que mantém ou reforça as características do local a ser visitado, concretamente o seu ambiente cultural, estético, patrimônio, sem esquecer o bem-estar dos seus residentes" (BRILHA, 2005 p. 121).

Ruchkys (2007) entende o geoturismo como uma atividade turística que tem o patrimônio geológico como seu principal atrativo e busca sua proteção por meio da sensibilização do turista, utilizando a interpretação desse patrimônio de modo acessível para o público leigo e popularizando o conhecimento geocientífico.

Mais recentemente, em reconhecimento a necessidade de clarificar o conceito de geoturismo, em Novembro de 2011, de acordo com a Declaração de Arouca, Portugal, conceitua-se que: geoturismo deve ser definido como o turismo que sustenta e incrementa a identidade de um território, considerando a sua geologia, ambiente, cultura, valores estéticos, património e o bem-estar dos seus residentes. (AROUCA, 2011).

Partindo destes conceitos, percebe-se que o geoturismo constitui uma importe ferramenta no âmbito da geoconservação. Porém, assim como os demais seguimentos do turismo, deve ser detalhadamente planejado. Neste sentido, Moreira $(2008,2011)$ sugere que o geoturismo nas áreas protegidas deve ser planejado em diferentes etapas: inventário de pontos de interesse geológico, que deve ser feito por uma equipe multidisciplinar, levando em conta as bibliografias sobre a região; a definição dos objetivos e metas; o desenvolvimento de ações, como a interpretação ambiental, elaboração de roteiros didáticos e a realização de cursos voltados aos monitores ambientas das unidades de conservação; e o gerenciamento, avaliação e monitoramento a fim de verificar a eficiência das ações desenvolvidas.

No que diz respeito à intepretação ambiental, esta já é uma prática bastante desenvolvida nas Unidades de Conservação (UC) em temas relacionados, principalmente, a conservação da biodiversidade. No contexto do geoturismo, esta 
prática se constituiria pela informação sobre o patrimônio geológico e a geoconservação aliada conservação da biodiversidade.

A intepretação em determinado local deve ser pensada para estimular a curiosidade do turista e fornecer bases para que posteriormente possa buscar informações sobre determinado tema. Para tanto, existem uma gama de meios interpretativos que podem ser utilizados, como a utilização de placas de sinalização, os painéis interpretativos, trilhas guiadas e autoguiadas, dentre outros. Neste sentido a seguir serão apresentadas algumas iniciativas brasileiras no que diz respeito à divulgação do patrimônio geológico.

\subsubsection{Iniciativas de Geoturismo no Brasil}

O Brasil é internacionalmente reconhecido pela biodiversidade e geodiversidade que constituem belíssimas paisagens, além da grande riqueza histórico-cultural, que atrai turistas de todo mundo. Assim, existem diferentes seguimentos de turismo que são desenvolvidos no território nacional, que atendem os diferentes interesses dos viajantes como o turismo religioso, o turismo de aventura, o turismo histórico e cultural e o ecoturismo.

Decorrente da geodiversidade aqui encontrada, cada vez mais, se assiste ao emergir uma vertente do turismo em áreas naturais, que não só objetiva desfrutar de uma paisagem, mas sim compreender os processos geológicos que atuam na região (ALENCOÃO et al. 2010). Surgindo assim, o geoturismo - que propõe agregar o conhecimento científico ao patrimônio natural de forma agradável e compreensível, valorizando e possibilitando que aconteça uma visitação turística de modo sustentável (MINEROPAR, 2011). Além disso, contribui para o desenvolvimento econômico e valorização das comunidades locais. Como exemplos temos o projeto "Caminhos Geológicos" do Rio de Janeiro e o projeto "Monumentos Geológicos do Rio Grande do Norte".

O Projeto "Caminhos Geológicos" do Rio de Janeiro foi lançado no ano 2000, pelo Departamento de Recursos Minerais do Rio de Janeiro (DRM-RJ) com o objetivo de divulgar o conhecimento geocientífico e chamar atenção para preservação dos monumentos geológicos para o público em geral, por meio da 
instalação de painéis interpretativos. O projeto conta com o apoio cientifico das universidades, prefeituras e ONGs (LIMA, 2008). O projeto já implantou tem 103 painéis e 28 municípios do Estado (DRM-RJ, 2014).

O "Projeto Monumentos Geológicos do Rio Grande do Norte", foi lançado em 2006, pelo Instituto de Desenvolvimento e Meio Ambiente do Rio Grande do Norte (IDEMA) e PETROBRÁS em parceria com o Serviço Geológico do Brasil (CPRM) e apoio da Universidade Federal do Rio Grande do Norte (UFRN) e o Centro Federal de Educação Tecnológica do Rio Grande do Norte (CEFET_RN). Com o intuito de reconhecer, preservar e divulgar os monumentos geológicos do estado do Rio Grande do Norte, ao longo das rotas turísticas, foram instalados 16 painéis interpretativos com informações sobre os conteúdos geológicos com uma linguagem bem simples, para ser compreendida pelo público leigo. Os painéis contribuíram também para o desenvolvimento socioeconômico (NASCIMENTO ${ }^{7}$ et al., 2008 apud LIMA, 2008).

7 NASCIMENTO, M. A. L. do; RUCHKYS, U. A. \& MANTESSO-NETO, V. Geodiversidade, Geoconservação e Geoturismo-Trinômio importante para a proteção do patrimônio geológico. SBG. Brasil. 84 p. 2008. 


\section{AS UNIDADES DE CONSERVAÇÃO NO BRASIL}

O conceito de Área Protegida ou Unidades de Conservação (UC) surgiu no Brasil com a criação do Parque Nacional de Itatiaia em 1937, situado na Serra da Mantiqueira na divisa dos estados do Rio de Janeiro e Minas Gerais. Em 1939, foram criados o Parque Serra dos Órgãos no Rio de Janeiro, o Parque do Iguaçu e Sete Quedas no Paraná, refletindo o início da sensibilização mundial para a necessidade de existência de áreas naturais intencionalmente protegidas, iniciado nos Estados Unidos com a criação do Yellowstone Nacional Park em 1872. Desde então, com o objetivo de proteger e manter as áreas naturais existentes, o poder público vem adotando medidas legais para garantir a integridade destes espaços, além de ordenar às atividades econômicas e disciplinar a implantação de projetos e obras que possam causar impactos significativos nestas áreas.

As décadas de 40 e 50 passaram sem a criação de novas Unidades de Conservação. Na década de 60 foi criado o Instituto Brasileiro do Desenvolvimento Florestal - IBDF (Decreto - Lei no 289 de 1967), que, desde então, passou a ser responsável pela administração das Unidades já criadas e criar novos parques nacionais.

Na década de 70, logo após a Primeira Conferência das Nações Unidas para o Meio Ambiente, realizada em Estocolmo, Suécia, em 1972, no Brasil foi criada a primeira reserva biológica do país, no estado do Rio de Janeiro, a Rebio Poço das Antas, (Decreto - Lei $n^{\circ} 73.791$ de 11.03.1974) importante porque constitui dos últimos remanescentes habitat do mico-leão-dourado, espécie ameaçada de extinção.

Na década de 80 foram criadas 33 Unidades de Conservação, representando um marco histórico na criação de novas Unidades. Com a Instituição da Secretaria Especial do Meio Ambiente (SEMA) do Ministério Interior, uma nova categoria de Unidades de Conservação foi criada, a Estação Ecológica (Lei № 6.902 de 27 de abril de 1981). Pouco tempo depois, foi instituída a criação da Área de Proteção Ambiental (APA) como uma nova forma de conceituar defesa da biodiversidade, podendo ser implantadas em áreas públicas ou privadas. No final dos anos 80 , duas novas categorias foram criadas: as reservas ecológicas e as áreas de interesse 
ecológico. Estas foram reconhecidas como UC pela Resolução $n^{\circ} 12$, de 14 de Dezembro de 1987, do CONAMA (Conselho Nacional do Meio Ambiente) (DRUMMOND et al., 2010).

A década de 90 foi marcada fortemente por discussões a respeito da dificuldade de sistematizar a criação e gestão a das diversas categorias de UCs no Brasil. Ao final de um longo trâmite no Congresso Nacional foi criada a Lei № 9.985 de 18 de julho de 2000 que estabeleceu o Sistema Nacional de Unidades de Conservação da Natureza (SNUC), definido como (MMA, 2014)

O conjunto de unidades de conservação (UC) federais, estaduais e municipais. É composto por 12 categorias de UC, cujos objetivos específicos se diferenciam quanto à forma de proteção e usos permitidos: aquelas que precisam de maiores cuidados, pela sua fragilidade e particularidades, e aquelas que podem ser utilizadas de forma sustentável e conservadas ao mesmo tempo.

De acordo com o SNUC, Unidades de Conservação são definidas como

Espaços territoriais, incluindo seus recursos ambientais, com características naturais relevantes, que têm a função de assegurar a representatividade de amostras significativas e ecologicamente viáveis das diferentes populações, habitats e ecossistemas do território nacional e das águas jurisdicionais, preservando $\mathrm{o}$ patrimônio biológico existente.

Estão divididas em dois grupos: Unidades de Proteção Integral e Unidades de Uso Sustentável (MMA, 2014).

As Unidades de Proteção Integral têm o objetivo de preservar a natureza admitindo apenas o uso indireto dos seus recursos naturais. As categorias de proteção integral são: Estação Ecológica (EE), Reserva Biológica (REBIO), Parque Nacional (PARNA), Monumento Natural (MN) e Refúgio de Vida Silvestre (RVS).

As Unidades de Uso Sustentável objetivam compatibilizar a conservação da natureza com o uso sustentável de parcela de seus recursos naturais. As categorias de uso sustentável são: Área de Relevante Interesse Ecológico (ARIE), Floresta Nacional (Flona), Reserva de Fauna (RF), Reserva de Desenvolvimento Sustentável 
(RDS), reserva extrativista, Área de Proteção Ambiental (APA) e Reserva Particular do Patrimônio Natural (RPPN).

As categorias de Tombamento e Área Especial de Interesse Turístico não são contempladas pela lei 9985/00, sendo regidas, respectivamente pelo Decreto-lei 25/37 e pela lei 6513/77.

Deste modo, segundo o SNUC, Lei № 9.985, de 18 de Julho de 2000, que agrupa as Unidades de Conservação em Unidades de Proteção Integral e Unidades de Uso Sustentável, as categorias de manejo ocorrentes na área de estudo são Parque Nacional (PARNA) e Área de Proteção Ambiental (APA), definidas abaixo:

A Lei 9985/00 (Art. 11.) define:

O Parque Nacional tem como objetivo básico a preservação de ecossistemas naturais de grande relevância ecológica e beleza cênica, possibilitando a realização de pesquisas científicas e o desenvolvimento de atividades de educação e interpretação ambiental, de recreação em contato com a natureza e de turismo ecológico.

$\S 1^{\circ}$ O Parque Nacional é de posse e domínio públicos, sendo que as áreas particulares incluídas em seus limites serão desapropriadas, de acordo com o que dispõe a lei.

$\S 2^{\circ} \mathrm{A}$ visitação pública está sujeita às normas e restrições estabelecidas no Plano de Manejo da unidade, às normas estabelecidas pelo órgão responsável por sua administração, e àquelas previstas em regulamento.

§ 3ํㅗ A pesquisa científica depende de autorização prévia do órgão responsável pela administração da unidade e está sujeita às condições e restrições por este estabelecidas, bem como àquelas previstas em regulamento.

$\S 4^{\circ}$ As unidades dessa categoria, quando criadas pelo Estado ou Município, serão denominadas, respectivamente, Parque Estadual e Parque Natural Municipal. 
As Áreas de Proteção Ambiental, segundo o Ministério do Meio Ambiente (MMA, 2014) são definidas como

\begin{abstract}
Área dotada de atributos naturais, estéticos e culturais importantes para a qualidade de vida e o bem-estar das populações humanas. Geralmente, é uma área extensa, com o objetivo de proteger a diversidade biológica, ordenar o processo de ocupação humana e assegurar a sustentabilidade do uso dos recursos naturais. É constituída por terras públicas e privada.
\end{abstract}

\title{
3.1. As Unidades de Conservação do estado de São Paulo
}

O Instituto Florestal (IF), criado em 1986, é uma entidade vinculada à Secretaria do Meio Ambiente e responsável pelo gerenciamento e proteção e conservação das reservas do estado de São Paulo, tarefa que começou a dividir com a Fundação Florestal a partir de 2007. Atualmente o IF administra 10 Estações Ecológicas, 1 Parque Estadual, 18 Estações Experimentais, 2 Viveiros Florestais, 2 Hortos Florestais e 14 Florestas Estaduais (mais de 53 mil ha), além de apoiar a gestão da Reserva da Biosfera do Cinturão Verde da Cidade de São Paulo (Programa MaB-UNESCO) (IF,2014).

A Fundação para a Conservação e a Produção Florestal do Estado de São Paulo, foi instituída pela Lei Estadual $n^{\circ} 5.208$, de $1^{\circ}$ de julho de 1.986 , sendo seu estatuto aprovado pelo Decreto Estadual $n^{\circ} 25.952$, de 29 de setembro de 1.986. Atualmente é responsável pela comercialização de produtos extraídos das florestas em áreas plantadas que pertencem ao Estado e pelo manejo de 94 Unidades de Conservação incluindo o Parque Estadual da Serra do Mar e o Parque Estadual da Ilha Anchieta no Município de Ubatuba e a APA Marinha do Litoral Norte. 


\subsubsection{O Parque Estadual da Ilha Anchieta}

A Ilha Anchieta localiza-se no litoral norte do estado de São Paulo, entre as coordenadas geográficas $23^{\circ} 31^{\prime}$ e $23^{\circ} 34^{\prime}$ de latitude Sul e $45^{\circ} 02^{\prime}$ e $45^{\circ} 05^{\prime}$ de longitude Oeste de Greenwich, entre os municípios de Ubatuba, Caraguatatuba, São Sebastião e Ilhabela (ROBIM et al. 2008). É a segunda maior ilha do estado, com 828 hectares encobertos pela Mata Atlântica e onde se encontram belíssimas paisagens, praias, costões rochoso e uma grande biodiversidade.

Por volta de 1550 , os primeiros habitantes da llha Anchieta que se tem conhecimento, foram os índios Tamoios e Tupinambás, liderados pelo Cacique Cunhambebe, considerado um personagem de extrema importância, pois nessa época ocorriam diversos conflitos entre os índios e portugueses. E em torno dele se articulou todo o trabalho com o Padre José de Anchieta a fim de conseguir a paz entre os índios e portugueses (OLIVEIRA, 2009).

A aproximação de Cunhambebe dos Jesuítas Padre José de Anchieta e Manoel da Nóbrega resultou no Tratado de Paz de Iperoig, assinado em 14 de Setembro de 1563. Foi iniciada então a ocupação da ilha, não só por portugueses, mas também por holandeses, franceses e outros europeus, que viviam basicamente da pesca e agricultura.

Durante o século XVII, a ilha abrigou o destacamento do exército português. Em 1850 foi criada uma Base da Marinha Inglesa para o combate do tráfico de escravos negros africanos, já proibidos por lei. Em 1885, a ilha passou a ser denominada Freguesia do Senhor Bom Jesus da Ilha dos Porcos.

No século XVIII, em 1902, a Ilha era mais conhecida como Ilha dos Porcos, quando nela foi construída uma Colônia Correcional e um Instituto Disciplinar. Em 1934 a Ilha dos Porcos passou a ser denominada Ilha Anchieta, em comemoração ao quarto centenário do nascimento do Padre José de Anchieta. O Presídio da Ilha, que abrigava cerca de 950 pessoas, ficou conhecido como Presídio Político da llha Anchieta (OLIVEIRA, 2009).

Em 1952, liderada por João Pereira Lima, ocorreu na ilha a maior rebelião que se tem registro. Após a rebelião foram recapturados 129 presos. Os presos foram julgados na própria ilha. 
Em 1955, a Colônia Penal da llha Anchieta foi fechada. Os presos foram transferidos para Casa de Custódia e Tratamento de Taubaté e para o Instituto de Reeducação de Tremembé. Em setembro do mesmo ano o soldado Xavier fica na ilha para preservar o patrimônio público (OLIVEIRA, 2009).

Em 29 de Março de 1977 a llha foi transformada em Parque Estadual, pelo Decreto de Lei 9.629:

Artigo $1 .^{\circ}$ - Fica criado o Parque Estadual da llha Anchieta com a finalidade de assegurar a integral proteção aos recursos naturais, bem como para a instalação de laboratório com objetivos científicos, especialmente os destinados ao incentivo da maricultura.

Artigo $2^{\circ}$ - A administração do Parque Estadual da llha Anchieta fica atribuída à Secretaria da Agricultura.

Artigo $3^{\circ}$ - Este decreto entrará em vigor na data de sua publicação, revogado o Decreto $n^{\circ} 4.406$, de 3 de setembro de 1974, que transferiu a administração da llha Anchieta ao Fomento de Urbanização e Melhorias das Estâncias - FUMEST.

O PEIA constitui um dos principais destinos turísticos de Ubatuba. Dentre os principais atrativos estão as ruínas do antigo presídio, o antigo quartel e as trilhas ecoturísticas: Trilha do Engenho, Trilha do Saco Grande, Trilha da Praia do Sul, Trilha da Represa e Trilhas Subaquáticas.

Atualmente os turistas que visitam a ilha podem permanecer duas horas no local, em geral, tempo durante o qual é realizado o percurso das trilhas ecoturísticas com o acompanhamento dos monitores ambientais do parque. Durante o mês de janeiro é possível realizar o percurso das trilhas subaquáticas, realizadas em parceria com o Instituto de Biociências da Universidade de São Paulo por meio da ONG Ecosteiros. Ao todo são cinco trilhas, com pontos de interpretação ambiental em que os visitantes podem aprender e discutir questões de Educação Ambiental, bem como a preservação do ambiente local. 


\subsubsection{O Parque Estadual da Serra do Mar - Núcleo Picinguaba}

O Parque Estadual da Serra do Mar foi criado em 30 de agosto de 1977, pelo Decreto $N^{\circ} 10.251$ (30/08/1977). Sua área corresponde a 315.390 hectares abrangem parte de 23 municípios, desde Ubatuba, na divisa com o estado do Rio de Janeiro, até Pedro de Toledo no litoral sul, incluindo Caraguatatuba, São Sebastião, Bertioga, Cubatão, Santos, São Vicente, Praia Grande, Mongaguá, Itanhaém e Peruíbe. Na região do planalto abrigam cabeceiras formadoras dos rios Paraíba do Sul, Tietê e Ribeira de Iguape, nos municípios de Cunha, São Luiz do Paraitinga, Natividade da Serra, Paraibuna, Salesópolis, Biritiba Mirim, Mogi das Cruzes, Santo André, São Bernardo do Campo, São Paulo e Juquitiba.

De acordo com o decreto:

O Parque Estadual da Serra do Mar foi criado com a finalidade de assegurar integral proteção à flora, à fauna, às belezas naturais, bem como para garantir sua utilização a objetivos educacionais, recreativos e científicos e caracteriza-se por ser uma Unidade de Conservação de Proteção Integral.

O Parque é gerenciado por meio de oito núcleos administrativos, em função da sua grande área de extensão, pois facilita sua gestão. Três sedes estão no planalto: Cunha, Santa Virginia e Curucutu e cinco na região litorânea: Picinguaba, Caraguatatuba, São Sebastião, Cubatão e Pedro de Toledo. Os núcleos foram formados e caracterizados em função do uso do solo e dos programas de manejo desenvolvidos ou potenciais, considerando ainda o domínio das terras, que são públicas ou estão em diversos estágios de regularização fundiária. (MATOSSO, 2006).

O Núcleo Picinguaba está localizado no município de Ubatuba, litoral norte do estado de São Paulo. Limita-se com o PARNA Serra da Bocaina e com a APA Cairuçu no estado do Rio de Janeiro. Juntamente com outras 14 Ucs de São Paulo e Rio de Janeiro, forma o corredor de proteção da Mata Atlântica.

O único ponto do Parque Estadual da Serra do Mar que atinge a orla marítima, a floresta em Picinguaba chega até os costões rochosos e se espalha pela planície litorânea em sete praias. Sua área de abrangência é de 47.000 ha, 
totalmente inserido em Ubatuba. Do núcleo fazem parte a Vila Picinguaba, uma aldeia de pescadores na Praia do Cambury e um agrupamento de pequenos posseiros no sertão da Fazenda Picinguaba, que caracterizam o local como um reduto de comunidades tradicionais caiçaras e quilombolas.

O Núcleo Picinguaba oferece diversas trilhas, porém a maior parte delas apresenta grau de dificuldade elevado. São preferidas pelos visitantes aquelas que desembocam em praias, sendo por isso trilhadas parcialmente. São as trilhas mais procuradas: trilha do Picadão da Barra ou Mangue (nível fácil), trilha da Casa de Farinha e Jatobá (nível fácil), trilha da Praia Brava até Almada (nível médio), trilha do Corisco (nível difícil) e trilha Cambury-Trindade (nível médio a difícil). Há muitas outras trilhas de nível médio a difícil, porém os roteiros devem ser solicitados aos monitores ambientais (PROCHOROFF \& SANTOS, $2010^{8}$ ).

O núcleo possui um centro de visitantes com uma sala de exposições, onde se podem ver os diferentes ecossistemas encontrados no parque (praia, costão rochoso, manguezal, restinga e mata de encosta) em maquetes trabalhadas, nas quais existem materiais coletados (rochas, sedimentos, carcaças de animais marinhos) que os visitantes podem manipular, sentindo-se assim mais próximos do objeto de estudo e aumentando sua capacidade de compreensão. Além disso, o núcleo oferece atividades de Educação Ambiental e ecoturismo que promovem a preservação ambiental e patrimonial no que diz respeito às comunidades tradicionais (PROCHOROFF \& SANTOS, 2010¹).

\subsubsection{A APA Marinha do Litoral Norte do Estado de São Paulo}

Em 2008 o governo do estado de São Paulo criou três APAs Marinhas, do Litoral Sul, do Litoral Centro e do Litoral Norte que se estendem ao longo do litoral de São Paulo. Por meio do Decreto de Lei ${ }^{\circ} 53.525$ de 08 de Outubro de 2008 estas UC foram criadas com o objetivo de proteger e ordenar o uso dos recursos

\footnotetext{
${ }^{8}$ PROCHOROFF, R.C. \& SANTOS, P.L.A. Avaliação da potencialidade dos afloramentos nas trilhas na Mata Atlântica entre Caraguatatuba e Ubatuba, litoral norte do Estado de São Paulo: aspectos de preservação e divulgação. Relatório de Iniciação Científica, aceito pela Pró-Reitoria de Graduação da Universidade de São Paulo, 2010.
} 
ambientais na região, além de complementar a proteção ao entorno dos Parques Estaduais da Serra do Mar, da IIha Anchieta, de Ilhabela, da Laje de Santos, da Ilha do Cardoso e federais, como as Estações Ecológicas Tupinambás e Tupiniquins.

A APA Marinha do Litoral Norte é composta por três setores: Cunhambebe, situado nos municípios de Caraguatatuba e Ubatuba, o setor Maembipe situado no município de Ilhabela e o setor Ypautiba no município de São Sebastião.

No Município de Ubatuba, ainda são inclusos os manguezais localizados na Praia da Lagoa e os Rios Indaiá, Tavares, Maranduba, Ubatumirim, Cumprido e Escuro, Onça, Puruba, Prumirim, Itamambuca e a llha do Mar Virado, sendo controlada a atividade pesqueira.

A administração da APA Marinha é feita por meio de um Conselho Gestor, que deve ser trocado a cada dois anos, formado por 24 membros titulares e 24 membros suplentes. Metade dos representantes é indicada pelos governos federal, estadual e municipal e a outra metade por membros da sociedade civil que representam os setores de pescadores, armadores de pesca, monocultores e pesquisadores (FF, 2014).

\subsection{Plano de Manejo e Uso Público}

O Plano de manejo é um documento que explicita os objetivos da UC, indicando que tipos de atividades poderão ser realizados. É um documento baseado em estudos da biodiversidade, geodiversidade e aspectos sociais, que estabelece as normas e restrições quanto ao uso dos recursos naturais e para a implantação de estruturas físicas na área total da UC e ao seu entorno, quando necessário formando corredores ecológicos. Em geral, a ferramenta mais usada no plano de manejo é o zoneamento da UC, que estabelece o grau de proteção e regras de uso. Inclui também medidas para promover o desenvolvimento socioeconômico e socioambiental por meio da participação das comunidades vizinhas e pesquisas científicas, mostrados na tabela a seguir (Tabela 3.2.1). 
Assim, na área de abrangência deste trabalho as UC se enquadram nas classes 2 e 6, que comtemplam o turismo em contato com a natureza em terras públicas e particulares com possibilidades de usos variados visando um ordenamento territorial sustentável. Tanto o PEIA quanto o PESM podem ser caracterizados como locais com grade potencial turístico em que o visitante tem acesso e contato com a natureza por meio das trilhas ecoturísticas e dos trabalhos de educação ambiental, nos quais as questões relacionadas à biodiversidade são tratadas de maneira excepcional. Entretanto a geodiversidade local ainda não tem sido alvo dos trabalhos dessas práticas desenvolvidas nas UC. Nesse sentido o geoturismo aliado ao conhecimento da biodiversidade se mostra uma ferramenta valiosa para a compreensão e preservação do meio como um todo.

\begin{tabular}{|c|c|c|}
\hline Chasse & $\begin{array}{c}\text { Principais tipos de uso, contemplados } \\
\text { na Leino 9.985/2000 }\end{array}$ & Categoria de manejo \\
\hline $\begin{array}{l}\text { Classe } 1 \text { - Pesquisa científica e } \\
\text { educą̧äo ambiental }\end{array}$ & $\begin{array}{c}\text { Deservolvimento de pesquisa científica } \\
\text { e de educaçäo ambiental }\end{array}$ & Reserva biológica; estação ecológica \\
\hline $\begin{array}{l}\text { Classe } 2 \text { - Pesquisa cie ntífica, educaçäo } \\
\text { ambiental e visitação }\end{array}$ & Turismo em contato com a natureza & $\begin{array}{l}\text { Parques nacionais e estaduais, reserva } \\
\text { particular do patrimônio natural }\end{array}$ \\
\hline $\begin{array}{l}\text { Classe } 3 \text { - Produçäo florestal, pesquisa } \\
\text { cientifica e visitaçäo }\end{array}$ & Produção florestal & Florestas racionais e estaduais \\
\hline $\begin{array}{l}\text { Classe 4-Extrativismo, pesquisa } \\
\text { cientifica e visitaçäo }\end{array}$ & $\begin{array}{l}\text { Extrativismo por populaçöes } \\
\text { tradicionais }\end{array}$ & Reseervas extrativistas \\
\hline $\begin{array}{l}\text { Classe S - Agricultura de baixo } \\
\text { impacto, pesquisa científica, visitaçäo, } \\
\text { produçäo florestal e extrativismo }\end{array}$ & $\begin{array}{c}\text { Áreas públicas e privadas onde a } \\
\text { produçäo agrícola e pec uána é } \\
\text { compa tbilizada com os obje tivos da } \\
\text { UC }\end{array}$ & $\begin{array}{l}\text { Reserva de deservolvimento } \\
\text { sustentivel; refúgio de vida silvestre; } \\
\text { monumento natural }\end{array}$ \\
\hline $\begin{array}{l}\text { Classe } 6 \text { - Agropecuánia, atividade } \\
\text { industrial, nucleo populacional urbano e } \\
\text { rural }\end{array}$ & $\begin{array}{l}\text { Terras públic as e particulares com } \\
\text { possibilidade de usos variados visando a } \\
\text { um ordenamento temitorial sustentável }\end{array}$ & $\begin{array}{l}\text { Área de proteção ambiental; área de } \\
\text { re levante interesse ecológico }\end{array}$ \\
\hline
\end{tabular}

Tabela 3.2.1. Principais tipos de uso permitidos nas Unidades de Conservação. Fonte: DAP/SBF/MMA, 2009. 


\subsection{Interpretação Ambiental no contexto das Unidades de Conservação: definição e meios interpretativos}

As Unidades de Conservação no Brasil, de acordo com o SNUC, constituemse de territórios com características naturais relevantes incluindo os recursos naturais que têm a função de assegurar a representatividade dos diferentes habitats e ecossistemas do território nacional, assegurando a proteção do patrimônio biológico.

Visando a conservação deste patrimônio foram criadas diferentes categorias de manejo, as quais definem o tipo de atividade que se pode realizar nestes espaços. Como explicitado, anteriormente, as categorias de manejo que compreendem a região enfocada neste trabalho, Parque Nacional (PARNA) e Área de Proteção Ambiental (APA) preveem a visitação pública, a realização de pesquisas científicas, atividades de educação ambiental e o uso e territorial visando o desenvolvimento sustentável.

Neste sentido, as UC constituem-se de excelentes espaços para o desenvolvimento de atividades recreativas, educativas e interpretativas. Estas atividades, quando são bem planejadas, podem representar uma das formas mais eficazes na promoção da sensibilização ambiental e ações em prol do ambiente por parte dos visitantes (MOREIRA, 2011; BENTO, 2013).

Segundo Moreira (2011 p.72) "o conceito de educação ambiental tem sua origem vinculada à ideia de natureza e como protegê-la". Este conceito é definido pela Lei n 9.795 de abril de 1999:

Art. $1^{\circ}$ Entendem-se por educação ambiental os processos por meio dos quais o indivíduo e a coletividade constroem valores sociais, conhecimentos, habilidades, atitudes e competências voltadas para a conservação do meio ambiente, bem de uso comum do povo, essencial à sadia qualidade de vida e sua sustentabilidade.

Dentre os principais objetivos da educação ambiental estão: (i) o desenvolvimento de uma compreensão integrada do meio ambiente em suas múltiplas e complexas relações, envolvendo aspectos ecológicos, psicológicos, 
legais, políticos, sociais, econômicos, científicos, culturais e éticos; (ii) o estímulo e o fortalecimento de uma consciência crítica sobre a problemática ambiental e social; (iii) o incentivo à participação individual e coletiva, permanente e responsável, na preservação do equilíbrio do meio ambiente, entendendo-se a defesa (Lei $\mathrm{n}^{\circ}$ 9.795, 1999).

Deste modo, a interpretação ambiental é a forma de comunicação realizada para entender o meio ambiente e suas relações, em especial em áreas de proteção ambiental, portanto, pode ser considerada como parte da educação ambiental (MOREIRA, 2011).

Tilden (1977 p.88) apud Prochoroff (2014) define a interpretação como "uma atividade educativa cujo objetivo é revelar os significados e as relações através do uso de objetos originais, pela experiência de primeira mão e por meios ilustrativos, ao invés de simplesmente comunicar informação factual".

Para Moreira (2011) a interpretação ambiental facilita o conhecimento cientifico e a apreciação da natureza, ao passo que traduz esse conhecimento para uma linguagem acessível, comum a todas as pessoas. Portanto, a interpretação ambiental pode ser considerada um forte aliado à conservação do patrimônio geológico.

Para tanto, podem ser utilizados diferentes meios interpretativos, tais como a sinalização e placas indicativas, painéis interpretativos, folhetos e trilhas autoguiadas que compõem os meios não personalizados. Também podem ser oferecidos 0 percurso de roteiros geoturísticos e trilhas guiadas, cursos de formação, dentre outros que compõem os meios personalizados.

A sinalização e placas indicativas é a comunicação efetuada por meio de um conjunto de placas de sinalização, implantadas sucessivamente ao longo de um trajeto estabelecido, com mensagens escritas e ordenadas, pictogramas e setas direcionais. "Esse conjunto é utilizado para informar os usuários sobre a existência de atrativos turísticos e de outros referenciais, sobre melhores percursos de acesso e, ao longo destes a distancia a ser percorrida para se chegar ao local pretendido". (MT, 2014). Para a colocação de placas de sinalização o Ministério do Turismo dispõem o "Guia Brasileiro de Sinalização Turística", o qual apresenta uma série de

\footnotetext{
${ }^{9}$ TILDEN, E. Interpreting our heritage. Chapel Hill, NC: University of North Carolina. 3rd ed. 1977. 41
} 
recomendações e exemplos de placas, que variam de acordo com o seguimento do turismo (Figura 3.3.1).

Em 2009 a Prefeitura de Ubatuba firmou um acordo com o Departamento de Apoio ao Desenvolvimento Turístico das Estâncias Turísticas (DADE) para a confecção e instalação das placas de sinalização turística do município. No território foram instaladas 400 placas, as quais orientam moradores de turistas quanto aos principais atrativos e rotas de interesse público. Ao lado das informações que se quer passar, em todas as placas adicionalmente foram colocadas imagens elaboradas pelo ilustrador Paulo Rogério de Mattos, que fazem alusão ao município: golfinho, peixe, navio, prancha de surfe, pássaro e barco de pesca (UBATUBA, 2014).

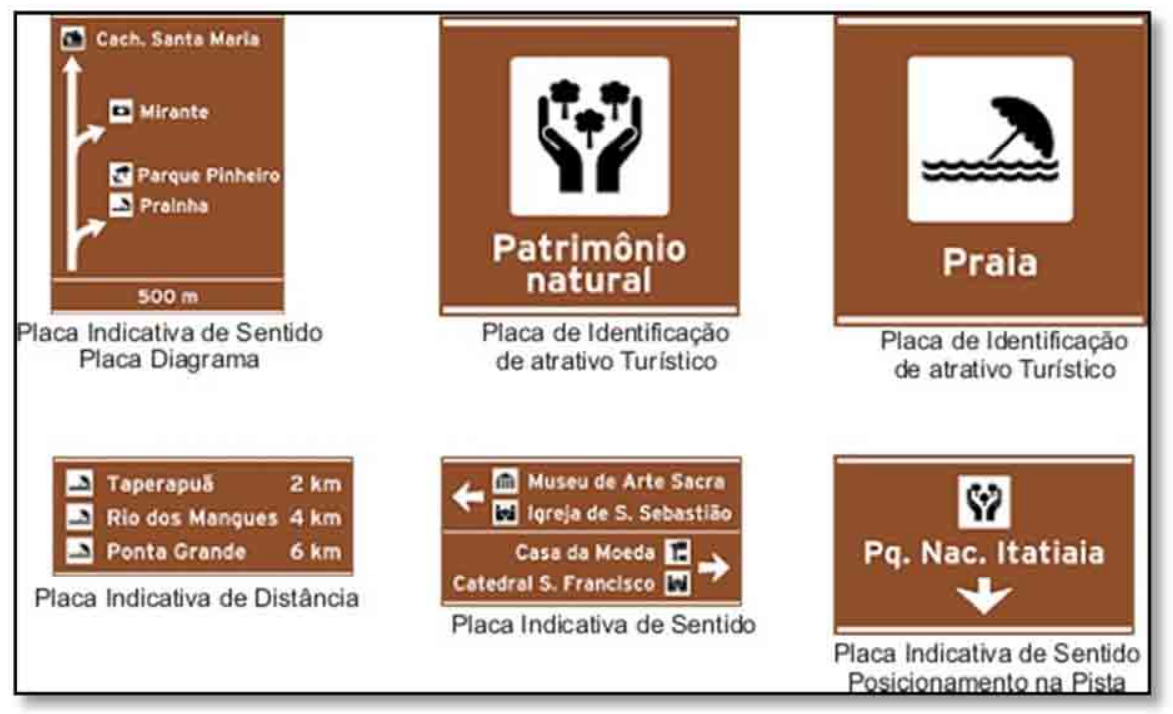

Figura 3.3.1 - Exemplos de placas de sinalização de atrativos turísticos. Fonte: Guia Brasileiro de Sinalização Turística (MT, 2014).

Os painéis interpretativos são ferramentas de comunicação muito usadas nas UC principalmente na divulgação da biodiversidade. Entretanto, diversos autores (HOSE, 2000; MOREIRA, 2011; VASCONCELOS, 2003; BRILHA, 2005) atentam quanto ao uso deste meio de comunicação. Em primeiro lugar, há de se ter bem claro o público alvo para que a linguagem e conteúdo sejam elaborados de maneira adequada. Posteriormente, como apontam os mesmos autores, as cores dos painéis não devem ser muito fortes, as letras de tamanho adequadas e quantidade de textos apresentados devem ser reduzidas e intercaladas com diferentes imagens. $O$ 
mesmo se aplica para a elaboração dos folhetos, que são formas muito comuns de divulgação, no entanto nem sempre são elaboradas de maneira adequada. Como exemplos do uso de painéis interpretativos na divulgação da geodiversidade temos o "Projeto Caminhos Geológicos", como abordado anteriormente (em 2.5.1) e o "Projeto Monumentos Geológicos do estado de São Paulo", que sinalizam locais de caráter científico e cultural, de conteúdos geológicos que ilustram importantes processos da história do Planeta Terra. (IG, 2014). Ambos abordam de maneira clara e sucinta diferentes conteúdos geológicos ilustrados pelos elementos da geodiversidade (Figura 3.3.2a/b).

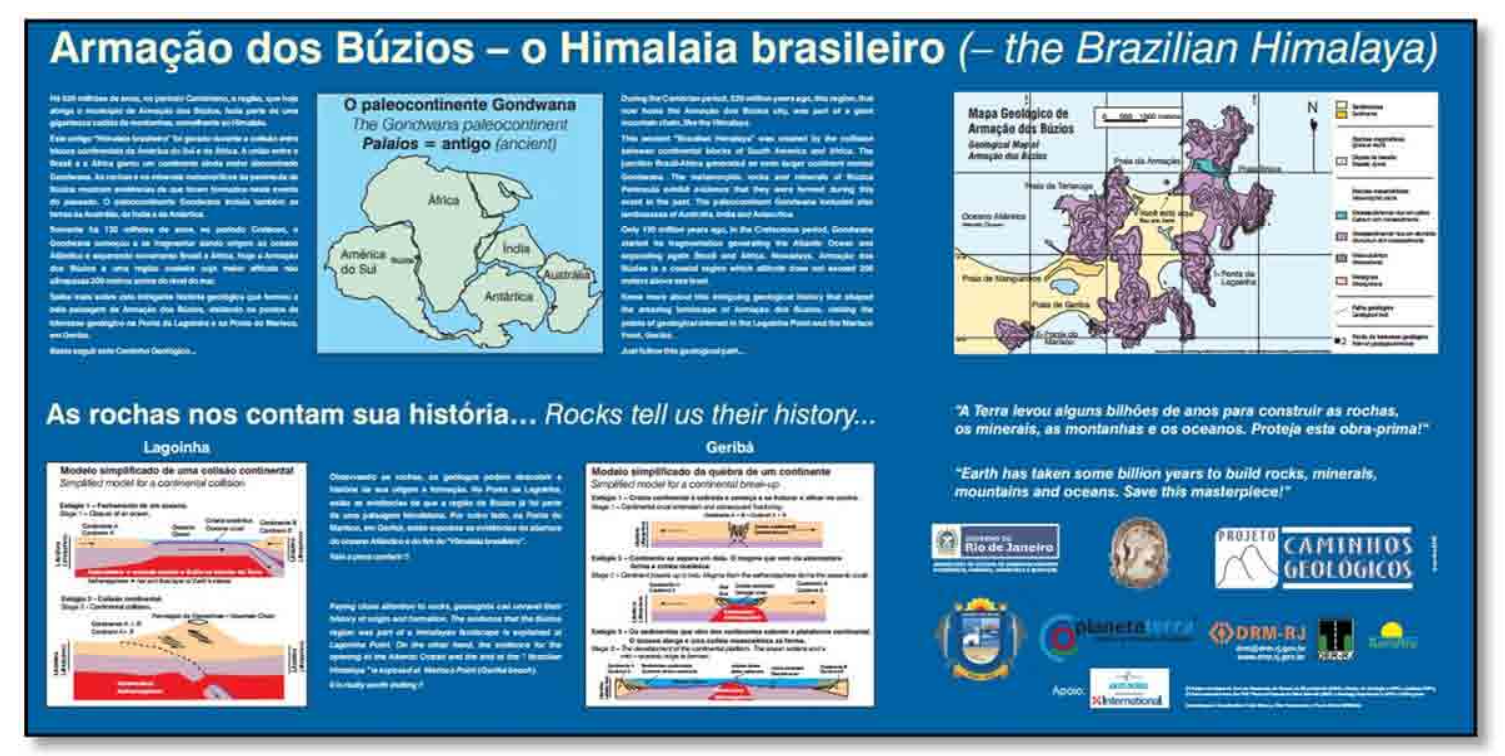

Figura 3.3.2a - Painel interpretativo "O Himalaia brasileiro", implantado pelo Projeto Caminhos Geológicos, RJ em 2001. Fonte: http://www.drm.ri.gov.br/. 


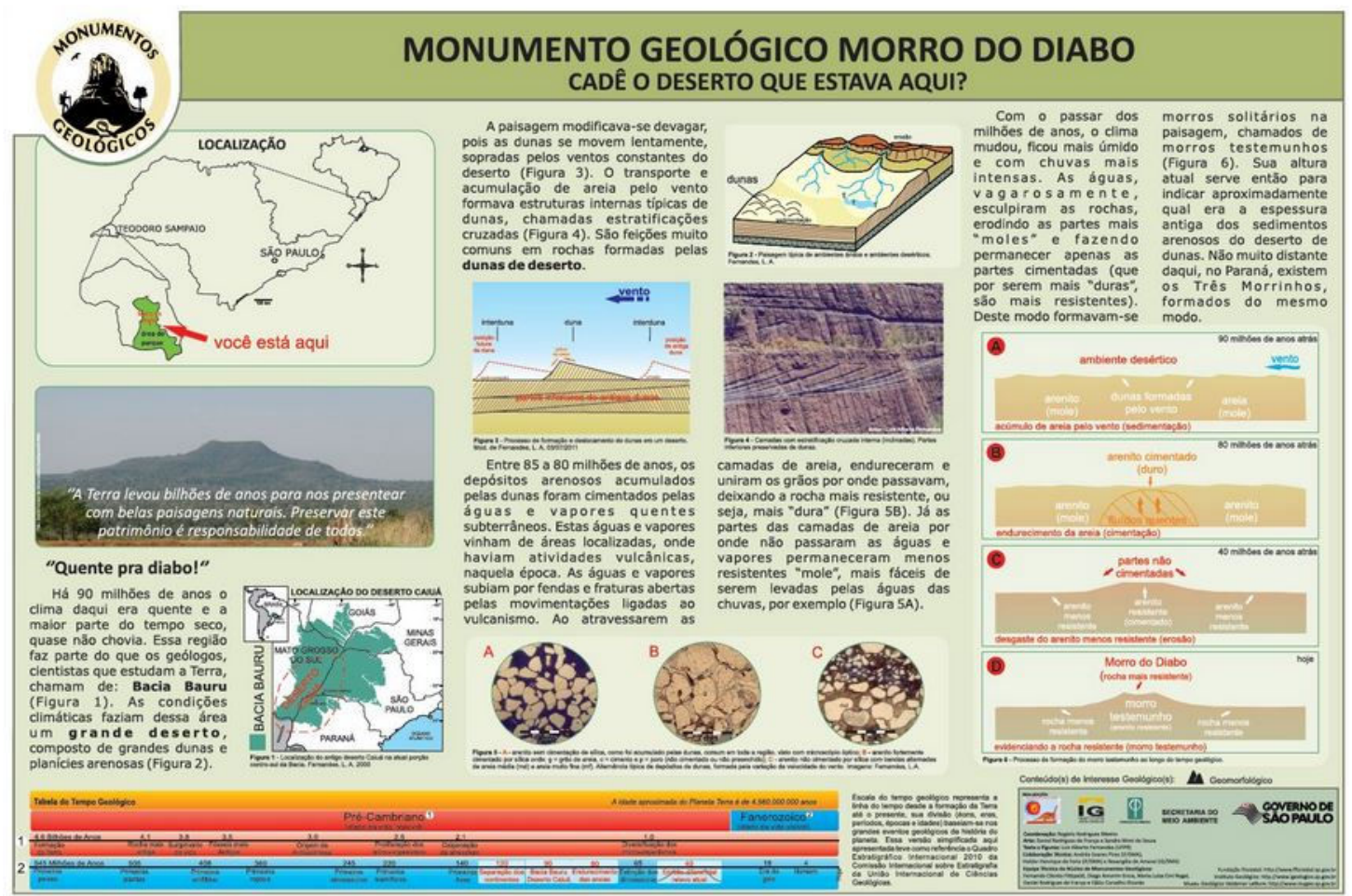

Figura 3.3.2b - Painel interpretativo do Monumento Geológico Morro do Diabo, SP. Fonte: Instituto Geológico, 2014.

As trilhas interpretativas são caminhos preestabelecidos, com diferentes formas, larguras e tamanhos, que tem o objetivo de colocar o turista em contato com a natureza, ou conduzi-lo a um caminho específico, possibilitando o seu entendimento do meio natural através dos meios interpretativos como placas, painéis, folhetos (em geral nas trilhas autoguiadas) e/ou pela comunicação com guias turísticos e monitores ambientais, durante o percurso das trilhas guiadas (FOLMANN et al., 2010). No contexto das UC no Brasil é muito comum o percurso de trilhas para se chegar ao local que se pretende visitar, porém, na maioria das vezes são poucas informações oferecidas ao visitante restringem-se apenas a informações de localização e em alguns casos a informações sobre a biodiversidade (Figura 3.3.3a/b). No caso das trilhas guiadas, na maioria das vezes, as informações abordadas pelos condutores referem-se também aos aspectos biológicos e em alguns casos aos aspectos histórico-culturais. 

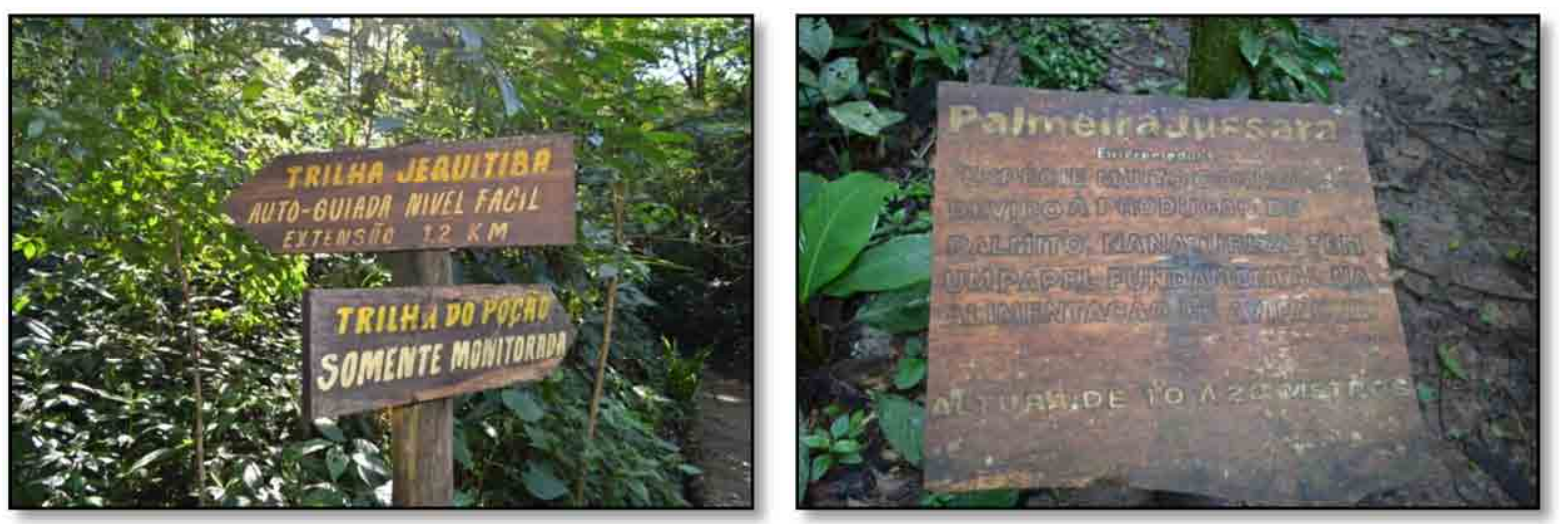

Figura 3.3.3 - a) Placa de sinalização da Trilha do Jequitibá e Trilha do Poção no Núcleo Caraguatatuba do PESM, b) Ao longo da Trilha do Jequitibá são encontradas placas sinalizando importantes elementos da biodiversidade local, como a palmeira Jussara, onde se extrai o palmito, que representa um importante ingrediente da gastronomia local (Fotos: Maria da Glória Motta Garcia).

Quanto aos roteiros geoturísticos ou geológicos, estes são constituídos por diferentes pontos de interesse geológico que exemplificam diferentes processos e eventos geológicos. Estes pontos podem ser inseridos em percursos preexistentes ou podem ser criados a partir de uma temática, como exemplo, podemos citar o "Passeio Geológico da Foz do Douro" no Porto, Portugal. O complexo metamórfico da Foz do Douro foi classificado como Patrimônio Natural Municipal em 2001, após a proposta da Universidade do Porto para este roteiro ser aprovada pela Câmara Municipal. O roteiro foi inaugurado em 2005 e é composto por diferentes afloramentos marcados por painéis interpretativos, os quais "explicam" diferentes processos geológicos registrados nas rochas ao longo da costa (Figura 3.3.4a/b). Além disso, o passeio conta ainda com um centro de visitantes, onde se pode adquirir folhetos e um livro descritivo sobre o roteiro. 

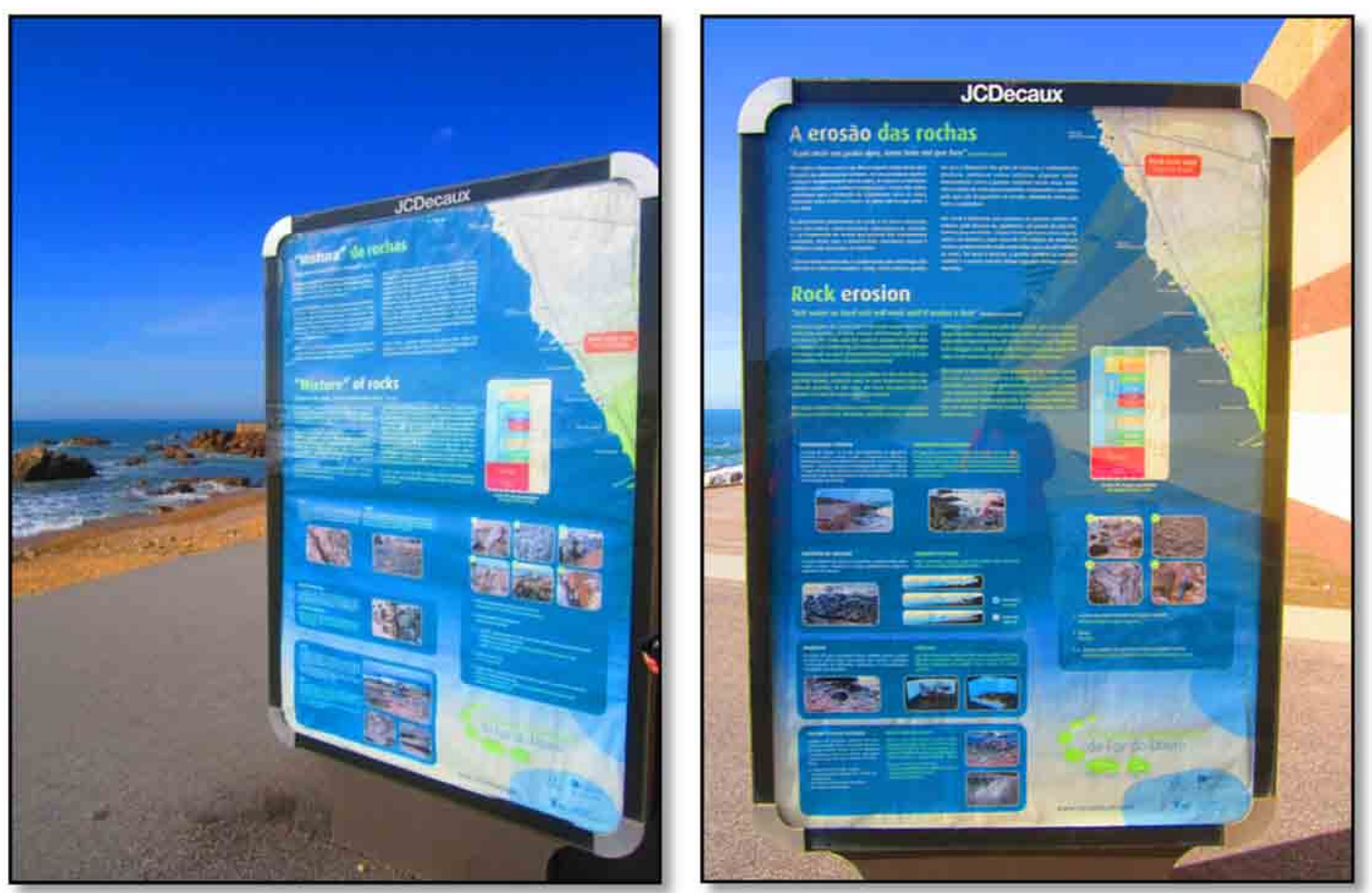

Figura 3.3.4 - a) e b) Painéis interpretativos do Passeio Geológico da foz do Douro, Portugal.

Pode-se ainda realizar cursos direcionados a guias turísticos e monitores ambientais com a finalidade de fornecer a esses condutores informações teóricas e práticas sobre a geodiversidade local e a interpretação geológica. Assim a mediação entre esses condutores e turistas pode ser enriquecida, pela "transmissão" do conhecimento geocientífico de maneira apropriada. Aliada e esta prática pode-se ainda elaborar em conjunto com as UC exposições sobre o patrimônio geológico local em centros de visitantes.

A fim de fomentar o geoturismo local, além do uso adequado dos meios interpretativos é necessário que haja o envolvimento dos distintos setores comerciais, como hoteleiro, gastronômico e artesanal. Neste sentido, é necessário que os empresários tenham conhecimento sobre as questões relacionadas à geodiversidade e a geoconservação.

No que diz respeito ao setor artesanal, uma possível alternativa em Ubatuba é a introdução destes conceitos e junto a Casa do Artesão, que é uma associação local iniciada em 2005, que além da geração de renda tem como objetivo preservar a cultura do artesanato local. Atualmente, esta associação conta com uma loja 
própria e mais de trinta e seis artesãos que vendem diversos produtos feitos a mão, como bonecas de panos, peças decorativas, brinquedos, bijuterias, instrumentos musicais, cerâmicas, artefatos de madeira, mosaico, fibra de bananeira, entre outros (SULFOGRAFIA, 2014) (Figura 3.3.5a/b). Além disso, os associados aceitam encomendas, para hotéis, restaurantes, pousadas e lojas de decoração, o que pode contribuir com a introdução de novos produtos nesse setor comercial, porém, com um viés geocientífico.

Nos demais setores comerciais, a introdução e divulgação das questões sobre a geodiversidade podem ser inseridas por meio de palestras e eventos, em parceria com a administração local e os próprios núcleos admirativos das UC, que exercem um importante papel na comunicação entre tais setores comerciais e turistas. O estabelecimento dessas parcerias é prevista e viabilizada pelo Plano de Manejo do PESM e, em alguns locais, como o Núcleo Santa Virgínia e a Prefeitura de São Luiz do Paraitinga as ações realizadas referem-se principalmente na capacitação de monitores e realização de atividades de educativas com as escolas locais em parceria com ONG's da região (MATOSSO, 2006).
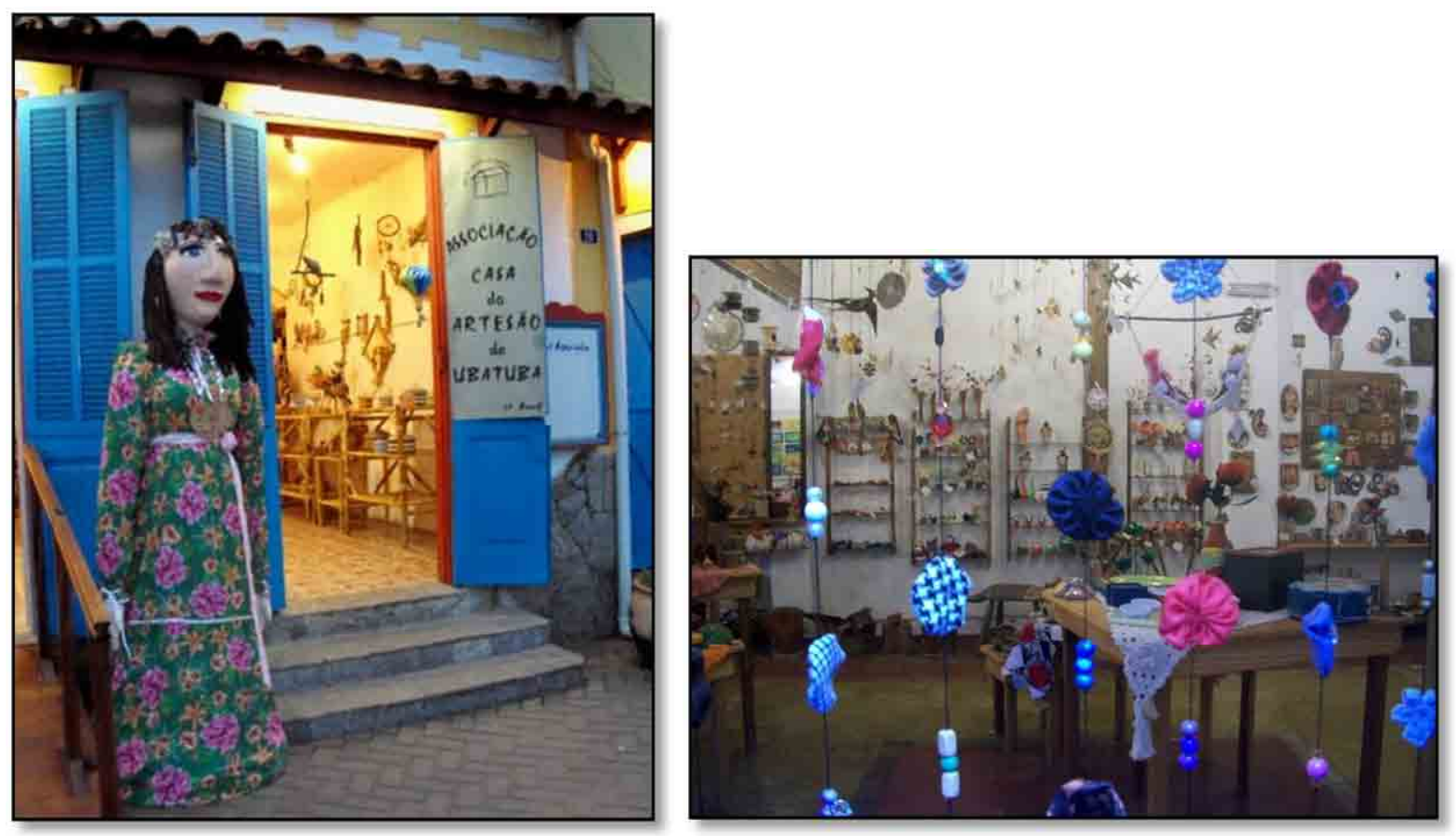

Figura 3.3.5 - a) Vista para a entrada da associação Casa do Artesão de Ubatuba, b) artesanatos expostos para venda no interior da casa. Fonte: Sulfografia (2014) e Casa do Artesão (2014). 


\section{CAPÍTULO 4. GEODIVERSIDADE DO MUNICÍPIO DE UBATUBA}

\subsection{Características Fisiográficas}

Conforme apresentado no capítulo 1, a área de estudo deste trabalho corresponde ao Município de Ubatuba, situado no litoral norte do estado de São Paulo. De modo geral, esta região destaca-se por suas características fisiográficas que compõem belíssimos cenários naturais, os quais são densamente procurados para prática do turismo.

No que diz respeito às características físicas, a região abrange duas unidades geomorfológicas distintas: a Serra do Mar e a Planície Costeira. A Serra do Mar corresponde à escarpa montanhosa da borda oriental do Planalto Atlântico, sendo suas direções geográfica e estrutural SW/NE típicas do litoral sudeste brasileiro, apresentando desníveis médios de 1.000 metros em larguras entre 5 e $10 \mathrm{Km}$ e se estendendo por $1.000 \mathrm{Km}$ desde o Estado do Rio de Janeiro até o Estado de Santa Catarina, (SANTOS, 2004).

A Planície Costeira é uma unidade geomorfológica caracterizada por apresentar relevo plano gerado por processos litorâneos. São terrenos de distribuição contínua ao longo da orla marítima. Apresenta baixa altitude, próxima ao nível do mar, com sistema de drenagem de baixa densidade, de padrão meandrante, pois os cursos dos rios chegam a seu final neste ambiente. Em certos locais podemse reconhecer padrões do tipo anastomosado, como no caso dos mangues (sujeitos à ação das marés). Muitas vezes sobressaem-se na fisiografia aplainada morros cristalinos isolados (PONÇANO et al. 1981).

A Planície Costeira corresponde à área do estado drenada diretamente para o mar, constituindo o rebordo do Planalto Atlântico. É em maior parte uma região serrana contínua, que à beira-mar cede lugar a uma sequência de planícies de variadas origens (PONÇANO et al. 1981).

Os domínios da Serra do Mar estão incluídos na floresta tropical úmida. A Mata Atlântica, segundo Santos (2004), é cientificamente denominada de Floresta Ombrófila Densa ou Floresta Atlântica de Encostas. Suas principais características são: grande diversidade florística, grande endemismo de espécies, árvores com até 
30 metros de altura, corpo florestal denso com copas contínuas, ambiente interno sombreado e abafado, dentre outras. O território municipal de Ubatuba ocupa $710,783 \mathrm{~km}^{2}, 83$ por cento dos quais estão encobertos pela Mata Atlântica e localizados no Parque Estadual da Serra do Mar: Núcleo Cunha - Indaiá, Santa Virgínia e Picinguaba.

No que se refere ao clima do litoral norte de São Paulo, é controlado por massas tropicais e equatoriais, caracterizado por alta umidade e quente. A região que se estende de São Sebastião a Ubatuba, no que se refere à pluviosidade, nas planícies costeiras a precipitação média de 1800 a 2500 mm (ANDRADE \& CUNHA, 2010; SOUZA, 2012).

\subsection{Contexto Geológico}

O Município de Ubatuba está inserido no Domínio Costeiro do Terreno Serra do Mar, que faz do sistema orogênico da Província Mantiqueira. A seguir apresentase o contexto geológico o qual a área enfocada se insere partindo de uma escala regional a uma escala local, com destaque para os principais elementos da geodiversidade de Ubatuba.

\subsubsection{Província Mantiqueira}

Almeida et al. (1977, 1981) aplicaram para o Brasil o conceito de províncias estruturais, identificando 10 maiores províncias (Figura 4.2.1.1). $O$ estado de São Paulo está situado na Província Mantiqueira. Esta província estrutural situa-se a leste dos crátons São Francisco e Rio de La Plata/Paraná, tem idade neoproterozoica a inicio do Paleozoico e estende-se por cerca de $300 \mathrm{~km}$ com orientação NNE-SW ao longo da costa atlântica de Montevidéu (Uruguai) e ao sul da Bahia. Além de guardar uma longa e complexa evolução do Neoproterozoico na América do Sul (900-520 Ma), preserva também remanescentes de unidades paleotectônicas arquenas, paleoproterozoicas e mesoproterozoicas. Constitui juntamente com a extremidade meridional da Província Tocantins, o arcabouço précambriano do sudeste brasileiro. 


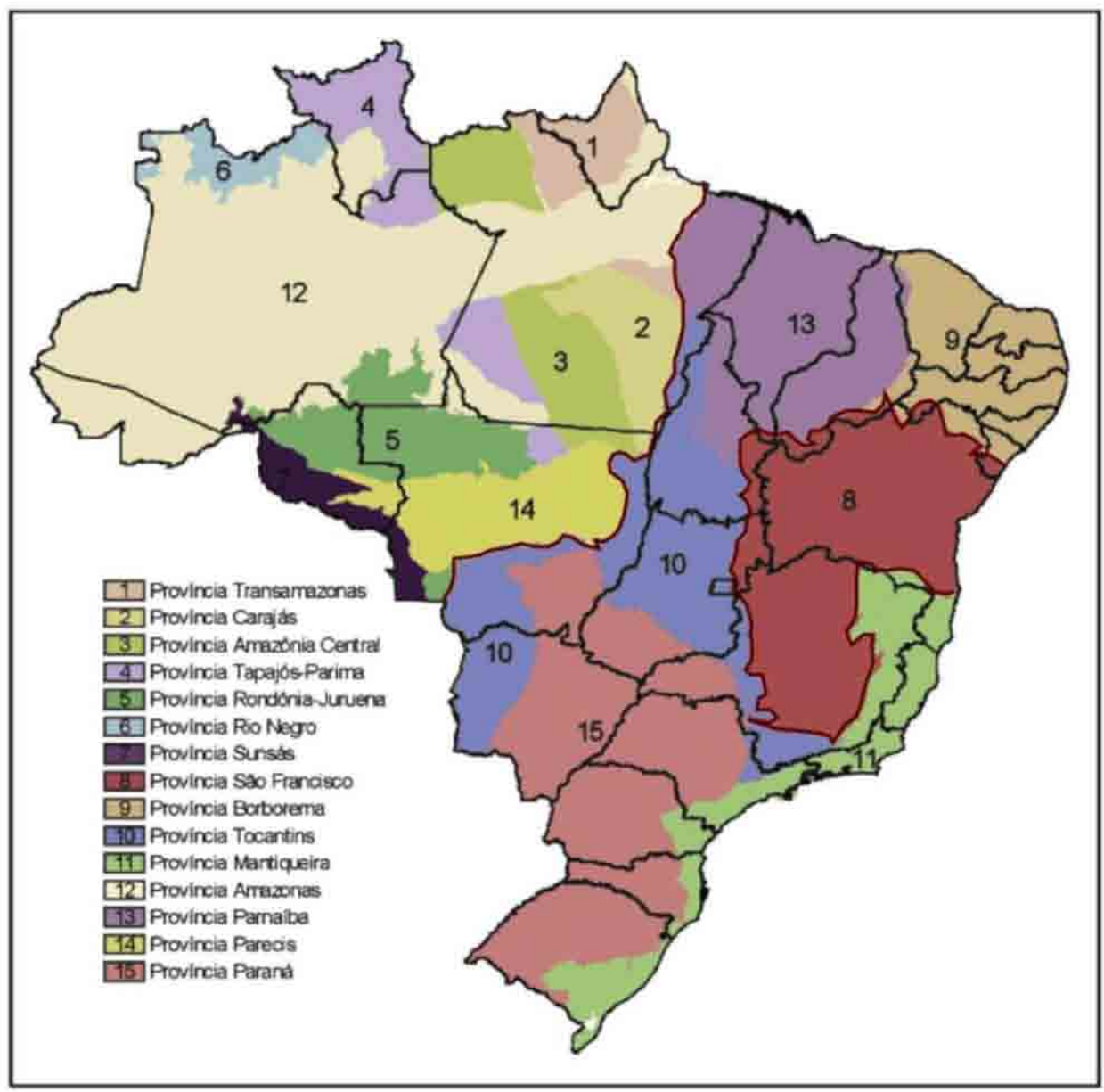

Figura 4.2.1.1 - Províncias estruturais Brasileiras. (BIZZI, et al. 2003).

A Província Mantiqueira é caracterizada por um sistema orogênico que inclui, de norte para o sul, os orógenos Araçuaí, Ribeira, Dom Feliciano e São Gabriel, e pela zona de interferência entre os orógenos Brasília e Ribeira (Figura 4.2.1.2). Desta zona de interferência para sul, até a borda norte do maciço cratônico de Luis Alves, estende-se um conjunto de unidades cujas relações geotectônicas com o Orógeno Ribeira são ainda dúbias e que, em parte, poderia pertencer à extremidade sul do Orógeno Brasília. Em função disto, estas unidades estão agrupadas nos terrenos Apiaí-Guaxupé e Embú (BIZZI, et al. 2003; HEILBRON et al., 2004).

A evolução geotectônica da Província é entendida por uma sucessão de cinturões de "empurrão e dobramento" controlados por distintos sistemas de cavalgamento em direção as margens cratônicas. A maioria destes cinturões corresponde a orógenos colisionais evoluídos diacronicamente durante 0 Neoproterozoico/Cambriano. Apenas o domínio central e no extremo sudoeste da província foram reconhecidos remanescentes de orógenos controlados por 
subducção. Além da extensiva granitogenêse, os orógenos são reconhecidos por suas sequências tectono-estratigráficas mistas de extensas bacias de margens continentais rifteadas e discreto registro de depósitos de assoalhos oceânicos, de arcos e retroarcos. Constituem, assim, um mosaico de terrenos Neoproterozoicos agregados há aproximadamente $560 \mathrm{Ma}$ quando deram origem ao Supercontinente Gondwana Ocidental (BIZZI, et al. 2003; HEILBRON et al., 2004; HASUI, 2010).

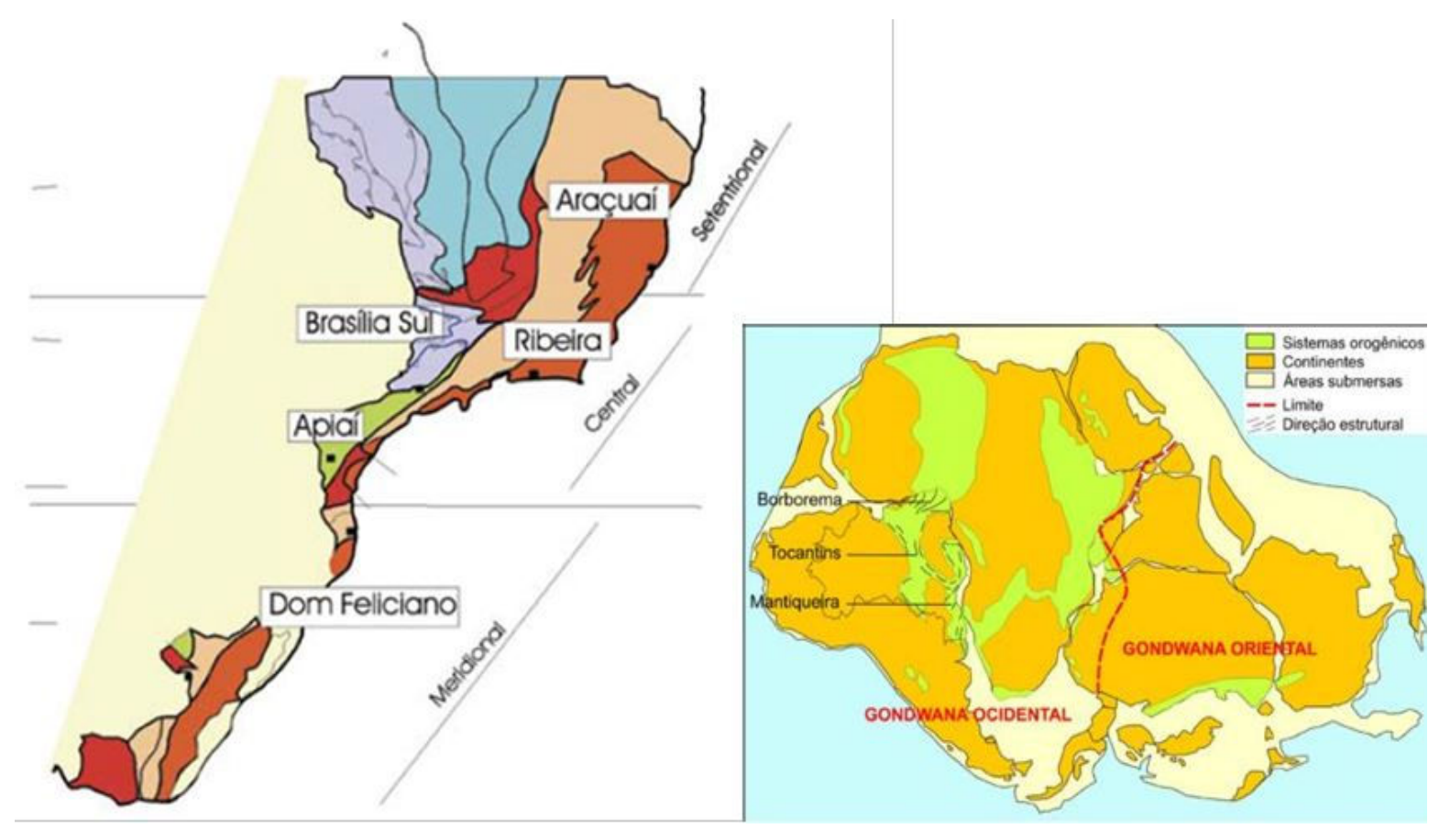

Figura 4.2.1.2 - a) Subdivisão do Sistema Orogênico Mantiqueira: o segmento setentrional é o Orógeno Araçuaí; o segmento central inclui a porção sul do Orógeno Brasília e os orógenos Ribeira e Apiaí; e o segmento meridional inclui os orógenos Dom Feliciano e São Gabriel. As cores roxo e laranja indicam os terrenos que alojam os arcos magmáticos neoproterozóicos (HEILBRON et al., 2004). No detalhe, as províncias estruturais brasileiras e a Província da Mantiqueira. Bizzi et al. (2003), modificado de Almeida et al., (1977); b) Configuração do Supercontinente Gondwana e localização das faixas móveis (HASUI, 2010). 


\subsubsection{A Faixa Ribeira}

O Orógeno Ribeira, no qual se insere a área enfocada, faz parte do sistema orogênico Mantiqueira (HEILBRON et al., 2004), de idade neoproterozóica (800-500 Ma). A origem deste Orógeno aparece como resultado da colisão entre as extremidades SSW da Placa do Congo Ocidental e o cráton São Francisco, além da amalgamação de microplacas e outros terrenos situados a sudeste deste cráton, que teve lugar entre 650-510 Ma (TROMPETTE et al., 1993; SCHMITT et al., 2004; HEILBRON et al., 2008, TUPINAMBÁ et al., 2012) no decorrer do Ciclo Orogênico Brasiliano-Pan-Africano. Os últimos eventos de colisão sobrepuseram à geometria inicial desses terrenos, cujos limites foram organizados como zonas de escala regional NE-SW, principalmente distrais de cisalhamento que, desde então, funcionaram como zonas de fraqueza, reativadas em níveis crustais mais rasos durante os eventos extensionais posteriores. A transição para condições de plataforma estável ocorreu no Siluriano-Devoniano (BRITO NEVES, 1999).

Do ponto de vista geotectônico, as porções central e norte da Faixa Ribeira são compartimentadas de acordo com os terrenos que compõem denominados: Ocidental, Parnaíba do Sul, Embu, Oriental - Serra do Mar e Cabo Frio (Figura 4.2.2.1), ou nos terrenos que correspondem ao Sistema de Orógenos Brasiliano II (BIZZI et al., 2003 - Figura 4.2.2.2). De acordo com Heilbron et al. (2004), os terrenos tectônicos são compostos pelas seguintes unidades lito-estratigráfica:

a) Embasamento arqueano e/ou paleoproterozóico mais velho que 1,7 Ga;

b) Sequências metassedimentares depositadas em bacias intracontinentais paleoproterozoicas a mesoproterozoicas;

c) Sequências metassedimentares e metavulcano-sedimentares neoproterozoicas que incluem sequências de margem passiva (abertura oceânica), sequências relacionadas ao fechamento de oceanos (bacias de ante-arco e retro-arco), e ao estágio da colisão continental (bacias molássicas e de antepaís);

d) Granitóides neoproterozoicos pré-colisionais, gerados em arco magmático intra-oceânico ou de margem continental ativa, e, portanto contemporâneos a processos de subducção;

e) Granitóides neoproterozoicos sincolisionais; 
f) Coberturas neoproterozoico-cambrianas associadas a bacias tardi-orogênicas e magmatismo pós-colisional.

O terreno Ocidental da Faixa Ribeira, corresponde à margem passiva retrabalhada do paleocontinente São Francisco, compreende as unidades do embasamento paleoproterozoicas e arqueanas retrabalhadas e sucessões sedimentares da margem passiva neoproterozoica (HEILBRON et al., 2004).

O terreno Paraíba do Sul e Embu foram amalgamados ao paleocontinente São Francisco entre 605 e $580 \mathrm{Ma}$, e é constituído por ortognaisses paleozoicos e sequencias metassedimentares.

O terreno Oriental - Serra do Mar teria sido acrescido ao paleocontinente 550-580 Ma (HEILBRON et al., 2008), é dividido em três domínios tectônicos, da base para o topo em uma seção NW - SE: domínios Cambuci, Costeiro e Italva (HEILBRON \& MACHADO, 2003).

O terreno Cabo Frio, corresponde ao ultimo estágio colisional, entre 535-510 $\mathrm{Ma}$, representado por associações ortognáissicas e sucessões metassedimentares de alto grau (SCHIMITT et al., 2000, 2004).

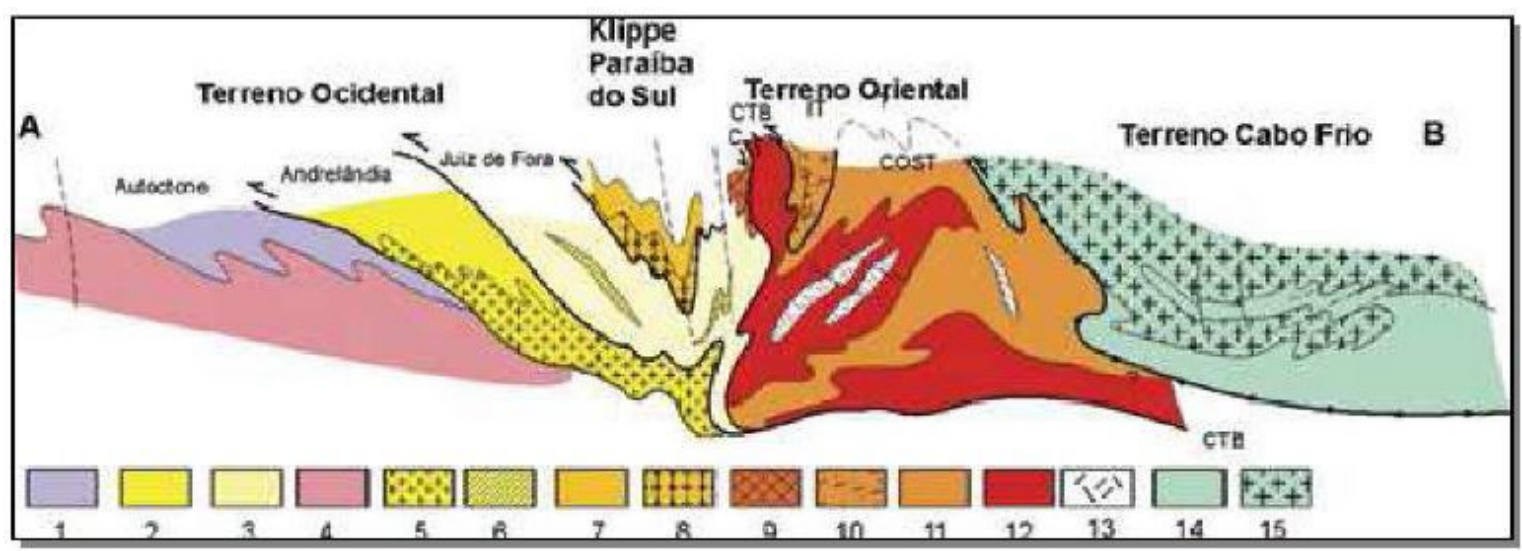

Figura 4.2.2.1 - Seção estrutural esquemática NWSE para o Orógeno Ribeira. Terreno Ocidental (1 a 6); terreno Paraíba do Sul (7 e 8); terreno Oriental (9 - sequencia Cambuci; 10 - sequencia Italva; 11 - sequencia costeiro; 12 - arco magmático Rio Negro; 13 granitos colisionais); terreno Cabo Frio (14 e 15). (Retirado de HEILBRON et al., 2004). 


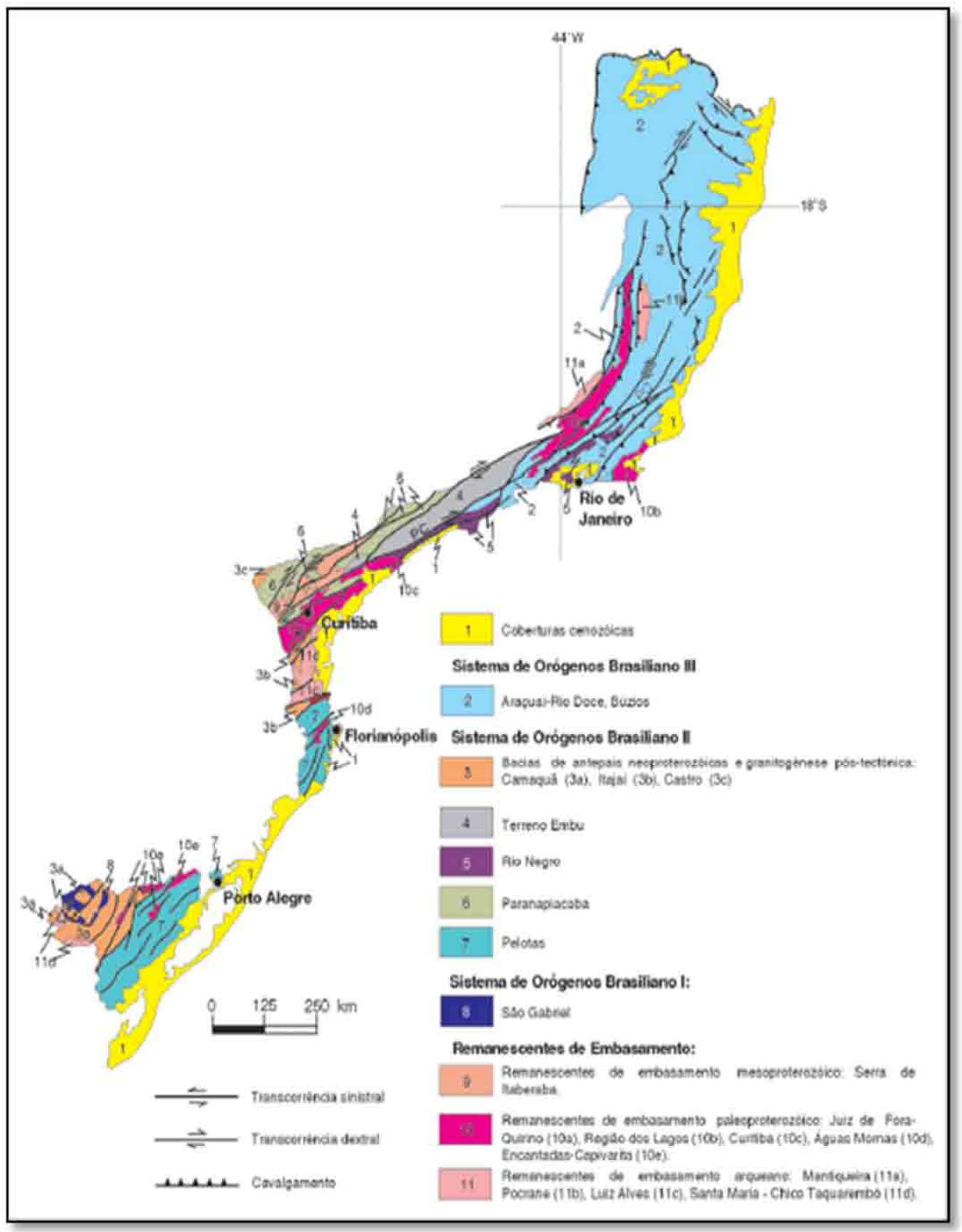

Figura 4.2.2.2. Domínios tectônicos e principais estruturas da Província da Mantiqueira (BIZZI et al., 2003).

\subsubsection{Terreno Serra do Mar (Domínio Costeiro)}

No estado de São Paulo encontram-se dois domínios dentro da Faixa Ribeira. Estes domínios são separados pela falha de Cubatão e são denominados Embu, a oeste e Serra do Mar (Domínio Costeiro), a leste. A área enfocada no presente 
trabalho se insere no Complexo (HASUI et al., 1981) ou Domínio (HEILBRON \& MACHADO, 2003) Costeiro (Figura 4.2.3.1).

O Domínio Costeiro representa um dos terrenos que convergiram durante a aglutinação do Supercontinente Gondwana e o ambiente onde se instalou o arco magmático da Faixa Ribeira, denominado Complexo Rio Negro. É composto principalmente por ortognaisses com filiação de arco magmático e por gnaisses metapelíticos parcialmente migmatizados, incluindo anfibolitos interpretadas como paleodiques, sendo todo o conjunto cortado por inúmeros corpos de composição granítica sin-a tardi-colisionais (CAMPANHA \& ENS, 1996, DIAS NETO et al., 2009, TUPINAMBÁ et al., 2012). Representa um dos terrenos que convergiram durante a aglutinação do supercontinente Gondwana, durante o Neoproterozoico / Cambriano (TUPINAMBÁ et al., 2007).

O mapa geológico da região do litoral norte do Estado de São Paulo (Figura 4.2.3.2) retirado da CPRM (2006) apresenta às unidades presentes na área enfocada.

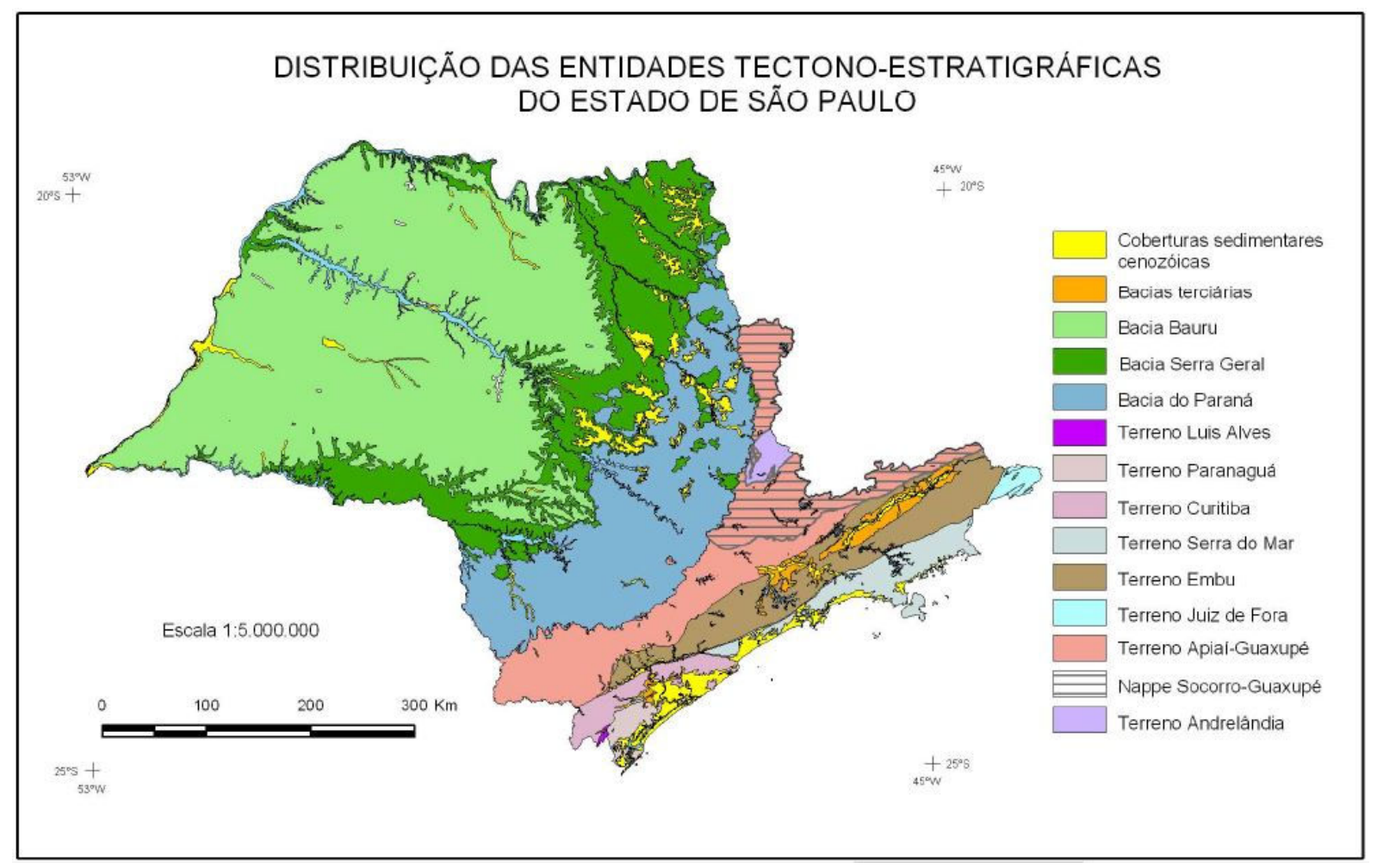

Figura 4.2.3.1 - Entidades tectono-estratigráficas do estado de São Paulo. Fonte: CPRM (2006). 


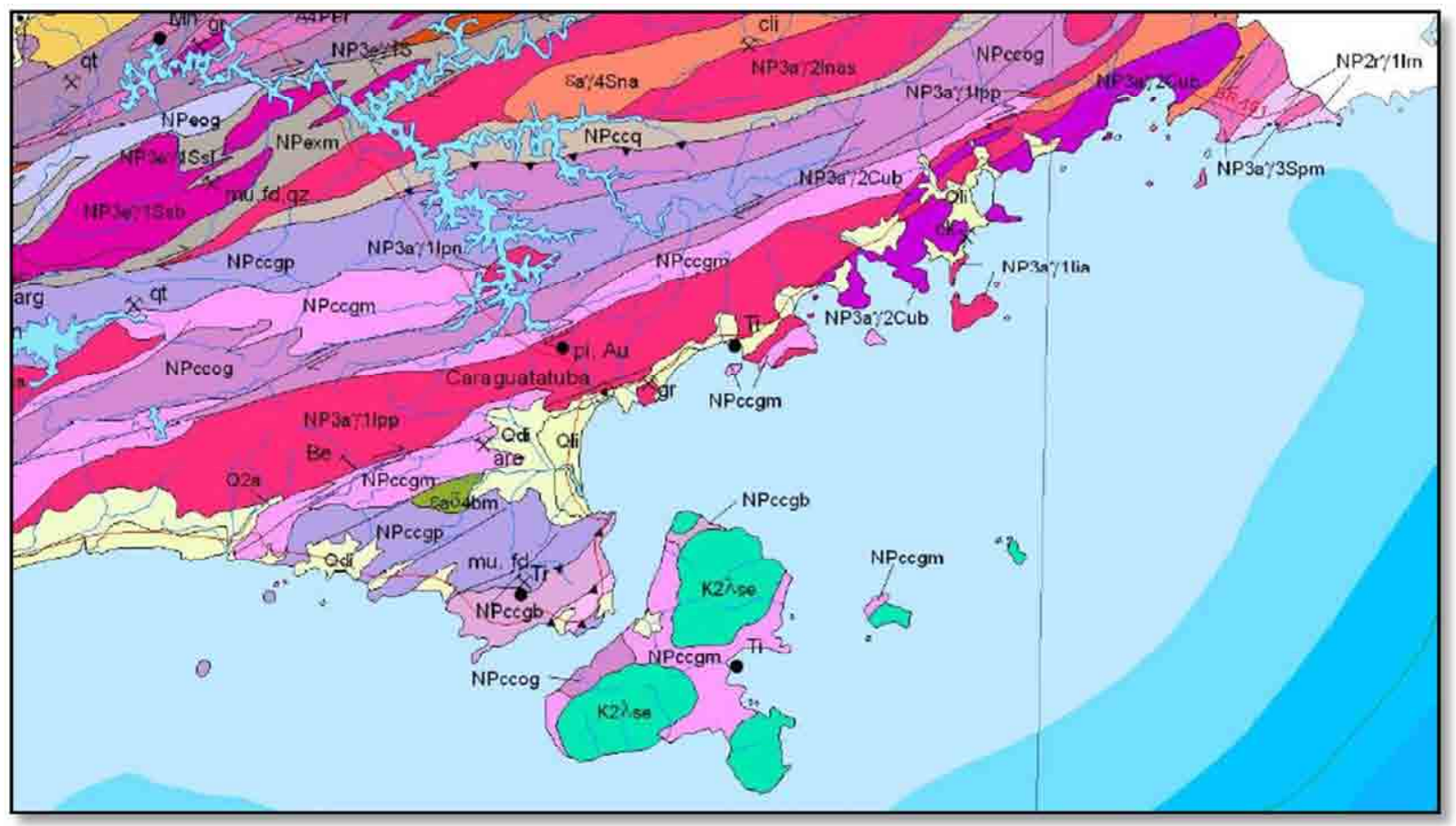

COMPLEXO COSTEIRO

NPccq Unidade quartzitica (NPccq): quartzito bandado, ro-

NPccq cha calcissilicática, granada-sillimanita-biotita-quartzo

NPccog xisto ou gnaisse; biotita gnaisse tonalito granodioritico

NPccgp Unidade ortognáissica (NPccog): ortognaisse migma-

NP ccgm títico cálcio-alcalino, (hornblenda)-biotita granitóide

gnáissico porfiróide e augen gnaisse

NPccgb Unnidade de gnaisses peraluminosos (NPccgp):

gnaisse kinzigítico com núcleos antigos como restitos

biotíticos, rocha calcissilicática e anfibolito $593-571 \mathrm{Ma}$

U-Pb SHRIMP (12)

Unidade granito gnáissica migmatitica (NPccgm):

hornblenda-biotita gnaisse granitóide porfiróide e augen gnaisse $647-578 \mathrm{Ma}$ U- $\mathrm{Pb}^{(3)}$

Unidade de gnaisses bandados (NPccgb): gnaisse migmatito de composição monzogranitica, com bandas quartzo-feldspáticas e máficas $612 \mathrm{Ma} \mathrm{U}^{-\mathrm{Pb}^{i(39]}}$

Complexos plutônicos alcalinos (K2 $\lambda$ ): Ipanema (i): ortoclasio-aegerinito, ortoclásio-lusitanito, umptekito e nordmarkito, shonkinito pórfiro, glimmerito, fenito, dunito, nefelina sienito, carbonatito; Passa Quatro (pq): nefelina sienito, foiaito $70 \mathrm{Ma} \mathrm{Rb}-\mathrm{Sr}{ }^{(29)}, 67 \mathrm{Ma} \mathrm{K}$ - $\mathrm{Ar}{ }^{(39)} ; \mathrm{Poços} \mathrm{de}$ Caldas (pc): aegirina fonólito, pseudofleucita fonólito, nefelina sienito, tufito de lápilli, brecha e aglomerado 90-86 Ma Rb-Sr ${ }^{(29)}$, Ponte Nova

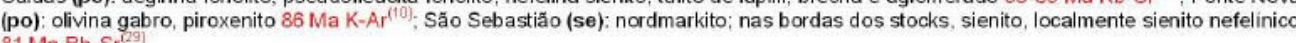
$81 \mathrm{Ma} \mathrm{Rb}-\mathrm{Sr}^{12}$

Complexos plutônicos alcalinos (K1 $\lambda$ ): Jacupiranga (ja); dunito, magnetita clinopiroxenito, flogopita clinopiroxenito, melteijito nefelina clinopiroxenito, nefelina-olivina clinopiroxenito, andesina-flogopita clinopiroxenito, localmente ijolito e carbonatito $130 \mathrm{Ma} K-\mathrm{Ar}^{(2)}$; Juquiá (ju): olivina clinopiroxenito, clinopiroxenito, nefelina sienito e ijolito, urtito e melteigito, subordinadamente carbonatito, olivina álcali-gabro e monzodiorito $133 \mathrm{Ma} \mathrm{K}-\mathrm{Ar}^{\left({ }^{(a)}\right.}$

$K_{\lambda}$ Intrusões alcalinas indiscriminadas $(K \lambda)$ : sienito, peridotito, piroxenito

Figura 4.2.3.2 - Mapa geológico da região do litoral norte do estado de São Paulo. Fonte: CPRM (2006). 
Os diferentes terrenos tectono-estratigráficos quem compõem a Faixa Ribeira registram as diferentes fases tectônicas ao longo da sua história geológica. Diversos autores (HEILBRON et al., 1995, 2000; TROUW et al., 2000 apud MAGALHÃES, 2012) por meio da interpretação de dados estruturais, metamorfismo e magmatismo, sugerem a ocorrência de três eventos deformacionais e dois eventos magmáticos.

O primeiro evento deformacional, de idade Neoproterozóica (595-565 Ma), desenvolveu estruturas como dobras assimétricas, foliação principal, zonas de cisalhamento com formação de milonitos e lineação de estiramento e lineações de minerais, registradas nas regiões da Serra do Mar em condições de temperaturas máximas (HEILBRON, 1995; MAGALHÃES, 2012). O Segundo evento deformacional é interpretado como deformações tardias, que redobraram a xistosidade principal e resultou em uma deformação compressiva no início do Paleozóico (540-520 Ma) gerando dobras com eixos NE/SW e zonas de cisalhamento tipo trend NE (TUPINAMBÁ et al., 2007). O terceiro evento gerou dobras e crenulações, com planos axiais subverticais e eixos N-S, associadas às zonas de cisalhamento dúcteis e rúpteis. Esse evento é provavelmente, associado ao colapso do Orógeno (HEILBRON et al., 1995, 2000; TROUW et al., 2000 apud MAGALHÃES, 2012).

No início do Cretáceo ( $130 \mathrm{Ma}$ ) sobreveio à reativação da Plataforma Brasileira (ALMEIDA, 1969), caracterizadas por processos extensionais relacionados com a fragmentação do Pangea, do Gondwana e a abertura do Oceano Atlântico no Jurássico Superior/ Cretáceo Inferior (HASUI, 2010). O processo de abertura do Atlântico foi acompanhado por eventos magmáticos, incluindo a Província Magmática Paraná, representados por diques básicos e intermediários, cuja colocação foi controlada pelas estruturas neoproterozóicos e pela Junção Tríplice do Paraná (GARDA \& SCHORSCHER, 1996, COUTINHO, 2008).

O magmatismo alcalino, na porção meridional da Plataforma Sul-Americana foi condicionado a zonas de falhas, arcos e flexuras reativadas nas bordas das bacias, principalmente na Bacia do Paraná e apresenta intrusões alcalinas de ocorrência do Cretáceo Superior ao Paleoceno inferior, que constituem a Província Alcalina da Serra do Mar (RICCOMINI et al. 2005; AZZONE et al., 2009). Esse magmatismo manifesta-se por vulcanismo basáltico de caráter toleítico, com 
derivados ácidos e por enxames de diques na borda da bacia, que se estenderam até a área da bacia de Santos (AZZONE et al., 2009).

O enxame de diques da Serra do Mar ocorre nas regiões costeiras entre Santos e o Espírito Santo Estendendo-se para o interior até a região do Vale do Paraíba (GARDA, 1995; GARDA \& SCHORSCHER, 1996). Diversos autores demostram que as ocorrências de diques máficos e ultramáficos encontrados entre os estados de São Paulo e Rio de Janeiro e apresentam orientação SW/NE subverticais. (VALENTE, 1997; COUTINHO, 1992, 2008; GARDA, 1995; GARDA \& SCHORSCHER, 1996). Esses diques tem composição, predominantemente toleítica ou alcalina e estão associados à fragmentação do Supercontinente Gondwana no Cretáceo Inferior (132 Ma) cuja principal fase de intrusão ocorreu entre 133-129 Ma coincidentes com as intrusões do Arco Ponta Grossa (TURNER ${ }^{10}$ et al., 1994; DECKART ${ }^{11}$ et al., 1998 apud Silva, 2010).

Durante o Paleógeno desenvolveu-se o Rift Continental do Sudeste do Brasil (RCSB), que se estende do Paraná até o Rio de Janeiro. Segundo Riccomini (1989) o RCSB é uma depressão alongada com aproximadamente $900 \mathrm{~km}$ de comprimento que compõe um sistema de bacias trafogênicas que foram instaladas no domínio da Faixa Ribeira, de idade neoproterozoica, durante o Cenozóico (55 - $11 \mathrm{Ma)}$ ). rift foi ativado por uma série de eventos magmáticos alcalinos no Mesozóico - Cenozóico (82 - 52 Ma) (RICCOMINI et al., 2004). Durante a separação mesozoica, inúmeras descontinuidades crustais neoproterozoicas foram reativadas, devido a movimentos extensionais e verticais, tais como falhas normais, foi responsável por rifteamento inicial e elevação dos blocos adjacentes, como as serras do Mar e da Mantiqueira, caracterizando um escarpamento duplo que reflete uma evolução composta relacionada a processos distintos, tais como reativação de antigas estruturas neoproterozoicos e formação do rift (HIRUMA et al., 2010).

10 TURNer, S., REgelous, M., KELLEY, S., HAWKESWORTH, C., MANTOVANI, M. 1994. Magmatism and continental break-up in the South Atlantic: high precision 40Ar/39Ar geochronology. Earth and Planetary Science Letters, Netherlands, v. 121, p. 333-348.

${ }^{11}$ DECKART K., FÉRAUD G., MARQUES L.S., BERTRAND H. 1998. New time constraints on dyke swarms related to the Paraná-Etendeka magmatic province, and subsequent South Atlantic opening, southeastern Brazil. Journal of Volcanology and Geothermal Research, Netherlands, v. 80, p. 67-83. 


\subsection{Geodiversidade o Município de Ubatuba}

A história geológica do litoral norte do estado de São Paulo se insere no contexto do Supercontinente Gondwana, aglutinado durante o Ciclo Brasiliano, Neoproterozoico-Cambriano e fragmentado Jurássico-Cretáceo. A reativação Mesozóica (ALMEIDA, 1972) que resultou na abertura do Atlântico foi acompanhada pela configuração da Serra do Mar no início do Paleógeno e da Planície Costeira. Sendo assim, a geodiversidade de Ubatuba registra os diferentes eventos tectônicos ao longo dessa história geológica.

O Domínio Costeiro na região de estudo é denominado Complexo Ubatuba (NEUMANN, 1993; GARDA, 1995). E é constituído pelas rochas charnockíticas e afins, granitos gnáissicos e leucogranitos e migmatitos geralmente oftalmíticos. As rochas afloram indistintamente na base da escarpa da Serra do Mar. A faixa charnockítica se estende a $20 \mathrm{~km} \mathrm{NE}$ da cidade de Caraguatatuba, prosseguindo em direção ao estado do Rio de Janeiro, com direção N60E, 50 km de comprimentos e largura estável de 3 a $7 \mathrm{Km}$, ocorrendo de modo descontínuo, sendo cortada por aluviões e sedimentos litorâneos (GARDA, 1995).

O charnockito é descrito por Neumann (1993: 29) como "uma rocha equigranular a porfirítica, de granulometria de matriz média a grossa, onde os megacristais, de ortoclásio mesopertítico, raramente ultrapassam 10mm. Exibe uma típica cor verde garrafa escura, com variações de tons acastanhados ou acinzentados. Normalmente a mudança de cor é devida à alteração”. Os charnockitos apresentam de 3 a $10 \%$ de máficos em seu volume total, visíveis apenas quando a alteração descolore um pouco a rocha e permite que se observem os máficos. Em geral, é uma rocha pouco foliada. A foliação é dada pelos minerais máficos, não ocorrendo de forma homogênea na rocha, sendo apenas reconhecível em partes mais alteradas (NEUMANN, op. cit.; AZEVEDO SOBRINHO et al., 2011).

Neumann (1993) reconhece na região de Ubatuba seis corpos lenticulares de charnockito, em geral em contato transicional com um hornblenda-biotita granito, sendo intrusivas em rochas de composição granítica e gnáissica. O corpo principal, que aflora no município tem aproximadamente em $250 \mathrm{~km}^{2}, 50 \mathrm{~km}$ na extensão WSW-ENE, e em média $5 \mathrm{~km}$ de largura. As lentes menores somam menos de 15 $\mathrm{Km}^{2}$. 
A unidade aflorante em Ubatuba, mineralogicamente compõe-se de ortoclásio micro e mesopertítico representa entre 30 e $60 \%$ dos minerais félsicos, plagioclásio ocorre, entre os félsicos, de 15 a $35 \%$, situando-se com maior frequência $20 \%$. E o quartzo, de 15 a $40 \%$ dos minerais félsicos presentes. Estes minerais representam mais de $90 \%$ do volume total da rocha. Minerais como hastingsita, ferrossilita, zircão, apatita e opacos (magnetita e ilmenita) aparecem como minerais acessórios comuns. Biotita é frequente, e hedenbergita pode ocorrer. Allanita e titanita são acessórios raros (NEUMANN, 1993).

Diversos autores (GASPARINNI e MANTOVANI, 1979; EBERT, 1968; FREITAS, 1976, GARDA, 1995) atribuem a origem das rochas charnockíticas datadas em 565 Ma por U-Pb (zircão) ID-TIMS de zircão (AZEVEDO SOBRINHO, 2011) e afins como magmática, sendo produto da fusão parcial das rochas de alto grau da crosta. Em seguida, essas rochas, teriam sido submetidas a metamorfismo regional da fácies granulito e subsequente migmatização, possivelmente à orogênese transamazônica. Posteriormente, submetidas á remagmatização e à feldspatização, em condições provável fácies anfibolitos durante o Ciclo Brasiliano (GARDA, op. cit.). Neumann (1993) afirma que a cristalização do charnockito ocorreu sob condições de temperatura e pressão de $850+/-50^{\circ} \mathrm{C}$ em ambiente tarditectônico.

A região de Ubatuba inclui a Ilha Anchieta, que geologicamente, é composta predominantemente por um quartzo monzogranito, intrusivo ao charnockito Ubatuba, datado em 500 Ma (U-Pb em zircões, AZEVEDO SOBRINHO et al., 2011) (Figura 4.3.1). Na porção mais ocidental ocorre uma faixa de charnockitos foliados e leucogranitos associados ao charnockito Ubatuba.

O Monzogranito Ilha Anchieta representa um dos registros meridionais dos estágios finais da Orogenia Búzios, o ultimo evento orogênico antes da abertura do Atlântico Sul (SCHIMITT, 2001; et al., 2004), o que justifica sua importância na geodiversidade associada ao Supercontinente Gondwana na região (GARCIA, 2012). Estes processos foram marcados por fraturamento onshore e offshore, seguido por intenso magmatismo que ocorreu como enormes derrames basálticos e como corpos toleíticos e alcalinos que compõem o Enxame de Diques da Serra do Mar (THOMPSON et al., 1998 ). Estudos indicam que o magmatismo toleítico é mais 
antigo ( 190-130 Ma) e relacionado com as fases iniciais do rifteamento, enquanto que as rochas alcalinas ( 80-70 Ma) são associadas à migração do Plume de Trindade e aos eventos cenozóicos responsáveis pela configuração da costa e formação de bacias terciárias (GUEDES et al., 2005, VALENTE et al., 2007). Dados de campo sugerem que as estruturas frágeis estão relacionados a um campo de tensões associado a um sinistral binário orientado ENE-WSW, com $\sigma \mathrm{HMax}$ a NNESSW e oHmin em SSE - WNW (HIGA, 2011), consistentes com dados regionais.

As rochas básicas do enxame de diques da Serra do Mar que afloram em Ubatuba foram estudadas por Turner et al. (1994) e Deckart et al. (1998). Estes estudos indicam que os diques de diabásio de Ubatuba têm idades 135 e $130 \mathrm{Ma}$, do Cretáceo Superior, que são equivalentes aos derrames basálticos da Bacia do Paraná que ocorreram entre 137 e 127 Ma (TURNER et al., op. cit.).

Para Garda (1995) apud Mello (2008) os diques básicos e intermediários da região entre as cidades de São Sebastião e Ubatuba, apresentam características similares aos da Bacia do Paraná; o evento que resultou na formação e variedade dos lamprófiros representa uma transição de magmas alcalinos para magmas de afinidade carbonática. Na região entre São Sebastião e Ubatuba, incluindo as ilhas, o litoral sul do estado de São Paulo e do estado do Rio de Janeiro, passou por dois eventos alcalinos importantes, um relacionado à geração de uma suíte de lamprófiros máficos e ultramáficos, e outro relacionado ao magmatismo intrusivo das ilhas de São Sebastião, Búzios e Vitória. Os diques básicos foram colocados em regiões de falhas das rochas encaixantes, deixando abertas passagens para manifestações do magmatismo alcalino (GARDA, 1995; MELLO, 2008).

\subsubsection{Os valores da Geodiversidade de Ubatuba}

A geodiversidade de Ubatuba, além dos aspectos geológicos descritos, inclui ainda, os valores econômicos, históricos e culturais. No município são encontradas antigas construções do período colonial, comunidades tradicionais quilombolas e caiçaras descendentes dos índios Tamoios e Tupinambás. As comunidades tradicionais através de sua memória desempenham um papel fundamental na reconstrução do imaginário cultural de Ubatuba. Embora não existam muitos registros escritos, Droguett e Fonseca (2005) afirmam de parte dessa história é 61 
contada de pais para filhos, geração para geração, como forma de preservar os costumes e tradições do povo caiçara.

Além disso, o charnockito Ubatuba representa grande importância histórica e econômica na região. Conhecido comercialmente como "granito verde Ubatuba" durante a década de 80, foram extraídos grandes volumes de rochas, que eram exportados principalmente para o Japão e Itália. Reconhecem-se pelo menos 160 locais de antigas extrações de charnockitos. Dentre eles, cerca de 20 foram visitados em atividades de campo durante o desenvolvimento deste trabalho. Os dados obtidos em campo e pela compilação de trabalhos anteriores resultaram na escolha do geossítio apresentado no capítulo seguinte (capítulo 5).

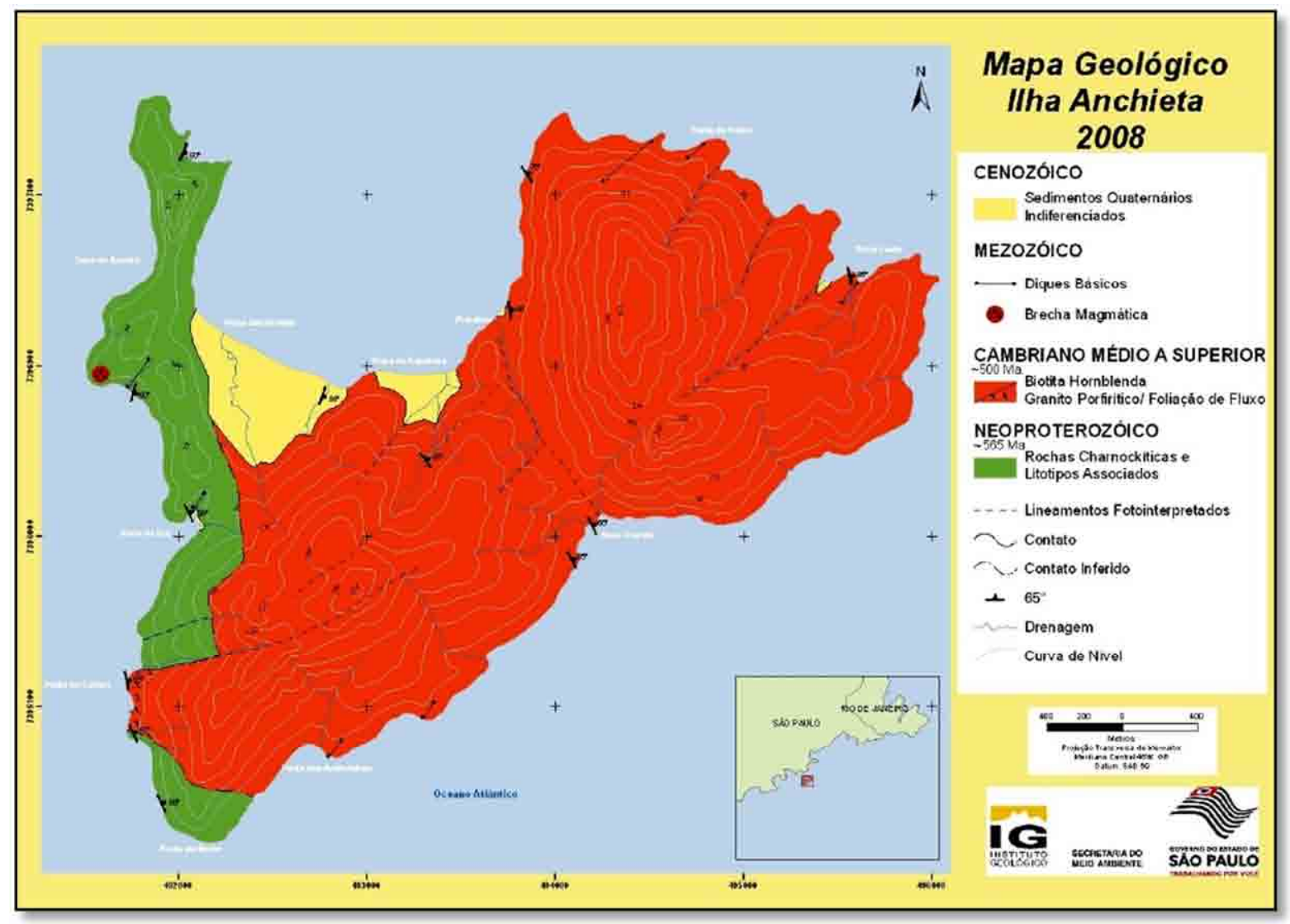

Figura 4.3.1 - Mapa Geológico da Ilha Anchieta. Fonte: Instituto Geológico, São Paulo. 


\section{INVENTÁRIO DO PATRIMÔNIO GOLÓGICO DE UBATUBA}

O inventário do patrimônio geológico é a primeira etapa de uma estratégia de geoconservação. Esta etapa representa a identificação, seleção e caracterização sistemática dos elementos da geodiversidade que se pretende proteger (BRILHA, 2005).

O inventário do patrimônio geológico de Ubatuba foi realizado considerando como principal caráter geocientífico os eventos que nos remete a amalgamação, a evolução e a fragmentação do Supercontinente Gondwana. Ademais, foram considerados os aspectos históricos, culturais e turísticos da região.

$\mathrm{Na}$ região enfocada foram, preliminarmente, identificados dez geossítios (Figura 5.1). Estes foram agrupados de acordo com o interesse geológico principal e associação com os eventos na história do Gondwana Ocidental: os geossítios "Pedra do Sino de Ubatuba", na Praia Santa Rita, "Charnockito Ubatuba", na Praia do Prumirim, "Praia do Cedro" e "Ponta Aguda" foram agrupados com o interesse ígneo, metamórfico e tectônico e representam principalmente os eventos da fase de aglutinação do Supercontinente durante o Neoproterozoico-Cambriano. O geossítio "Monzogranito Ilha Anchieta", na Ilha Anchieta, de interesse ígneo e tectônico, registra os estágio finais desta aglutinação, representados pela Orogenia Búzios, o último evento antes da abertura do Atlântico Sul. O Geossítio "Gruta que Chora", na Praia da Sununga tem como interesse ígneo e tectônico, representa tanto a fase de aglutinação quanto à fase de fragmentação do Supercontinente. Os geossítios "Brecha magmática Ilha Anchieta", "Xenólitos do manto e cones de explosão" na Praia Vermelha do Centro, e "Pico do Corcovado", de caráter essencialmente geomorfológico representam a fase de fragmentação do Gondwana, no JurássicoCretáceo. Estes geossítios têm como interesse principal o tectônico, pois ilustram os eventos extensionais que caracterizam a reativação da Plataforma Brasileira que perdurou até a abertura do Oceano Atlântico (Capítulo 4) (HASUI, 2010). Finalmente, o geossítio Mineração Itamambuca, na Praia de Itamambuca, remonta à história de extração do "Granito Verde Ubatuba", uma importante rocha ornamental da região. 


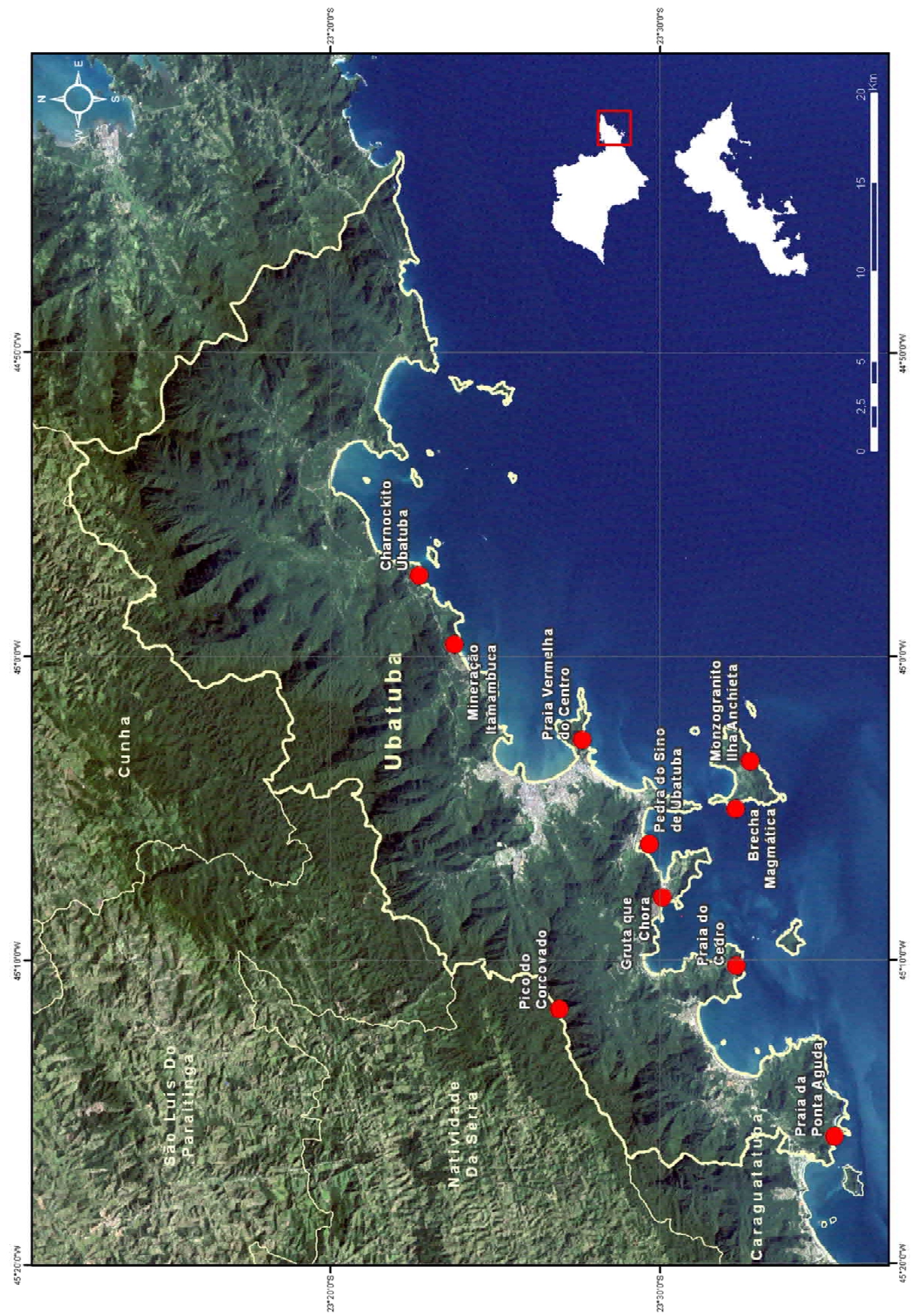

Figura 5.1 - Mapa de localização dos geossítios inventariados em Ubatuba. Autor: Carlos Mazoca. Fonte: Google ${ }^{\circledR}$ in Arcgis. 


\subsection{Geossítios inventariados}

A seguir apresenta-se a descrição sucinta de cada geossítio. Optou-se por utilizar o modelo descritivo que compreende os dados de localização e acesso, tipo de local (ponto, área ou seção), dimensão, unidade no mapa da CPRM (2006), justificativas do valor científico, elementos de interesse e uso potencial de cada geossítio. Adicionalmente foram acrescentadas as informações dos tipos litológicos observados em campo.

\subsubsection{Geossítio Charnockito Ubatuba}

Localização (UTM): $0504572 / 7414538$ (Figura 5.1.1.1).

Tipo: Ponto

Acesso: O geossítio está localizado no costão esquerdo da Praia do Prumirim, localizada a $19 \mathrm{~km}$ do centro de Ubatuba, sentido norte. O acesso se dá por via secundária no km 29 da Rodovia Rio - Santos (BR101). Chega-se à praia por uma estrada passando pela portaria do condomínio Prumirim, onde havia uma antiga vila caiçara.

Dimensão: Trata-se de uma laje mais elevada, com cerca de 30 metros e outro na altura da praia que se estende por aproximadamente 100 metros.

Unidade no mapa da CPRM (2006): NP3ay2Cub - Charnockito Ubatuba.

Principais litotipos observadas no geossítio: Charnockito Ubatuba. 


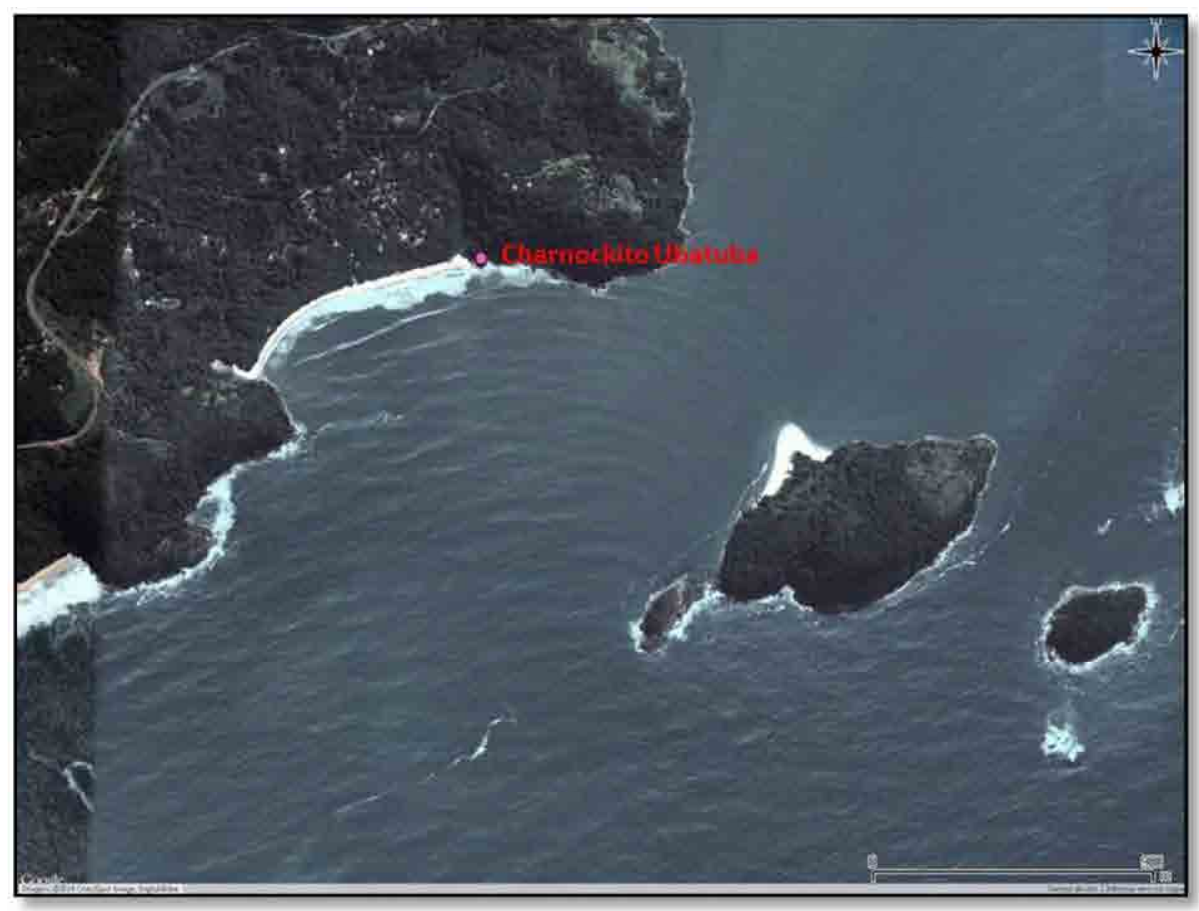

Figura 5.1.1.1 - Mapa de localização do geossítio Charnockito Ubatuba. Fonte: Google ${ }^{\circledR}$ in Qgis.

Justificativa do valor científico:

Este geossítio tem interesses ígneo, metamórfico e tectônico e representa principalmente os eventos da fase de aglutinação do Supercontinente durante o Ciclo Brasiliano II (HASUI, 2010) ou Estágio Colisional II entre 590 - $560 \mathrm{Ma}$ (HEILBRON et al., 2004).

Durante o Brasiliano II o fechamento do Oceano Adamastor e a colisão entre o cráton São Francisco e as extremidades SSW da Placa do Congo Ocidental e os terrenos situados a leste (Terreno Serra do Mar, incluindo o Arco magmático Rio Nego) estruturou o Orógeno Ribeira. Os eventos magmáticos, durante este período gerou suítes granitóides, leucogranitos, granitos porfiríticos, hornblenda-biotita granitos e charnockitos encontradas no Terreno Serra do Mar. As deformações e o magmatismo associados a este evento colisional são representados no Terreno Serra do Mar por dobras apertadas a isoclinais, xistosidade e lineação de estiramento (HASUI, 2010; HEILBRON et al., 2004). 
Elementos principais de interesse:

O charnockito de Ubatuba, como apresentado no capítulo 4, foi descrito por Neumann (1993) como uma rocha de coloração escura verde cor de garrafa, com variações de tons acinzentados e acastanhados, maciça e homogênea, equigranular a porfirítica, de granulometria média a grossa e pouco foliada (Figura 5.1.1.2a/b/c). Na região de Ubatuba, foram reconhecidos seis corpos lenticulares de charnockito. O maior deles tem aproximadamente em $250 \mathrm{~km}^{2}, 50 \mathrm{~km}$ na extensão WSW-ENE, e em média $5 \mathrm{~km}$ de largura e é sobre ele que se localiza o município de Ubatuba. A origem das rochas charnockíticas datadas em $\sim 565 \mathrm{Ma}$ por U-Pb (zircão) ID-TIMS de zircão, (AZEVEDO SOBRINHO, 2011) está relacionada provavelmente com o magmatismo tardi-orogênico no final do Proterozoico.

No geossítio o principal litotipo observado é o charnockito Ubatuba. A rocha apresenta-se bem foliada, com direção N80 mergulhando para $75 \mathrm{NE}$, bastante intemperizada com a cor rosada, apenas em algumas porções é possível ver a coloração típica do Charnockito Ubatuba, verde cor de garrafa.

$\mathrm{Na}$ laje que se encontra na altura da praia há presença de um dique de aproximadamente 0,5 metros de largura e 40 metros de extensão. Este dique foi formado por intrusões submétricas de granito róseo com enclaves de charnockito e orientação N30 (Figura 5.1.1.3).

Na mesma laje há também um dique básico, com orientação típica regional $\mathrm{NE}-\mathrm{SW}$ e aproximadamente $20 \mathrm{~cm}$ de largura (Figura 5.1.1.4). A origem do dique está relacionada com processos associados à fragmentação do Gondwana no Cretáceo Inferior (132 Ma) que culminaram na colocação do enxame de diques da Serra do Mar.

Além da importância da rocha, no local também se observam diferentes feições estruturais que ilustram estágios de colisão, como dobras intrafoliais, que são mais bem visualizadas na região de contato entre o dique granítico e o charnockito, e juntas de resfriamento (Figura 5.1.1.5a/b).

Outros tipos de interesse: Didático (nível universitário).

Uso potencial: Científico, turístico e didático (Figura 5.1.1.6).

Vulnerabilidade: Natural (baixa). 

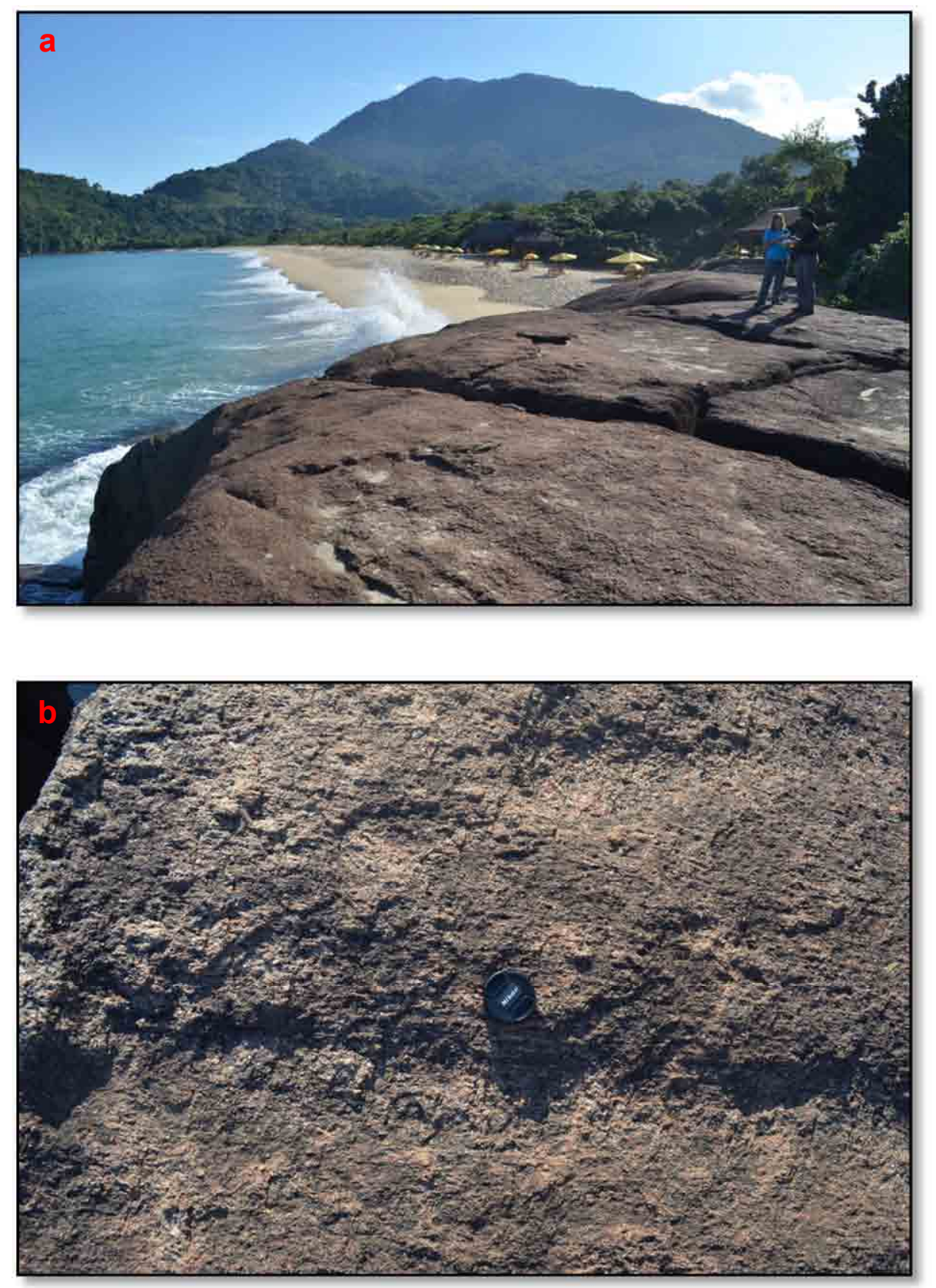

Figura 5.1.1.2 - a) Vista do geossítio Charnockito Ubatuba, situado na Praia do Prumirim; b) no afloramento nota-se que a rocha apresenta cor rosada a acastanhada com porções esverdeadas, maciça e homogênea, equigranular, de granulação de matriz média a grossa. (Fotos: Maria da Glória Motta Garcia). 


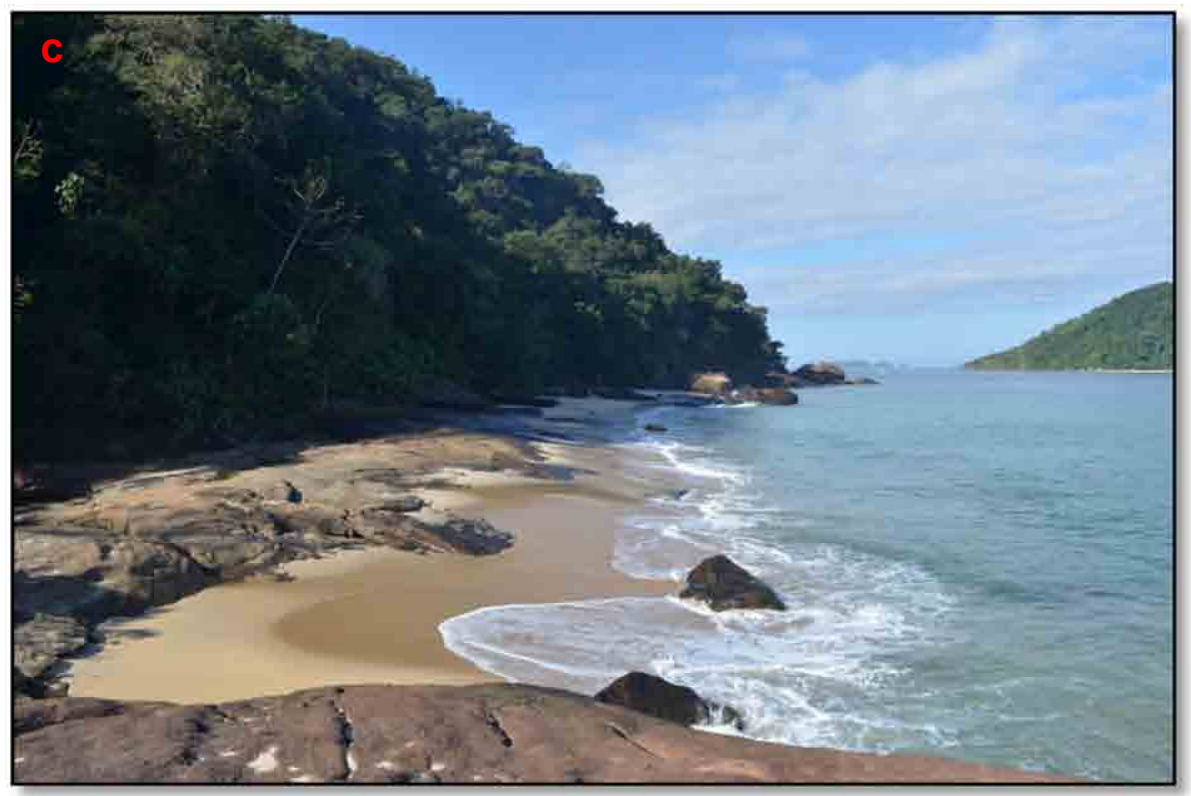

Figura 5.1.1.2 - c) Vista da laje na altura da praia que se estende por cerca da 100m. (Foto: Maria da Glória Motta Garcia).

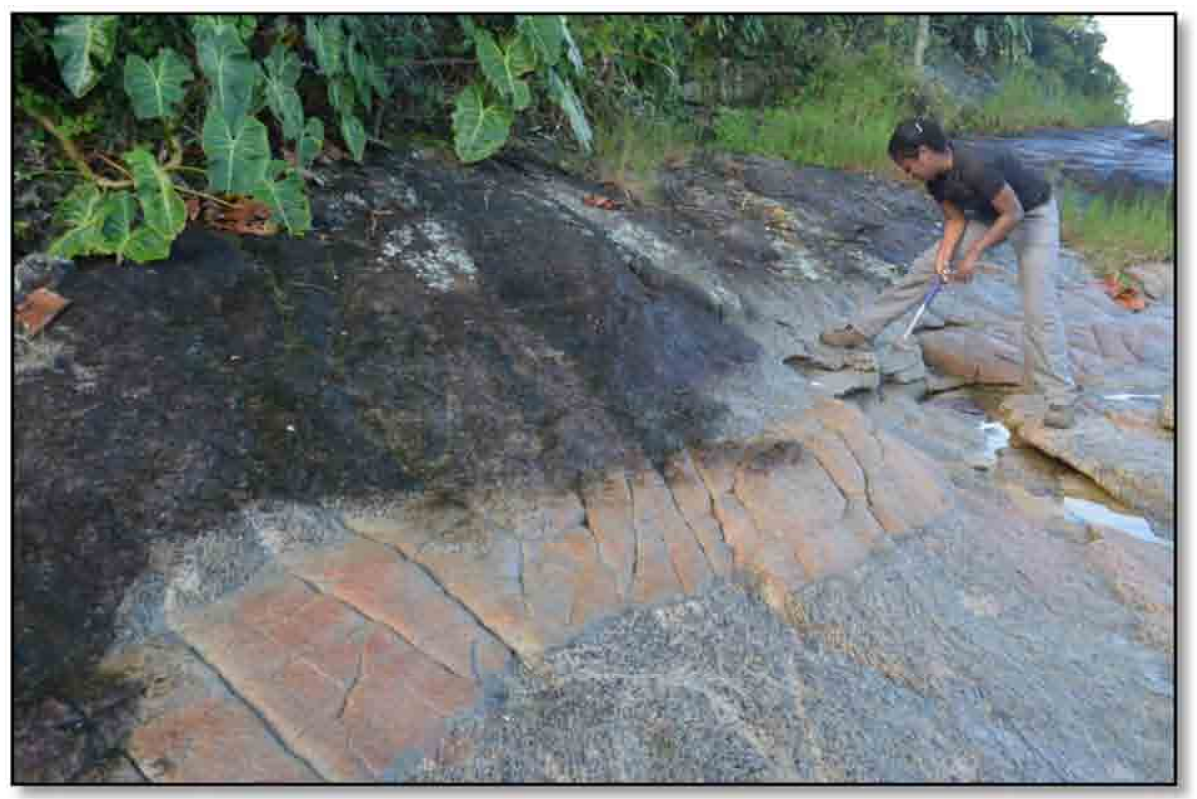

Figura 5.1.1.3 - Dique de granito fino e coloração rósea, que ocorre com orientação N30. Neste dique são encontrados enclaves de charnockito. (Foto: Maria da Glória Motta Garcia). 


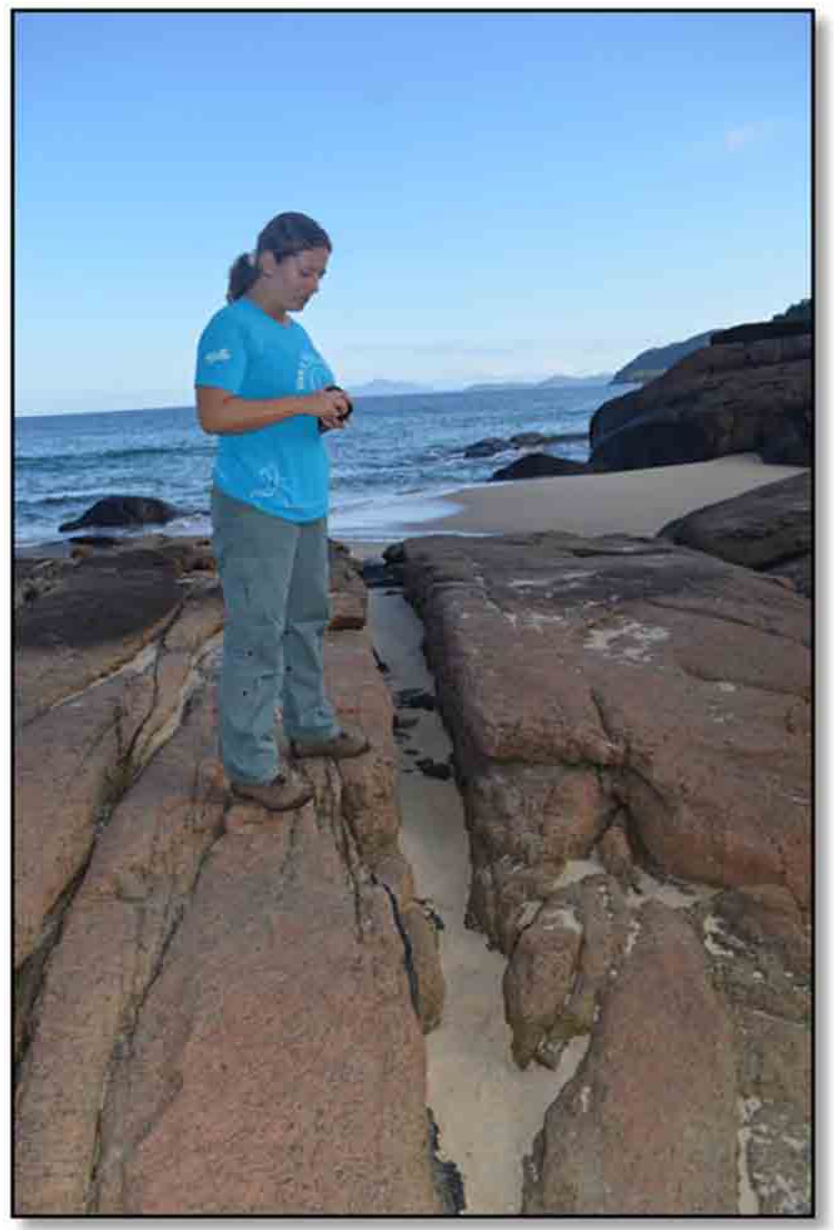

Figura 5.1.1.4 - Dique básico com orientação NE-SW (Foto: Maria da Glória Motta Garcia).

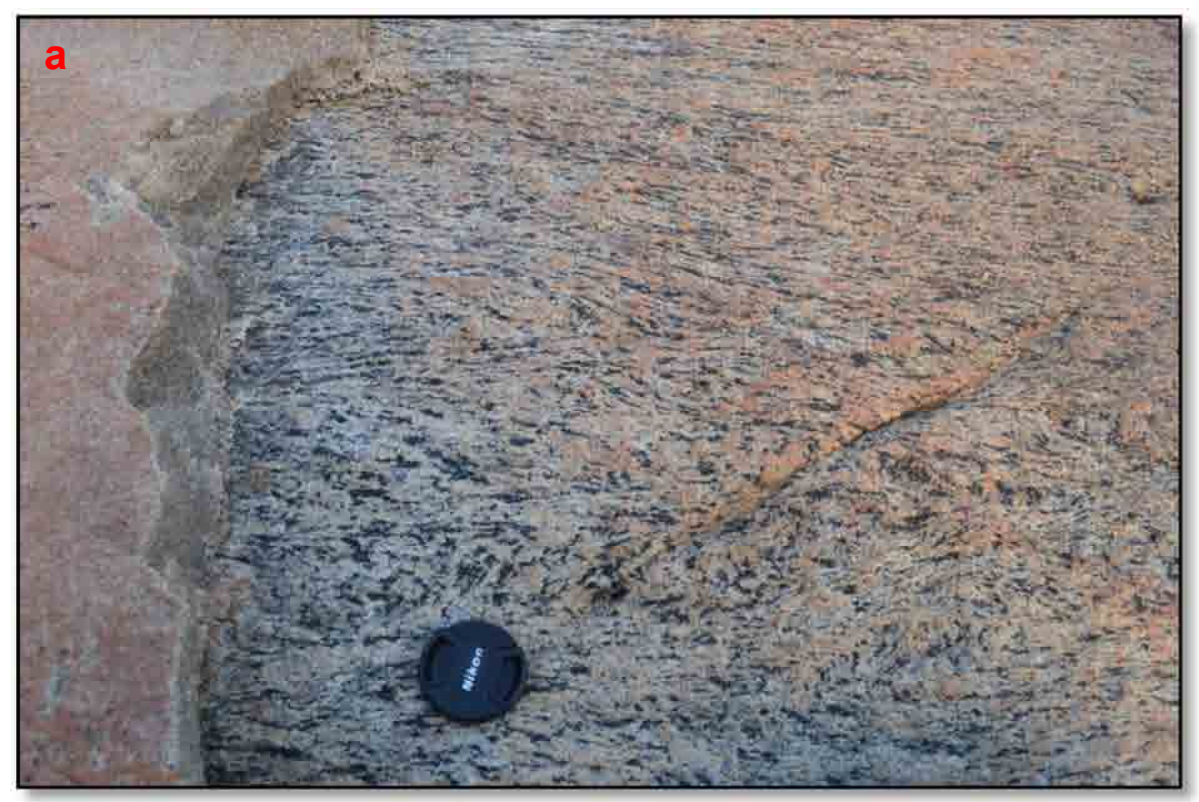

Figura 5.1.1.5 - a) Contato entre o dique granítico com o charnockito. Neste local observase que foliação da rocha é interrompida pelo dique. (Foto: Maria da Glória Motta Garcia). 


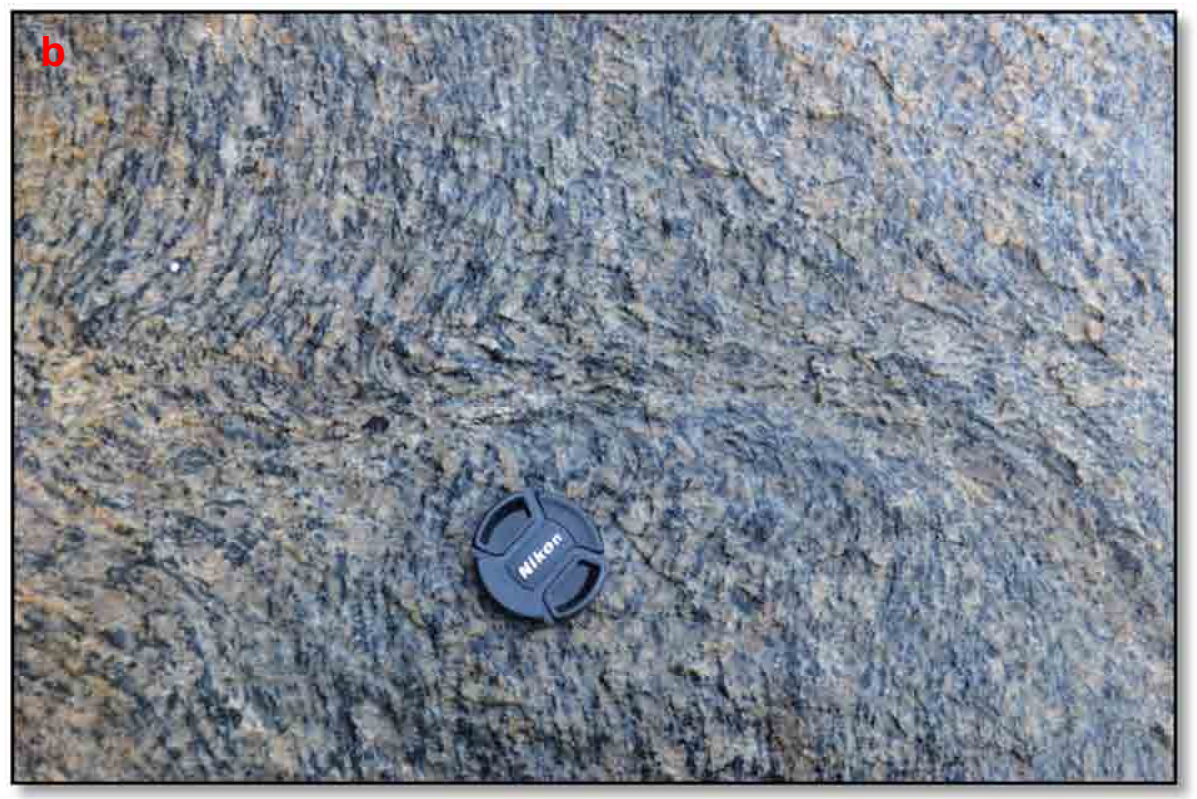

Figura 5.1.1.5 - b) Nesta foto observa-se em detalhe a foliação do charnockito, que em alguns locais encontra-se deformada (dobrada). (Foto: Maria da Glória Motta Garcia).

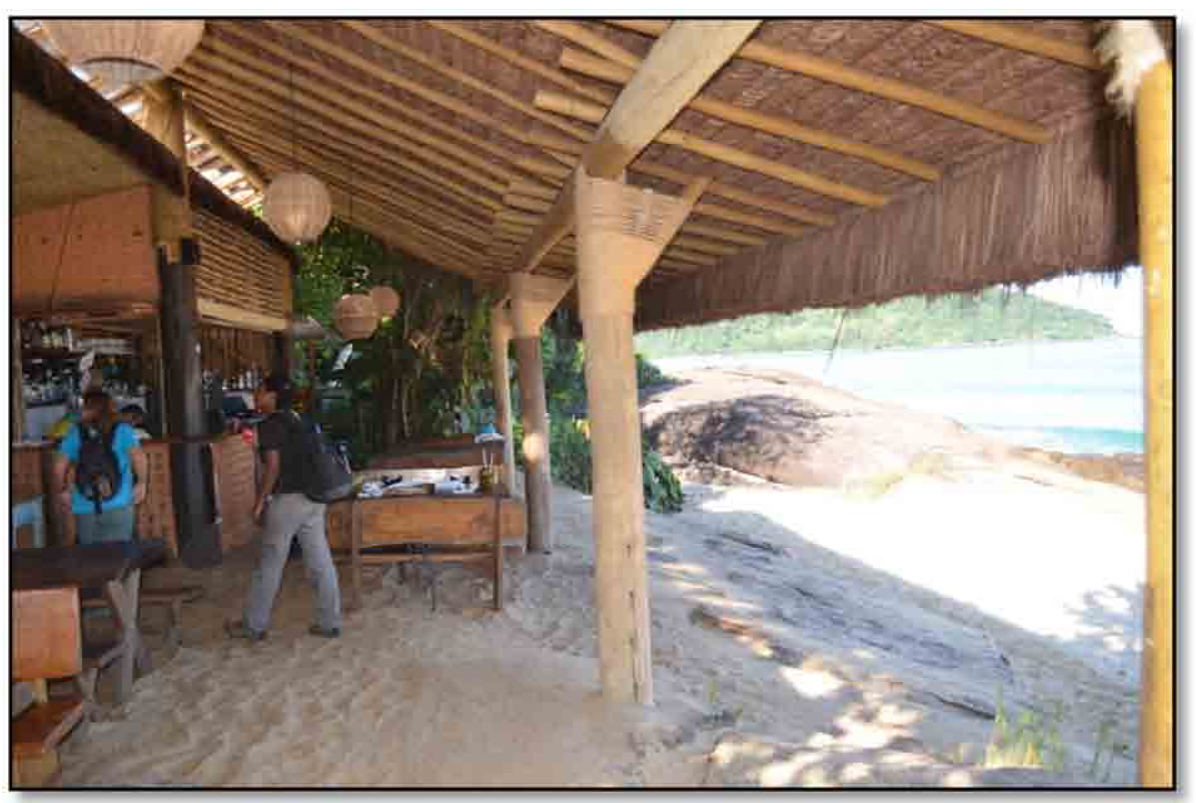

Figura 5.1.1.6 - O geossítio tem grande interesse turístico, pois no local também há um quiosque construído sobre o afloramento com materiais locais e a culinária baseia-se em ingredientes típicos da região, de origem caiçara. (Foto: Maria da Glória Motta Garcia). 
5.1.2. Geossítio da Praia do Cedro do Sul

Localização (UTM): A) 0482669/ 7396769, B) 0482793/ 7396748 (Figura 5.1.2.1)

Tipo: Área

Acesso: O acesso a Praia do Cedro do Sul é feito pelo percurso de uma trilha de nível difícil, conhecida como Trilha das Sete Praias, partindo do canto esquerdo da praia da Lagoinha a $24 \mathrm{~km}$ do centro de Ubatuba, ao Sul. O percurso tem duração de aproximadamente 5 horas, passando pelas praias do Oeste (prainha do Peres), Peres, Bonete (Bonetinho), Grande do Bonete e Deserta até a chegada ao Cedro. A trilha termina na praia da Fortaleza.

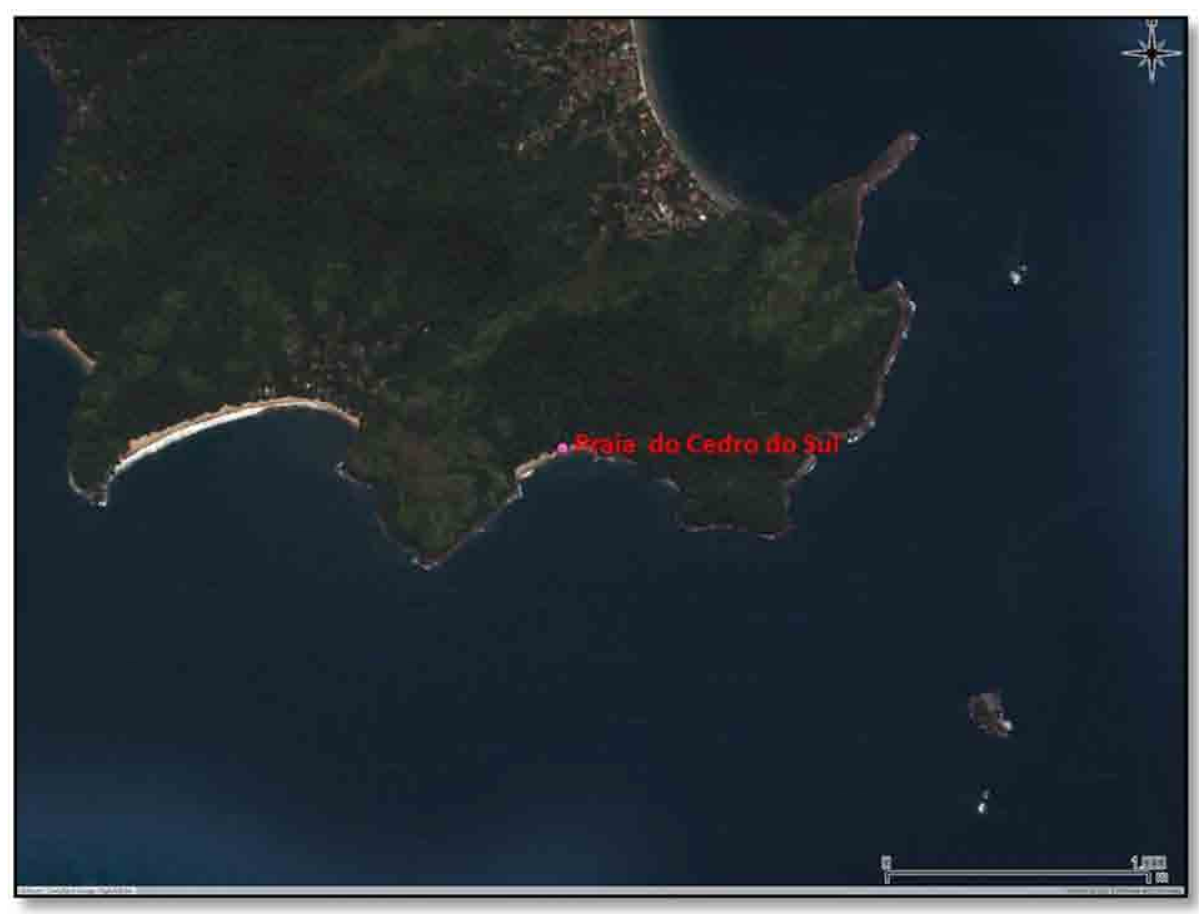

Figura 5.1.2.1 - Mapa de Localização do geossítio Praia do Cedro do Sul. Fonte: Google ${ }^{\circledR}$ in Qgis.

Dimensão: o geossítio é constituído por duas áreas: A) costão direito da praia, que tem cerca de $50 \mathrm{~m}$ de extensão e B) o costão esquerdo da praia com cerca de $50 \mathrm{~m}$ e grades blocos de rocha que começam na praia (Figura 5.1.2.2).

Unidade no mapa da CPRM (2006): NP3ay2Cub - Charnockito Ubatuba. 
Principais litotipos observadas no geossítio: A) Charnockito Ubatuba e mangeritos B) leucogranito.

Justificativa do valor científico:

As feições encontradas no geossítio registram eventos ígneos, metamórficos e tectônicos que ocorreram durante o Ciclo Brasiliano II (HASUI, 2010) ou Estágio Colisional II entre 590 - $560 \mathrm{Ma}$ (HEILBRON et. al., 2004), como abordado em 5.1.1.

Este estágio, durante a fase de aglutinação do Supercontinente, é marcado por intenso evento tectono-metamórfico que resultou na estruturação do Orógeno Ribeira. Os eventos magmáticos, durante este período gerou assembleias graníticas e charnockitos que são observados localmente (HASUI, 2010; HEILBRON et. al., 2004). As rochas charnockíticas foram submetidas à reidratação e retrometamorfismo fraco durante o soerguimento crustal em zonas de falhas e foram transformadas em descharnockitos. (MACLUF \& SCHORSCHER, 2001 ${ }^{12}$ ).

Elementos principais de interesse:

A primeira área do geossítio $(A)$ corresponde ao costão direito da praia, formado pelo charnockito Ubatuba e mangeritos. Pires $\left(2011^{13}\right)$ apresenta um mapeamento geológico e estrutural da porção SW das rochas charnockíticas em Ubatuba, entre a região da praia da Lagoinha a praia das Toninhas. O autor agrupa como "mangeritos" os charnockitos e mangeritos, separando-os pela quantidade de quartzo: charnockitos entre $20 \%$ e $60 \%$ e nos mangeritos menos que $20 \%$, de acordo com o diagrama QAP. Essas rochas afloram na região mapeada entre a praia da Lagoinha e praia Vermelha no sul na direção NW-SE, em uma faixa estreita e, entre a praia Dura e praia Domingas Dias na direção NE-SW, em uma faixa de 2 $\mathrm{km}$.

No afloramento, as rochas deste grupo correspondem a charnockitos bem foliados, de atitude N140 mergulhando para $40 \mathrm{SW}$. Esta foliação resulta da orientação dos minerais e concentração de minerais máficos. A textura da rocha

\footnotetext{
${ }^{12}$ MACLUF, S. \& SCHORSCHER, J.H.D. Petrogênese das rochas charnockíticas e aplitos intrusivos do complexo charnockítico de Ubatuba, SP. Trabalho apresentado no $7^{\circ}$ Simpósio de Geologia do Sudeste. Minas Gerais, Nov. 1995. 46p.

${ }_{13}$ PIRES, A.S. Mapeamento geológico e estrutural da porção SW do charnockito de Ubatuba, SP. 2011. 40 p. e anexos. Monografia de trabalho de formatura, Instituto de Geociências, Universidade de São Paulo. 2011. 
varia de equigranular a porfirítica e a granulação de média a grossa. No local observa-se a presença de um dique granítico com enclaves da rocha encaixante. Próximo à borda do dique, observa-se mudança da granulação de média para grossa e, uma mudança na cor, que passa de esverdeada para rosada. Esta mudança é descrita por Neumann (1993) como efeito de "descharnockitização" gerando os "descharnockitos", segundo Macluf \& Schorscher (2001) (Figura 5.1.2.3a/b).

O processo de "descharnockitização" consiste na transformação dos charnockitos em "descharnockitos" de coloração róseo-esbranquiçada por hidratação e retrometamorfismo fraco "durante o soerguimento crustal em zonas de falha e contanto com as rochas encaixantes regionais, e ainda, pela intrusão de diques aplíticos" (MACLUF \& SCHORSCHER, 2001: 46).

Em todo o afloramento se observam fraturas com orientação N30. Estas fraturas registram os processos extensionais que ocorrem durante a fase de fragmentação do Supercontinente antes da abertura do Oceano Atlântico.

Estes eventos foram seguidos por intenso magmatismo, que ocorreram como derrames basálticos corpos toleíticos e alcalinos que compõem o enxame de Diques da Serra do Mar (Capítulo 4). Localmente, estes eventos são ilustrados pela presença de "restos" de um dique lamprófiro (MELO, 2008), orientado N40 (Figura 5.1.2.4a/b).

Finalmente na área $(A)$, observam-se algumas feições de alteração nas rochas, como a esfoliação esferoidal, formando blocos bem arredondados, de tamanhos submétricos (Figura 5.1.2.4c/d).

$A$ área $(B)$ corresponde ao costão esquerdo e blocos métricos a submétricos que começam na praia, a rocha aflorante é um leucogranito. Esta rocha apresenta grande quantidade de quartzo e feldspato, índice de cor baixo, granulação média e foliação incipiente. Neste local são encontrados blocos regulares que são formados na direção preferencial de uma família de fraturas. Estas fraturas formam um ângulo de aproximadamente $90^{\circ}$ (Figura 5.1.2.5a/b/c). Os dados de Macluf \& Schorscher (2001) e Neumann $\left(1994^{14}\right)$, sugerem que esta assembleia granítica tenha sido gerada durante o processo de descharnockitização, pela transformação de ortoclásio

\footnotetext{
${ }^{14}$ NEUMANN, R. Charnockitos de Ubatuba, leste do estado de São Paulo: petrografia, geobarometria e considerações tectônicas. Trabalho apresentado no $38^{\circ}$ Congresso Brasileiro de Geologia. Balneário Camboriú, SC. 1994. 46 p.
} 
em pertítico em microclínio, hiperstênio em hornblenda, biotita e clorita com plagioclásio. Esta transformação teria sido facilitada por uma zona de deformação mais intensa, porém mantendo as características estruturais das rochas encaixantes regionais.

Outros tipos de interesse: Didático (nível universitário).

Uso potencial: Científico, turístico e didático.

Vulnerabilidade: Natural (baixa).

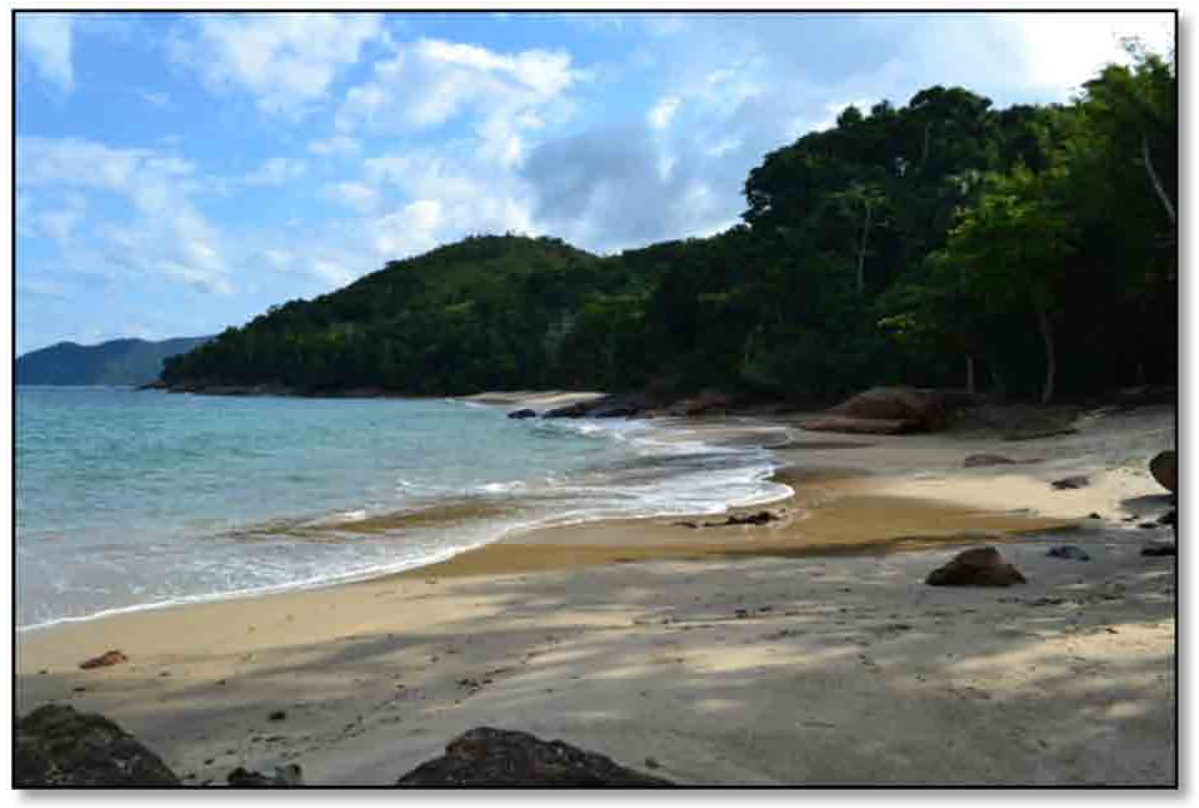

Figura 5.1.2.2 - Vista da área B para A do geossítio Praia do cedro do Sul. 


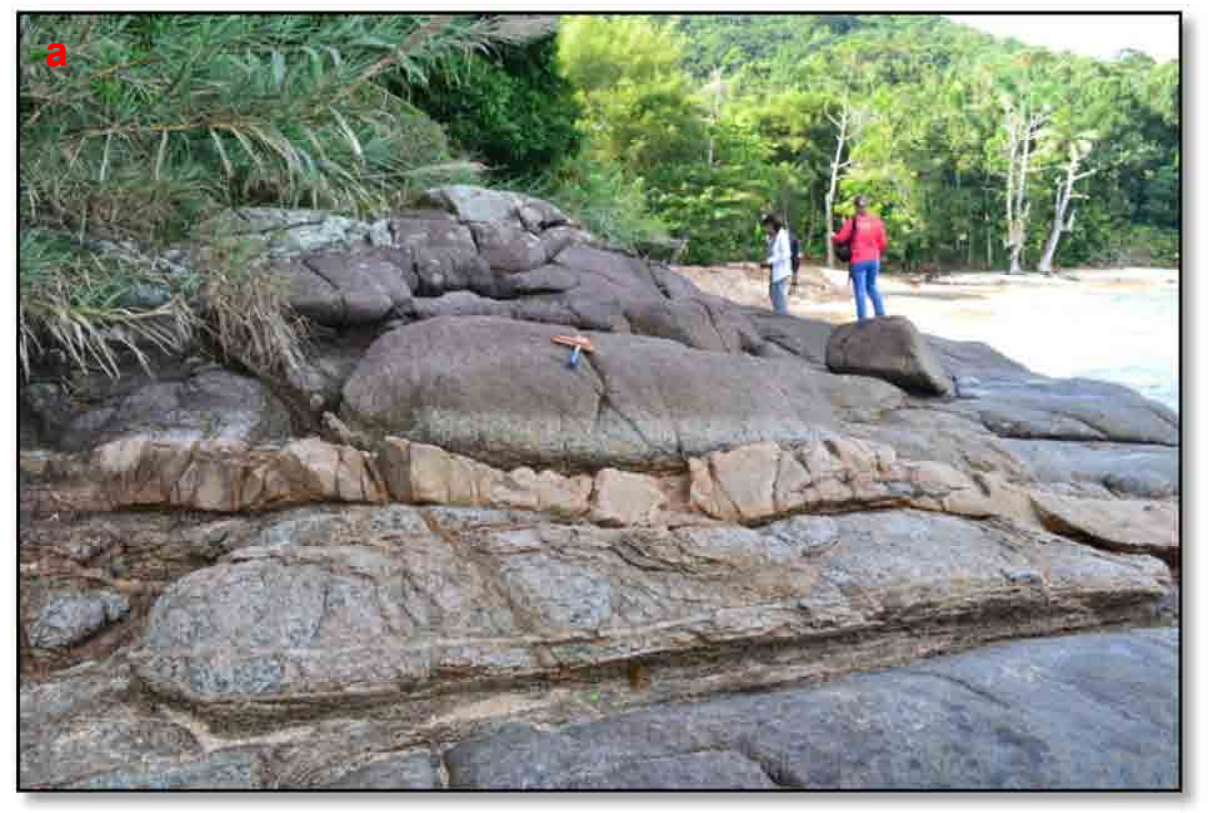

Figura 5.1.2.3 - a) Vista do afloramento na área A do geossítio, observa-se a intrusão de um dique granítico. (Foto: Maria da Glória Motta Garcia)

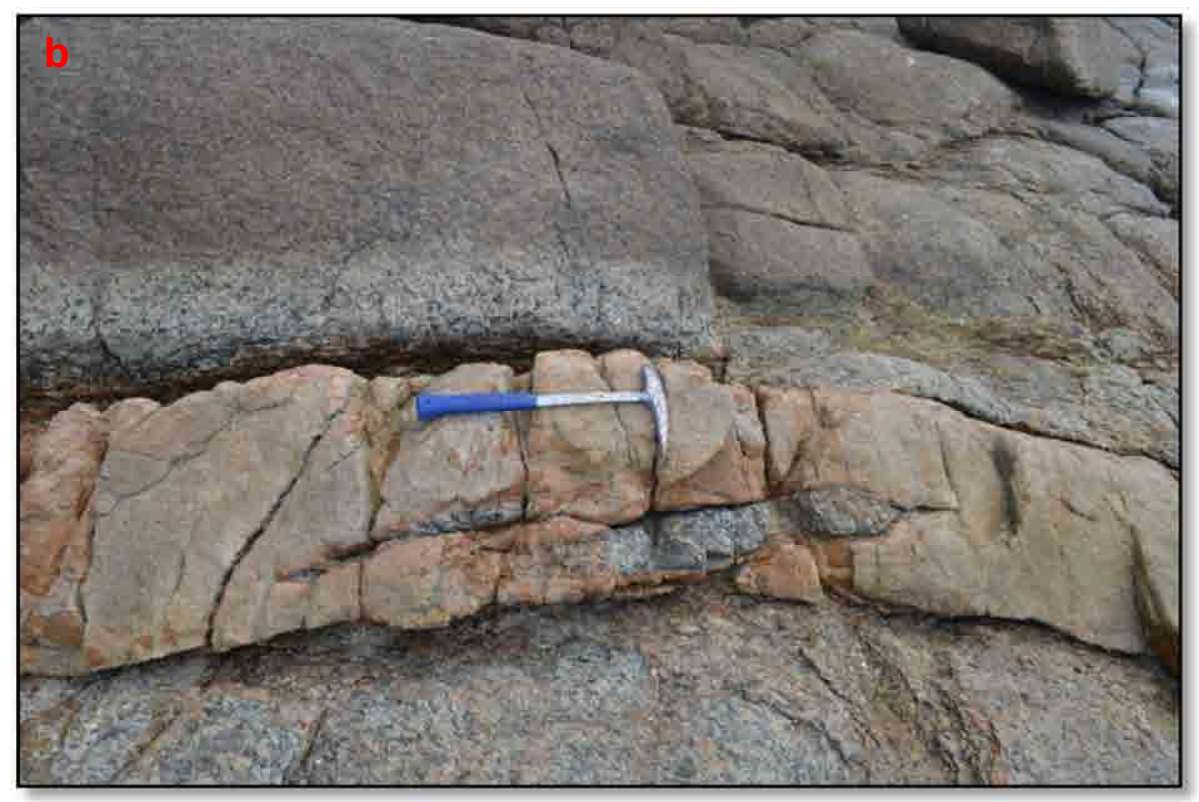

Figura 5.1.2.3 - b) Detalhe do dique granítico com enclave da rocha encaixante, na borda observa-se uma na coloração da rocha, que passa de esverdeada para rosada característico do processo de "descharnockitização". (Foto: Maria da Glória Motta Garcia) 

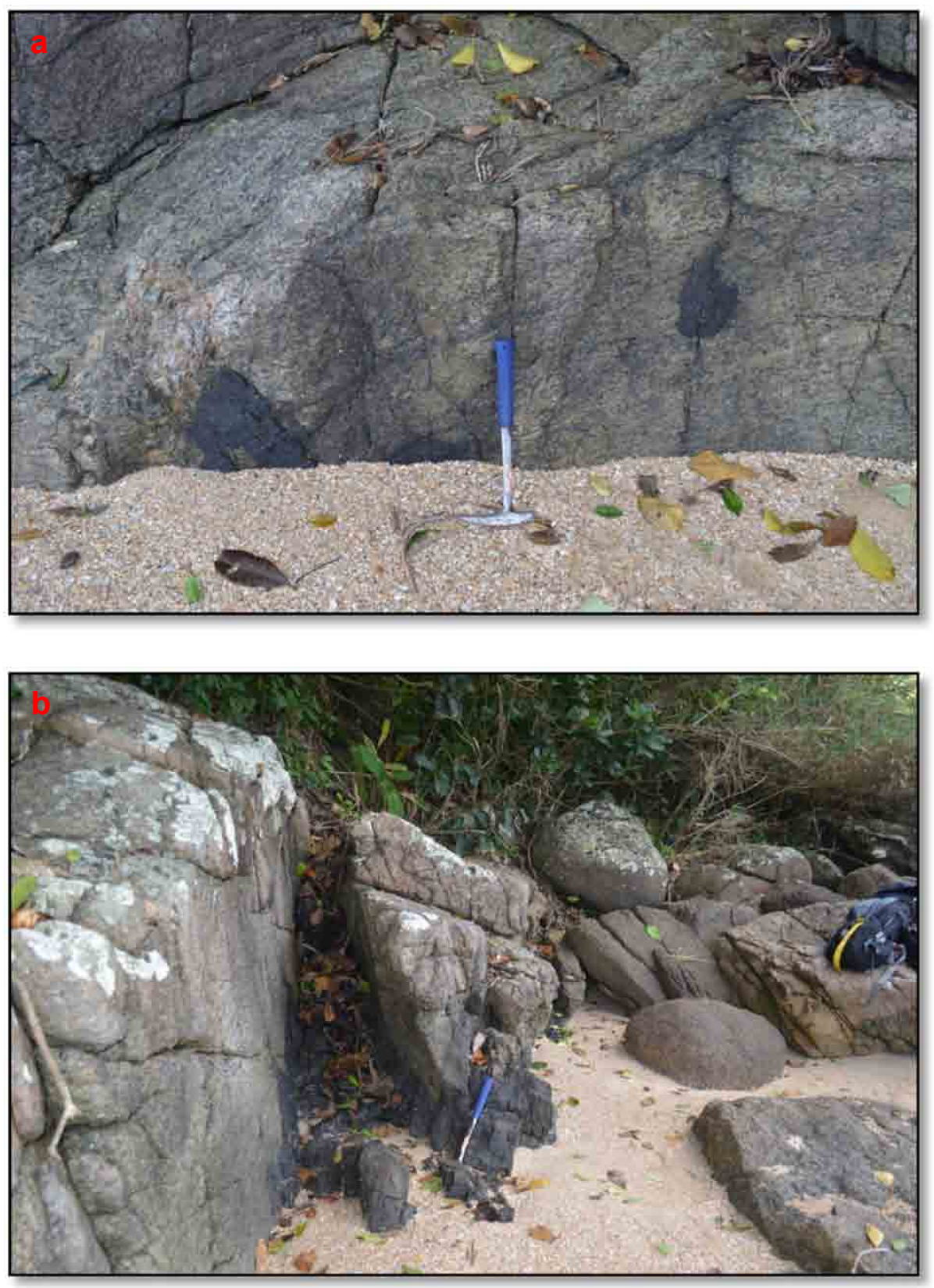

Figura 5.1.2.4 - a) Nesta foto observa-se o charnockito Ubatuba pouco alterado, com coloração esverdeada. Nota-se ainda a foliação da rocha que ocorre com orientação N140 mergulhando para SW e a presença de restos de um dique máfico. Em b) observa-se "restos" de dique lamprófiro concordante as fraturas N30. (Fotos: Maria da Glória Motta Garcia). 

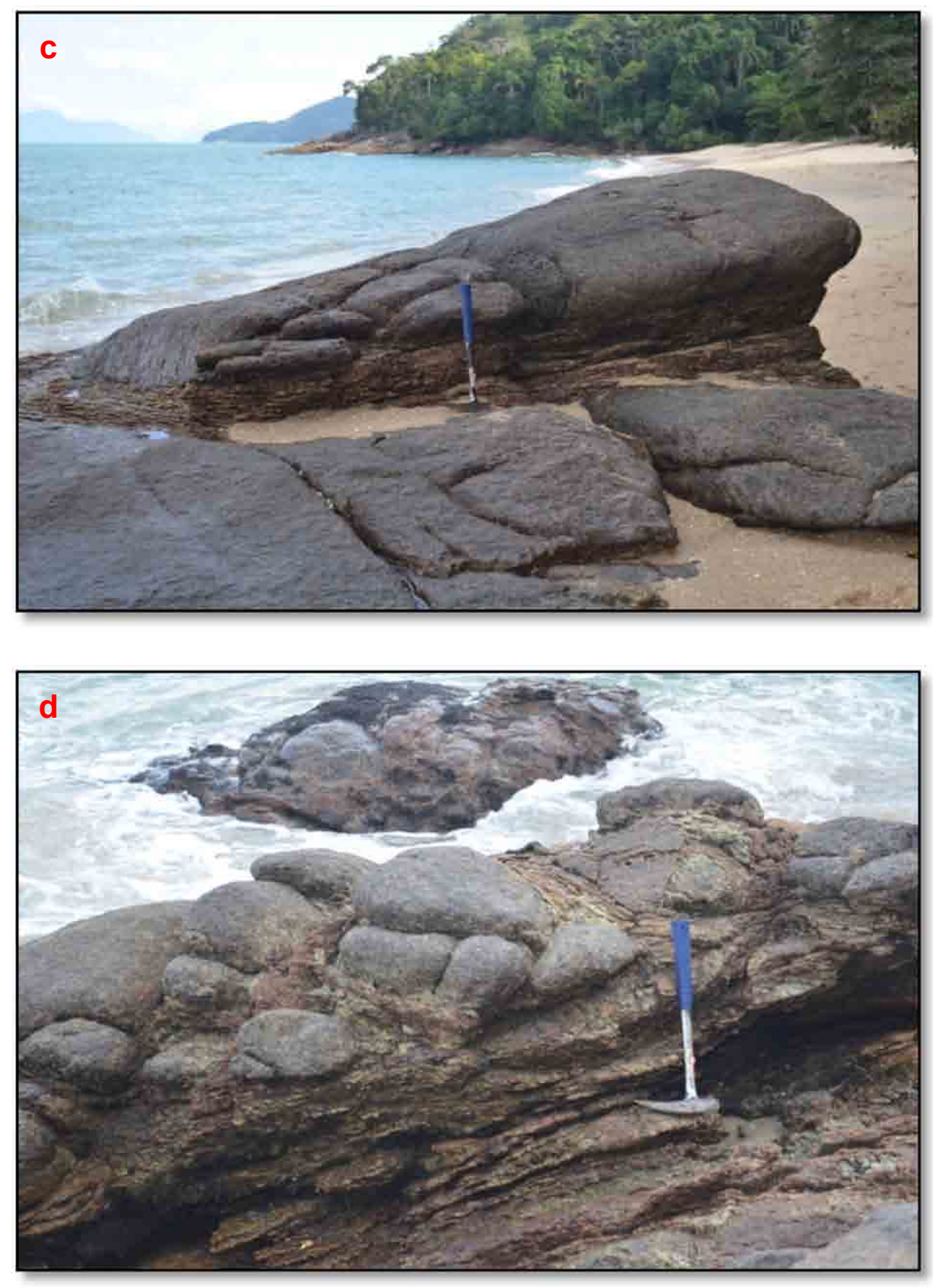

Figura 5.1.2.4 - c) e d) Na parte A do geossítio são encontradas algumas feições que também agregam valor ao geossítios. Como exemplo, uma das formas de alteração observadas nas rochas, a esfoliação esferoidal, em que os agentes do intemperismo atuam na desagregação da rocha formando camadas que são destacadas do vértice para o centro, resultando na formação de blocos bem arredondados. (Fotos: Maria da Glória Motta Garcia). 

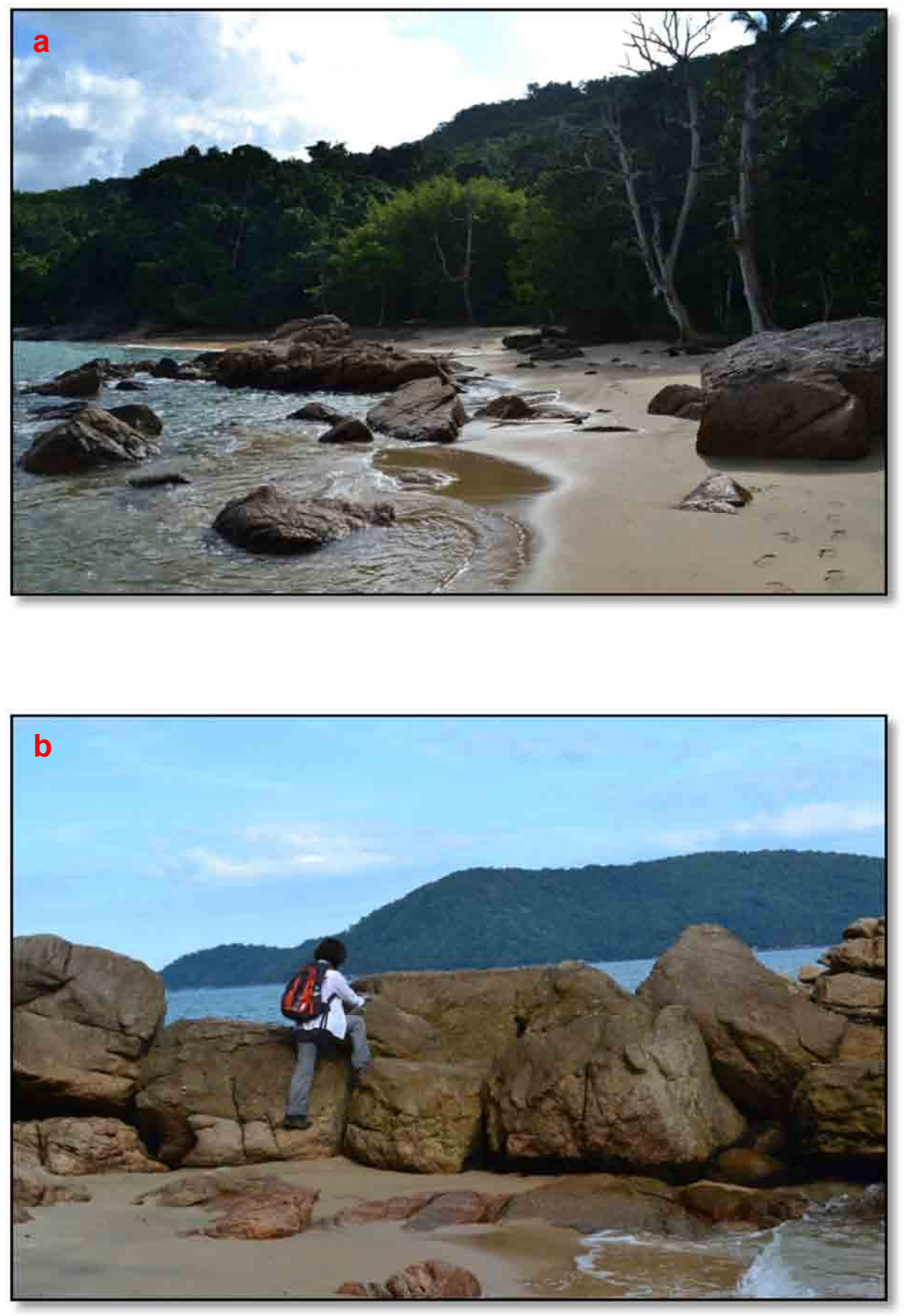

Figura 5.1.2.5 - a) Vista para área B do geossítio Praia do Cedro do Sul; b) Vista a partir da parte (B) do geossítio. Observam-se grandes blocos de coloração róseo-esbranquiçado ao longo da praia. (Fotos: Maria da Glória Motta Garcia e Érick Mota). 


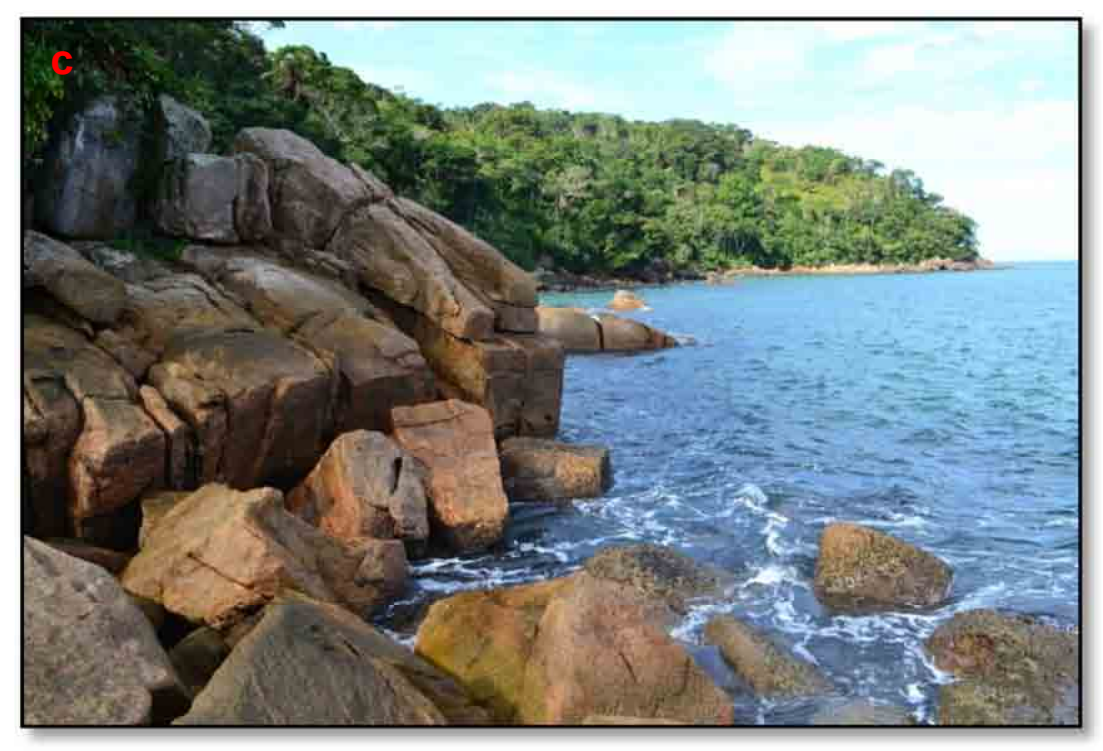

Figura 5.1.2.5 - c) Vista a partir da parte (B) do geossítio. Observam-se grandes blocos de coloração róseo-esbranquiçado ao longo do costão rochoso. Estes blocos, de tamanho variados, são formados nos planos preferencias de uma família de fratura que formam um ângulo de aproximadamente $90^{\circ}$. (Foto: Érick Mota).

5.1.3. Geossítio Pedra do Sino de Ubatuba

Localização (UTM): 0489506/ 7401660 (Figura 5.1.3.1).

Tipo: Ponto

Acesso: O geossítio está localizado na Praia da Santa Rita, cerca de $10 \mathrm{~km}$ ao sul do centro de Ubatuba. O acesso à praia se dá por servidão pública seguindo pela Rodovia Rio - Santos (BR101), sentido Caraguatatuba até a saída da Praia do Perequê-Mirim. Chega-se a praia por uma via secundária passando pela portaria de um condomínio particular. 


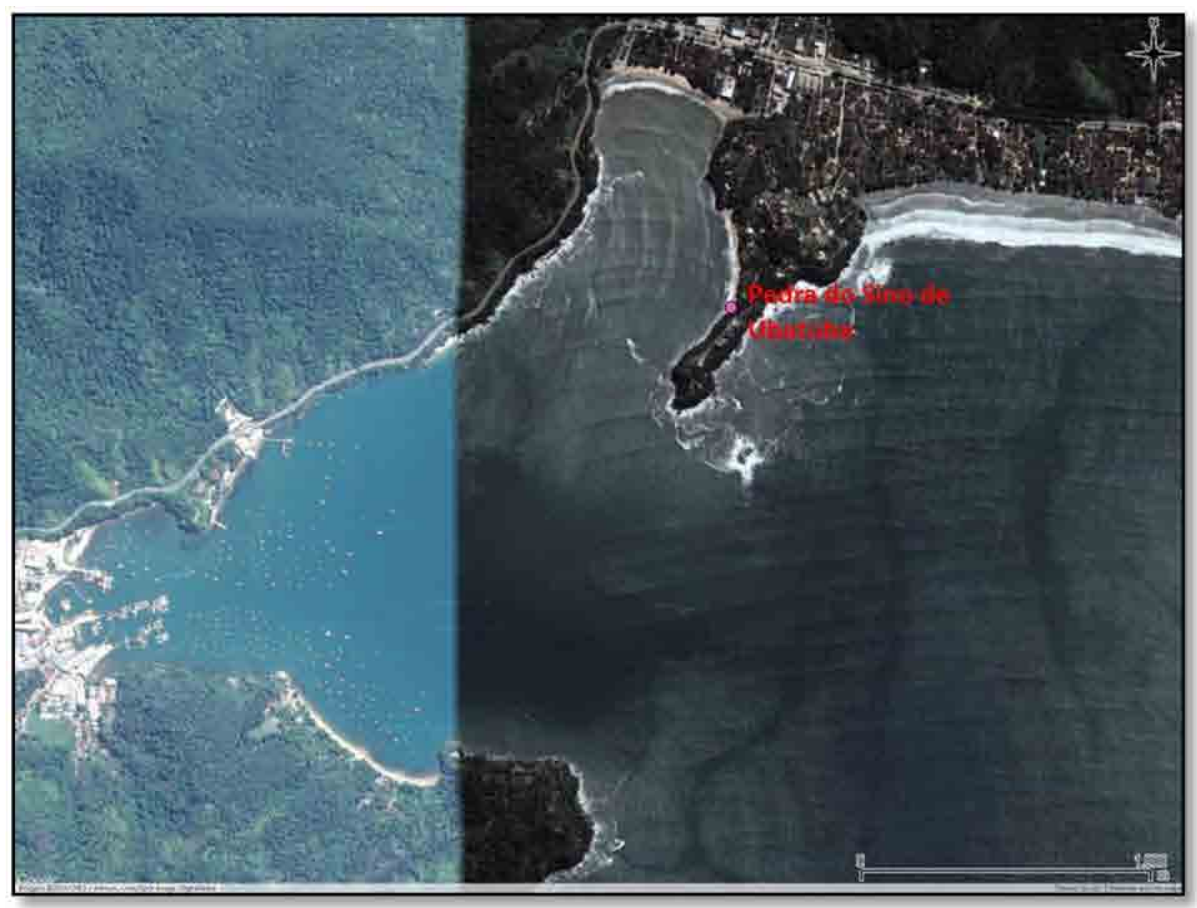

Figura 5.1.3.1 - Mapa de Localização do geossítio Pedra do Sino de Ubatuba, Praia da Santa Rita. Fonte: Google $®$ in Qgis.

Dimensão: trata-se de um costão rochoso de aproximadamente 150 metros na Praia da Santa Rita.

Unidade no mapa da CPRM (2006): NP3ay2Cub - Charnockito Ubatuba.

Principais litotipos observadas no geossítio: Charnockito Ubatuba

Justificativa do valor científico:

Este geossítio tem interesse ígneo, metamórfico e tectônico, pois é um local de observação do charnockito de Ubatuba e ilustra o processo de descharnockitização. Porém o local foi inserido no inventário pelo seu caráter turístico, devido ao som de sino emitido pelas rochas.

Elementos principais de interesse:

Este geossítio tem interesse ígneo, tectônico e metamórfico ilustrado pelo processo de "descharnockitização" - transformação dos charnockitos em "descharnockitos" por hidratação e retrometamorfismo fraco durante o soerguimento 
crustal - apresentado em 5.1.2. Além disso, esta praia é conhecida turisticamente pela "Pedra do Sino de Ubatuba".

O afloramento é formado pelo charnockito Ubatuba bem foliado na direção N40 mergulhando para 43SE. A granulação da rocha varia de fina a grossa e a cor da rocha passa de esverdeada para esbranquiçada e rosada (Figura 5.1.3.2a/b).

No costão esquerdo da Praia da Santa Rita são encontrados blocos médios e grandes com tamanhos que variam de 0,5 a 2 metros e se estendem por cerca de 150 metros até a Praia da Enseada (Figura 5.1.3.3). Estes blocos encontram-se bem arredondados e ocorrem com resultado da atuação do intemperismo físico e químico. Nestas formas de intemperismo os blocos inicialmente apresentam-se de formas cúbicas de acordo com o conjunto de fraturas que os formou (nas direções N60 mergulhando para 78SE e N120 mergulhando para 70SW) tende ao arredondamento, na forma de esfoliação esferoidal - desagregação dos vértices dos blocos para o interior, formando camadas que são destacadas de formas concêntricas, assemelhando-se as cascas de cebolas (Figura 5.1.3.4a/b/c/d).

Ao bater com um martelo nos blocos encontrados na praia, estes soam como um sino, semelhante ao som das rochas do geossítio "Pedra do Sino de llhabela", localizada na praia da Garapocaia na Ilhabela, cuja principal litotipo encontrado é um nefelina - sienito (PROCHOROFF, 2014). Estudos sistemáticos sobre as possíveis causas do som nessas rochas não foram encontrados. Segundo Prochoroff (2014), a ocorrência desse fenômeno pode estar relacionada tanto as condições das rochas para propagação de ondas sonoras quanto disposição dos blocos encontrados no local. Contudo, neste estudo não se pode confirmar.

Outros tipos de interesse: Didático (nível universitário) e Turístico.

Uso potencial: Científico, turístico e didático.

Vulnerabilidade: Natural (baixa). 


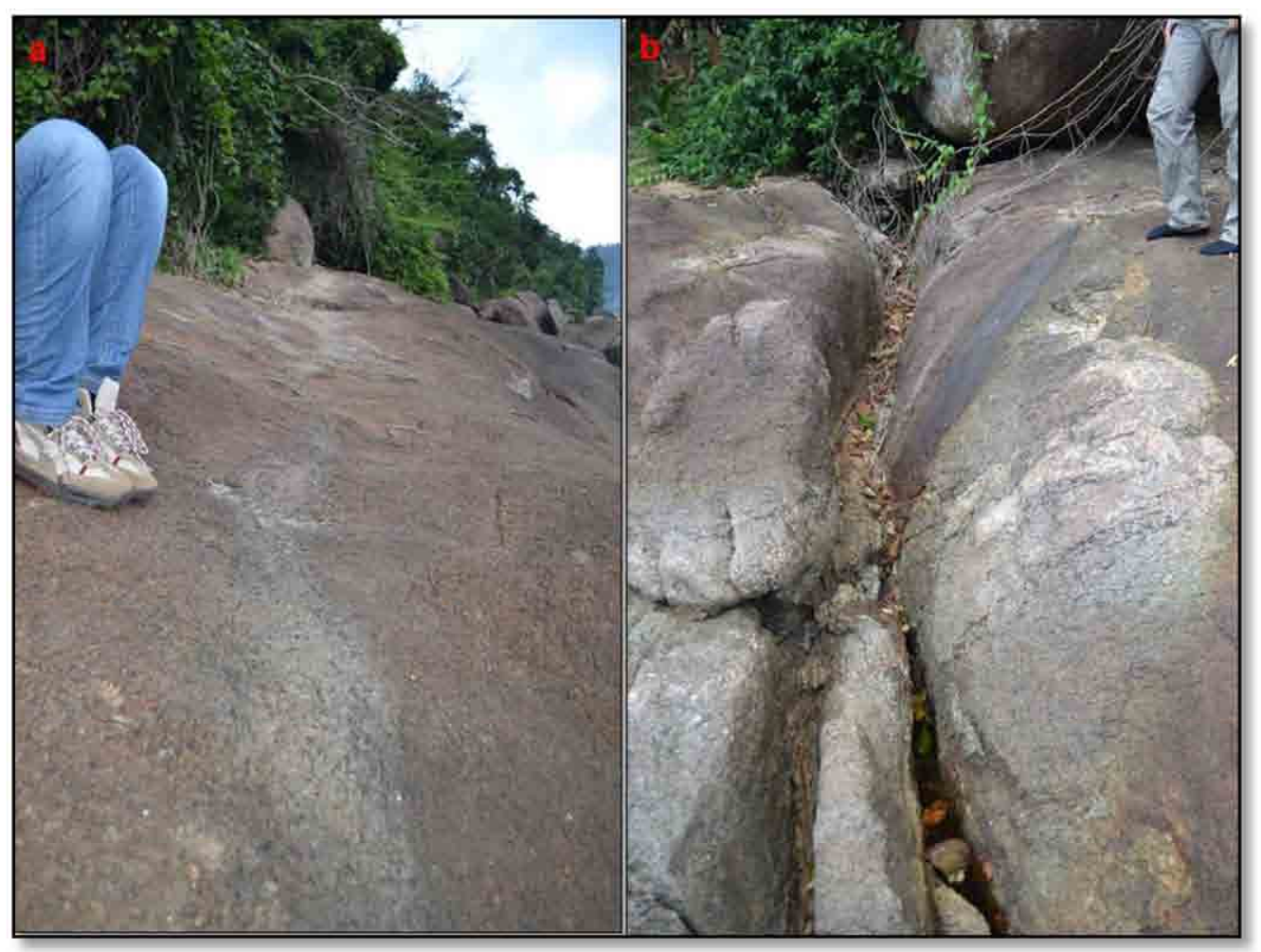

Figura 5.1.3.2 - a) Observa-se o charnockito Ubatuba bem foliado na direção N40, e granulação média. $\mathrm{Em}$ b) observa-se a mudança na cor da rocha passando de tons esverdeados a esbranquiçado e rosado. (Fotos: Maria da Glória Motta Garcia)

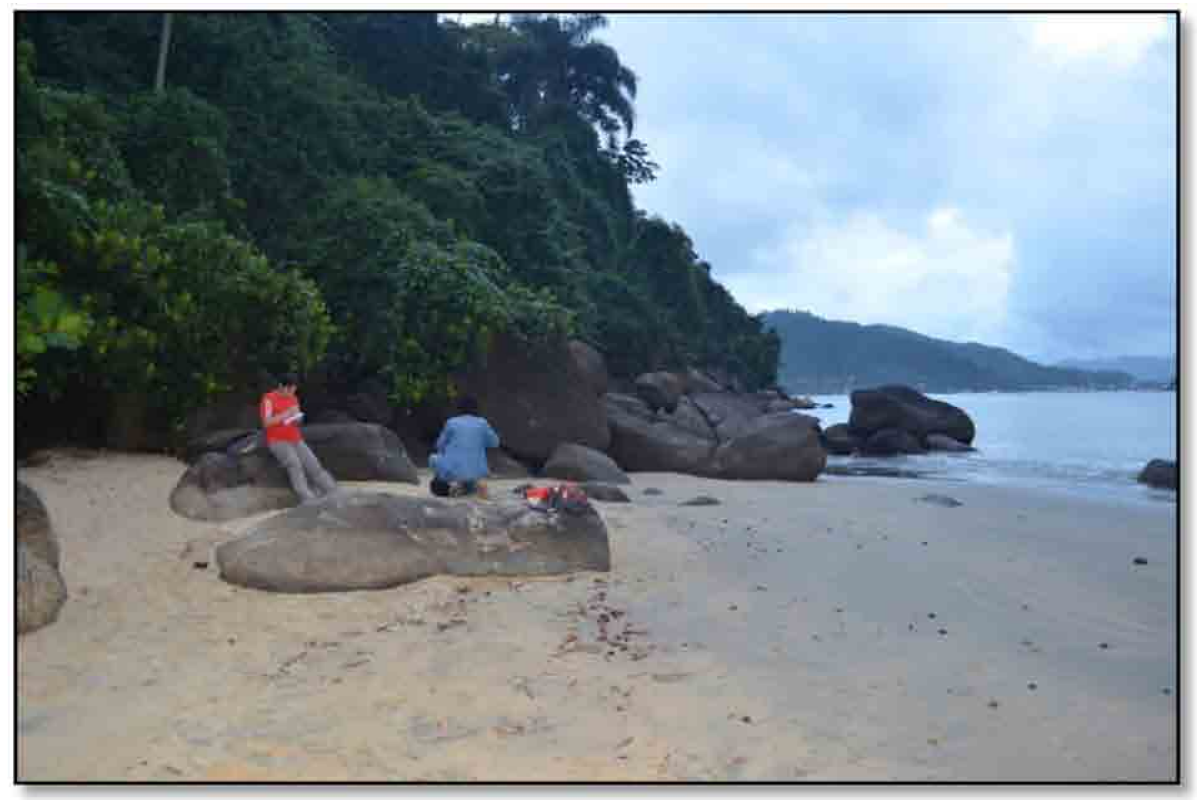

Figura 5.1.3.3 - Vista para o geossítio Pedra do Sino de Ubatuba. Os blocos disposto na praia, próximo ao afloramento, emitem o som de sino ao bater com um martelo. 


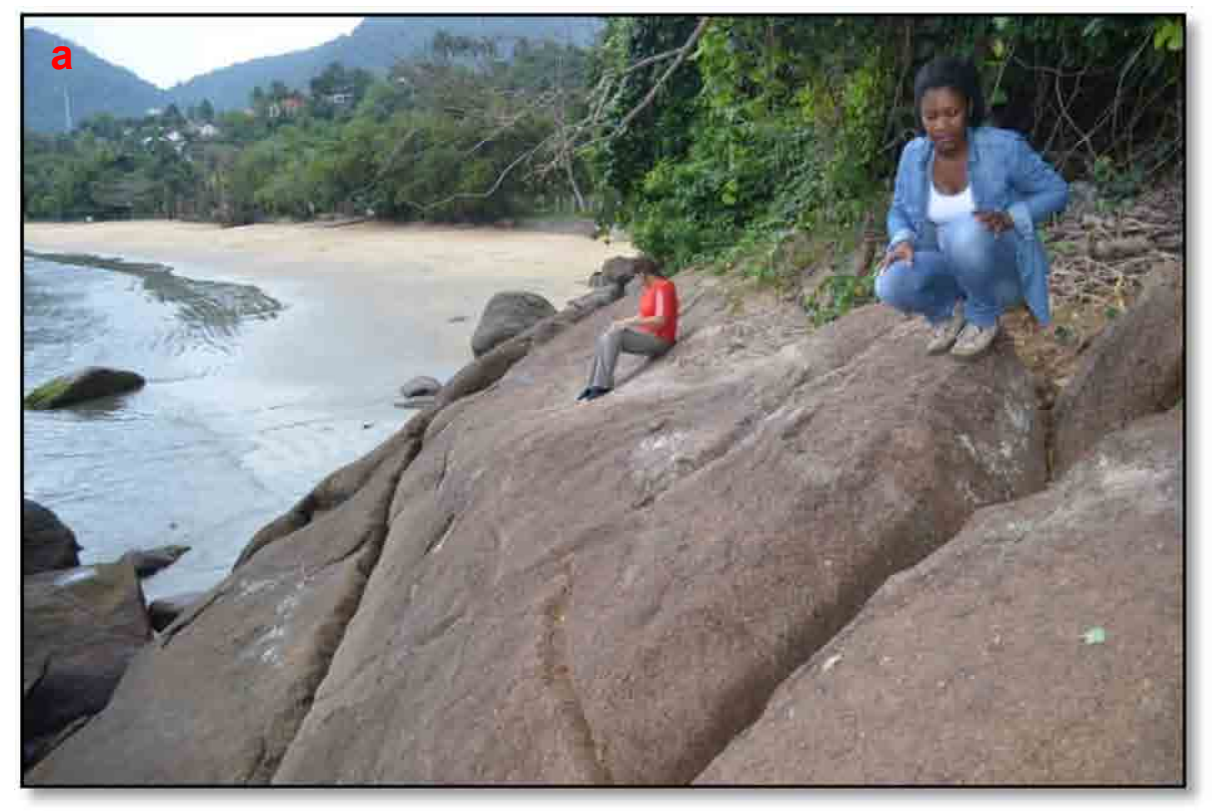

Figura 5.1.3.4 - a) Vista do afloramento para a praia da Santa Rita. Na rocha, observam-se duas famílias de fraturas localmente nas direções N60 mergulhando para SE e N120 mergulhando para SW. (Foto: Maria da Glória Motta Garcia)

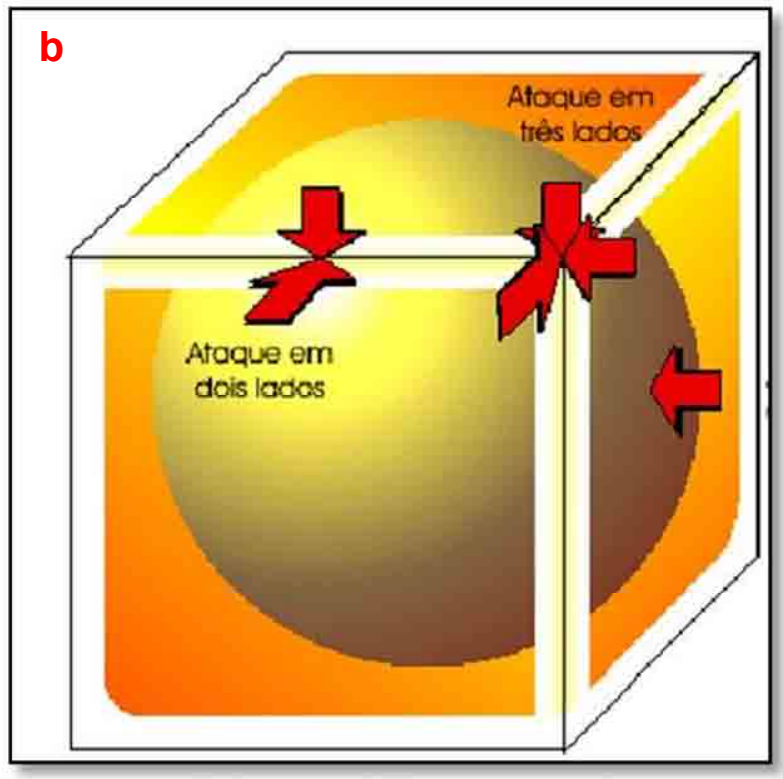

Figura 5.1.3.4 - b) No processo de formação da esfoliação esferoidal os agentes do intemperismo atuam na desagregação dos blocos rochosos a partir dos vértices em direção ao centro formando camadas que posteriormente são destacadas de modo semelhante as cascas de cebolas. Fonte: Material didático Curso Agronomia da Universidade de Brasília UnB. 

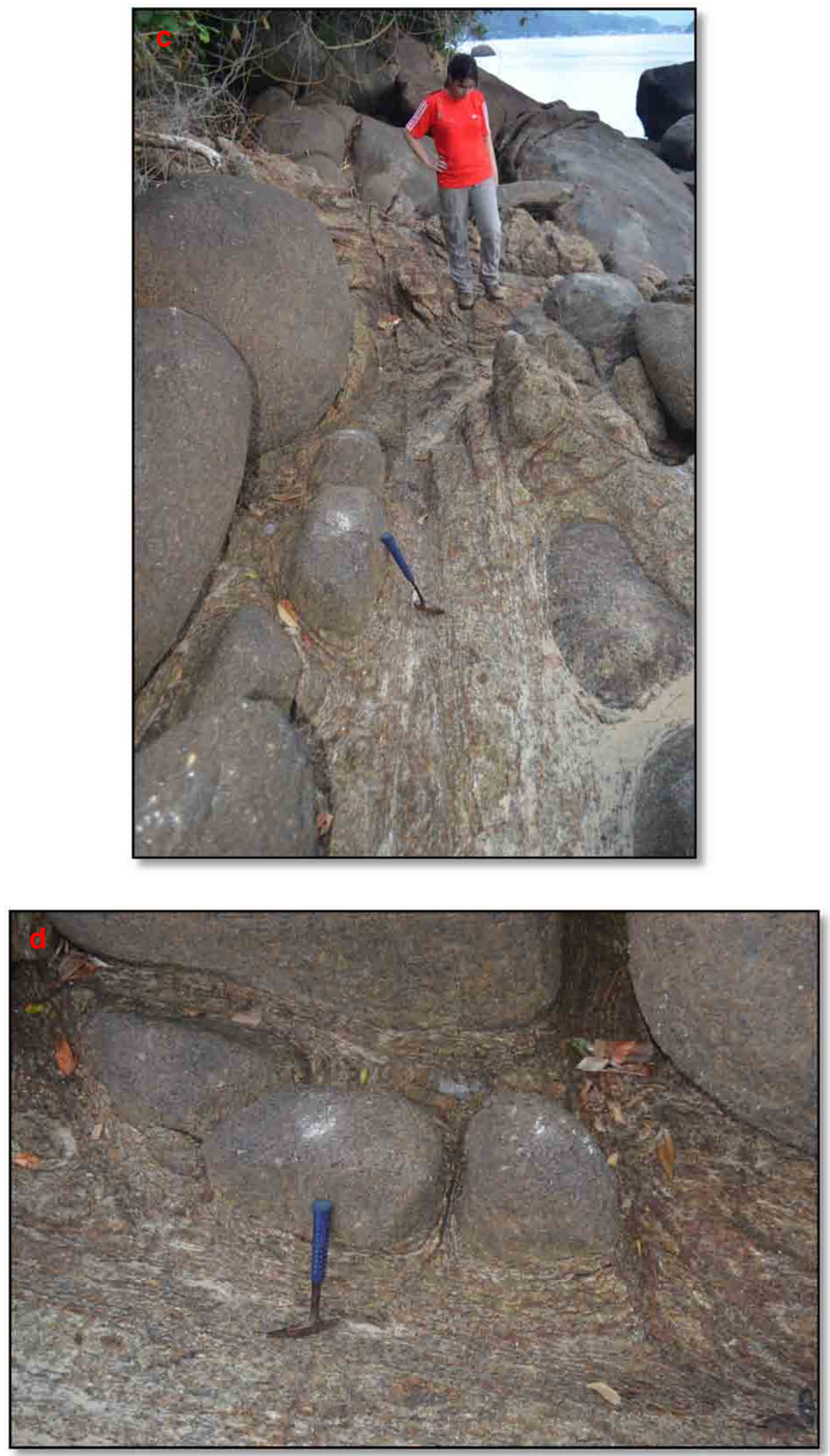

Figura 5.1.3.4 - c) e d) Blocos bem arredondados resultantes de esfoliação esferoidal que ocorre de acordo com os planos de fraqueza presentes na rocha. (Fotos: Maria da Glória Motta Garcia) 


\subsubsection{Geossítio da Praia da Ponta Aguda}

Localização (UTM): 0473131/ 7391270 (Figura 5.1.4.1).

\section{Tipo: Ponto}

Acesso: A praia da Ponta Aguda está localizada a $32 \mathrm{~km}$ do centro de Ubatuba, ao sul. O acesso à praia é feito por via secundária, uma estrada de cascalho e terra na primeira entrada para Tabatinga no Município de Caraguatatuba. Há também o percurso de uma trilha de nível médio, a "Trilha da Caçandoca" no limite entre os dois Municípios passando pelo morro da Caçandoca ou pode ser feito de barco. No local há presença de comunidades caiçaras.

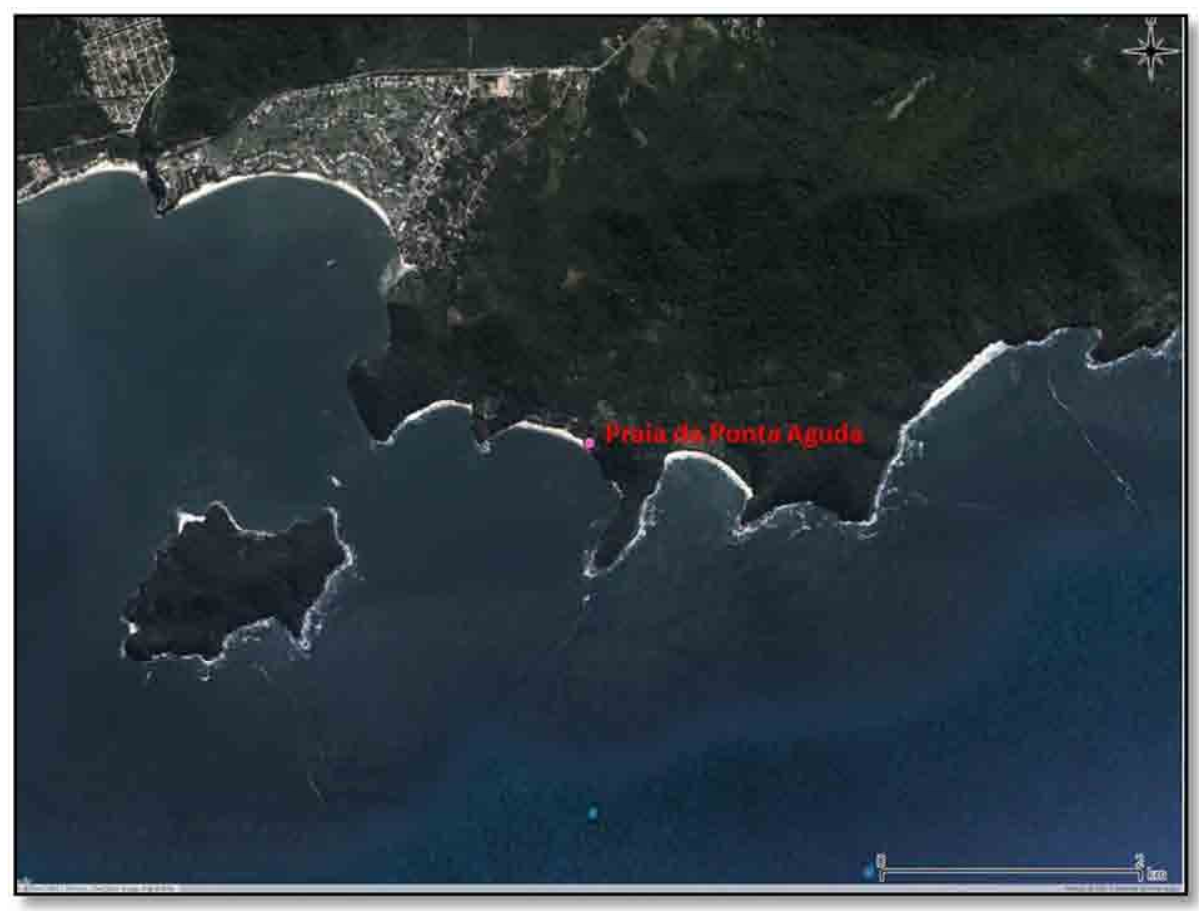

Figura 5.1.4.1 - Mapa de localização do geossítio Praia da Ponta Aguda. Fonte: Google ${ }^{\circledR}$ in Qgis.

Dimensão: trata-se do costão esquerdo da praia com cerca de 150 metros de comprimento.

Unidade no mapa da CPRM (2006): NPccgm - Hornblenda-biotita granitoide porfiróide e augen gnaisse.

Principais litotipos observadas no geossítio: gnaisse granítico bandado. 
Justificativa do valor científico:

A interpretação de dados estruturais, metamorfismo e magmatismo sugerem a ocorrência de três eventos deformacionais ao longo da história geológica dos terrenos que compõem a Faixa Ribeira: (i) durante o Neoproterozoico (595-565 Ma) (HEILBRON, 1995; MAGALHÃES, 2012), (ii) Paleozoico (540-520 Ma) (TUPINAMBÁ et. al., 2007) e (iii) evento associadas às zonas de cisalhamento dúcteis e rúpteis, (HEILBRON et. al., 1995, 2000; TROUW et. al., 2000 apud MAGALHÃES, 2012), (Capítulo 4). Este geossítio de interesse ígneo, metamórfico e tectônico ilustra os diferentes eventos que ocorreram ao longo desta história geológica.

Elementos principais de interesse:

Na Praia da Ponta Aguda, o costão esquerdo da praia é formado por um ortognaisse granítico finamente bandado em contato com rocha máfica. $\mathrm{O}$ gnaisse granítico ocorre bem foliado, com orientação N20 mergulhando para 55SE, apresenta uma textura equigranular a porfirítica, granulação que varia de média a grossa e está bastante deformado. A foliação das rochas é paralela a uma clivagem plano axial, de acordo com a foliação do gnaisse, representadas por dobras que se pode observar em porções mais félsicas da rocha (Figura 5.1.4.2a/b/c/d/e/f).

No geossítio observam-se restos de um dique de cor escura e granulação fina que corta o gnaisse, sendo interpretado como sin-plutônico. Pires (2011) apresenta em mapeamento regional, que a ocorrência destes diques, em geral, apresenta-se em falhas ou fraturas, normalmente paralelos a foliação da rocha, como ocorre localmente (Figura 5.1.4.3).

As rochas desta unidade geológica, de acordo com Passarelli $\left(2001^{15}\right)$ apud CPRM $\left(2006^{16}\right)$ foram datadas em 647-578 Ma em U-Pb. Estes dados sugerem que a deformação encontrada no geossítio ilustra os processos do primeiro evento deformacional que ocorreu durante o Neoproterozoico (595-565 Ma) e desenvolveu

\footnotetext{
${ }^{15}$ Passarelli, C.R. Caracterização estrutural e geocronológica dos domínios tectônicos da porção suloriental de estado de São Paulo. 2001. 254 p. e apêndices. Tese de Doutorado, Instituto de Geociências, Universidade de São Paulo. 2001.

${ }^{16}$ Os dados atribuídos a esta unidade geológica pela CPRM baseiam em Passarelli (2001). Contudo os dados obtidos pela autora baseiam-se principalmente em amostras de rochas graníticas provenientes da porção sul do litoral do estado de São Paulo, entre as regiões de lguape e Mongaguá.

87
} 
estruturas como dobras assimétricas, foliação principal, zonas de cisalhamento com formação de milonitos e lineação de estiramento e lineações de minerais (HEILBRON, 1995; MAGALHÃES, 2012). Localmente este evento teria gerado as estruturas como dobras assimétricas, foliação principal do gnaisse granítico. Eventos posteriores resultariam no desenvolvimento das famílias de fraturas encontradas no local (que formam um ângulo de aproximadamente $90^{\circ}$ que foram pequenos blocos em parte do afloramento), estes poderiam ter ocorrido, por exemplo, durante o último evento deformacional que provavelmente está associado ao colapso do Orógeno Ribeira (HEILBRON et. al., 1995, 2000; TROUW et. al., 2000 apud MAGALHÃES, 2012).

Outros tipos de interesse: Didático (nível universitário).

Uso potencial: Científico e didático.

Vulnerabilidade: Natural (baixa).

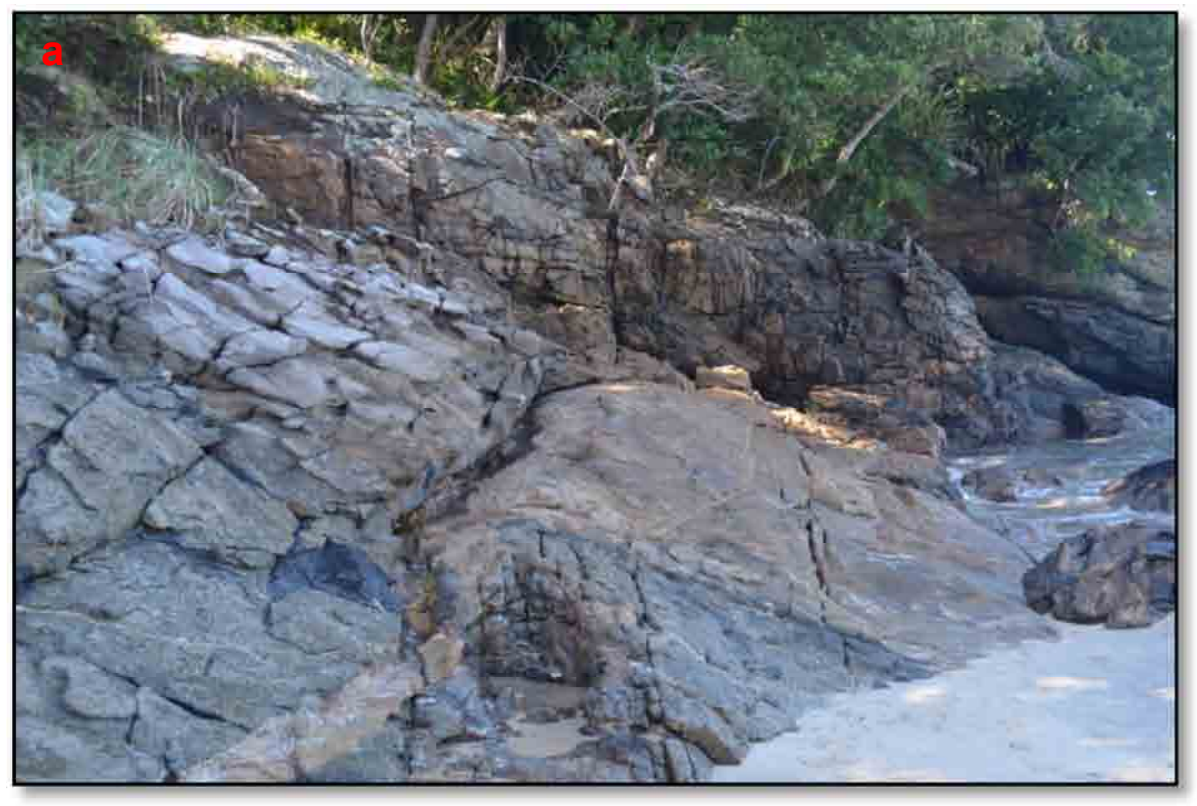

Figura 5.1.4.2 - a) Vista do afloramento, que compõe o geossítio. Observa-se o contato entre o gnaisse granítico rosado com o biotita gnaisse. Neste local, observam-se ainda diferentes estruturas apresentadas em detalhe nas fotos: b), c), d), e) e f). 

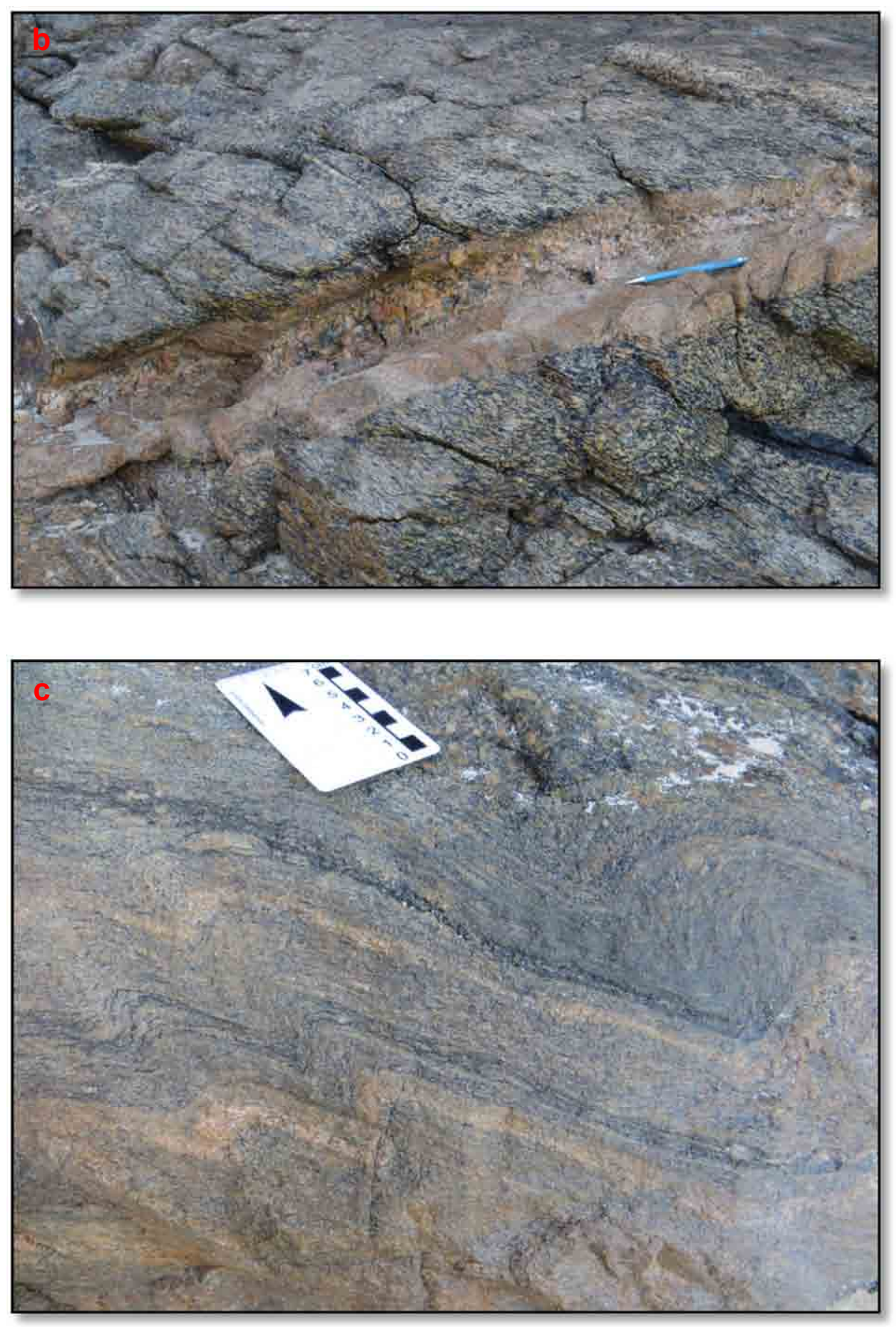

Figura 5.1.4.2 - b) Detalhe da foto (a), em que se observa um veio pegmatítico discordante a foliação da rocha. Nota-se que o gnaisse granítico ocorre em algumas porções com granulação grossa e textura equigranular, c) observa-se em detalhe o contato plástico entre o gnaisse granítico e a uma rocha máfica e a formação de um bandamento. 

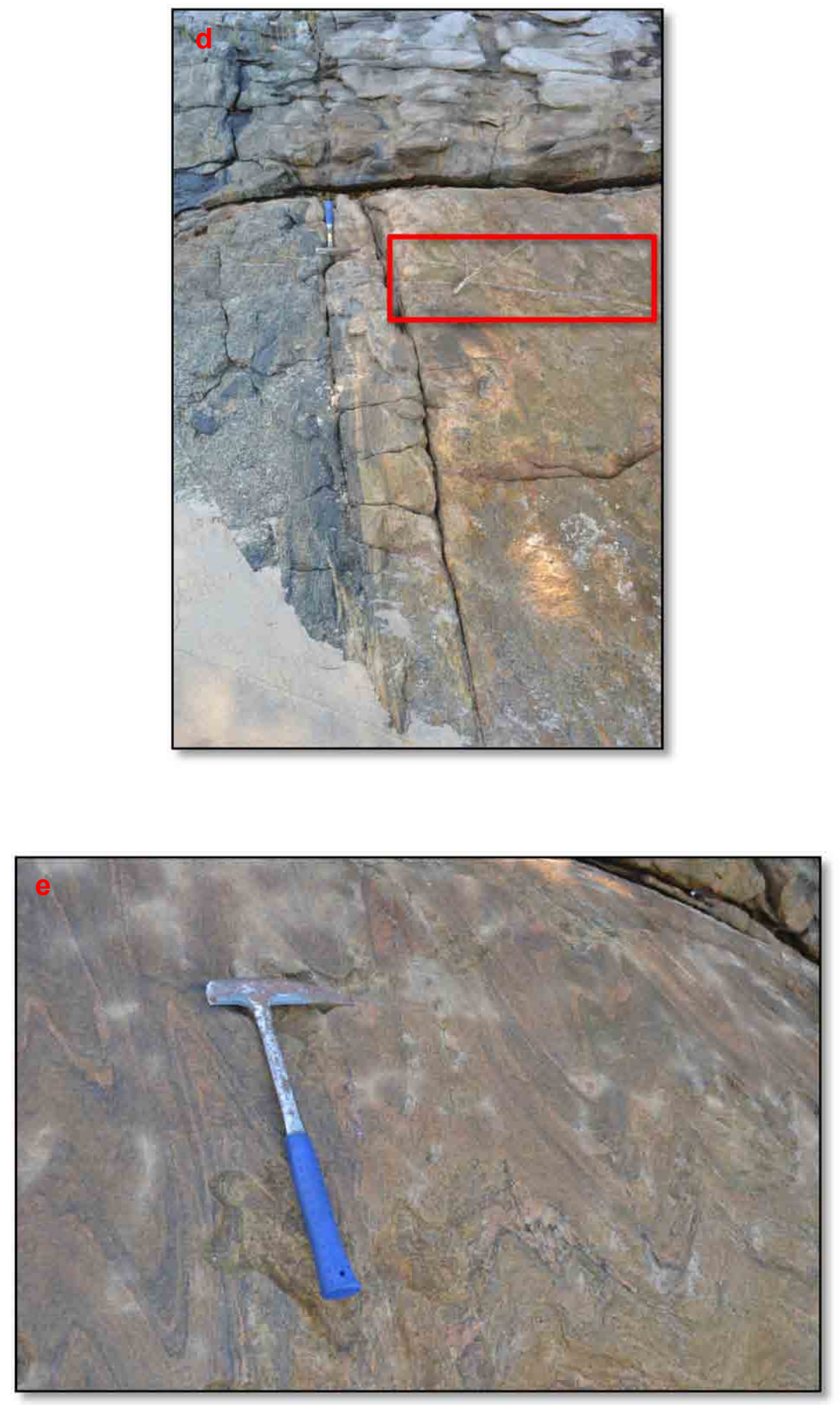

Figura 5.1.4.2 - d) Detalhe do contato entre as duas rochas: biotita gnaisse à esquerda e gnaisse granítico à direita, cortado por finos veios pegmatíticos (em destaque), e) Detalhe da foto (a) em que observam-se o dobramento das rochas, que ocorre de acordo com a foliação do gnaisse granítico. 


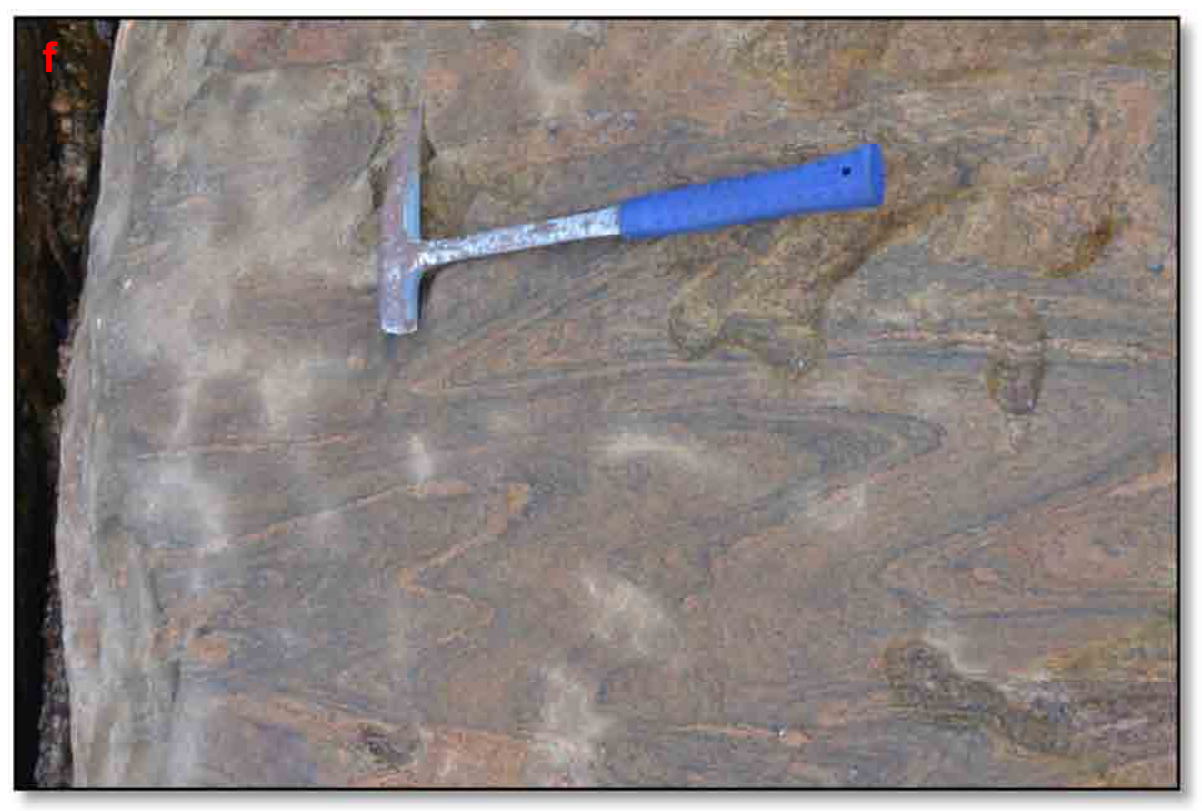

Figura 5.1.4.2 - f) Detalhe da foto (a) em que observam-se o dobramento das rochas, que ocorre de acordo com a foliação do gnaisse granítico.

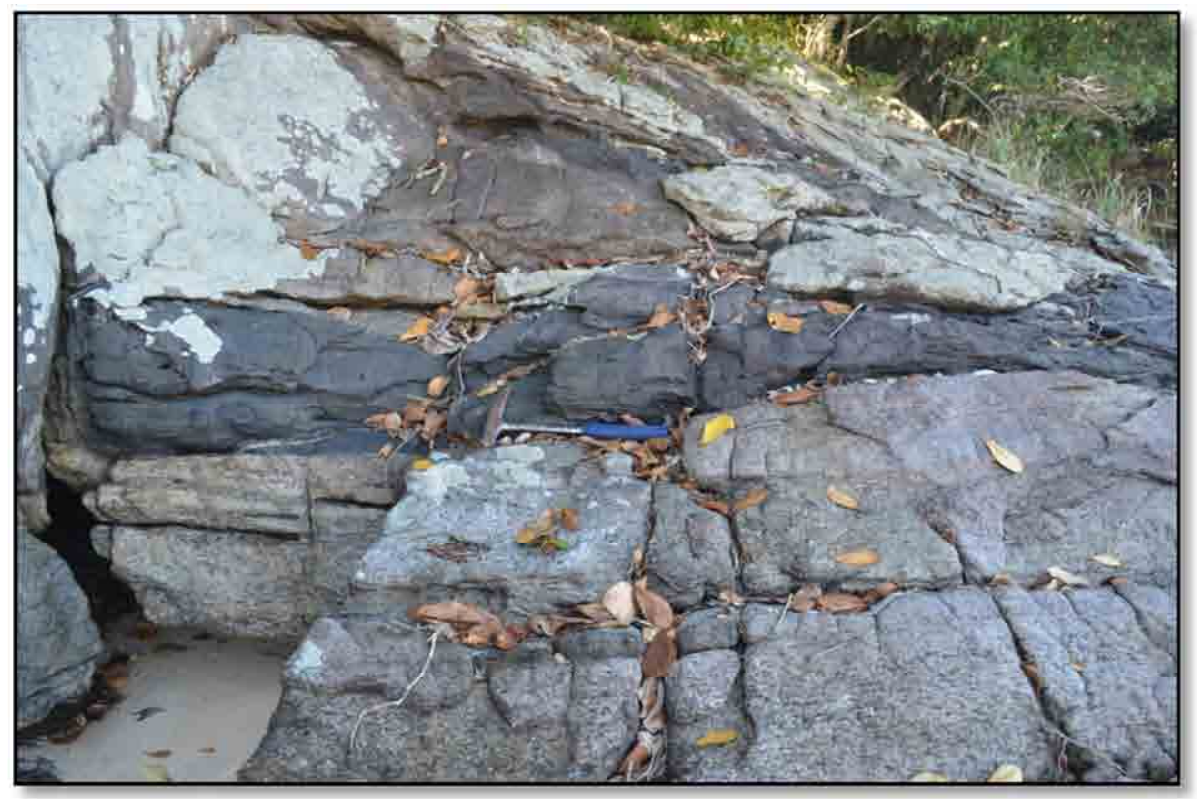

Figura 5.1.4.3 - observa-se a presença de um dique sin-plutônico no biotita gnaisse. 
5.1.5. Geossítio Monzogranito Ilha Anchieta

Localização (UTM): 0492073/ 7396054 (Figura 5.1.5.1)

Tipo: Ponto

Acesso: A Ilha Anchieta está localizada em frente à praia da Enseada e o Saco da Ribeira, a $14 \mathrm{~km}$ do centro de Ubatuba. O acesso à ilha é feito por meio de embarcações que saem do píer do Saco da Ribeira ou da Enseada. O geossítio está localizado no final da trilha do Saco Grande, com distância de 2.600 m (ida e volta) e grau de dificuldade considerado médio.

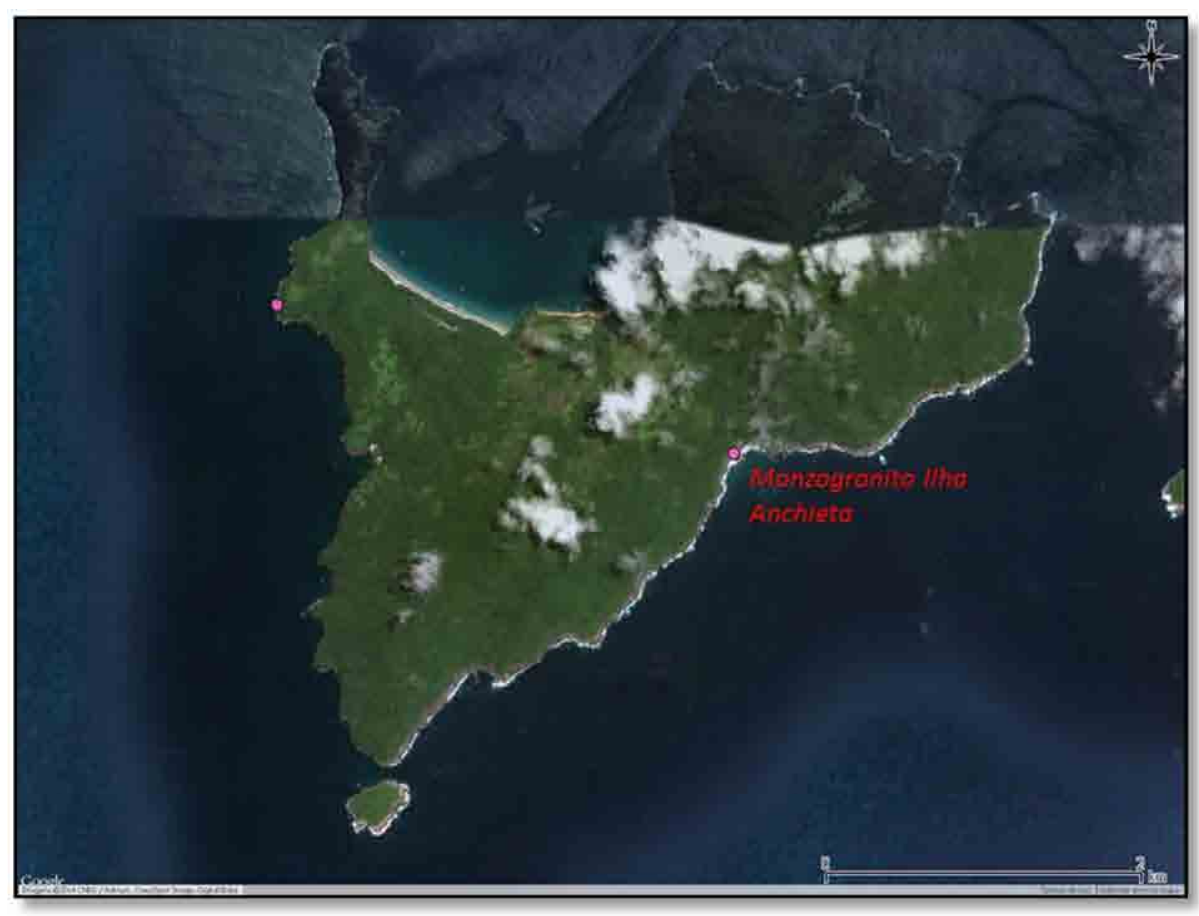

Figura 5.1.5.1 - Mapa de localização do geossítio Monzogranito Ilha Anchieta. Fonte: Google $\circledR$ in Qgis.

Dimensão: trata-se de um costão rochoso de aproximadamente 100 metros que se estende ao longo da costa.

Unidade no mapa da CPRM (2006): NP3a y1lia - granitos foliados calcialcalinos, tipo I Ilha Anchieta (ia).

Litotipos observadas no geossítio: biotita-hornblenda granito. 
Justificativa do valor científico:

O geossítio "Monzogranito Ilha Anchieta", de interesse ígneo e tectônico, registra os estágios finais da aglutinação do Gondwana, representados pela Orogenia Búzios, o último evento antes da abertura do Atlântico Sul.

\section{Elementos principais de interesse:}

O afloramento é caracterizado por um extenso costão rochoso de aproximadamente 100 metros de comprimento que se estende ao longo da costa (Figura 5.1.5.2a/b). O principal litotipo é o biotita-hornblenda monzogranito porfirítico, leucocrático com megacristais de microclínio tabulares, com dimensão máxima entre 2 e $4 \mathrm{~cm}$ em matriz de granulação média, e enclaves de minerais máficos (biotita e hornblenda e minerais acessórios, como zircão, titanita, apatita, Allanita) (Figura 5.1.5.3a/b/c) (AZEVEDO SOBRINHO et al., $2008^{17}$ ).

No afloramento, são observadas feições de bandamento ígneo, com disposição de megacristais tabulares paralelos à foliação de fluxo magmático. A estratificação é uma alternância de porções finas, máficas equigranulares da rocha com porções de quartzo monzogranito "típico" e passando gradualmente por rochas félsicas (AZEVEDO SOBRINHO et al., 2011, 2008) (Figura 5.1.5.4a/b). Estas feições, de acordo com o mesmo autor, podem ter sido desenvolvidas no fundo de uma câmara magmática sobre um substrato quase horizontal, em que o pluton estava sujeito à inclinação leste, evidenciado pela atitude das camadas (com orientação geral N-S mergulhando para E), que foram afetadas por uma falha normal.

No local, observam-se também duas famílias de fraturas que formam um ângulo de $90^{\circ}$ e a presença de finos concordantes às fraturas orientadas N60E (Figura $5.1 .5 .5 \mathrm{a} / \mathrm{b} / \mathrm{c}$ ).

O Monzogranito llha Anchieta, datado em $500 \mathrm{Ma}$ (U-Pb em zircões, Azevedo Sobrinho et al., 2011) é um corpo intrusivo ao Charnockito Ubatuba de $\sim 565$ (U-Pb em zircões, AZEVEDO SOBRINHO et al., op. cit.). Esta idade evidencia que o monzogranito corresponde a uma das idades magmáticas mais jovens do embasamento cristalino do estado de São Paulo. Portanto, estas rochas foram

\footnotetext{
17 AZEVEDO SOBRINHO, J.M.; JANASI, V.A.; SIMONETTI, A.; SANTORO, J.; DINIZ, H.N. Granito Ilha Anchieta extensão do magmatismo tardio à Orogênese Búzios no estado de São Paulo. Trabalho apresentado no XLIV Congresso Brasileiro de Geologia. Curitiba, PR, 2008. 
também afetadas por eventos extensionais que afetaram o cinturão de granitos potássicos e rochas máficas associadas com idades cambrianas (520-500 Ma), da Província da Mantiqueira.

Outros tipos de interesse: Didático (nível universitário)

Uso potencial: Científico, didático e turístico.

Vulnerabilidade: Natural (baixa)

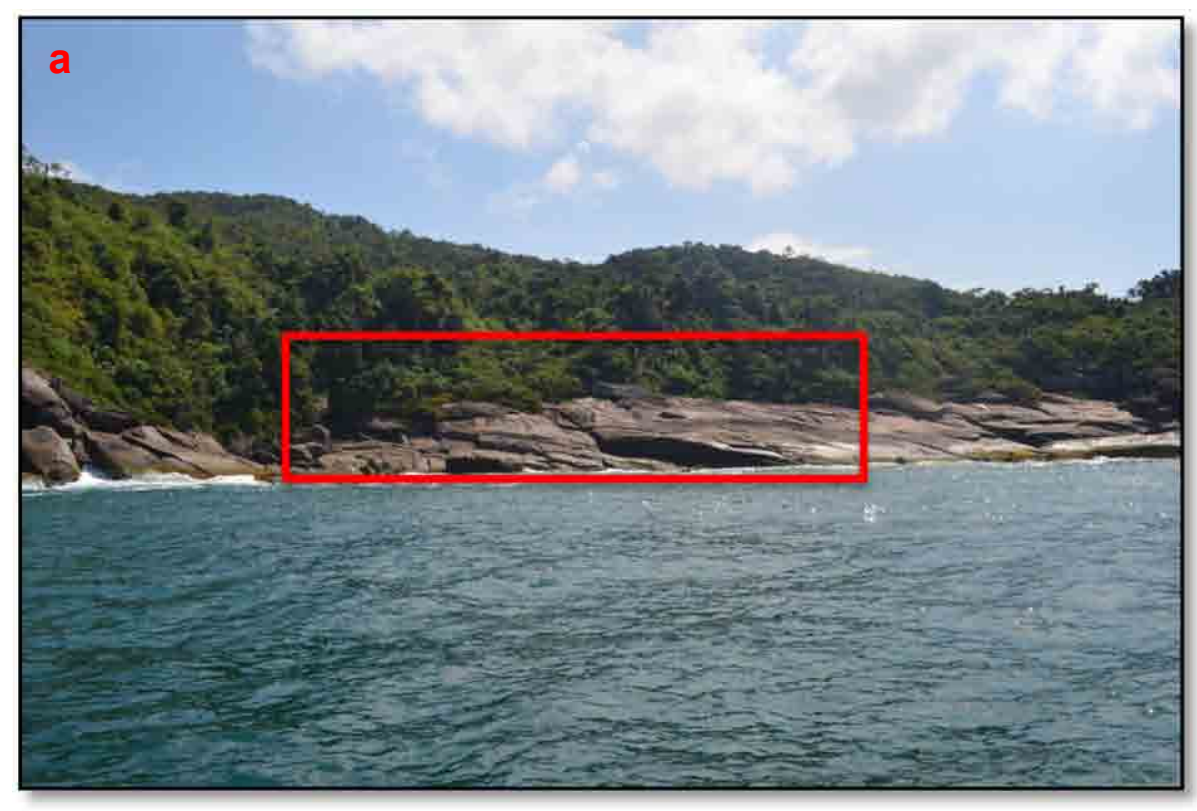

Figura 5.1.5.2a - Vista do mar do geossítio Monzogranito Ilha Anchieta. (Foto: Maria da Glória Motta Garcia). 


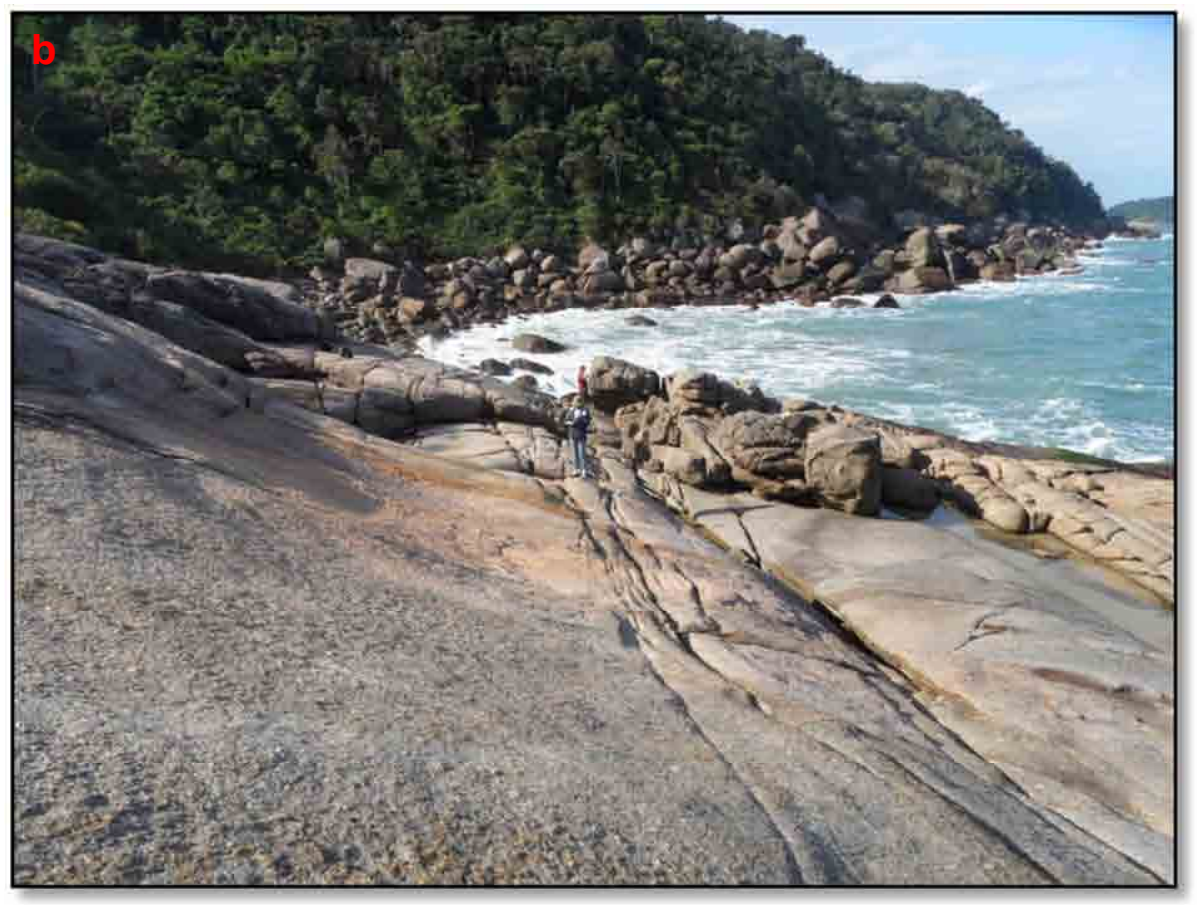

Figura 5.1.5.2b - Vista local do afloramento, que se estende por aproximadamente 100 metros ao longo da costa. (Foto: Maria da Glória Motta Garcia).

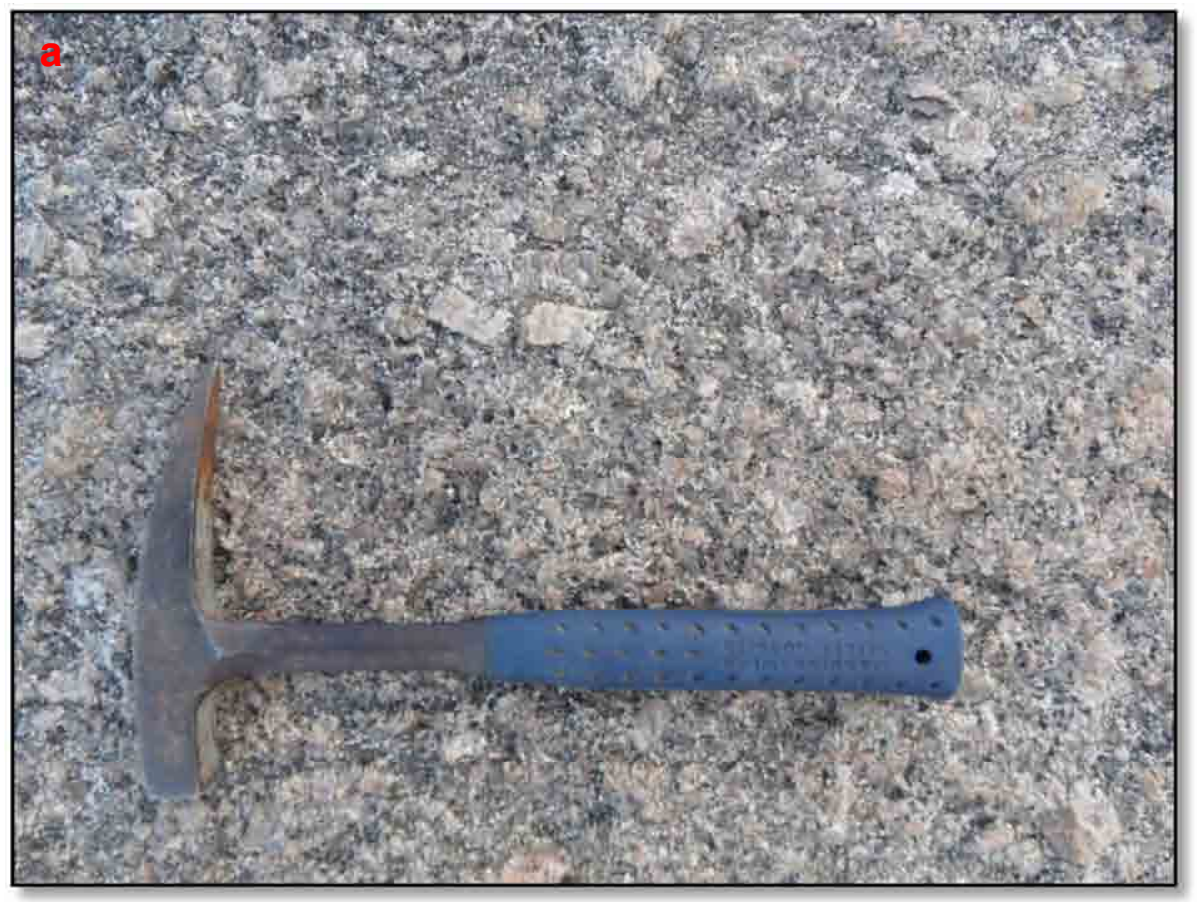

Figura 5.1.5.3 - Imagens de algumas estruturas observadas no geossítio Monzogranito Ilha Anchieta: a) detalhe do principal litotipo observado, o biotita-hornblenda monzogranito. Notase a presença de megacristais de microclínio que ocorrem com formas tabulares, com dimensão entre 2 e 4 cm. (Foto: Maria da Glória Motta Garcia). 

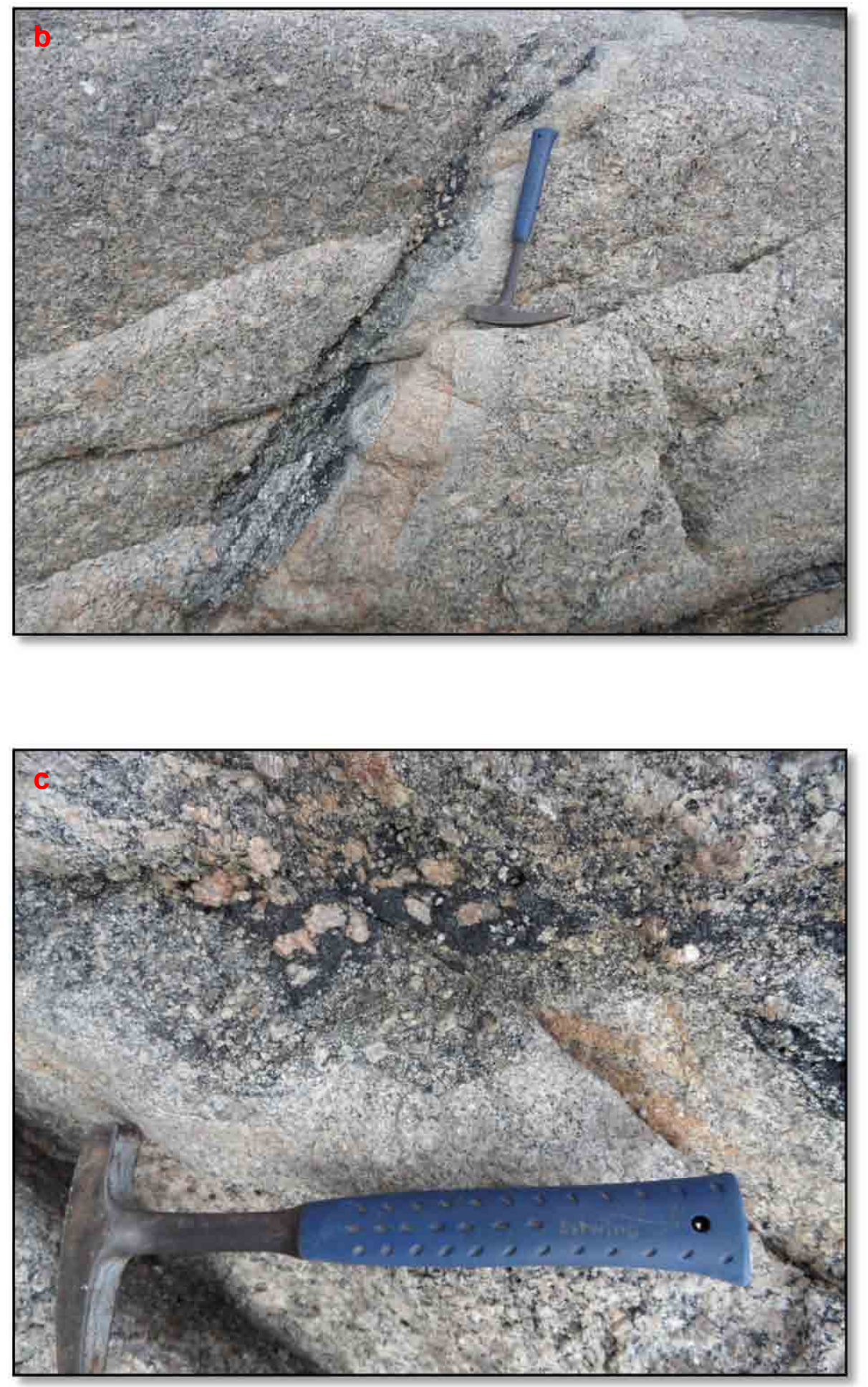

Figura 5.1.5.3 - Imagens de algumas estruturas observadas no geossítio Monzogranito Ilha Anchieta: b) e c) observa-se a concentração de alguns minerais como quartzo e feldspatos e minerais máficos como biotita. (Fotos: Maria da Glória Motta Garcia) 

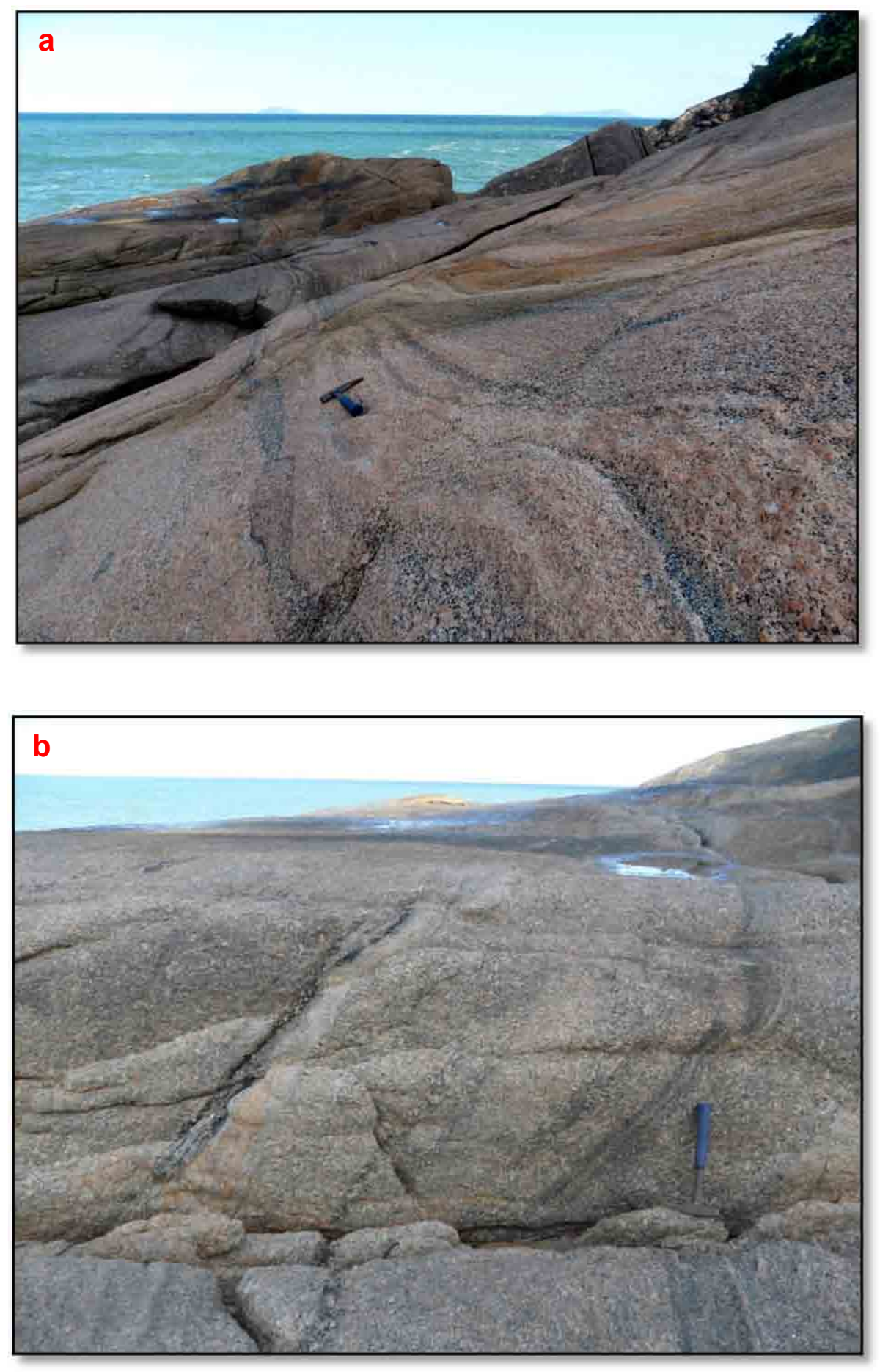

Figura 5.1.5.4 - a) Estratificação observada no quartzo monzogranito, com alternância de porções máficas da rocha para poções félsicas da rocha. Esta alternância, em geral ocorre com, aproximadamente, $10 \mathrm{~cm}$ de espessura; b) observa-se além da estratificação a atitude das camadas com orientação geral, N-S e mergulhos médios para E. (Fotos: Maria da Glória Motta Garcia) 

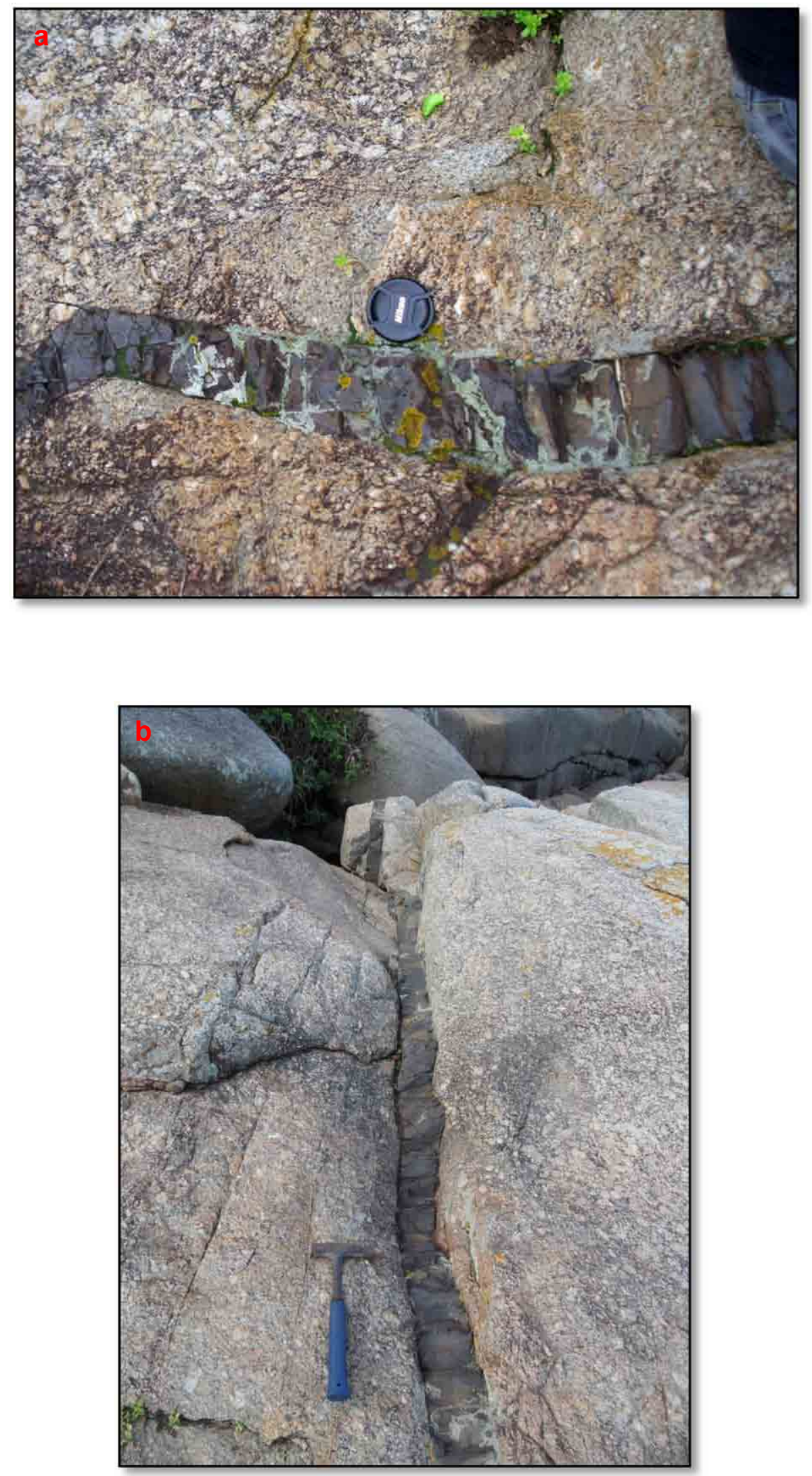

Figura 5.1.5.5 - a) e b) Diques máficos encontrados no geossítio. Observa-se em b, que este está concordante com o fraturamento NE-SW. (Foto: Maria da Glória Motta Garcia). 


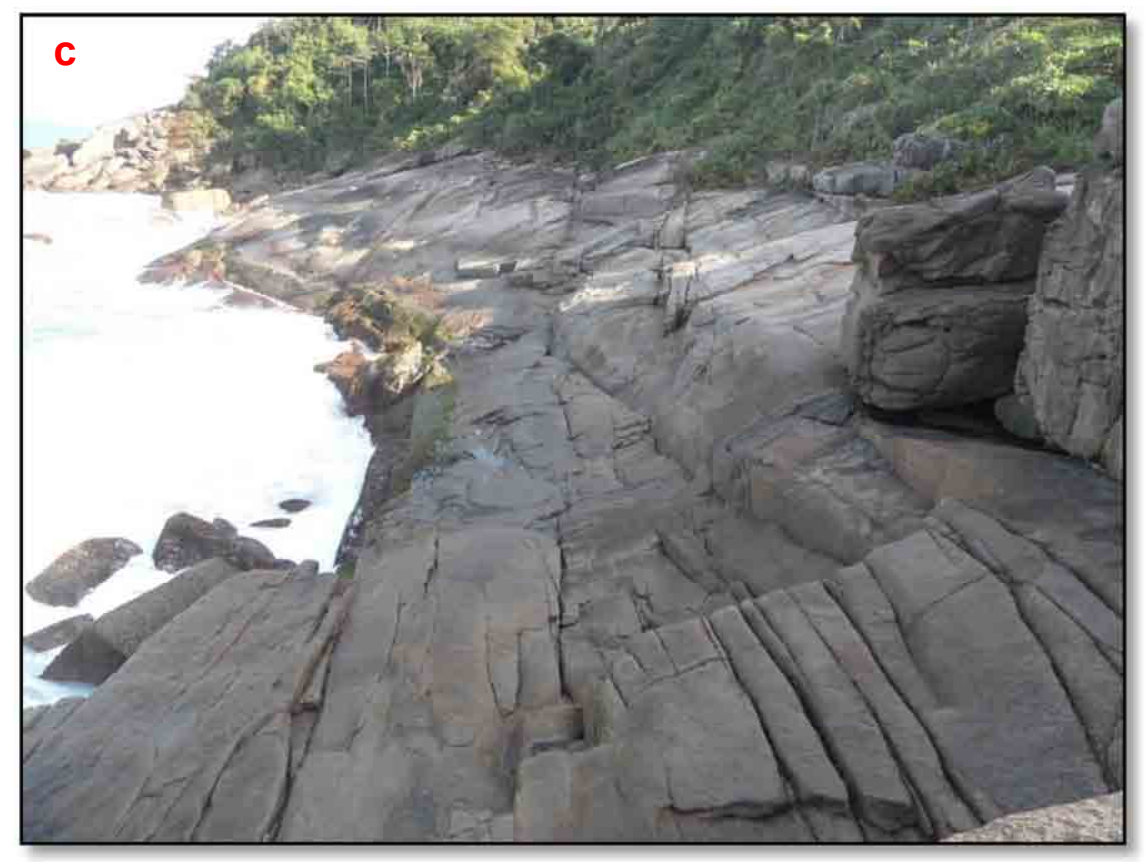

Figura 5.1.5.5 - c) Observam-se duas famílias de fraturas nas direções NE-SW, que formam um ângulo de $90^{\circ}$, (Foto: Maria da Glória Motta Garcia).

\subsubsection{Geossítio Gruta que Chora}

Localização (UTM): 0486539/ 7400941 (Figura 5.1.6.1)

Tipo: Ponto

Acesso: a Gruta que Chora está localizada na Praia da Sununga (Figura 5.1.6.2) que fica no lado esquerdo da Praia do Lázaro, $15 \mathrm{~km}$ ao sul do centro de Ubatuba. $\mathrm{O}$ acesso é feito a partir da Rod. Governador Mário Covas (BR101) até a saída da praia do Lázaro no km 63,5 que dá acesso a Rua Jabuticabeira, que termina na praia. $\mathrm{O}$ acesso à Praia da Sununga é livre.

Dimensão: trata-se de uma gruta com cerca de um metro de abertura, formada em um costão rochoso que se estende por cerca de 200 metros.

Unidade no mapa da CPRM (2006): NP3ay2Cub - Charnockito Ubatuba

Principais litotipos observadas no geossítio: granito foliado localmente porfirítico. 


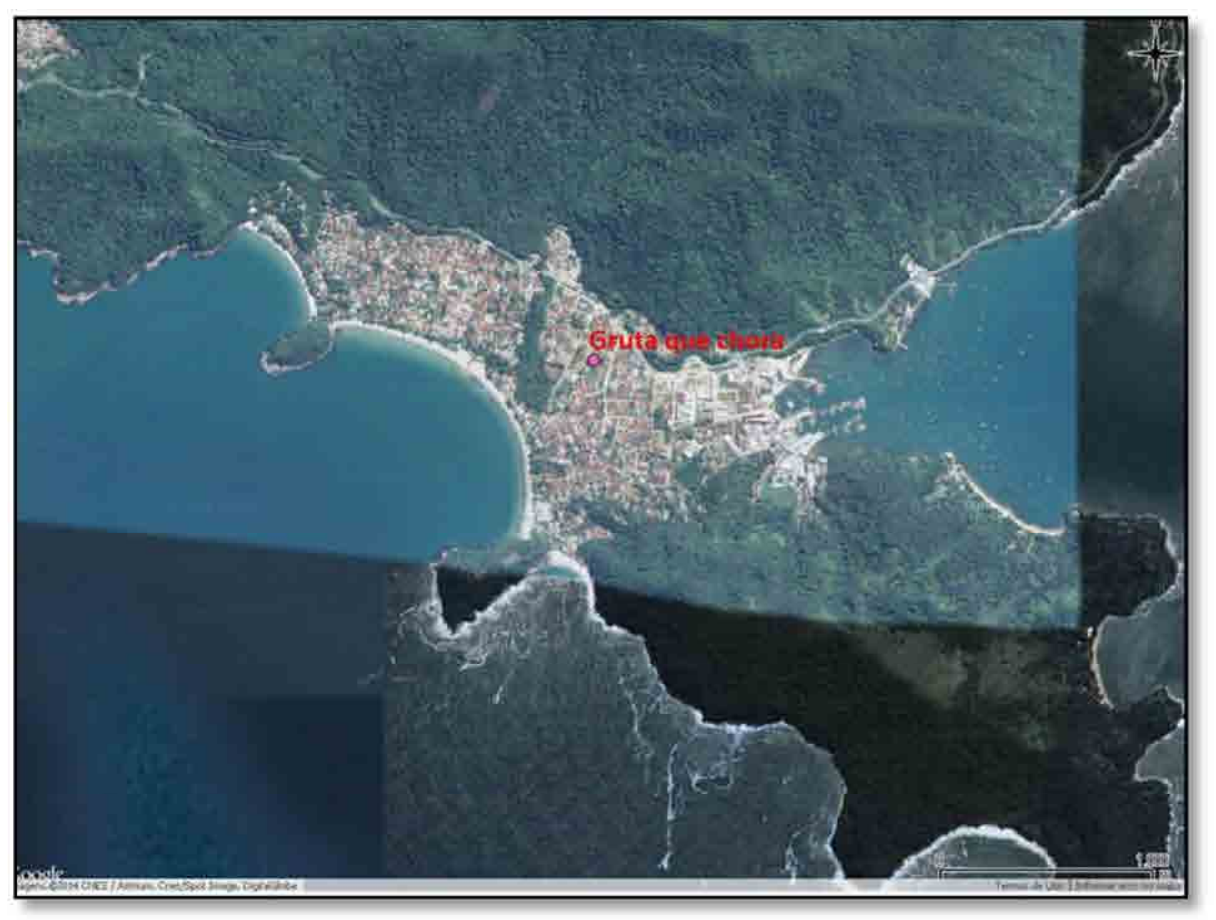

Figura 5.1.6.1 Mapa de localização do geossítio Gruta que chora. Fonte: Google ${ }^{\circledR}$ in Qgis.

Justificativa do valor científico:

Este geossítio é de interesse ígneo e tectônico. As feições encontradas no local ilustram os eventos que ocorrem durante a fase de aglutinação do Supercontinente, mais especificamente a fase de colisão, a qual se relaciona a ocorrência de diques sin-plutônicos.

No geossítio também são encontradas feições que ilustram os eventos extensionais relacionados com a fragmentação do Gondwana e a abertura do Oceano Atlântico no Jurássico Superior/ Cretáceo Inferior (HASUI, 2010). As fases iniciais de abertura do Atlântico foram marcadas por fraturamento onshore e offshore seguidos por eventos magmáticos que ocorreram em duas fases distintas: (i) representada por diques básicos e intermediários, cuja colocação foi controlada pelas estruturas neoproterozóicos e pela Junção Tríplice do Paraná e (ii) representada por stocks e diques de rochas alcalinas (GARDA \& SCHORSCHER, 1996, COUTINHO, 2008), como apresentado no Capítulo 4. 
Elementos principais de interesse:

A Gruta que chora é uma caverna, formada pela sucessiva queda de blocos a partir de uma fratura principal com orientação N45, subvertical, preenchida por dique basáltico de aproximadamente 3 metros de espessura que aflora no teto da gruta (Figura 5.1.6.3a/b/c/d). De acordo com Sjörberg $\left(1986^{18}\right.$ ) apud Lenhare (2011), cavernas desenvolvidas em granitos e gnaisses são classificadas como cavernas sólidas, desenvolvidas em juntas de alívio ou fraturas. Estas cavernas estão sujeitas à ação dos agentes do intemperismo, que muitas vezes atuam tanto no processo de formação, quanto no aumento do espaço original e preenchimento. Segundo Lenhare (2011) este é o caso da Gruta que Chora que foi formada pela ação do mar.

No interior da gruta observa-se um gotejamento de água que percorre suas paredes; alguns pesquisadores atribuem a origem da água a uma nascente no topo da gruta (PLATIER, 2011). Também são ouvidos "estrondos" que são atribuídos à arrebentação do mar no costão rochoso.

Na Praia da Sununga o principal litotipo observado é um granito foliado com orientação N120 com mergulho para NE, com porções porfiríticas e granulação que varia de fina a grossa e concentrações locais de biotita. No local são encontrados diques de diferentes composições. Um dos diques é fragmentado de coloração preta, textura afanítica de aspecto vítreo, apresenta feições de contato plástico com a rocha encaixante e resfriamento rápido e são considerados sin-plutônicos. $O$ bandamento no interior deste dique apresenta dobras de fluxo e fragmentos da rocha encaixante. (GARDA, 1995; PIRES, 2011). Próximo a este dique observa-se a presença de um veio pegmatítico que corta parte do afloramento (Figura 5.1.6.4a/b).

Outros dois diques lamprófiros são encontrados próximos à gruta. Estes apresentam textura porfirítica e matriz formada por um material muito fino. Mello (2008) apresenta uma análise de suscetibilidade magnética dos diques da região de Ubatuba e, segundo o autor, os diques da Praia da Sununga apresentam tramas magnéticas normais, que comumente se relacionam à direção de fluxo magmático preenchendo fraturas. Localmente estes diques preenchem fraturas que possuem orientação N45 e N160. (Figura 5.1.6.5).

\footnotetext{
${ }^{18}$ SJÖBERG, R. A Proposal For a Classification System For Granitic Caves. Trabalho apresentado no $9^{\circ}$ Congresso Internacional de Espeleologia (anais). Barcelona, 1: 25-29, 1986. 
Outros tipos de interesse: histórico-cultural

Muitas lendas cercam a gruta e as mais contadas têm em comum a figura de uma serpente gigante. A primeira delas foi publicada em um artigo no jornal "A Tribuna", na década de 50, pelo historiador Francisco Martins dos Santos (Figura 5.1.6.6). Segundo o pesquisador a gruta servia de abrigo para uma enorme serpente que se alimentava dos tripulantes das navegações que passavam pelo local. Em uma viagem de Bertioga a Ubatuba, o Padre Anchieta teve conhecimento da história e foi até a gruta. Chegando lá, usou a água benta que levava consigo afastando a serpente do local. Segundo a lenda, a água usada por Padre Anchieta formou um grande depósito que até os dias atuais permeiam pelas paredes da cavidade. Por esse motivo muitos turistas visitam o local em busca da água santa que tem o poder de afastar o mal. A segunda lenda conta a história de uma mulher que se apaixonou por um caiçara. Todos os dias os dois se encontravam na gruta. Pouco tempo depois, Marcelina descobriu que o jovem por quem havia se apaixonado se transformava na serpente que assombrava os pescadores e viajantes do local. Certo dia a serpente entrou para gruta e nunca mais saiu. Marcelina todos os dias visitava o local na esperança de encontrar seu amor. Segundo a lenda as gotas que caem na gruta são as lágrimas da jovem (Figura 5.1.6.7a/b).

Uso potencial: Didático (nível universitário), científico, e turístico.

Vulnerabilidade: Natural (baixa). 


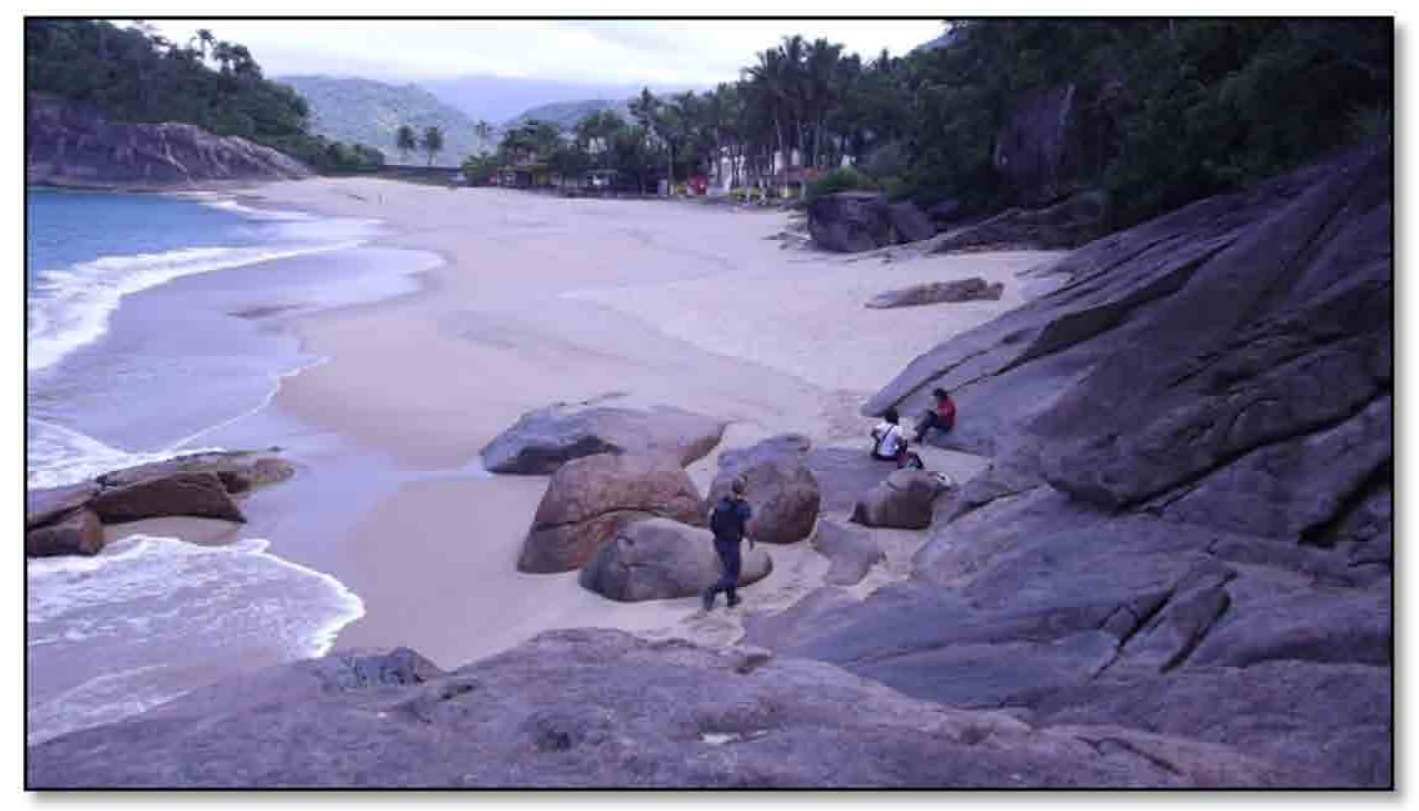

Figura 5.1.6.2 - Praia da Sununga vista do geossítio.

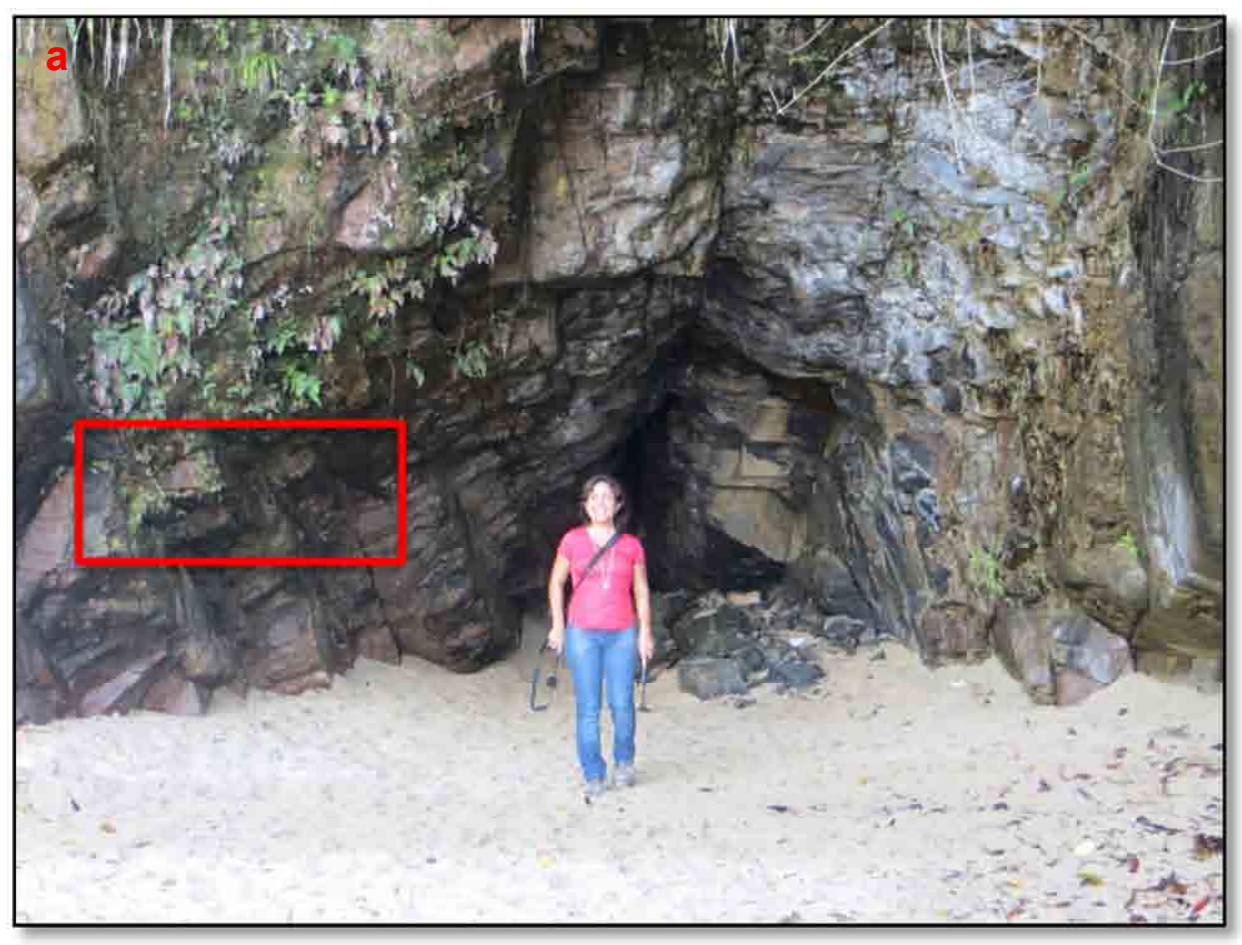

Figura 5.1.6.3 - a) Vista para a entrada da Gruta que Chora. (Foto: Fernanda Reverte). 


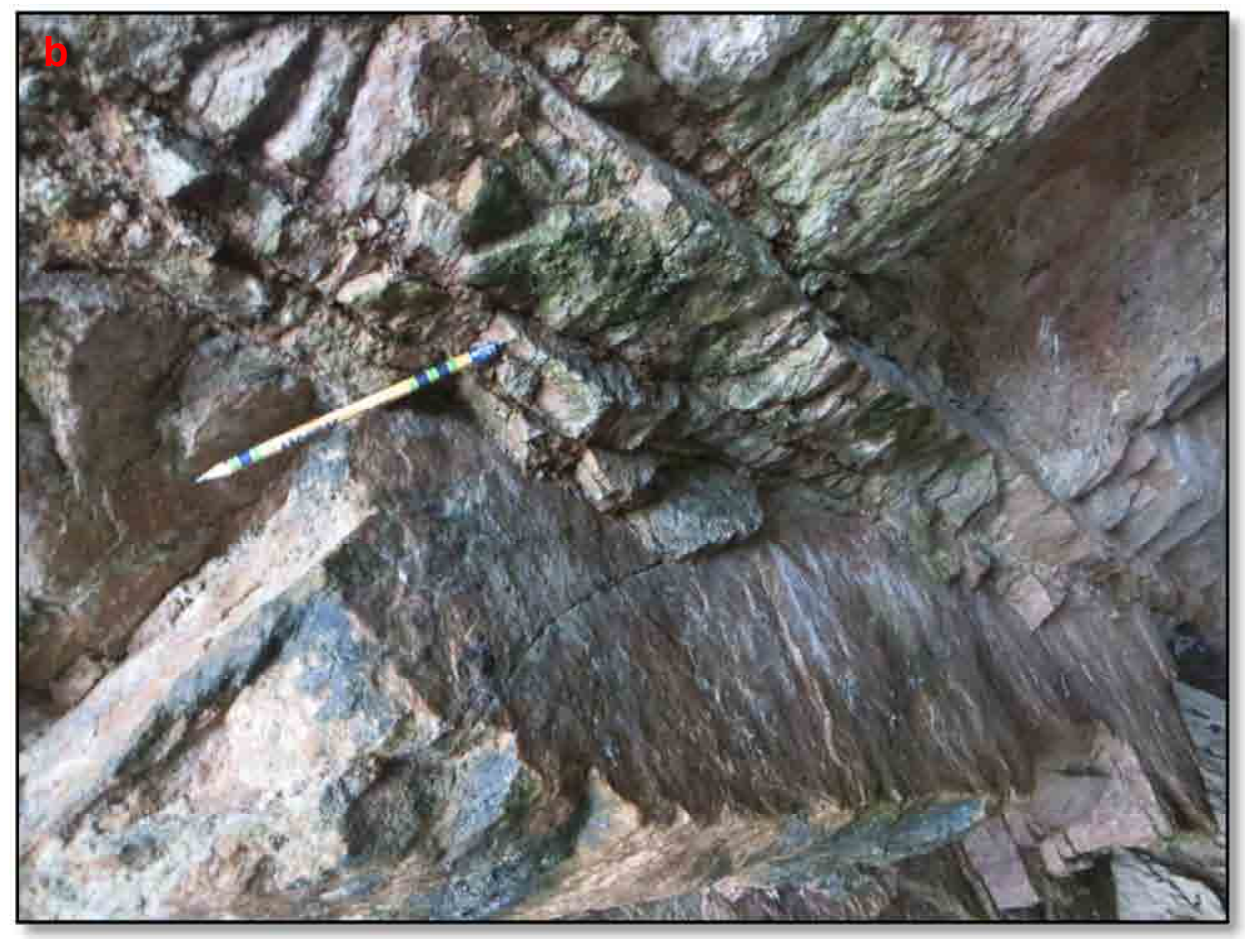

Figura 5.1.6.3 - b) Detalhe da foto (a) em que se observam famílias de fraturas formando um ângulo de $+/-90^{\circ}$ a partir da fratura principal N45. (Foto: Fernanda Reverte).

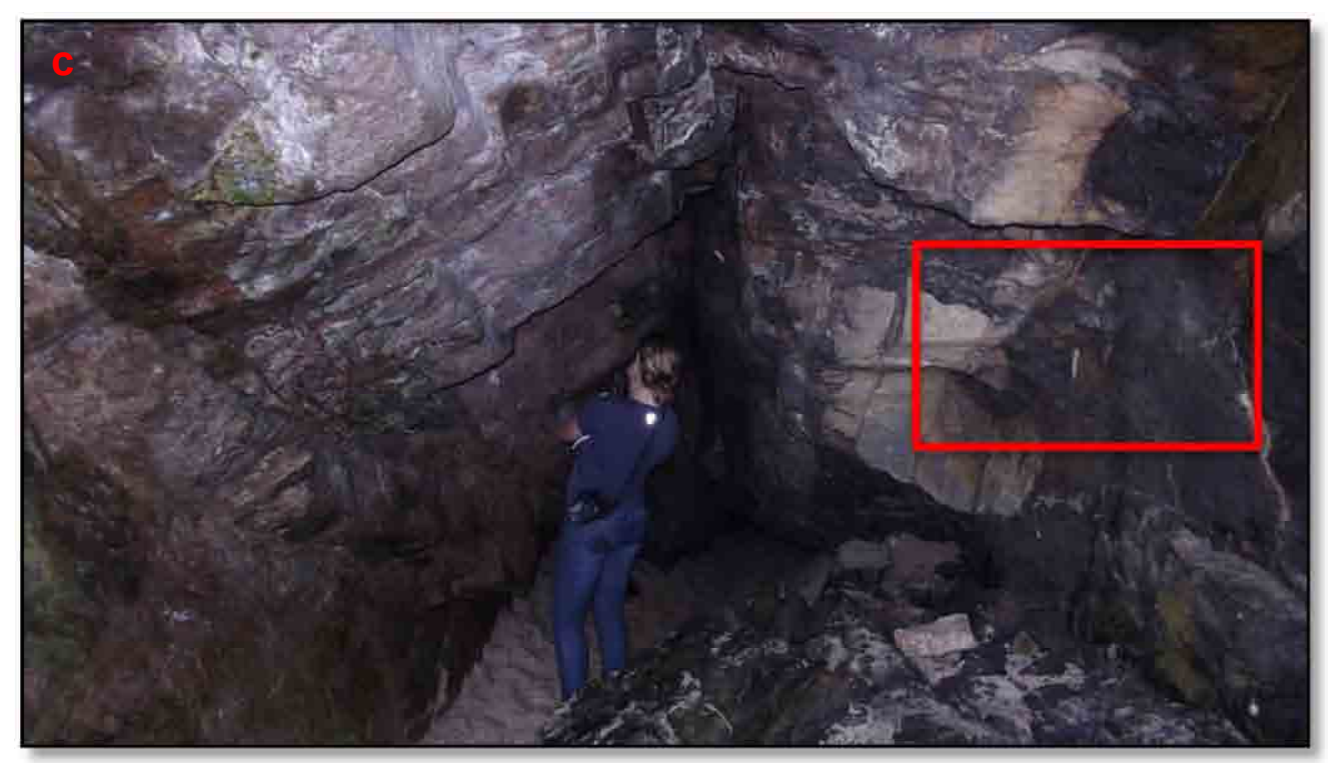

Figura 5.1.6.3 - c) Vista interna da Gruta que Chora, no teto observa-se um dique basáltico e no chão, muitos blocos caídos, que são formados a partir das fraturas observadas na gruta. (Foto: Vanessa Mucivuna). 


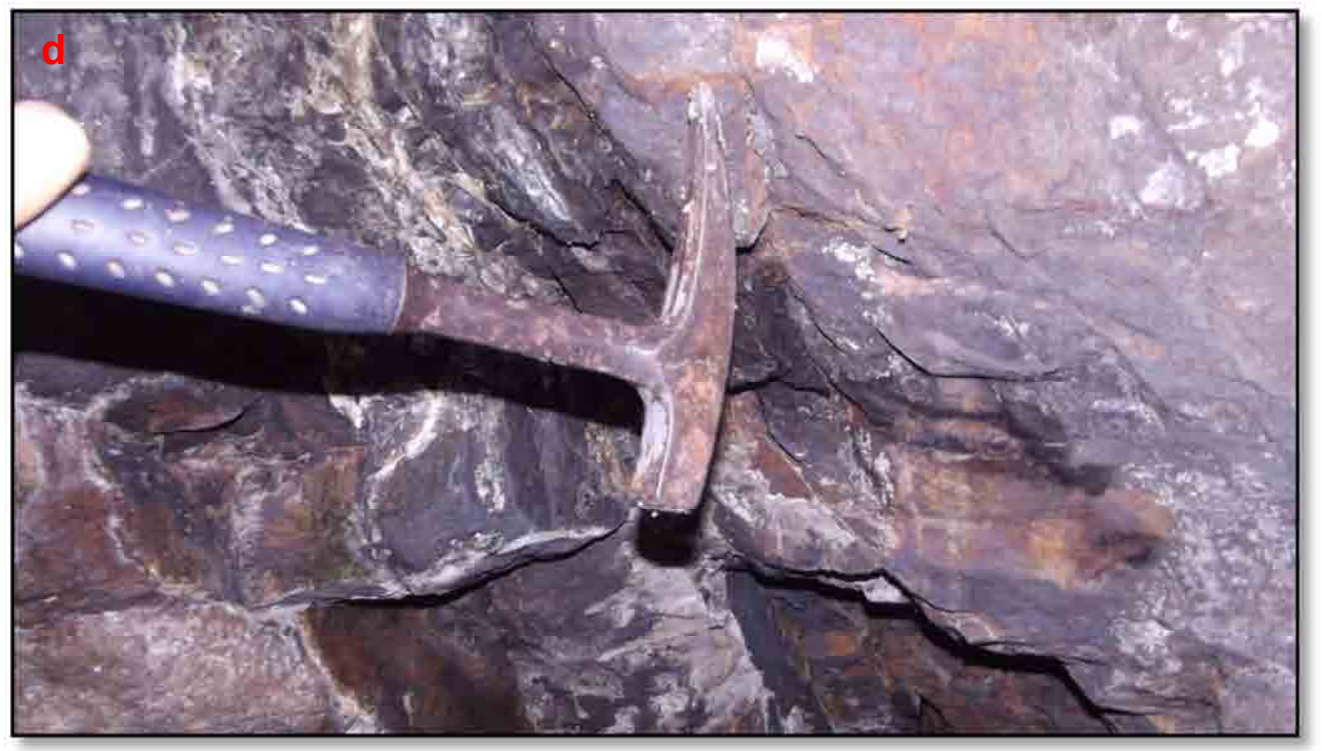

Figura 5.1.6.3 - d) Dique basáltico no teto da gruta. (Foto: Vanessa Mucivuna).

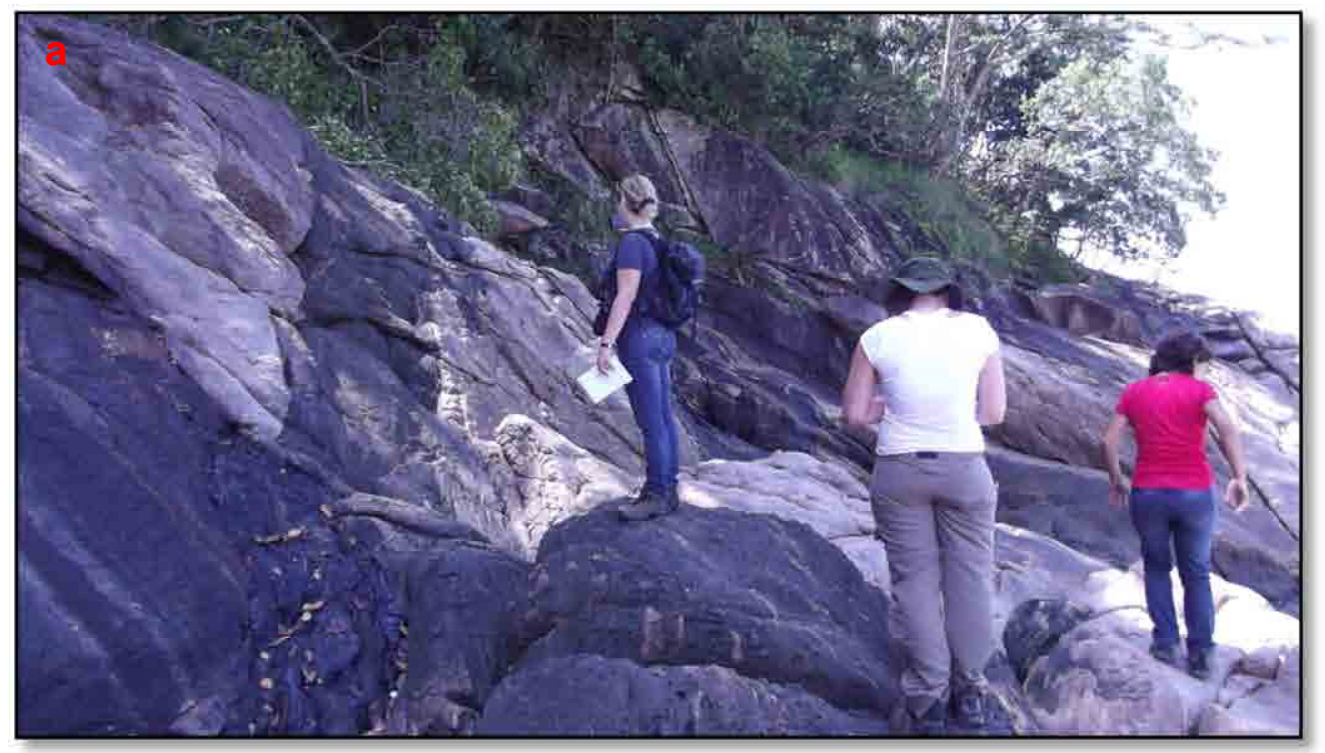

Figura 5.1.6.4 - a) Vista para o afloramento na Praia da Sununga, em que se observa a presença de diques máficos, interpretados como sin-plutônicos em contato com o granito. Estes diques apresentam porções da rocha encaixante e as estruturas de deformação. (Foto: Vanessa Mucivuna) 


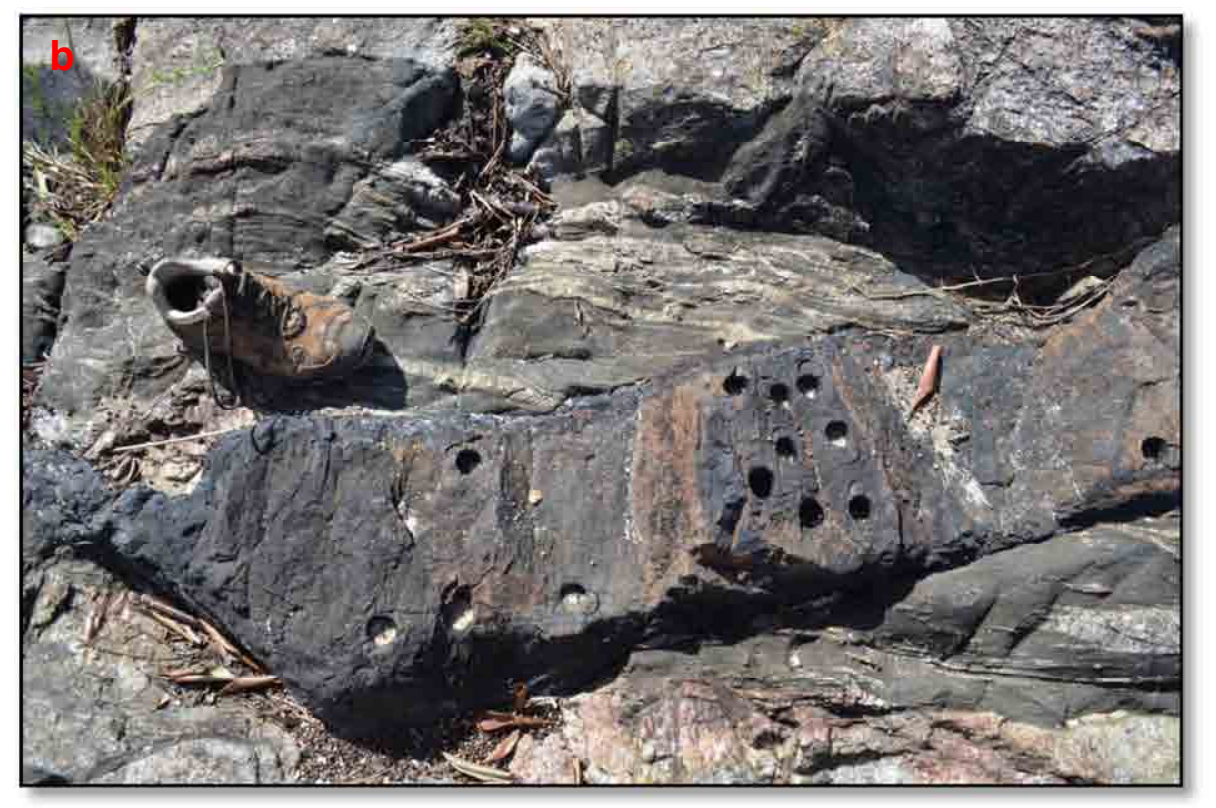

Figura 5.1.6.4 - b) No afloramento pode-se observar as relações de contato entre os diferentes tipos de rochas: o granito, intrudido por diques rompidos (sin-plutônicos) com porções da rocha encaixante, que são cortados por um dique máfico.

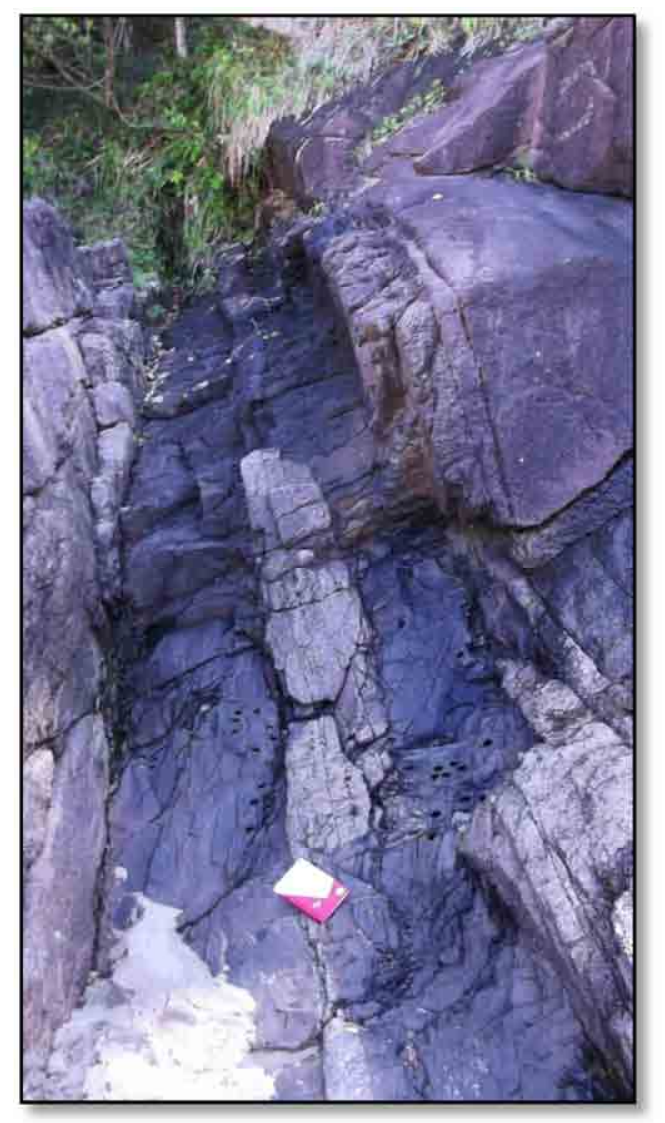

Figura 5.1.6.5 - Diques lamprófiros localizados próximo a Gruta que Chora (MELLO, 2008). (Foto: Vanessa Mucivuna) 


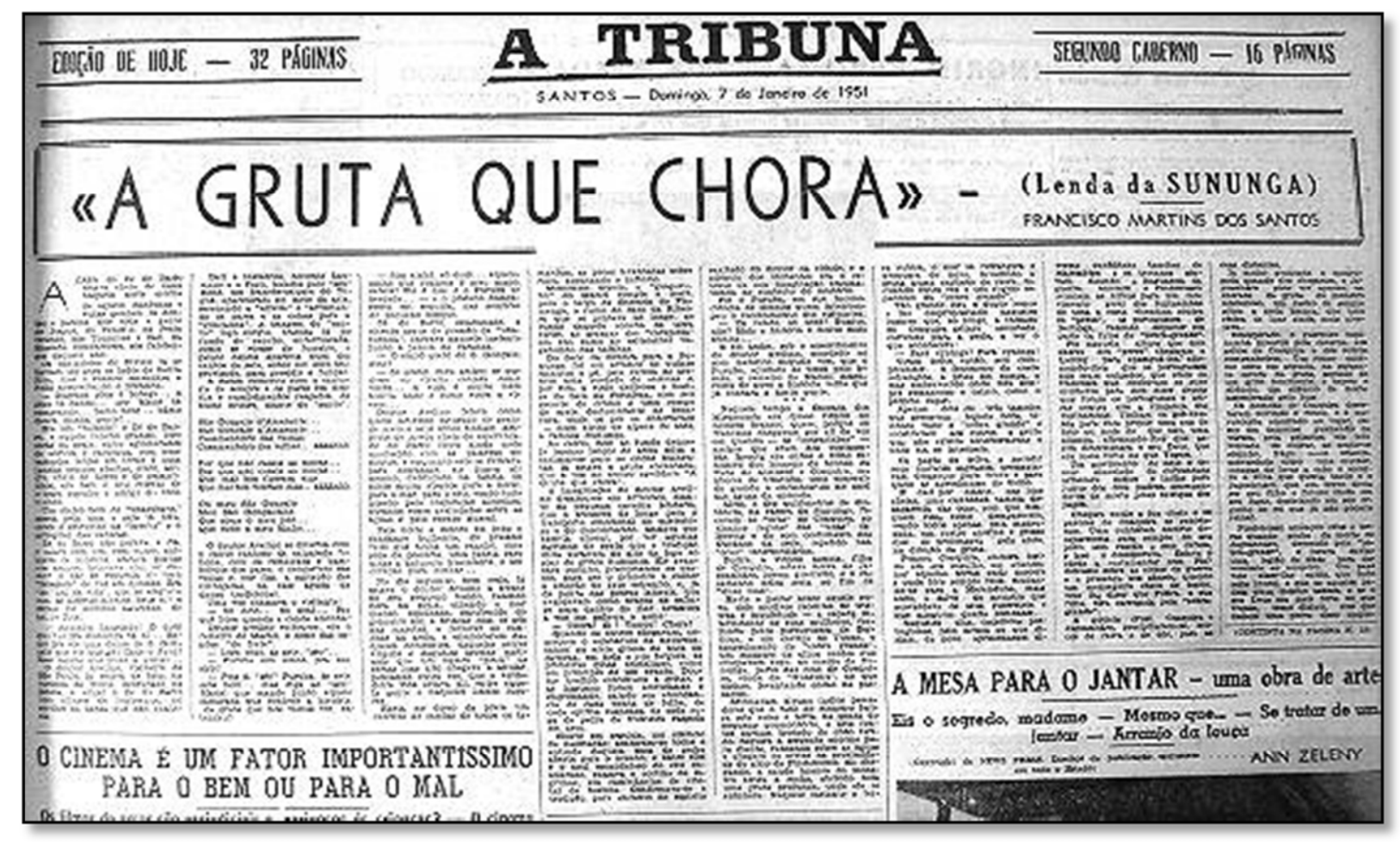

Figura 5.1.6.6 - Primeira publicação sobre as lendas da Gruta que Chora no jornal "A Tribuna" em 1951. Artigo: Francisco Martins dos Santos. Fonte: http://www.atribuna.com.br/.

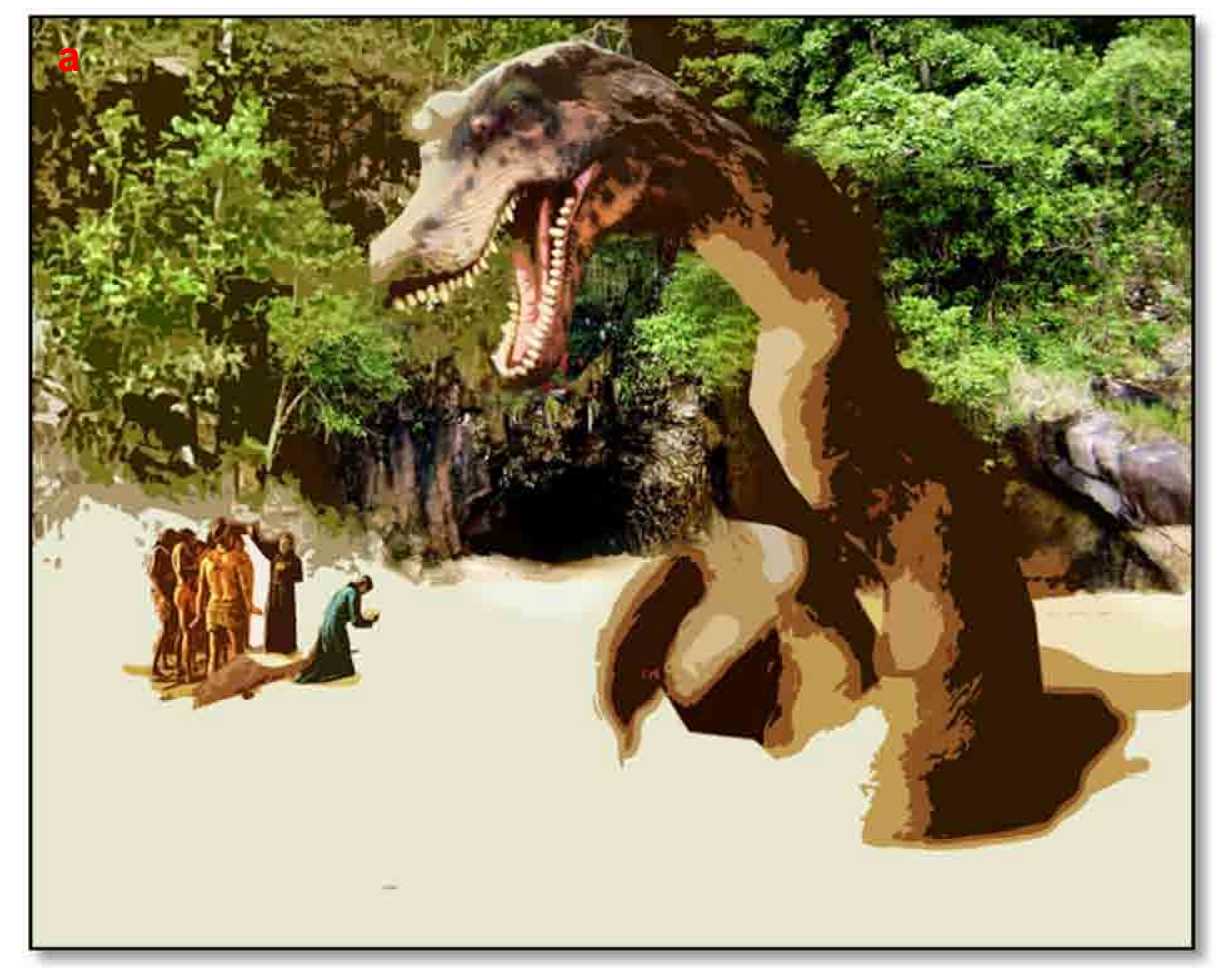

Figura 5.1.6.7 - a) llustração da lenda do Padre José de Anchieta em frente a Gruta que Chora afastando a Serpente. Por: Luiz Pagano. Fonte: http://blemya.blogspot.com.br/. 


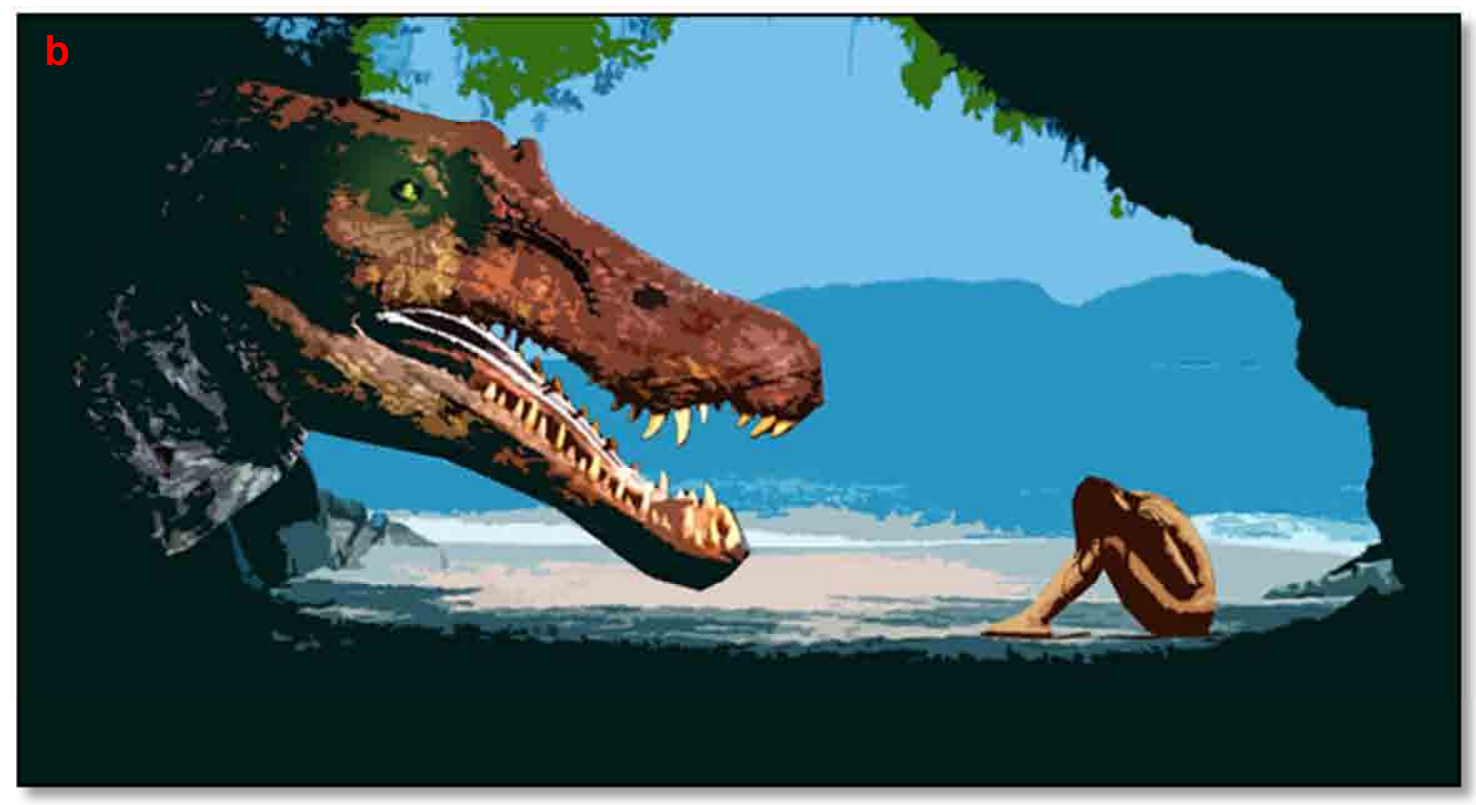

Figura 5.1.6.7 - b) Ilustração do encontro de Marcelina com a Serpente que habitava a gruta. Por: Luiz Pagano Fonte: http://blemya.blogspot.com.br/.

5.1.7. Geossítio Brecha Magmática Ilha Anchieta

Localização (UTM): 0492073/ 7396054 (Figura 5.1.7.1)

Tipo: Ponto

Acesso: A Ilha Anchieta está localizada em frente à praia da Enseada e o Saco da Ribeira, a $14 \mathrm{~km}$ do centro de Ubatuba. O acesso à ilha é feito por meio de embarcações que saem do píer do Saco da Ribeira ou da Enseada. O geossítio está localizado na porção ocidental da ilha entre a Praia do Sul e o Saco da Aroeira e pode ser acessado apenas de barco.

Dimensão: trata-se de um costão rochoso de aproximadamente 50m.

Unidade no mapa da CPRM (2006): NP3a y1lia - granitos foliados calcialcalinos, tipo I Ilha Anchieta (ia).

Principais litotipos observadas no geossítio: dique de diabásio, rochas charnockíticas e leucogranitos associados. 


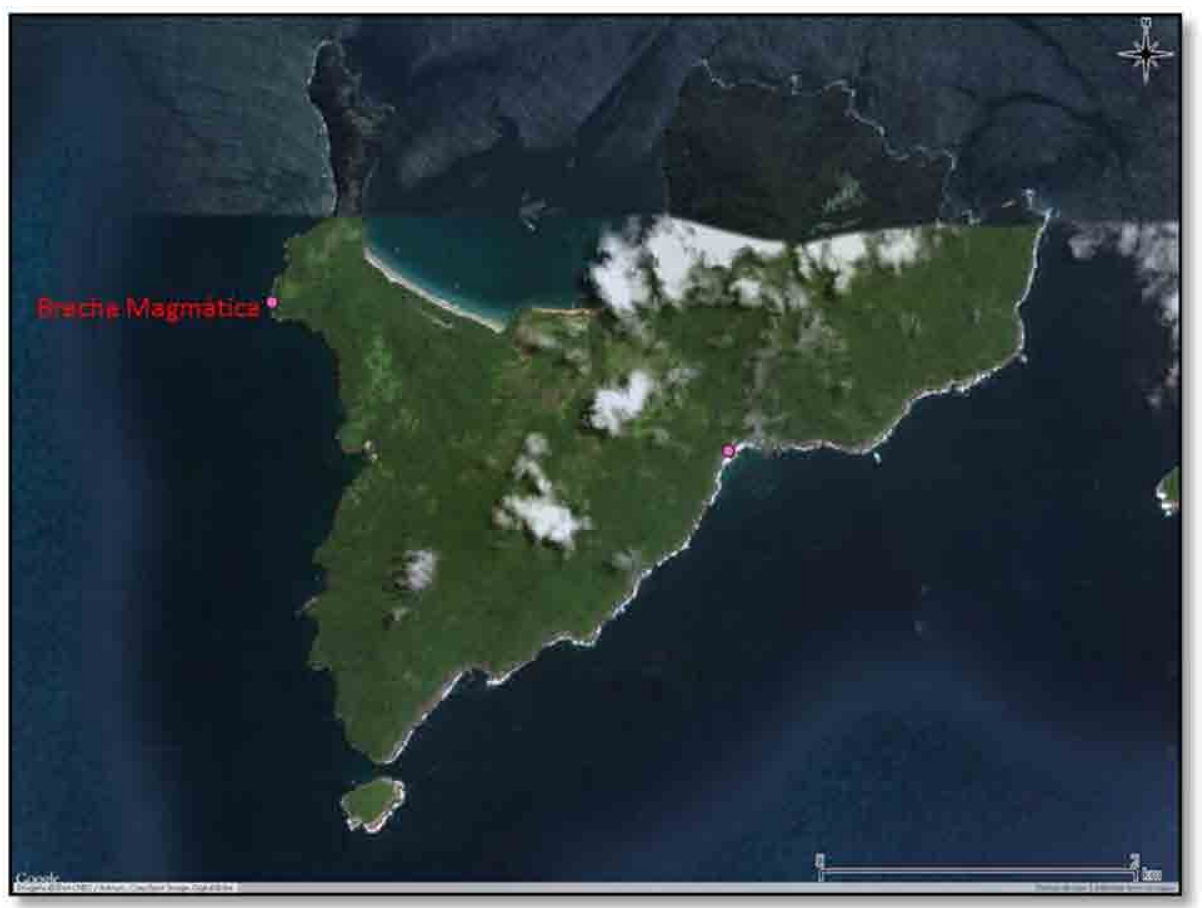

Figura 5.1.7.1 - Mapa de localização do geossítio Brecha Magmática. Fonte: Google $®$ in Qgis.

Justificativa do valor científico:

As feições encontradas no afloramento exemplificam os eventos magmáticos de derrames basálticos e alcalinos que resultaram na composição do Enxame de Diques da Serra do Mar durante o Cretáceo ( 140-134 Ma), descritos no capítulo 4. Estes eventos nos remetem ao último evento antes e às fases inicias de fragmentação (rifteamento) do Supercontinente Gondwana.

\section{Elementos principais de interesse:}

O geossítio apresenta interesse ígneo e tectônico. Trata-se de um costão rochoso de aproximadamente $50 \mathrm{~m}$ de comprimento, cujos principais litotipos observados são rochas charnockíticas e leucogranitos associados (Figura 5.1.7.2). No local encontra-se uma brecha magmática, produzida pela interação física/química dos magmas basálticos e os principais litotipos circundantes. A brecha é descrita por Azevedo Sobrinho (et. al., 2011) como uma série de blocos de tamanhos subangulares de charnockitos foliados e da rocha encaixante de composição granítica, formando um hibrido na rocha matriz de quartzo diorito, que são expostos por dezenas de metros (Figura 5.1.7.3a/b/c). Análises petrográficas, 
apresentadas pelo mesmo autor, sugerem que os blocos menores de granito incluídos no diabásio foram parcialmente derretidos (Figura 5.1.7.3d).

Próximo à brecha ocorrem restos de um dique de diabásio de aproximadamente 15 metros de largura, orientado N45W subvertical, concordante com o fraturamento NW. Segundo Garda (1996), este dique, no qual ainda são encontrados diversos enclaves de charnockito e leucogranitos, pode fazer parte do sistema de diques da região (Figura 5.1.7.4 a/b/c).

O geossítio ilustra diferentes eventos que ocorreram durante a história geológica enfocada. De acordo com Azevedo Sobrinho (2011), um primeiro evento magmático, durante o Proterozoico, teria formado as rochas charnockíticas ( 565 Ma) a partir da fusão parcial das rochas da crosta em alto grau. Estas rochas apresentam foliação em estado sólido e leucogranitos associados. Posteriormente, um pluton de quartzo monzogranito intrudido no charnockito formou o quartzo monzogranito predominantemente encontrado na ilha. A brecha magmática e a colocação do dique resultariam de derrames basálticos durante o magmatismo toleítico ( 190-130 Ma) que compõem enxame de diques da Serra do Mar, concomitantemente ao fraturamento conspícuo NE e NW.

Outros tipos de interesse: Didático (nível universitário).

Uso potencial: Científico e didático.

Vulnerabilidade: Natural (baixa). 


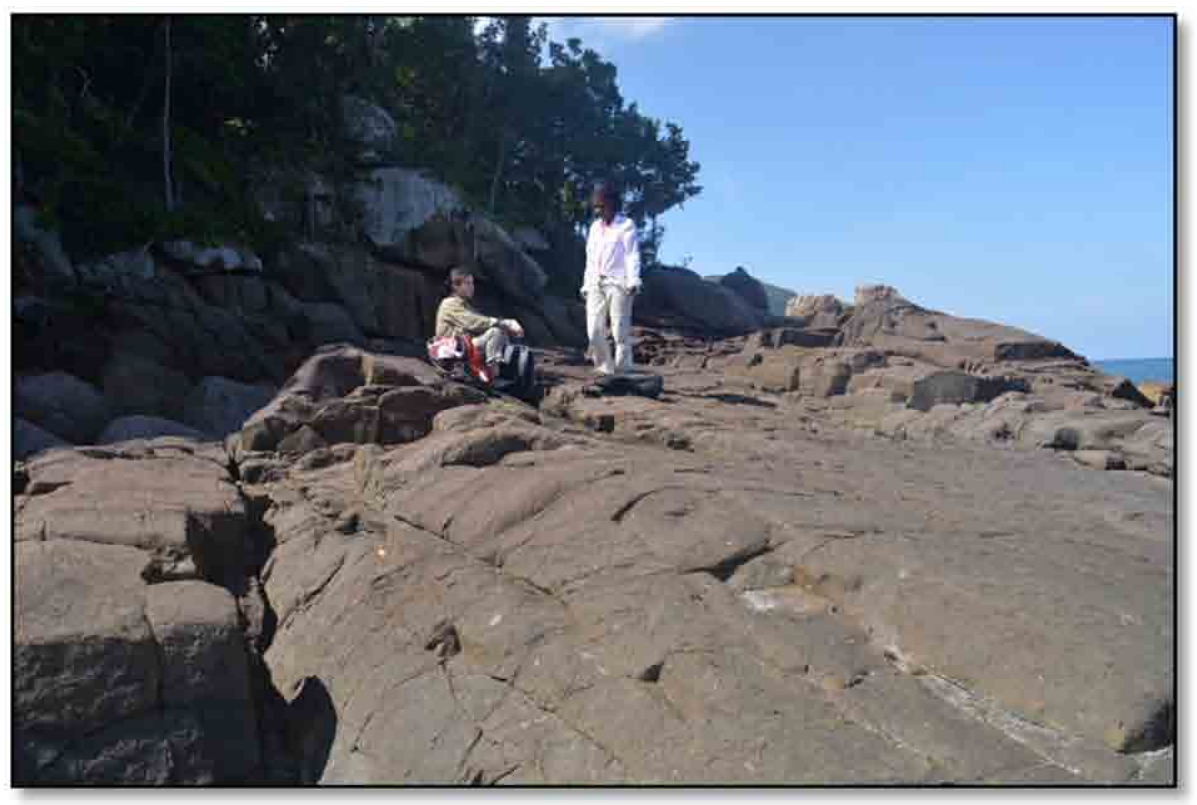

Figura 5.1.7.2 - Vista do afloramento com aproximadamente 50 metros de extensão em que se observa o charnockito Ubatuba - principal litotipo observado no afloramento. (Foto: Maria da Glória Motta Garcia).

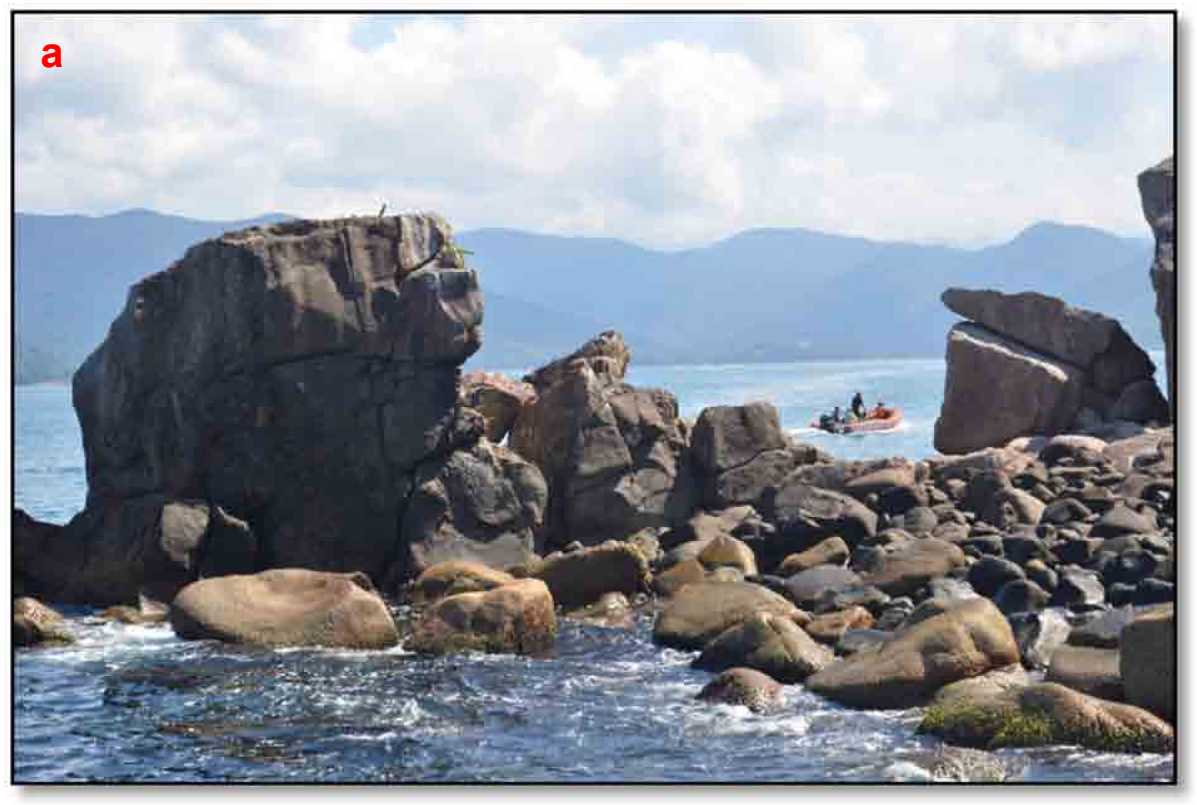

Figura 5.1.7.3 - a) A brecha magmática ocorre na forma de blocos grandes e médios que são produzidos por fraturamento. (Foto: Maria da Glória Motta Garcia). 

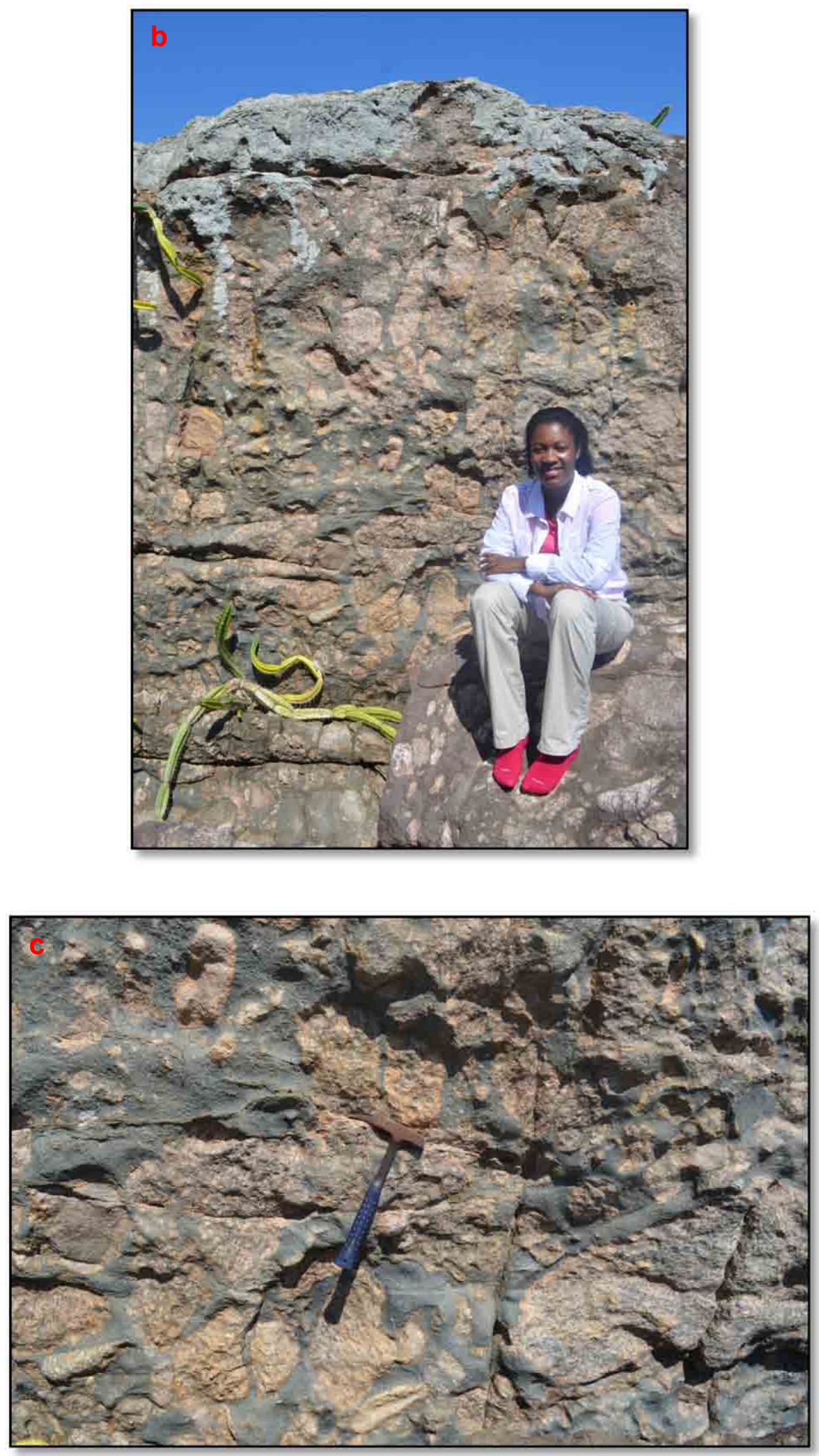

Figura 5.1.7.3 - b) e c) Blocos subangulares que compõem a brecha magmática, composta por charnockitos foliados e granitos formando um hibrido na rocha matriz de quartzo diorito. 


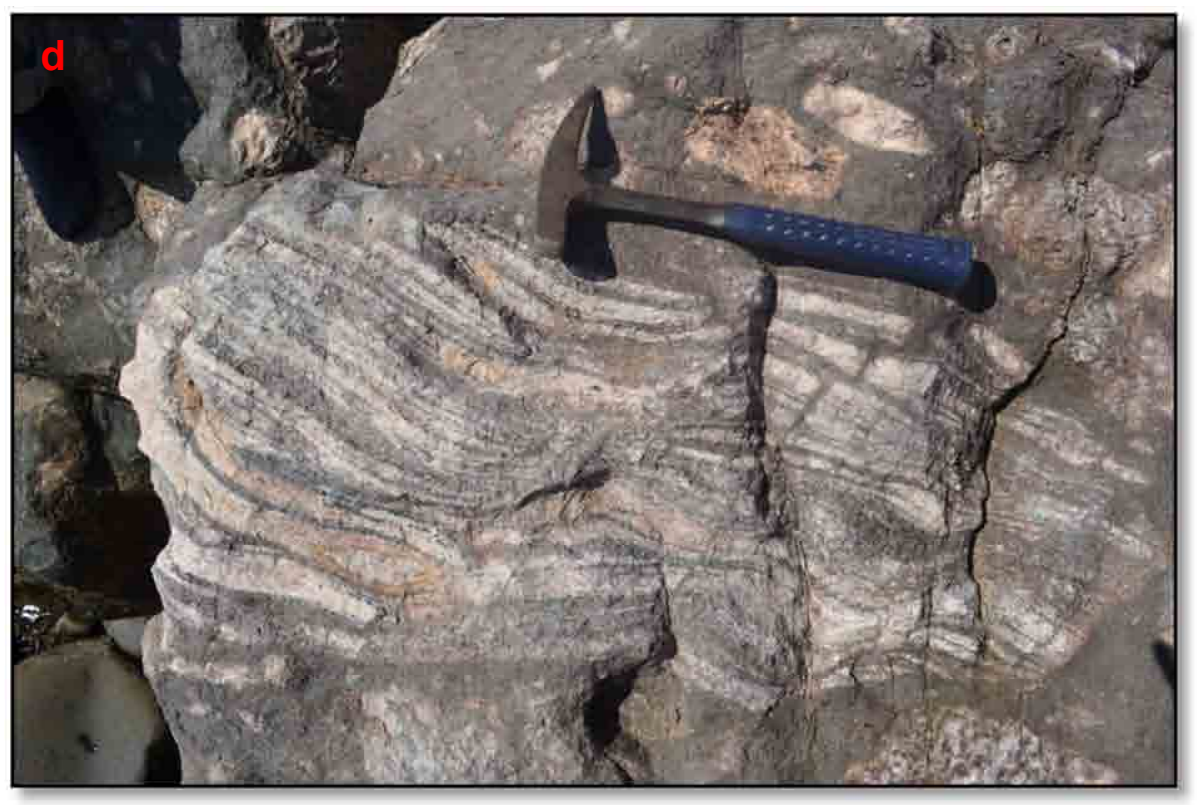

Figura 5.1.7.3 - d) Blocos subangulares de granito incluídos no diabásio foram parcialmente derretidos, e em algumas porções ocorrem como gnaisse.

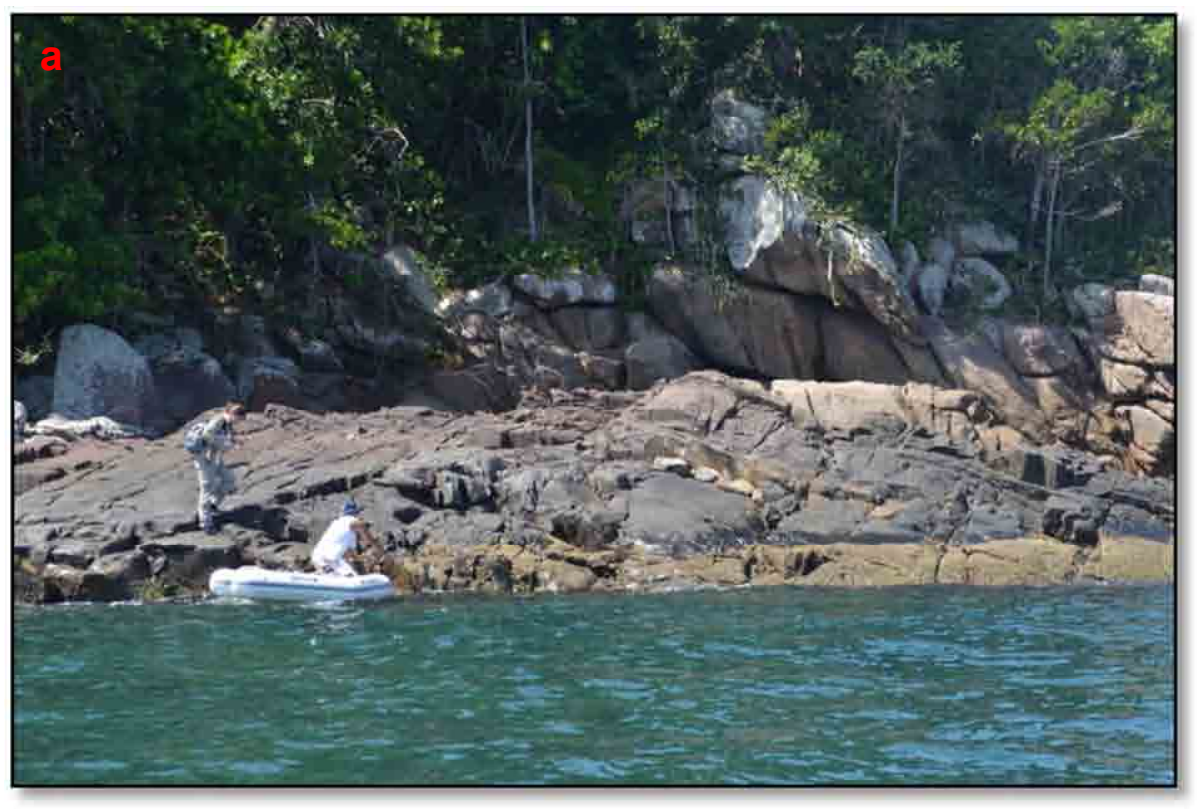

Figura 5.1.7.4 - a) Dique subvertical, orientado N45 concordante com a direção do falhamento NW (vista do mar). (Foto: Maria da Glória Motta Garcia). 

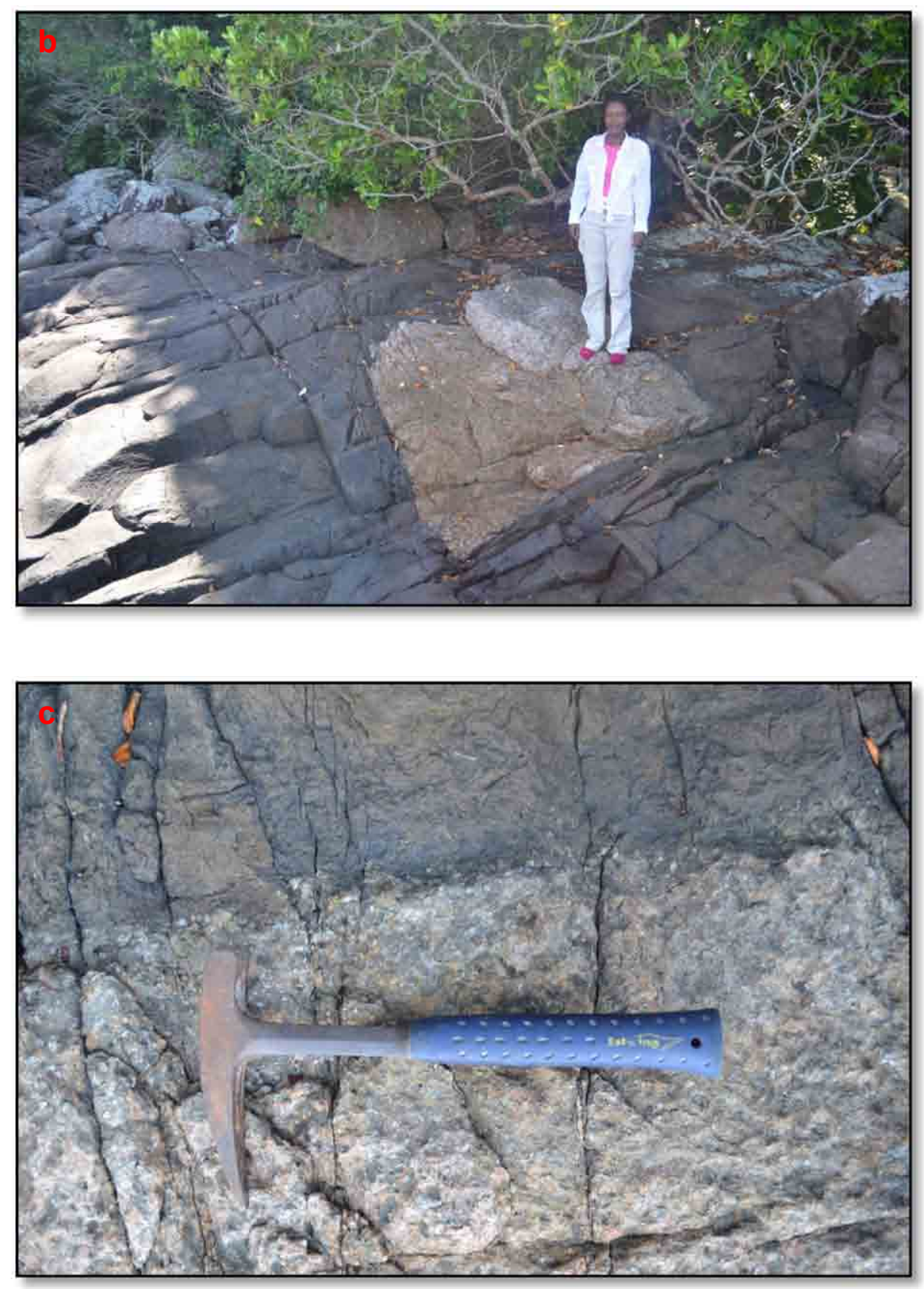

Fig.5.1.7.4 - b) Dique de diabásio com enclaves de charnockito e leucogranitos associados e c) Detalhe do contato entre dique de diabásio com leucogranito. (Fotos: Maria da Glória Motta Garcia). 
5.1.8. Geossítio Xenólitos Mantélicos e Cones de Explosão

Localização (UTM): 0495359/ 7405405 (Figura 5.1.8.1)

Tipo: Ponto

Acesso: O geossítio localiza-se na Praia Vermelha do Centro, a 4,2 km do centro de Ubatuba. O acesso é feito por servidão pública a partir da Rod. Governador Mário Covas (BR101) sentido norte, até a saída para Praia do Tenório pela Av. Franklin de Toledo Piza. O acesso à praia é livre.

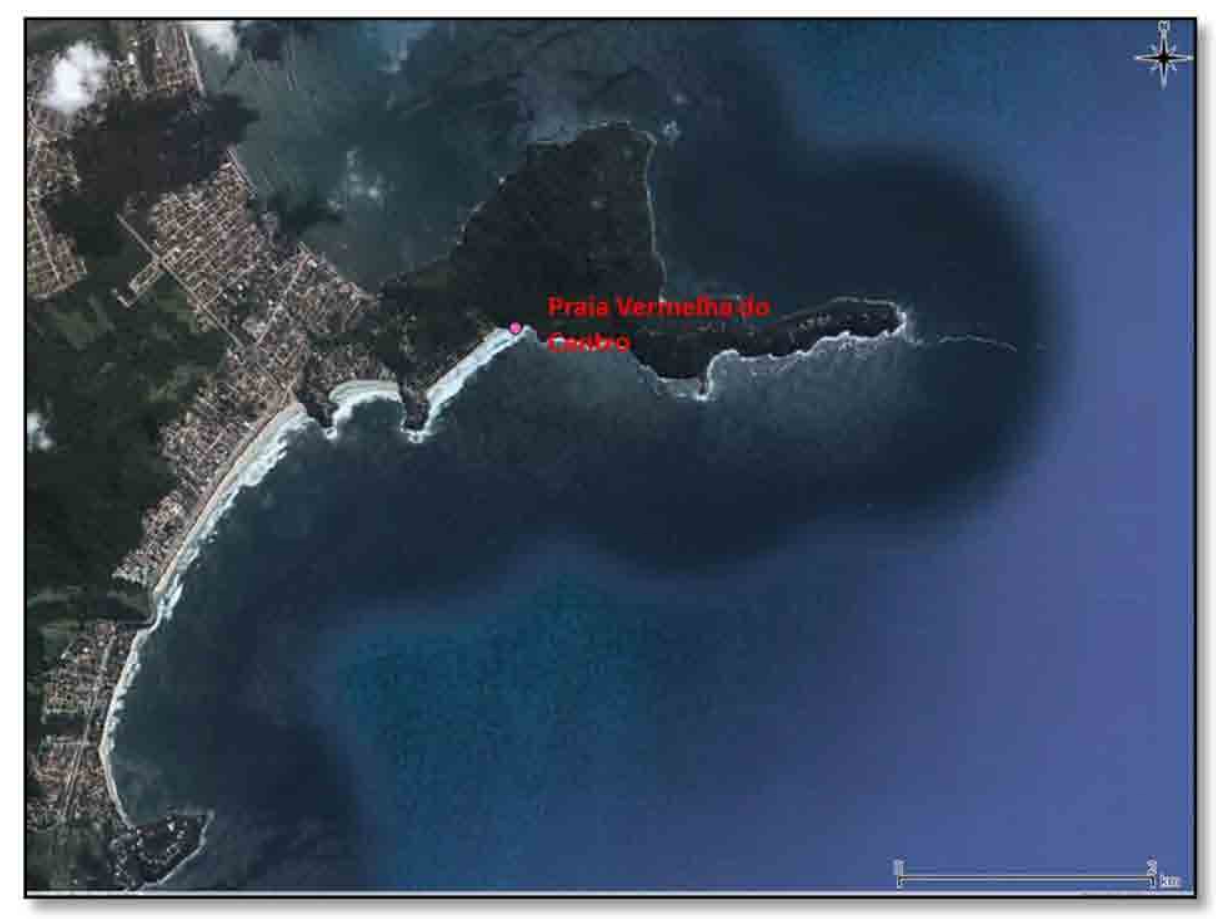

Figura 5.1.8.1 - Mapa de localização do geossítio Xenólitos do manto e cones de explosão. Fonte: Google ${ }^{\circledR}$ in Qgis.

Dimensão: trata-se de um costão rochoso de aproximadamente 150 metros de comprimento.

Unidade no mapa da CPRM (2006): NP3ay2Cub - Charnockito Ubatuba.

Principais litotipos observadas no geossítio: biotita gnaisses graníticos 
Justificativa do valor científico:

Este geossítio ilustra importantes e raros registros do vulcanismo associados à fragmentação do supercontinente Gondwana no Cretáceo Inferior (132 Ma). O afloramento é parte do enxame de diques da Serra do Mar que ocorre nas regiões costeiras entre Santos e o Espírito Santo, cuja principal fase de intrusão ocorreu entre 133-129 Ma (Garda et. al., 1992; Garda, 1995). Associados a esses diques ocorrem duas importantes e raras feições geológicas observadas no litoral do sudeste brasileiro - que justificam a inclusão do local neste inventário: (i) os xenólitos do manto, (ii) feições cônicas interpretadas como cones de explosão.

Elementos principais de interesse:

O afloramento é formado por biotita gnaisses graníticos e charnockitos retrometamórficos. Os gnaisses graníticos são cortados por diques de espessura métrica e composições diversas, orientados nas direções N45, N60 e N75 subverticais, resultantes de erupções fissurais (Figura 5.1.8.2a). De acordo com Garda et. al. (1992), o primeiro grupo litológico constituinte de diques é formado por diques de diabásio denso, em geral de cor cinza-esverdeada, estrutura maciça e textura equigranular média-fina e vesiculação fina e fraca. As rochas deste grupo são compostas de plagioclásio, augitas, pigeonita, minerais como olivina, biotita e ilmenita ocorrem em menores quantidades. Este grupo é caracterizado por erupções fissurais de fluxo tranquilo de magmas pobres em voláteis.

Em um dos diques lamprófiro de cor escura, com cerca de $1 \mathrm{~m}$ de espessura e orientação N60 são encontrados fragmentos de rocha ultramáfica (espinélio Iherzolitos) provenientes do manto e formada a cerca de $100 \mathrm{~km}$ de profundidade. Os xenólitos apresentam dimensão de até $2 \mathrm{~cm}$ com coloração verde e amareloesverdeado e granulação média (ALMEIDA, 2009) (Figura 5.1.8.2b/c). Os xenólitos fornecem importantes informações sobre a constituição do manto terrestre (Figura 5.1.8.2d) e, de acordo com a mesma autora, no Sudeste do Brasil são raras as ocorrências destas feições, sendo conhecidas apenas em Coromandel e Monte Carmelo (MG), Córrego da Cachoeira (MG) e Praia Vermelha (SP).

O segundo grupo litológico de diques é formado por rochas máficas de cor cinza-escura acastanhado, estrutura maciça e textura equigranular, porfirítica e 
apresentam vesículas "grossas" a micro cavernosas. Estas rochas são compostas por uma matriz vítrea com fenocristais de clinopiroxênios cálcicos. Associadas a estas rochas, em diques compostos, ocorrem feições cônicas métricas a submétricas interpretadas como cones de explosão. Estas feições são interpretadas como produtos de erupções explosivas devido à concentração de voláteis durante a colocação do dique (Garda et. al., 1992) (Figura 5.1.8.3a/b/c).

No alforamento também se observam duas familias de fraturas nas direções N55 e N100 que acompanham o padrão regional de um sistema de falhas neoproterozoicas, com direção ENE/EW e aos eventos extensionais durante Cretáceo - Terciário (Capitulo 4). (Figura 5.1.8.4).

Outros tipos de interesse: Didático (nível universitário).

Uso potencial: Científico e didático.

Vulnerabilidade: Natural (baixa). Antrópica média: alunos da área de geociências costumam retirar amostras.

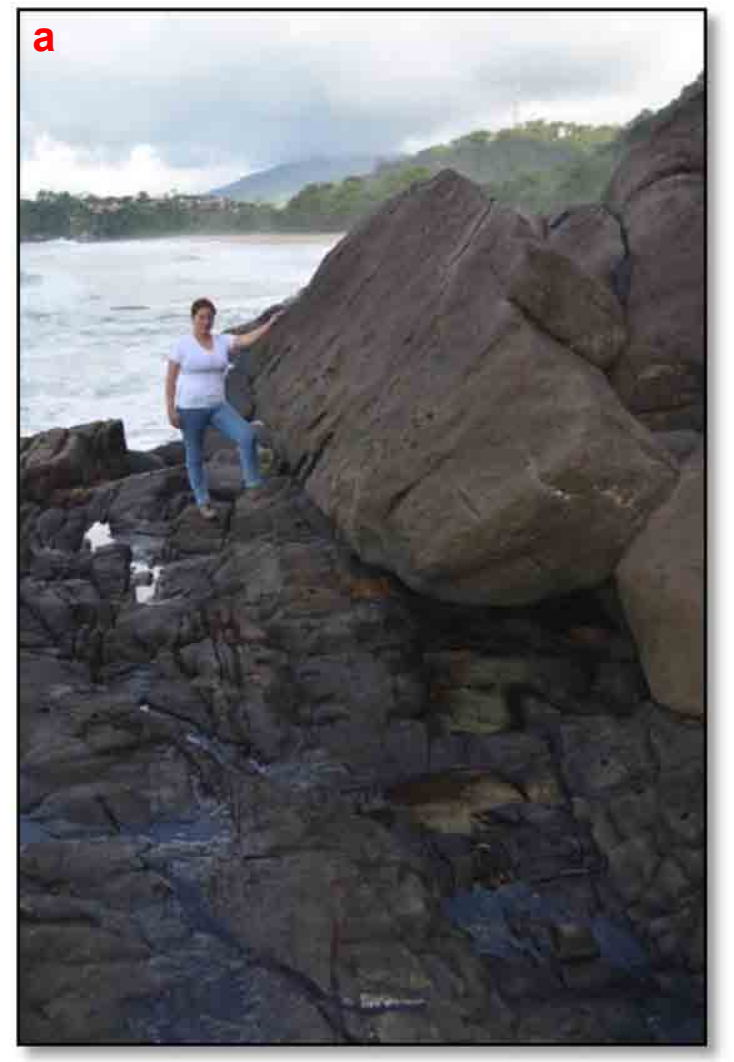

Figura 5.1.8.2 - a) Vista do dique lamprófiro que contém xenólitos. (Foto: Maria da Glória Motta Garcia). 

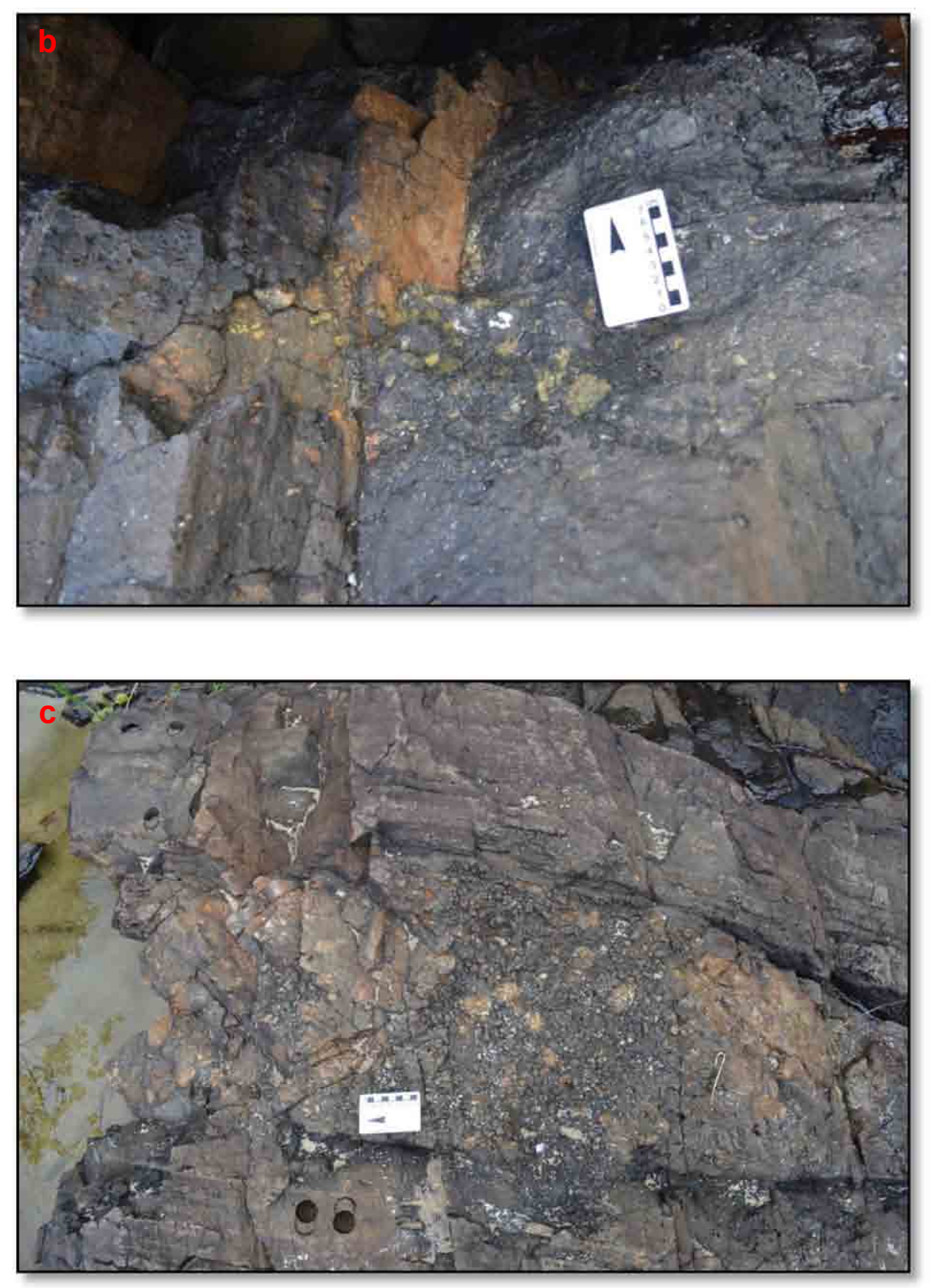

Figura 5.1.8.2 - b) e c) Fragmentos de rochas (espinélio Iherzolitos) que se constituem em xenólitos com alteração marrom-esverdeado em dique lamprófiro na Praia Vermelha do Centro. (Foto: Maria da Glória Motta Garcia) 


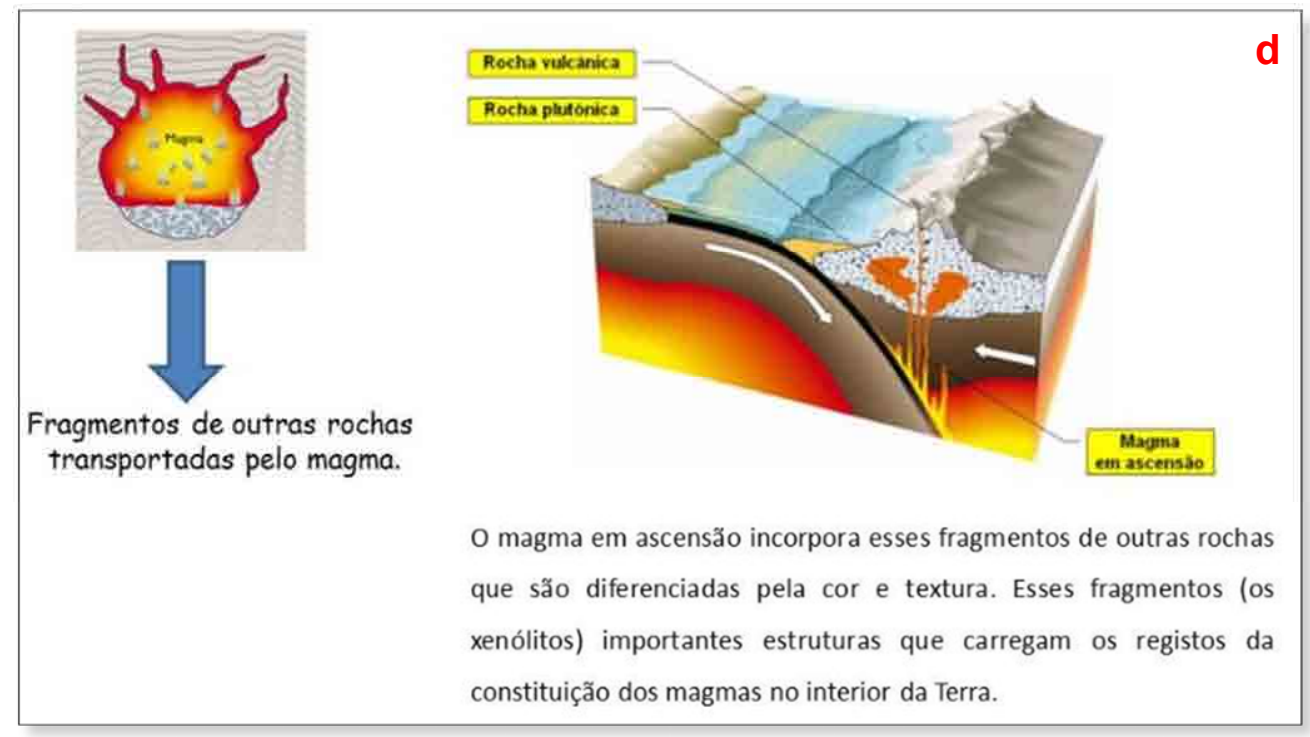

Figura 5.1.8.2 - d) Formação de xenólitos do manto. Fonte: http://www.cientic.com/portal/ (adaptado).

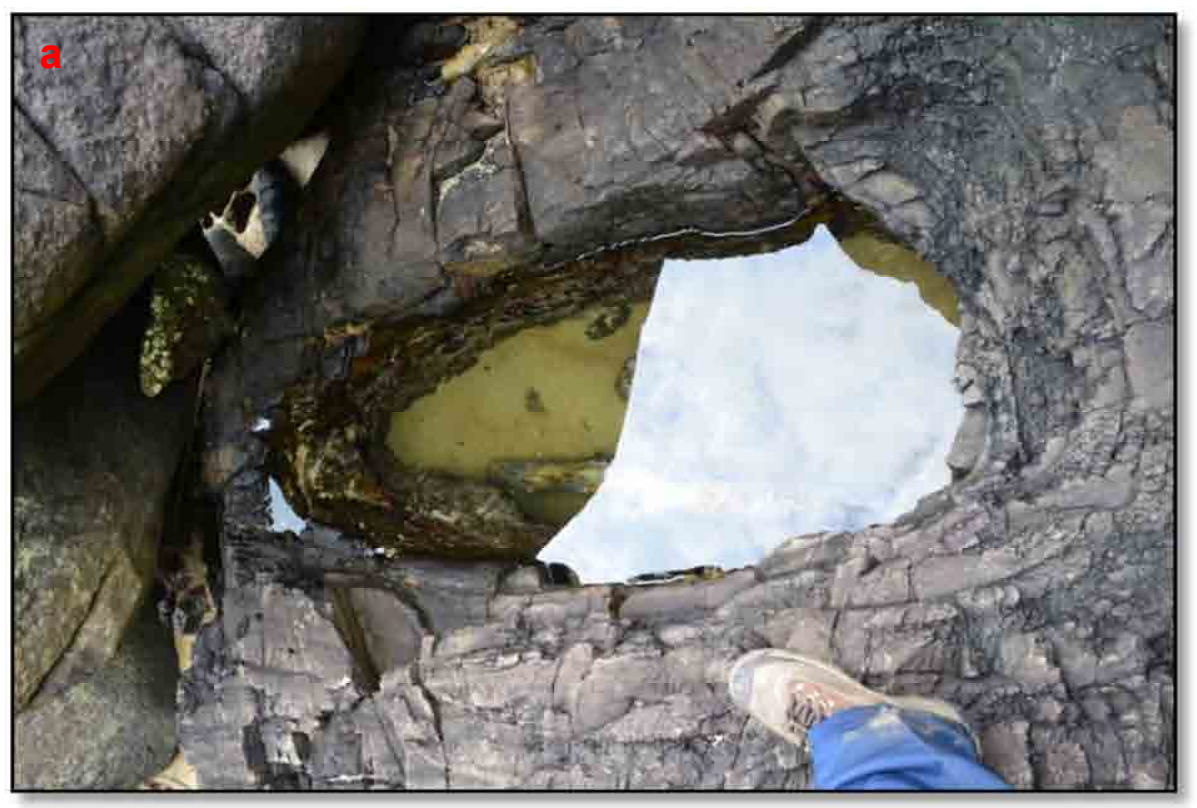

Figura 5.1.8.3 - a) Feição cônica com dimensão submétrica, interpretada como cones de explosão ígneos em diques lamprófiros. (Foto: Maria da Glória Motta Garcia). 


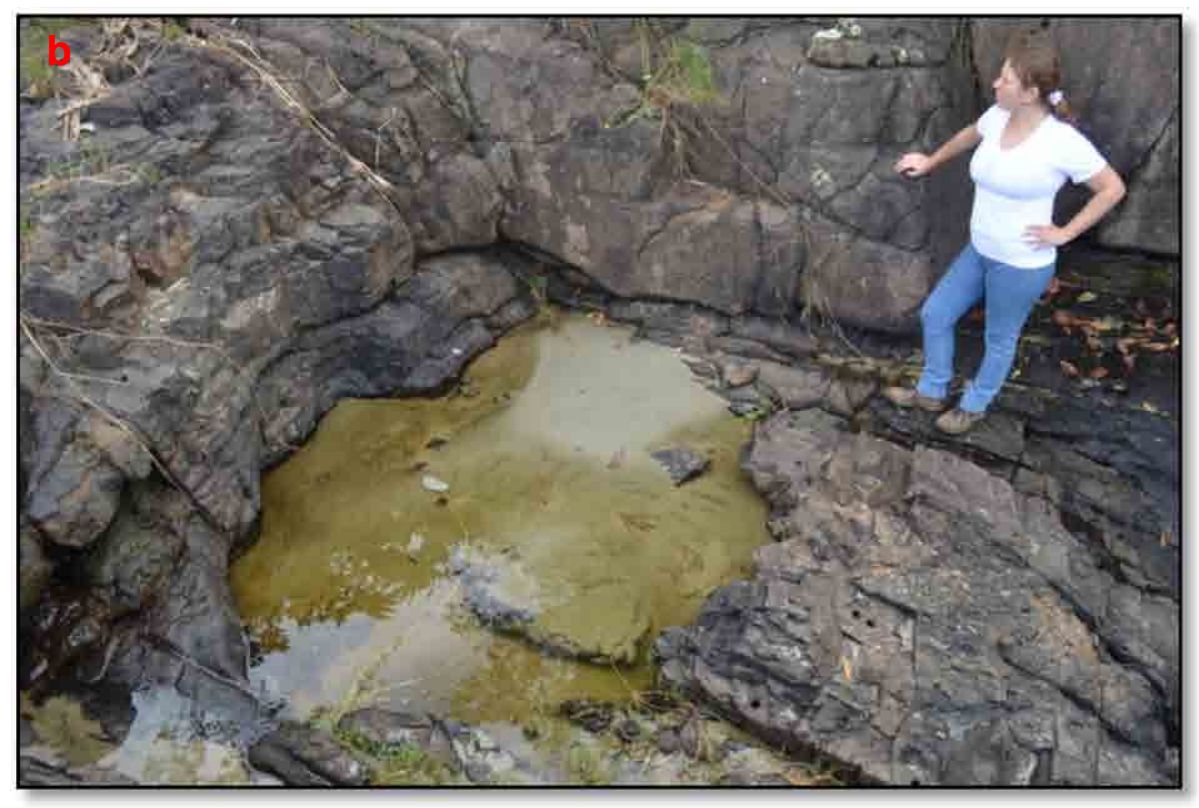

Figura 5.1.8.3 - b) Feição cônica com dimensão métrica, interpretadas como cones de explosão ígneos em diques lamprófiros. (Foto: Maria da Glória Motta Garcia).

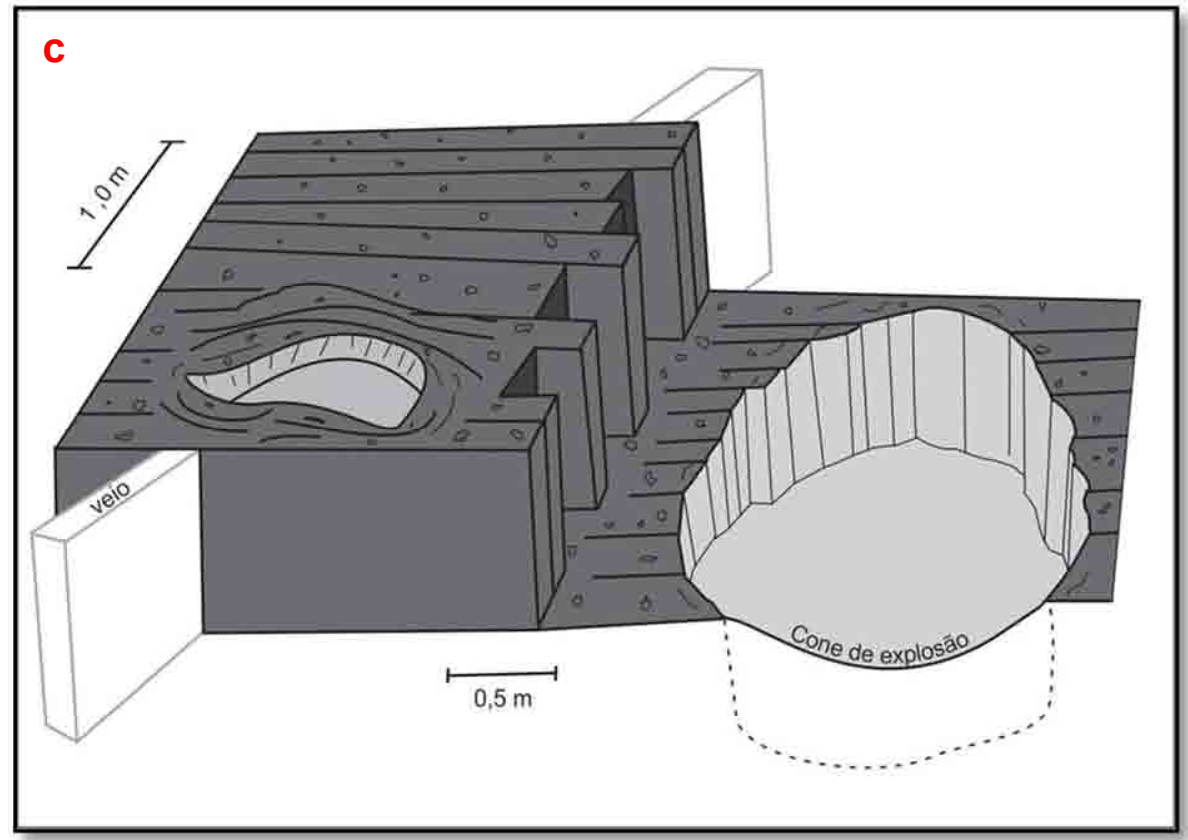

Figura 5.1.8.3 - c) Perfil esquemático dos cones de explosão em dique lamprófiro na Praia Vermelha do Centro. (Autor: Érick Mota). 


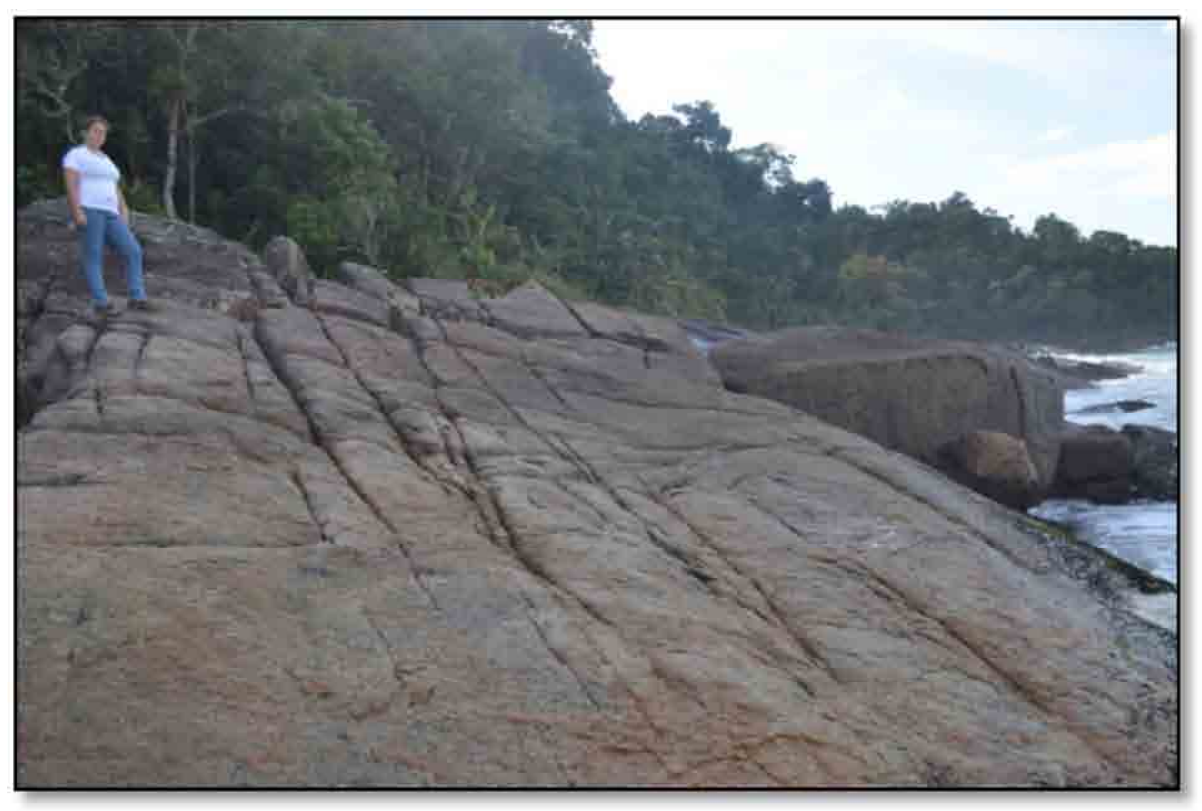

Figura 5.1.8.4 - No afloramento observam-se duas de fraturas nas direções N55 e N100 que acompanham o padrão regional um sistema de falhas neoproterozoicas, com direção ENE/EW. (Foto: Maria da Glória Motta Garcia).

\subsubsection{Geossítio Pico do Corcovado}

Localização (UTM): 0480236/ 7406709 (Figura 5.1.9.1)

Tipo: Ponto

Acesso: O Pico do Corcovado está situado entre os municípios de Ubatuba e Natividade da Serra, a $250 \mathrm{~km}$ de São Paulo. O acesso pode ser feito de dois modos: por meio de uma trilha com extensão de $20 \mathrm{~km}$ a partir do Núcleo Santa Virgínia do Parque Estadual da Serra do Mar e por uma trilha com extensão de 8 km, que se inicia no bairro do Corcovado em Ubatuba, próximo ao km 96 da Rodovia Rio-Santos. Para realização do percurso é necessário o agendamento prévio com o Núcleo Santa Virgínia ou Picinguaba. 


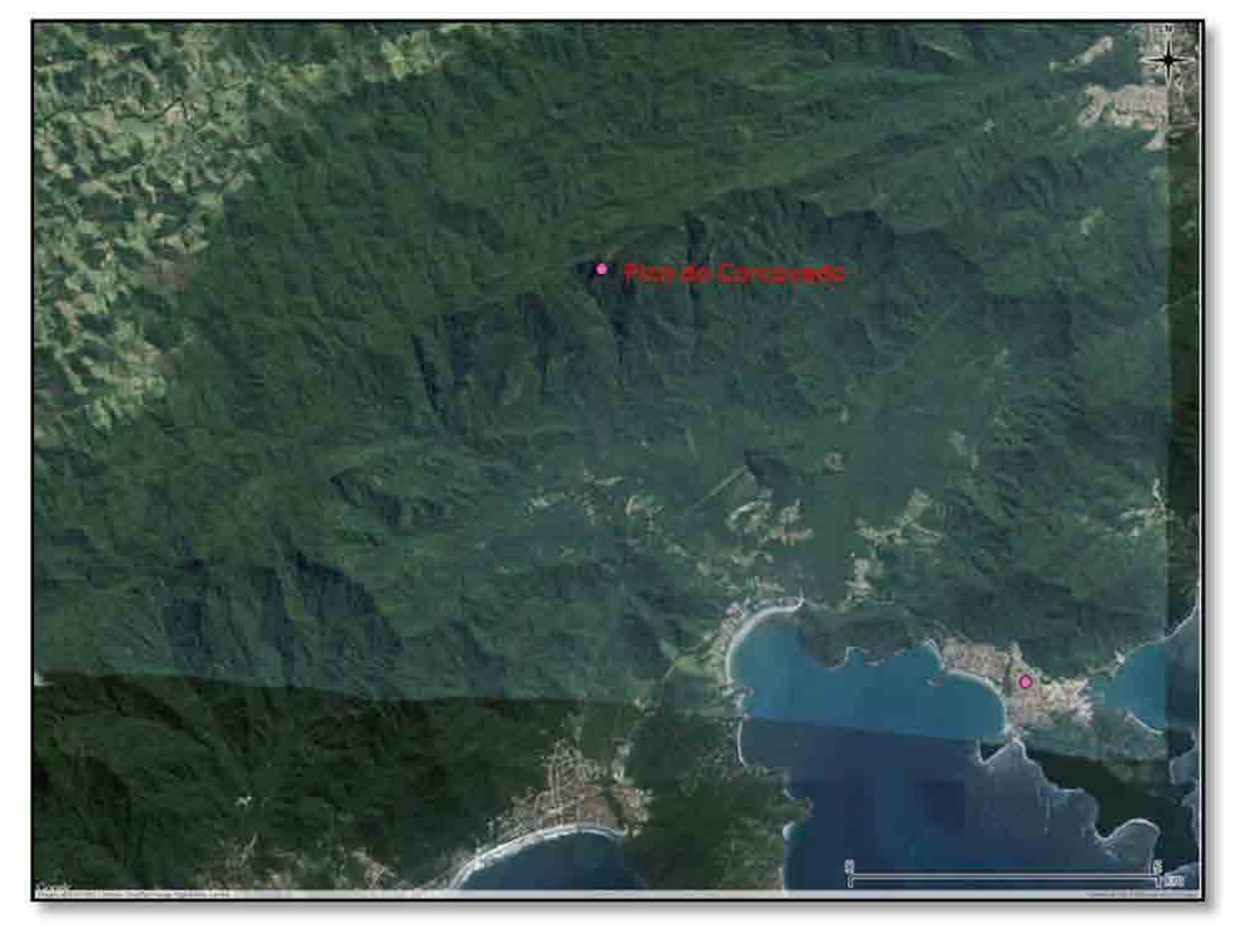

Figura 5.1.9.1 - Mapa de localização do geossítio Pico do Corcovado. Fonte: Google ${ }^{\circledR}$ in Qgis.

Dimensão: No ponto de observação é possível avistar a Serra do Mar e a planície costeira entre os municípios de Caraguatuba, São Sebastião, Ilhabela, Ubatuba até a ponta da Trindade (Paraty - RJ). A vista para o continente nos permite observar a extensão da Serra do Mar para o seu interior (Figura 5.1.9.3).

Unidade no mapa da CPRM (2006): NP3ay1lpp - Granitos foliados calcialcalinos Pico do Papagaio (pp).

Justificativa do valor científico:

O Pico do Corcovado é o ponto culminante da Serra do Mar no estado de São Paulo, com $1.175 \mathrm{~m}$ de altitude. Este geossítio exemplifica importantes eventos tectônicos da fase de fragmentação do Gondwana, no Jurássico-Cretáceo que culminaram com a abertura do Atlântico Sul e resultaram ao longo do tempo nas feições geomorfológicas vistas no litoral de São Paulo.

\section{Elementos principais de interesse:}

O geossítio tem como principais interesses feições geomorfológicas que ocupam o litoral norte de São Paulo: a Serra do Mar e a planície costeira. 
A reativação mesozoica de antigas descontinuidades neoproterozoicas em pulsos descontínuos é caracterizada por eventos extensionais, que perduraram do Cretáceo ao Terciário. Estes eventos tectônicos resultaram no processo inicial da formação do Rift Continental do Sudeste Brasileiro (RCSB), definido Riccomini (1989) como uma depressão alongada com aproximadamente $900 \mathrm{~km}$ de comprimento que compõe um sistema de bacias trafogênicas que foram instaladas no domínio da Faixa Ribeira, de idade neoproterozoica durante o Cenozóico (55 $11 \mathrm{Ma}$ ) (Capítulo 4). Além disso, esses eventos resultaram na elevação da borda leste do continente Sul-Americano na porção Sudeste do Brasil. (ALMEIDA \& CARNEIRO, 2008; HIRUMA et. al., 2010, PIEKARZ s/d). Durante o Cretáceo Superior $(\sim 80 \mathrm{Ma})$ a região constituiu-se em superfície de aplainamento pela ação dos processos erosivos e intemperismo.

A Serra do Mar originou-se a partir de eventos tectônicos verticais iniciados no Paleoceno $(\sim 65 \mathrm{Ma})$, a reativação de uma falha normal, a Falha de Santos, resultou no soerguimento da borda ocidental e abatimento da porção oriental formando uma porto-serra (ALMEIDA \& CARNEIRO, 2008) (Figura 5.1.9.2).

Do Paleoceno aos dias atuais a ação do intemperismo e movimentos de massa recuaram as escarpas da serra dezenas de quilômetros da sua posição original, processos que culminaram na formação das ilhas e baixadas próximo à costa (ALMEIDA \& CARNEIRO, 1998). Contudo, as escarpas da Serra do Mar, em alguns trechos do litoral, se aproximam bastante da costa formando bacias de drenagem bem restritas e formando baías e enseadas e planícies costeiras bastantes estreitas e descontínuas à medida que se aproxima do Rio de Janeiro. Neste sentido, o Pico do Corcovado constitui-se um excelente ponto de observação destas feições geomorfológicas, sendo possível de observar as escarpas da Serra do Mar, baías, enseadas, planícies costeiras e ilhas ao longo da costa. A vista para o interior do continente, observa-se a Serra do Mar e da Mantiqueira separadas pelo RCSB. (Figura 5.1.9. 4a/b/c) (SOUZA, 2012; TESSLER et. al., 2002).

Outros tipos de interesse: Turístico.

Uso potencial: Científico e turístico.

Vulnerabilidade: Natural baixa. 


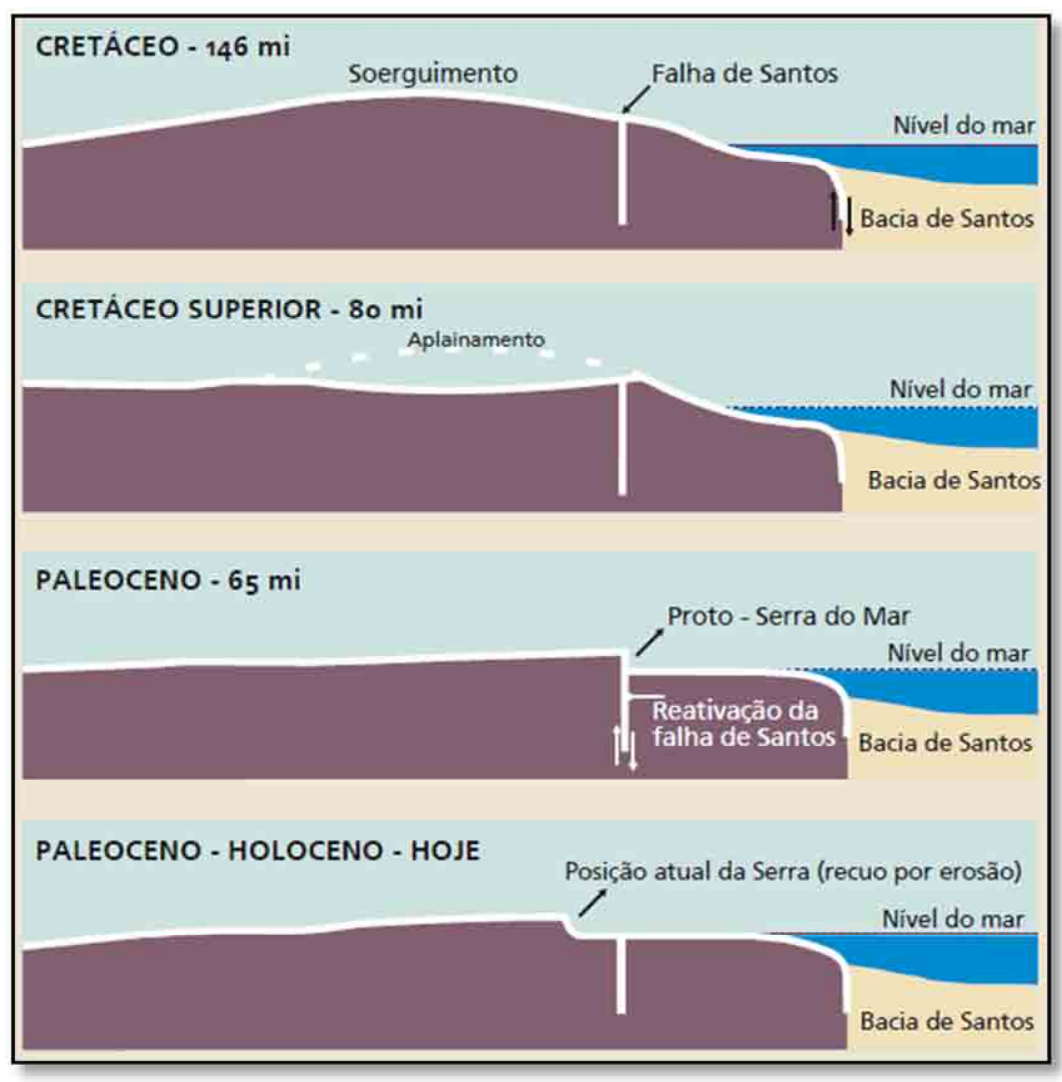

Figura 5.1.9.2 - Evolução geológica da Serra do Mar. Fonte: SANTOS, 2004.

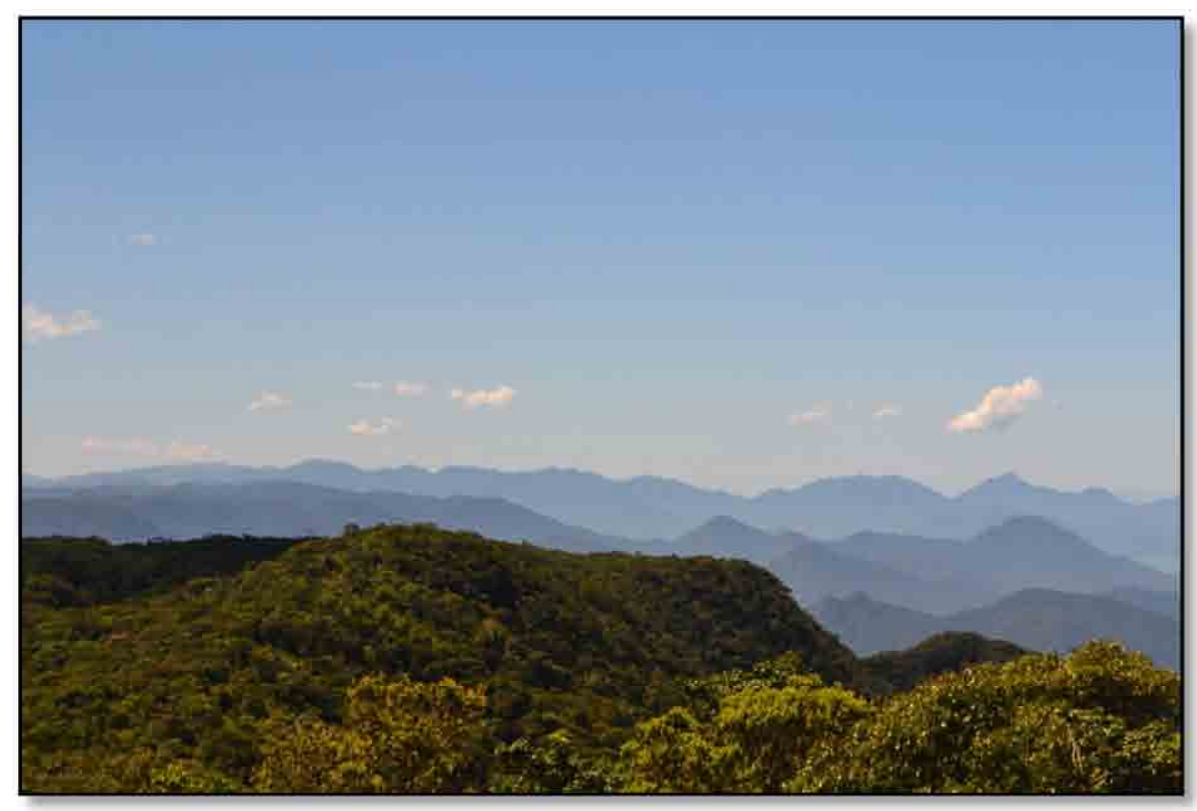

Figura 5.1.9.3 - Vista da Serra do Mar para o interior do continente onde se observa ao fundo a Serra da Mantiqueira, cuja formação está associada a Serra do Mar. Entre as escarpas das duas serras localiza-se o Rift Continental do Sudeste Brasileiro (RCSB). (Foto: Maria da Glória Motta Garcia). 


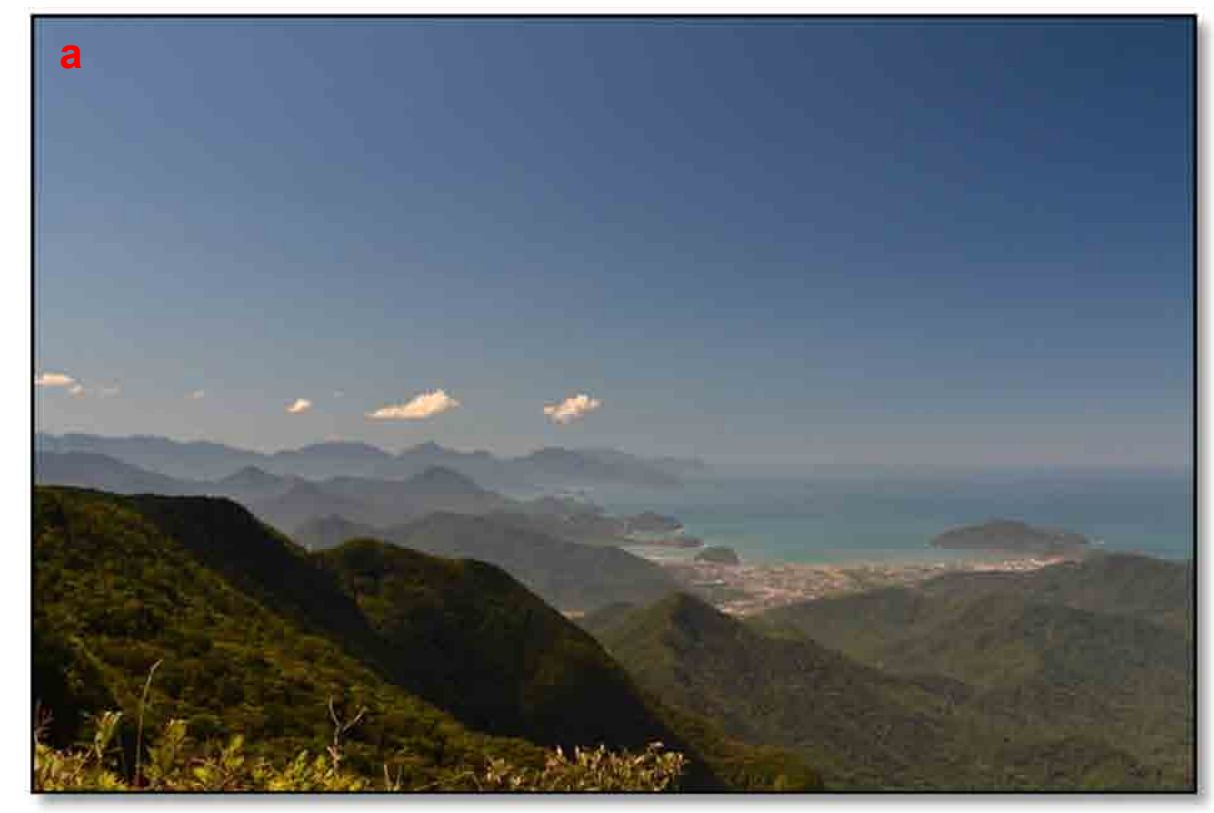

Figura 5.1.9.4 - a) Vista das escarpas da Serra do Mar e da planície costeira ao longo da costa de Ubatuba até a ponta de Trindade ao fundo. (Foto: Érick Mota).

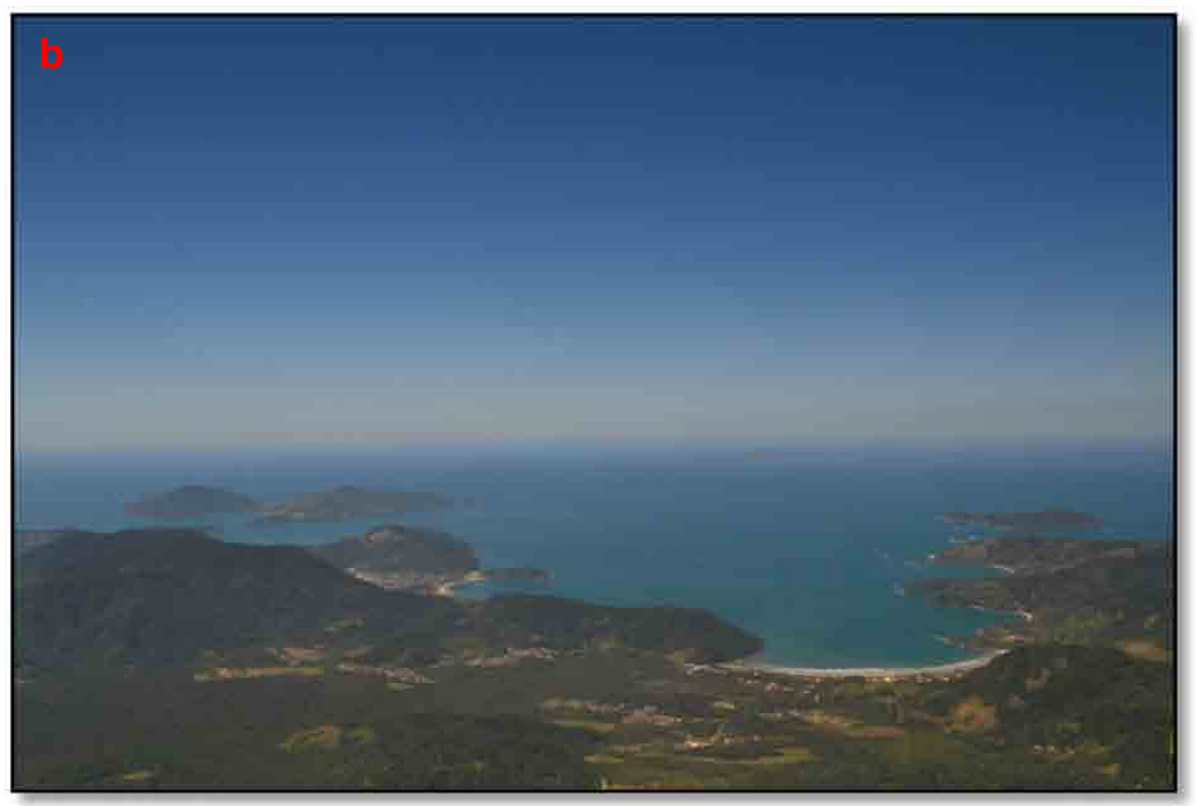

Figura 5.1.9.4 - b) Vista da planície costeira de Ubatuba, em que se pode notar a linha de costa mais recortada, formando praias de enseadas e praias de bolso, feições geomorfológicas típicas do litoral norte de São Paulo. À esquerda observa-se a llha Anchieta e a direita o llhote de Dentro. (Foto: Érick Mota). 


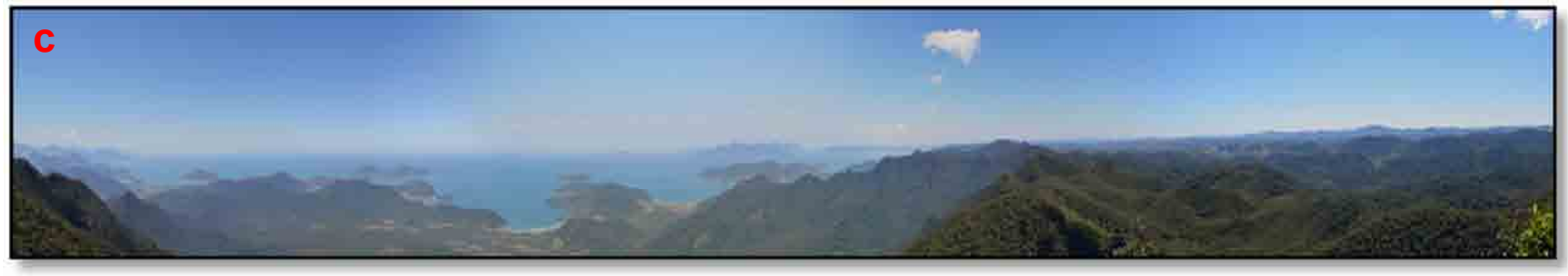

Figura 5.1. 9.4 - c) Vista panorâmica do Pico do Corcovado. (Foto: Maria da Glória Motta Garcia).

\subsubsection{Geossítio Pedreira Itamambuca}

Localização (UTM): 0500694/ 7412562 (Figura 5.1.10.1).

\section{Tipo: Ponto}

Acesso: O geossítio está localizado no costão esquerdo da Praia de Itamambuca, a $13 \mathrm{~km}$ a norte do centro de Ubatuba. O acesso à praia é feito por via secundária, a partir do km 36 da Rodovia Rio-Santos (BR101), sentido Rio de Janeiro.

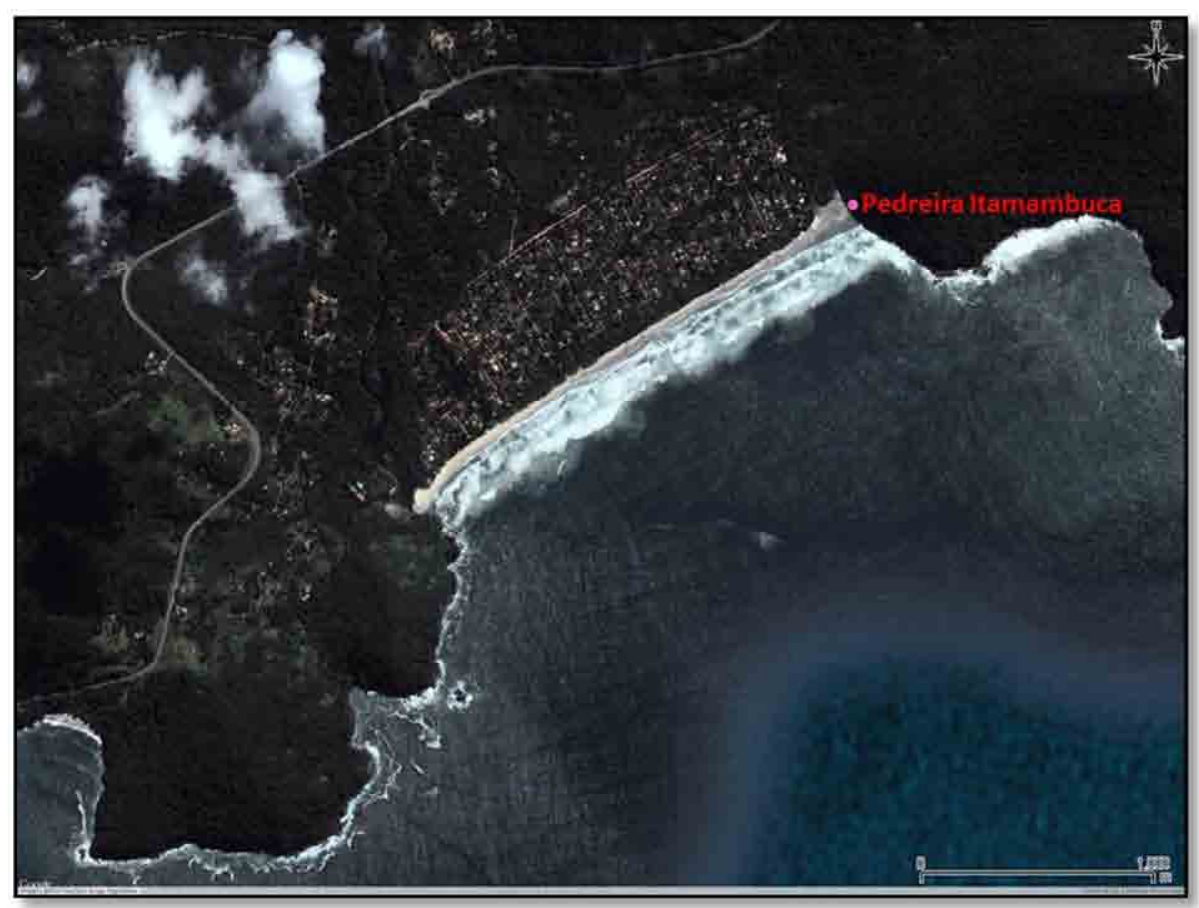

Figura 5.1.10.1 - Mapa de localização do geossítio Pedreira Itamambuca. Fonte: Google $®$ in Qgis. 
Dimensão: trata-se de um costão rochoso de aproximadamente 50 metros e grandes blocos de charnockito de aproximadamente $2 \mathrm{~m}^{2}$ de uma antiga pedreira no lado esquerdo da Praia de Itamambuca.

Unidade no mapa da CPRM (2006): NP3ay2Cub - Charnockito Ubatuba.

Principais litotipos observadas no geossítio: Charnockito Ubatuba.

Justificativa do valor científico:

As rochas charnockíticas representam importantes eventos da fase de aglutinação do Supercontinente durante o Ciclo Brasiliano II (HASUI, 2010) (como abordado em 5.1.1). A comercialização destas rochas, principalmente durante a década de 80, contribuiu fortemente para o desenvolvimento social e econômico da região de Ubatuba. Portanto, este geossítio foi incluído neste inventário com o principal interesse o regate da história de extração do charnockito, também conhecido comercialmente como "Granito Verde Ubatuba", uma importante rocha ornamental da região.

Elementos principais de interesse:

A história da mineração no Brasil, de acordo com VARGAS et. al. (2001) se inicia no período colonial, com a extração de granitos e gnaisses para a construção civil. A utilização de mármore para uso ornamentais teve inicio no século $X X$, no Município de Mar de Espanha em Minas Gerais. Entre 1908 e 1938, a mineração no Brasil, chegou a suprir $73 \%$ do consumo nacional. Assim, as lojas que surgiram durante este período passaram a ser chamadas de "marmorarias". Na década de 50 com o avanço tecnológico e desenvolvimento de novas técnicas de extração os "granitos" se tornaram economicamente as mais importantes rochas ornamentais do Brasil.

As rochas ornamentais comercialmente são dividas em três grupos: (i) granitos (ii) mármores e (iii) ardósias. Os granitos representam comercialmente as rochas ígneas e metamórficas, compostas principalmente por minerais silicáticos, félsicos, com dureza entre 6 e 7 na escala de Mohs, como quartzo, feldspato alcalino e plagioclásio. Os "granitos" possuem a propriedade de alta dureza, por tal motivo requerem técnicas específicas para serem explotados e são consideradas 127 
rochas de ornamentais de alta qualidade (LARIZZATTI \& MENEZES, 2005; VARGAS et. al., 2001). Este grupo comercialmente inclui: granito, quartzo monzonito, granodiorito, quartzo diorito, gabro, álcali sienito, nefelina sienito, gnaisse facoidal, ortognaisse, paragnaisse, charnockito, dentre outros.

BRANCO (2008 p.70) define o charnockito como "variação de granito com hiperstênio, usada como pedra ornamental. Emprega-se muito, no Brasil, como o charnockito conhecido comercialmente Verde Ubatuba. O nome é homenagem a Job Charnock, fundador de Calcutá, Índia, cujo túmulo a rocha foi descoberta". Durante a década de 80 , constituiu-se uma das mais importantes rochas ornamentais do Brasil (Figura 5.1.10.4). Na região de Ubatuba foram extraídos grandes volumes de rochas, que foram exportados principalmente para o Japão e Itália. Reconhecem-se pelo menos 160 pontos de antigas extrações de charnockitos, dentre eles a Pedreira Itamambuca, que representa uma das maiores áreas de extração da rocha (Figura 5.1.10.2a/b/c/d). Em 1977, com a criação do Parque Estadual da Serra do Mar, a extração da rocha foi interrompida. Na ocasião foram gerados grandes problemas econômicos para a população local, que praticamente tinham sua principal fonte de geração de renda relacionada à exploração da rocha (Sr. Eustáquio, um morador local que trabalhou durante 40 anos na extração do charnockito, com. oral). Atualmente a exploração da rocha está proibida, mesmo em locais fora da área do PESM.

No geossítio podemos observar a rocha in situ e grandes blocos com marcas que explosivos remanescentes da extração. Também há parte de uma antiga construção (Figura 5.1.10.3a/b/c/d).

Outros tipos de interesse: Didático (nível universitário) e histórico-cultural.

Uso potencial: Científico, turístico e didático.

Vulnerabilidade: Natural (baixa). 

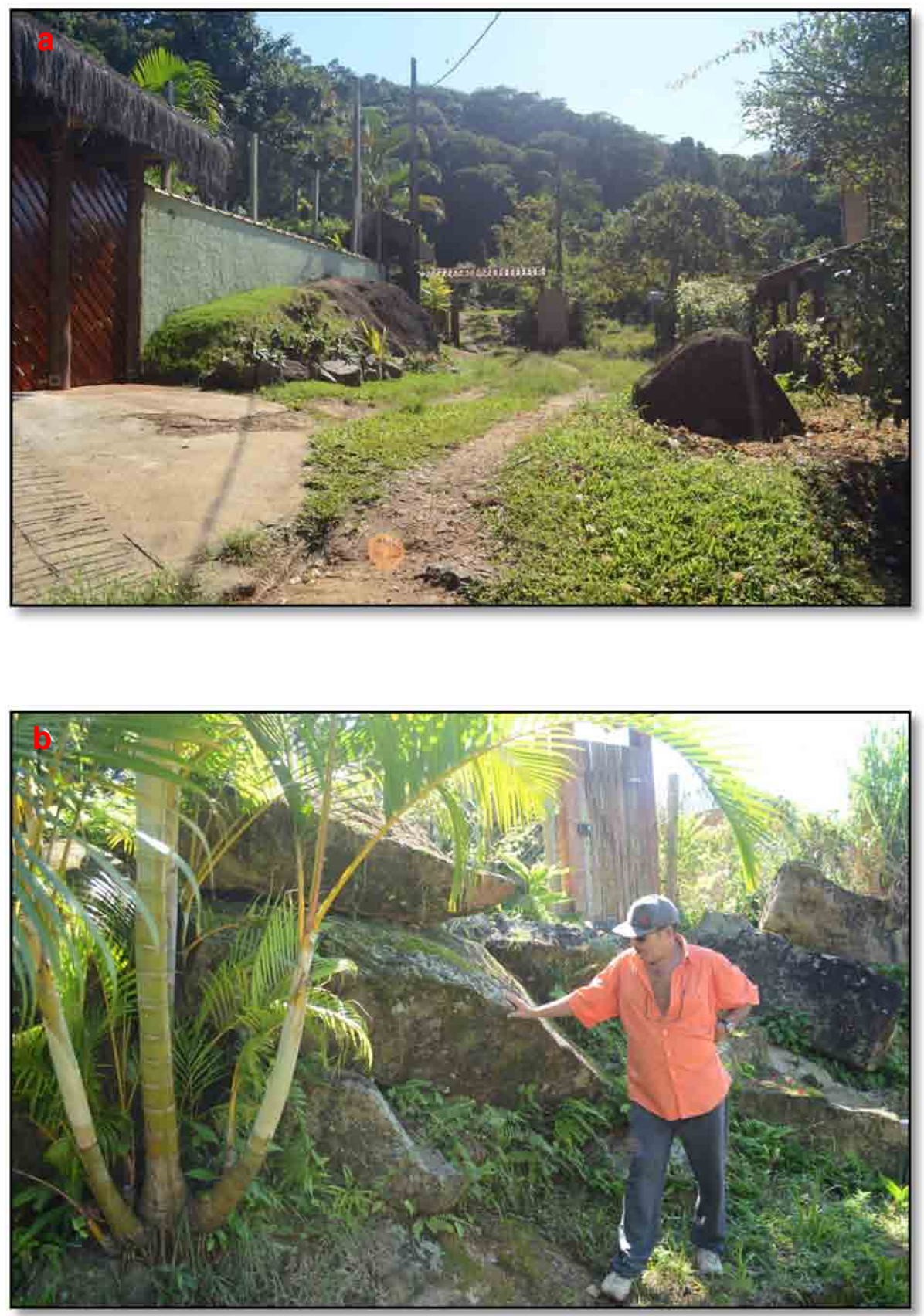

Figura 5.1.10.2 - a), b) Pontos de antigas extrações de charnockito no bairro Sertãozinho do Prumirim. (Fotos: Maria da Glória Motta Garcia). 

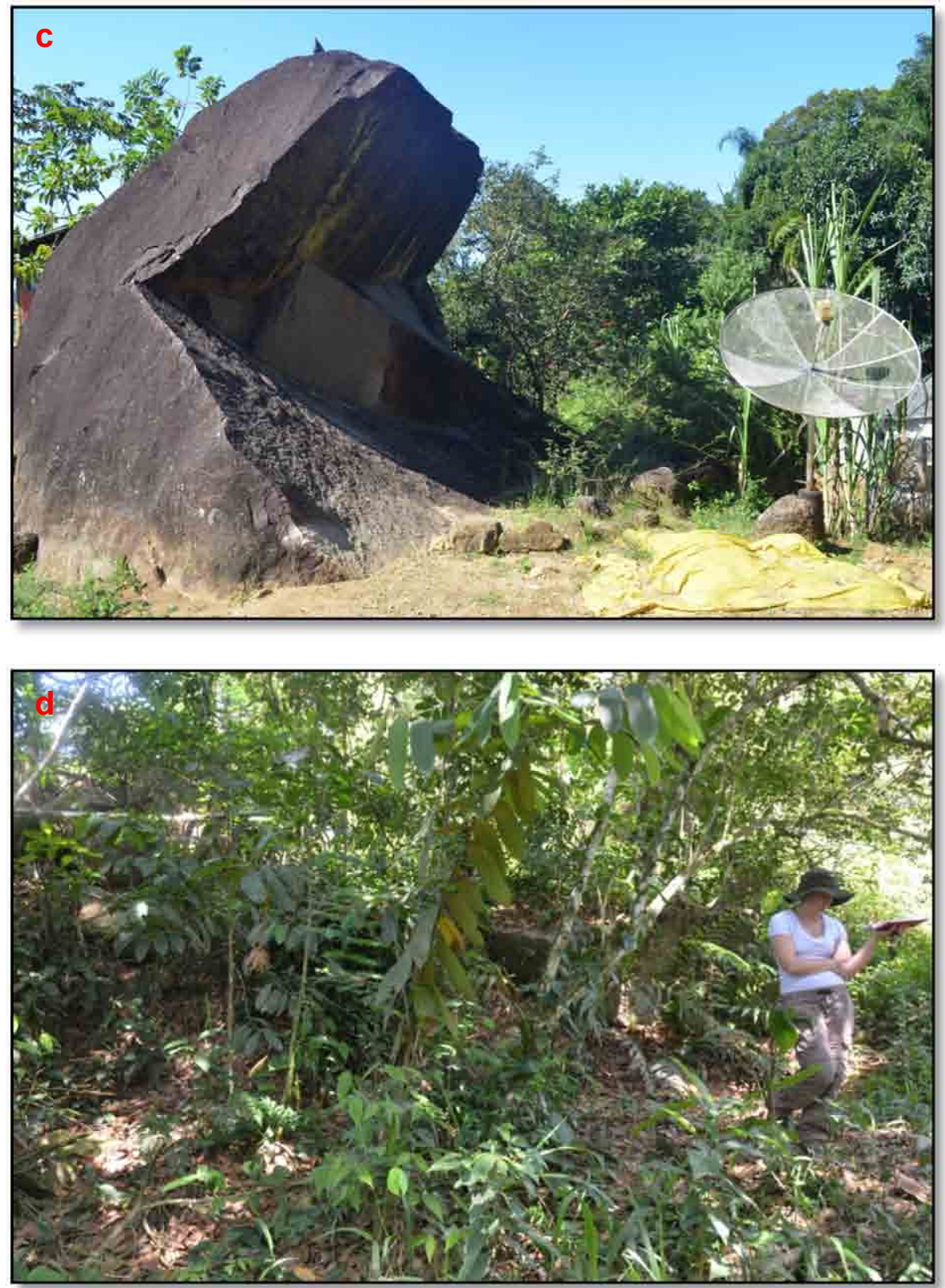

Figura 5.1.10.2 - c) Local de antiga extração de charnockito no bairro Sertãozinho do Prumirim, d) antiga extração de charnockito próximo à praia da Mãe Maria. (Fotos: Maria da Glória Motta Garcia) 

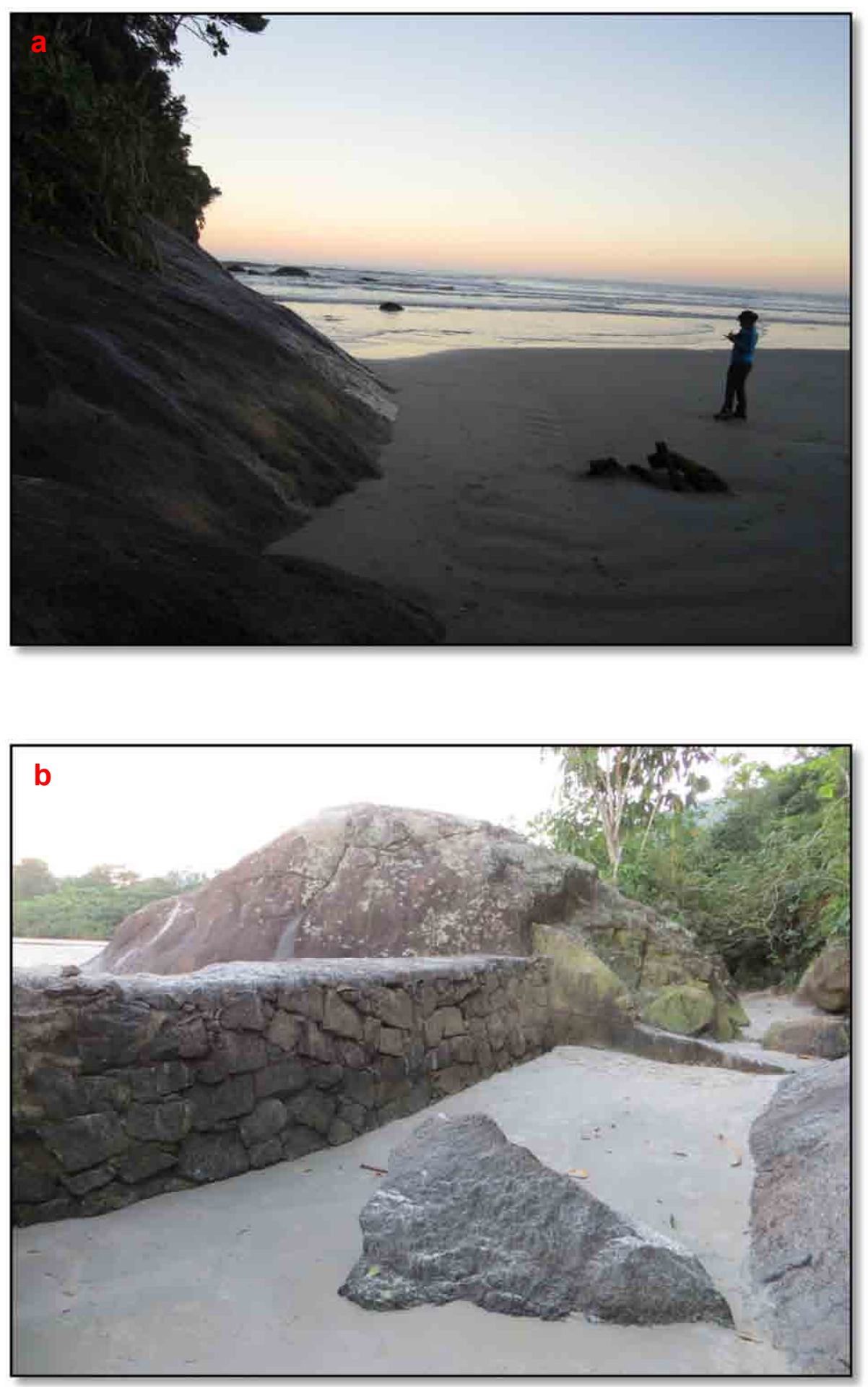

Figura 5.1.10.3 - a) Vista do costão rochoso e Praia de Itamambuca; b) Vista da antiga pedreira Itamambuca e restos de uma antiga construção. (Foto: Fernanda Reverte). 

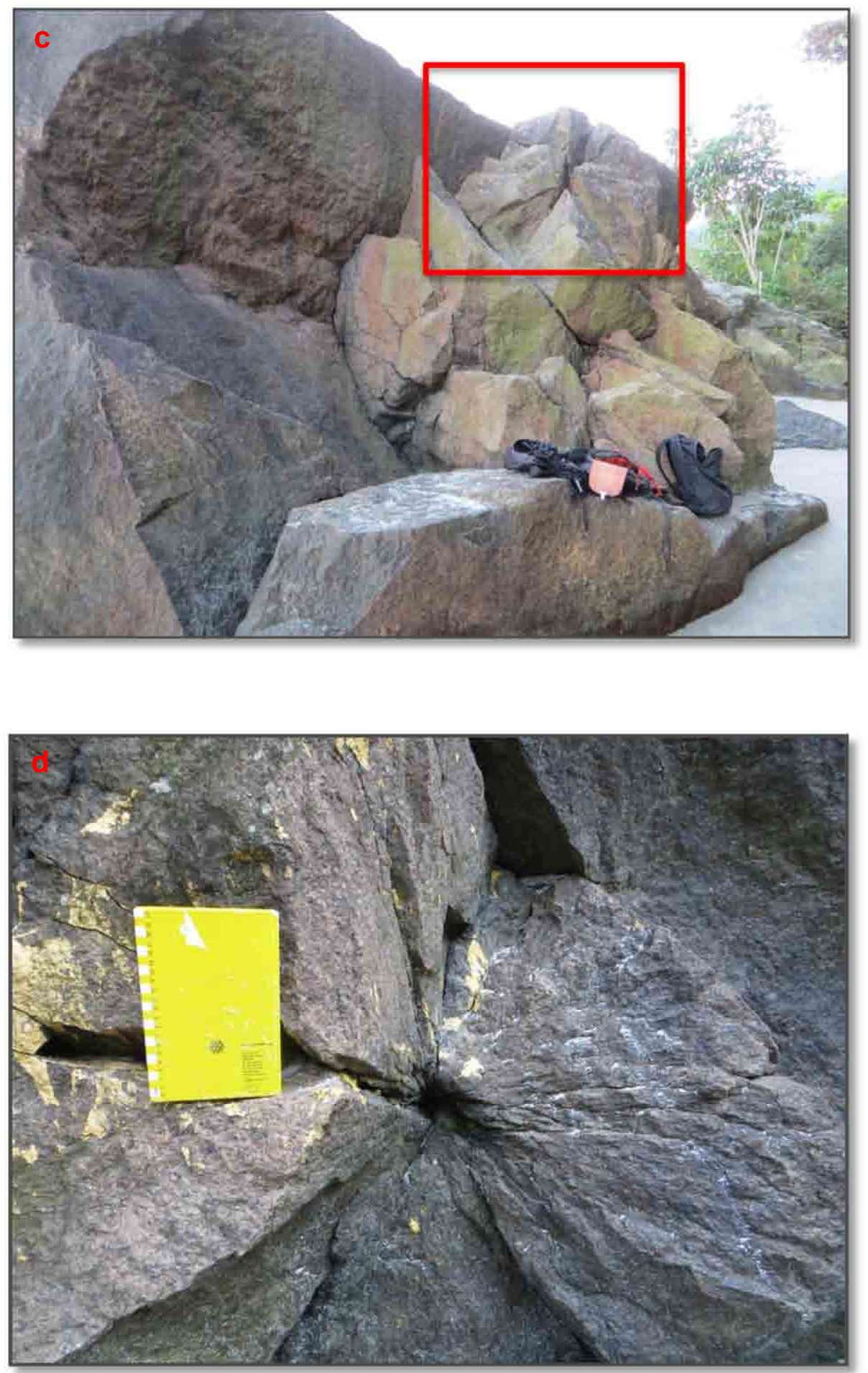

Figura 5.1.10.3 - c) e d) Afloramento de charnockito. Em (d) observa-se em detalhe a foto (c) onde há marcas de explosivos na rocha. (Fotos: Fernanda Reverte). 


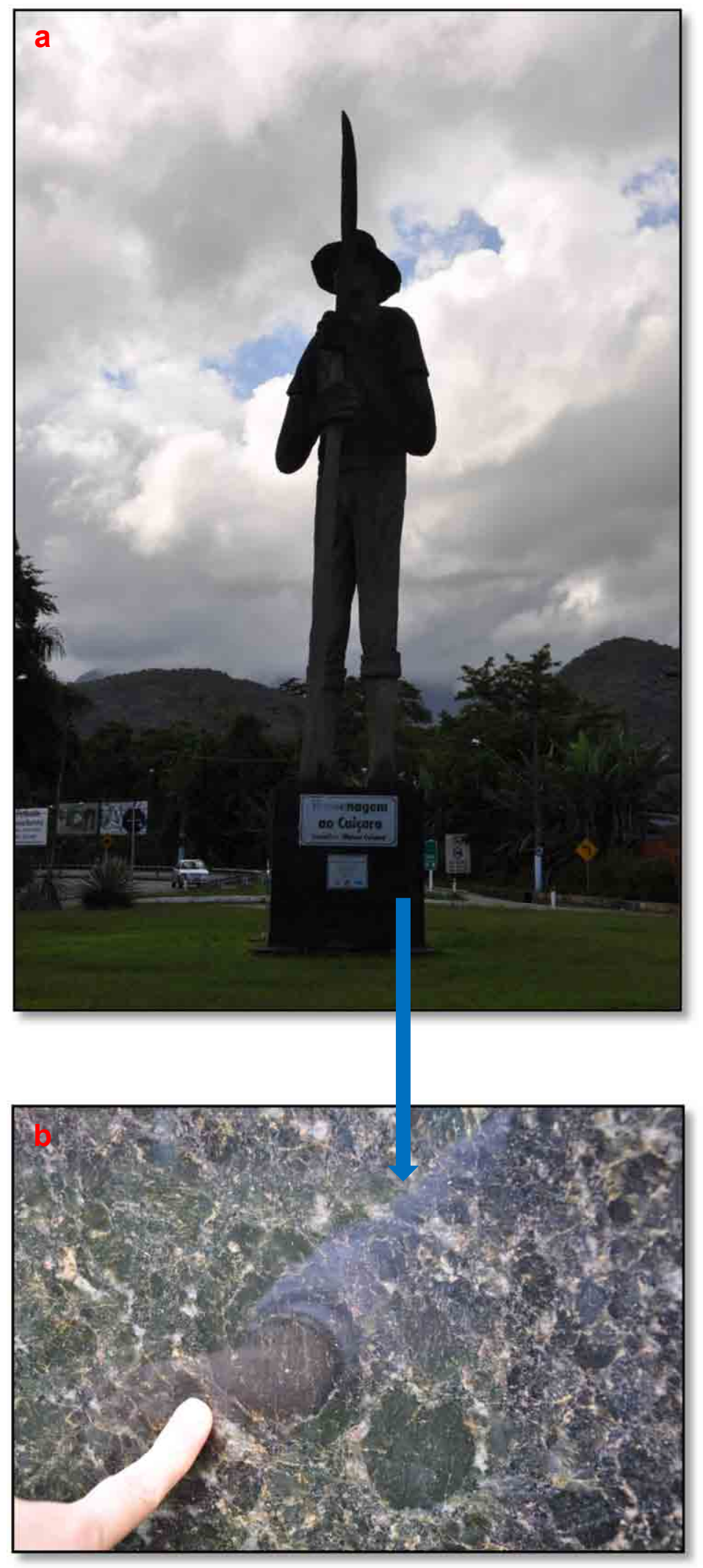

Figura 5.1.10.4 - a) e b) Uso ornamental do charnockito Ubatuba como revestimento do monumento aos pescadores de Ubatuba na entrada da Cidade. (Fotos: Eliane Del Lama). 


\section{QUANTIFICAÇÃO DOS GEOSSÍTIOS INVENTARIADOS}

A quantificação de relevância consiste na seriação dos geossítios. Esta etapa da estratégia de geoconservação (Capítulo 2) pode ser feita de maneira numérica a partir da integração de critérios dos geossítios que levam em conta as suas características intrínsecas, o uso potencial e o nível de proteção necessário para cada um deles (BRILHA, 2005). O uso da quantificação numérica de acordo com o mesmo autor permite a diminuição da subjetividade inerente ao processo de quantificação e o estabelecimento da prioridade nas ações de geoconservação, ou seja, a indicação dos geossítios que devem ser submetidos prioritariamente às etapas seguintes das estratégias de geoconservação. Pereira $\left(2006^{19}\right)$ apud Lima (2008) considera a quantificação numérica um forte aliado à etapa de inventário, pois permite a comparação entre os geossítios que o compõem.

Nas últimas décadas foram apresentados diversos métodos de quantificação de geossítios. De modo geral, Medina (2012) ressalta que estas propostas aparecem como resultados de análises, testes e combinações de métodos anteriores e variam de abordagens mais simples, que reúnem critérios de avaliação do potencial turístico e/ou científicos, a abordagens mais complexas que avaliam tanto o potencial cientifico e turístico, quanto os aspectos de uso/gestão e necessidade de proteção. Neste sentido, no presente trabalho foram avaliados diferentes métodos de quantificação de relevância de geossítios.

Inicialmente, optou-se pelo uso do método desenvolvido por Brilha (2005) por se tratar de um método aplicável em diferentes áreas e constituir o método "base" para a proposta da CPRM - o aplicativo GEOSSIT. Optou-se pelo teste do aplicativo GEOSSIT, por se tratar de uma iniciativa pioneira que prevê o cadastramento, quantificação e valoração de geossítios em nível nacional. Entretanto, extrapolando a proposta inicial, tendo em vista o potencial turístico da área enfocada, optou-se também pelo uso do método proposto por Pereira (2010) para a quantificação do geossítios da Chapada Diamantina - BA, que parte de propostas preexistentes, porém, destaca o valor turístico dos geossítios como uma categoria específica. Esta categoria reúne critérios específicos referentes à utilização turística dos locais.

19 PEREIRA, P. J. S. Patrimônio Geomorfológico: conceptualização, avaliação e divulgação. Aplicação ao Parque Natural de Montesinho. 2006. 370 pp. Tese de Doutoramento em Ciências. Escola de Ciências da Universidade do Minho. 2006. 
Cabe ressaltar que, os critérios adotados foram consequentemente adaptados para a região de estudo.

6.1. Metodologias adotadas para quantificação dos geossítios inventariados

6.1.1. Método de Brilha (2005)

Brilha (2005) apresenta uma proposta de quantificação do valor de relevância de cada geossítio baseada no trabalho de Uceda (2000). Esta proposta reúne 22 parâmetros (Tabela 6.1.1.1) que definem (A) o valor intrínseco, (B) o uso potencial e (C) a necessidade de proteção de cada geossítio. Este método objetiva a seriação dos geossítios, estabelecendo as prioridades de proteção para cada um deles. Assim, os geossítios que apresentarem o maior valor de relevância (Q) apresentam maior urgência em serem submetidos às estratégias de geoconservação (BRILHA, 2005).

\begin{tabular}{|c|c|c|}
\hline A - Características Intrínsecas & B - Uso Potencial & C - Necessidade de Proteção \\
\hline A1 - Abundância/Raridade & $\begin{array}{l}\text { B1 - Possibilidade de realizar as } \\
\text { atividades propostas }\end{array}$ & C1 - Ameaças atuais ou potenciais \\
\hline A2 - Extensão & B2 - Condições de Observação & C2 - Situação atual \\
\hline A3 - Grau de conhecimento científico & $\begin{array}{l}\text { B3 - Possibilidade de coleta de } \\
\text { materiais }\end{array}$ & $\begin{array}{l}\text { C3 - Interesse para exploração } \\
\text { mineral }\end{array}$ \\
\hline $\begin{array}{l}\text { A4 - Representatividade na ilustração de } \\
\text { modelos, processos ou unidades } \\
\text { geológicas (local tipo) }\end{array}$ & B4 - Acessibilidade & C4 - Valor dos terrenos \\
\hline $\begin{array}{l}\text { A5 - Diversidade de elementos de } \\
\text { interesse }\end{array}$ & B5 - Proximidade de povoações & C5 - Regime de propriedade \\
\hline \multirow{2}{*}{ A6 - Localidade-tipo } & \multirow{2}{*}{$\begin{array}{l}\text { B6 - População a ser beneficiada } \\
\text { com a utilização/divulgação do } \\
\text { geossítio }\end{array}$} & C6 - Fragilidade \\
\hline & & \\
\hline A7 - Associação com elementos culturais & B7 - Condições socioeconômicas & \\
\hline A8 - Associação com elementos naturais & & \\
\hline A9 - Estado de conservação & & \\
\hline
\end{tabular}

Tabela 6.1.1.1. Critérios de quantificação de relevância dos geossítio. Adaptada de Brilha (2005).

Os geossítios que apresentarem as pontuações apresentadas na Tabela 6.1.1.2., para os parâmetros ali destacados, devem ser considerados de âmbito 
internacional ou nacional. Estes devem ser conservados independentes do seu potencial de uso, pois, são os geossítios mais importantes identificados. Os demais devem ser enquadrados de âmbito regional ou local.

\begin{tabular}{|c|c|}
\hline A - Características Intrínsecas & B - Uso Potencial \\
\hline $\mathrm{A} 1 \geq 3$ & \\
$\mathrm{~A} 3 \geq 4$ & $\mathrm{~B} 1 \geq 3$ \\
$\mathrm{~A} 6 \geq 3$ & $\mathrm{~B} 2 \geq 3$ \\
$\mathrm{~A} 9 \geq 3$ & \\
\hline
\end{tabular}

Tabela 6.1.1.2. Parâmetros analisados para classificação dos geossítios no âmbito internacional ou nacional e regional ou local.

O valor final para cada geossítio é obtido pela seguinte fórmula (Tabela 6.1.1.3.):

\begin{tabular}{|c|c|}
\hline $\begin{array}{c}\text { Geossítio de âmbito } \\
\text { internacional ou nacional }\end{array}$ & $\begin{array}{c}\text { Geossítio de âmbito } \\
\text { regional ou local }\end{array}$ \\
\hline $\mathrm{Q}=2 \mathrm{~A}+\mathrm{B}+1.5 \mathrm{C} / 3$ & $\mathrm{Q}=\mathrm{A}+\mathrm{B}+\mathrm{C} / 3$ \\
\hline
\end{tabular}

Tabela 6.1.1.3. Fórmula para obtenção do valor final dos geossítios.

Onde: $Q=$ Quantificação final da relevância do geossítio;

$A=$ média aritmética do valor intrínseco;

$\mathrm{B}=$ média aritmética para o uso potencial;

$\mathrm{C}=$ média aritmética para a necessidade de proteção.

\subsubsection{Método CPRM, GEOSSIT (201420)}

O Serviço Geológico do Brasil (CPRM) criou recentemente o GEOSSIT, que consiste de um aplicativo para o cadastramento, quantificação e valoração de geossítios por meio de uma base de dados do Sistema GEOBANK (GEOSSIT, 2014). Esta plataforma reúne uma série de critérios para caracterização de geossítios, que foram divididos em diferentes categorias: identificação do geossítio,

\footnotetext{
${ }^{20}$ A plataforma GEOSSIT foi lançada no ano de 2011, porém como referência adota-se aqui GEOSSIT (2014) por se tratar do ano em que os geossítios foram cadastrados na plataforma.
} 
enquadramento geológico, caracterização geológica, feições de relevo, interesse, conservação e quantificação de geossítios.

A quantificação de geossítios, testada neste trabalho, tem como base as metodologias propostas por Brilha (2005), apresentada anteriormente, e a metodologia de Garcia-Cortés \& Urquí (2009) para o inventário nacional da Espanha. Esta metodologia tem como objetivo a avaliação de lugares de interesse geológico (LIGs) e o seu agrupamento em domínios geológicos que compreendem o território espanhol. Estes locais são selecionados e avaliados criteriosamente por uma equipe de trabalho composta por especialistas de modo a eleger os elementos mais significativos da geodiversidade. Todos os LIGs selecionados são enquadrados de acordo com um nível de relevância (regional, nacional ou internacional) e categoria de uso (cientifico, didático, turístico/recreativo). A valoração e seleção definitiva dos LIGs são feitas de acordo com diferentes critérios compilados em quatro classes de valor (intrínseco, intrínseco e de uso, de uso e de uso e proteção). Alguns destes critérios foram adaptados pela CPRM e compõem, junto aos parâmetros propostos por Brilha (2005), um conjunto de 36 critérios, os quais foram agrupados em 4 categorias (vulnerabilidade, características intrínsecas, uso potencial e necessidade de proteção) utilizada no GEOSSIT (Tabela 6.1.2.1).

\begin{tabular}{|l|c|c|l|}
\hline \multicolumn{1}{|c|}{ Vulnerabilidade } & Peso & \multicolumn{2}{|c|}{ A - Características intrínsecas } \\
\hline Ameaças antrópicas & 15 & A1 & Abundância / raridade \\
\hline Interesse para exploração mineral & 15 & A2 & Extensão \\
\hline Ameaças naturais & 15 & A3 & Grau de conhecimento científico \\
\hline Fragilidade intrínseca & 10 & A4 & $\begin{array}{l}\text { Utilidade como modelo para ilustração de } \\
\text { processos geológicos }\end{array}$ \\
\hline Regime de proteção do local & 10 & A5 & $\begin{array}{l}\text { Diversidade de elementos de interesse pelo } \\
\text { conteúdo }\end{array}$ \\
\hline Proteção física ou indireta & 10 & A6 & Local - tipo \\
\hline Acessibilidade & 10 & A7 & Associação com elementos culturais \\
\hline Regime de propriedade do local & 5 & A8 & Associação com elementos naturais \\
\hline $\begin{array}{l}\text { Densidades de população (agressão } \\
\text { potencial) }\end{array}$ & 5 & A9 & Estado de conservação \\
\hline $\begin{array}{l}\text { Proximidades de área recreativas (agressão } \\
\text { potencial) }\end{array}$ & 5 & A10 & Utilização da imagem na divulgação turística \\
\hline
\end{tabular}

Tabela 6.1.2.1. Critérios de quantificação de relevância dos geossítios utilizados na plataforma GEOSSIT (2014). Adaptada de Brilha (2005) e Garcia-Cortés \& Urquí (2009). 


\begin{tabular}{|l|l|l|l|}
\hline \multicolumn{2}{|c|}{ B - Uso potencial } & \multicolumn{2}{c|}{ C - Necessidade de proteção } \\
\hline B1 & $\begin{array}{l}\text { Possibilidades de realizar as } \\
\text { atividades propostas }\end{array}$ & C1 & Ameaças atuais ou potenciais \\
\hline B2 & Condições de observação & C2 & Situação atual \\
\hline B3 & $\begin{array}{l}\text { Possibilidades de coleta de } \\
\text { materiais }\end{array}$ & C3 & Interesse para exploração mineral \\
\hline B4 & Acessibilidade & C4 & Valor dos terrenos \\
\hline B5 & Proximidade de povoação & C5 & Regime de propriedade \\
\hline B6 & $\begin{array}{l}\text { População a ser beneficiada com a } \\
\text { utilização/divulgação do geossítio }\end{array}$ & C6 & Fragilidade (Perante ação humana) \\
\hline B7 & Condições socioeconômicas & C7 & Proximidade de áreas recreativas \\
\hline B8 & Utilização didática & & \multicolumn{2}{|c|}{} \\
\hline B9 & Conteúdo divulgativo & &
\end{tabular}

Tabela 6.1.2.1. Critérios de quantificação de relevância dos geossítios utilizados na plataforma GEOSSIT (2014). Adaptada de Brilha (2005) e Garcia-Cortés \& Urquí (2009).

O cálculo de relevância dos geossítios, de acordo com a CPRM é dado pelas seguintes fórmulas (Tabela 6.1.2.2):

\begin{tabular}{|l|c|l|}
\hline $\begin{array}{l}\text { E - Relevância } \\
\text { do Geossítio }\end{array}$ & Fórmula & \multicolumn{1}{c|}{ Orientações } \\
\hline $\begin{array}{l}\text { Relevância } \\
\text { Regional }\end{array}$ & $(\mathrm{A}+\mathrm{B}+\mathrm{C}) / 3$ & \\
\hline $\begin{array}{l}\text { Relevância } \\
\text { Nacional }\end{array}$ & $(2 \mathrm{~A}+\mathrm{B}+1,5 \mathrm{C}) / 3$ & $\begin{array}{l}\text { Classificação adotada quando os itens } \\
\mathrm{A} 1, \mathrm{~A} 6, \mathrm{~A} 9, \mathrm{~B} 1 \text { e } \mathrm{B} 2 \text { são } \\
\text { simultaneamente maiores ou iguais a } \\
3 \text { e A3 maior ou igual a 4 }\end{array}$ \\
\hline $\begin{array}{l}\text { Relevância } \\
\text { Internacional }\end{array}$ & $(2 \mathrm{~A}+\mathrm{B}+1,5 \mathrm{C}) / 3$ & $\begin{array}{l}\text { Classificação adotada quando os itens } \\
\text { A1, A3, A9, B1 e B2 são } \\
\text { simultaneamente iguais ou maiores a } \\
4 \text { e A6 igual a 5. }\end{array}$ \\
\hline
\end{tabular}

Tabela 6.1.2.2. Fórmulas para o cálculo a relevância dos geossítios.

Posteriormente, a plataforma calcula para cada geossítio o Interesse didático (Id), científico (Ic) e turístico (It) de acordo com os parâmetros apresentados na tabela 6.1.2.3. 


\begin{tabular}{|c|c|c|c|}
\hline \multirow{2}{*}{ F - Interesse } & Científico & Didático & $\begin{array}{c}\text { Turístico ou } \\
\text { Recreativo }\end{array}$ \\
\hline & Peso & Peso & Peso \\
\hline A1 - Abundância / raridade & 10 & 5 & 0 \\
\hline A3 - Grau de conhecimento científico & 15 & 10 & 0 \\
\hline $\begin{array}{l}\text { A4 - Utilidade como modelo para ilustração de processos } \\
\text { geológicos }\end{array}$ & 20 & 5 & 0 \\
\hline A5 - Diversidade de elementos de interesse pelo conteúdo & 10 & 10 & 0 \\
\hline A6 - Local - tipo & 20 & 5 & 0 \\
\hline A7 - Associação com elementos culturais & 0 & 5 & 5 \\
\hline A9 - Estado de conservação & 10 & 5 & 5 \\
\hline A10 - Utilização da imagem na divulgação turística & 0 & 5 & 15 \\
\hline B1 - Possibilidades de realizar as atividades propostas & 0 & 5 & 5 \\
\hline B2 - Condições de observação & 5 & 5 & 5 \\
\hline B4 - Acessibilidade & 5 & 10 & 10 \\
\hline B5 - Proximidade de povoação & 0 & 5 & 5 \\
\hline $\begin{array}{l}\text { B6 - População a ser beneficiada com a } \\
\text { utilização/divulgação do geossítio }\end{array}$ & 0 & 5 & 5 \\
\hline B7 - Condições socioeconômicas & 0 & 0 & 10 \\
\hline B8 - Utilização didática & 0 & 20 & 0 \\
\hline B9 - Conteúdo divulgativo & 0 & 0 & 15 \\
\hline C6 - Fragilidade (Perante ação humana) & 5 & 0 & 15 \\
\hline C7 - Proximidade de áreas recreativas & 0 & 0 & 5 \\
\hline
\end{tabular}

Tabela 6.1.2.3 - Parâmetros para o cálculo de Interesse didático (Id), Científico (Ic) e Turístico (It) no GEOSSIT. CPRM (2014) adaptada Garcia-Cortés \& Urquí (2009).

Ao final, a Prioridade de Proteção (PP) de cada geossítio é calculada a partir da média aritmética dos valores obtidos para tipo de Interesse somado ao valor obtido para a vulnerabilidade (Tabela 6.1.2.4 a/b).

\begin{tabular}{|l|l|l|l|l|}
\hline \multicolumn{5}{|c|}{ G - Prioridade de Proteção } \\
\hline Pelo Interesse & Valor & & Vulnerabilidade & Soma \\
\hline Científico (Ic) & & & & \\
\hline Didático (Id) & & \multirow{3}{*}{+} & & \\
\hline Turístico (It) & & & & \\
\hline Global (Ig) & & & & \\
\cline { 5 - 5 } & & & & \\
\cline { 5 - 5 }
\end{tabular}

\begin{tabular}{|l|l|}
\hline \multicolumn{1}{|c|}{ Soma } & Prioridade de Proteção \\
\hline $0<=$ Soma $<=400$ & A longo prazo \\
\hline $400<$ Soma $<=700$ & A médio prazo \\
\hline $700<$ Soma $<=900$ & A curto prazo \\
\hline $900<$ Soma $<=1000$ & Urgente \\
\hline
\end{tabular}

Tabela 6.1.2.4 - a) Critérios para o cálculo da Prioridade de Proteção dos geossítios no GEOSSIT; b) "Ranking" na Prioridade de Proteção dos geossítios. CPRM (2014) adaptada Garcia-Cortés \& Urquí (2009). Onde Ig $=(\mathrm{Ic}+\mathrm{Id}+\mathrm{It}) / 3$ 
6.1.3. Método de Pereira (2010)

Pereira (2010), baseando-se na análise de propostas pré-existentes, tais como Brilha (2005), Pralong (2005), Pereira (2006), Garcia-Cortés \& Urquí (2009), dentre outros, apresenta um metodologia para quantificação de relevância de geossítios da Chapada Diamantina - BA. Esta metodologia utiliza conjunto de 20 parâmetros (Tabela 6.1.3.1), sendo alguns deles comuns a todas as metodologias analisadas e considerados relevantes à análise do patrimônio geológico, adicionalmente foram inseridos novos parâmetros.

Os parâmetros identificados foram agrupados em 4 categorias: (i) Valor intrínseco $(\mathrm{Vi})$, reúne os parâmetros relacionados as características inerentes ao geossítios; (ii) Valor Científico (Vci), reúne os parâmetros referente a pesquisas cientificas, representatividade dos conteúdos, potencialidade didática de cada local; (iii) Valor Turístico (Vtur), reúne os parâmetros que permitem avaliar o uso turístico de cada local; (iv) Valor de Uso/Gestão (Vug) reúne os parâmetros indicativos dos impactos sociais e viabilidade de utilização do geossítio (PEREIRA, 2010).

\begin{tabular}{|l|l|l|l|}
\hline \multicolumn{2}{|c|}{ A - Valor Intrínseco (Vi) } & \multicolumn{2}{|c|}{ B - Valor Científico (Vci) } \\
\hline A1 & $\begin{array}{l}\text { Vulnerabilidade associada a } \\
\text { processos naturais }\end{array}$ & B1 & $\begin{array}{l}\text { Objeto de referências } \\
\text { bibliográficas (grau de } \\
\text { conhecimento científico) }\end{array}$ \\
\hline A2 & Abundância/ Raridade & B2 & $\begin{array}{l}\text { Representatividade de } \\
\text { materiais e processos } \\
\text { geológicos }\end{array}$ \\
\hline A3 & Integridade & B3 & $\begin{array}{l}\text { Diversidade de interesses/ } \\
\text { temáticas associados }\end{array}$ \\
\hline A4 & $\begin{array}{l}\text { Variedade de elementos da } \\
\text { geodiversidade }\end{array}$ & B4 & Relevância didática \\
\hline
\end{tabular}

Tabela 6.1.3.1 Critérios de quantificação de relevância dos geossítio. Adaptada de Pereira (2010). 


\begin{tabular}{|l|l|l|l|}
\hline \multicolumn{2}{|c|}{ C - Valor Turístico (Vtur) } & \multicolumn{2}{c|}{ D - Valor de Uso/Gestão (Vug) } \\
\hline C1 & Aspecto estético & D1 & Relevância cultural \\
\hline C2 & Acessibilidade & D2 & Relevância econômica \\
\hline C3 & Presença de infraestrutura & D3 & Nível oficial de proteção \\
\hline C4 & $\begin{array}{l}\text { Existência de utilização em } \\
\text { curso }\end{array}$ & D4 & Passível de utilização econômica \\
\hline C5 & $\begin{array}{l}\text { Presença de mecanismos de } \\
\text { controle de visitantes }\end{array}$ & D5 & $\begin{array}{l}\text { Vulnerabilidade associada ao uso } \\
\text { antrópico }\end{array}$ \\
\hline \multirow{2}{*}{} & D6 & $\begin{array}{l}\text { População do núcleo urbano mais } \\
\text { próximo }\end{array}$ \\
\cline { 3 - 5 } & D7 & $\begin{array}{l}\text { Condições socioeconômicas dos } \\
\text { núcleos urbanos mais próximos }\end{array}$ \\
\cline { 3 - 5 }
\end{tabular}

Tabela 6.1.3.1 Critérios de quantificação de relevância dos geossítio. Adaptada de Pereira (2010).

O valor de relevância de cada geossítio é calculado a partir da média aritmética dos valores obtidos para cada parâmetro dentro de cada categoria (Tabela 6.1.3.2).

\begin{tabular}{|l|l|}
\hline \multicolumn{2}{|c|}{ Cálculo do Valor da Relevância } \\
\hline Valor Intrínseco & $(\mathrm{Vi})=\mathrm{A} 1+\mathrm{A} 2+\mathrm{A} 3+\mathrm{A} 4 / 4$ \\
\hline Valor Científico & $(\mathrm{Vc})=\mathrm{B} 1+\mathrm{B} 2+\mathrm{B} 3+\mathrm{B} 4 / 4$ \\
\hline Valor Turístico & $(\mathrm{Vtur})=\mathrm{C} 1+\mathrm{C} 2+\mathrm{C} 3+\mathrm{C} 4+\mathrm{C} 5 / 5$ \\
\hline Valor de Uso / Gestão & $(\mathrm{Vug})=\mathrm{D} 1+\mathrm{D} 2+\mathrm{D} 3+\mathrm{D} 4+\mathrm{D} 5+\mathrm{D} 6+\mathrm{D} 7 / 7$ \\
\hline
\end{tabular}

Tabela 6.1.3.2. Fórmulas para o cálculo do valor da relevância dos geossítio. Adaptada de Pereira (2010).

A partir dos resultados obtidos para cada categoria são calculados: (i) Valor de Uso Científico (VUC), que expressa à relevância cientifica do geossítio; (ii) Valor de Uso Turístico, que indica o potencial de uso como atrativo turístico de cada geossítio; (iii) Valor de Conservação (VC) dos geossítios, que se refere à importância de conservação; (iv) Ranking de Relevância (R) do conjunto de geossítios que permite realizar a seriação dos geossítios de acordo com o tipo de uso e a classificação no âmbito local, regional, nacional e internacional. Assim, na tabela 6.1.3.3, temos que: 


\begin{tabular}{|c|}
\hline Valor de Uso dos Geossítios \\
\hline $\begin{array}{l}\text { Valor de Uso Científico (VUC) } \\
\text { VUC }=\left(2^{*} \mathrm{Vi}+3^{*} \mathrm{Vci}\right) / 5\end{array}$ \\
\hline $\begin{array}{l}\text { Valor de Uso Turístico (VUT) } \\
\text { VUT }=\left(3^{*} \text { Vtur }+2^{*} \text { Vug }\right) / 5\end{array}$ \\
\hline $\begin{array}{l}\text { Valor de Conservação (VC) } \\
\text { VC }=\left(3^{*} \mathrm{Vi}+\mathrm{Vci}+\mathrm{Vug}\right) / 5\end{array}$ \\
\hline $\begin{array}{l}\text { Ranking de relevância - R } \\
R=\left\{2^{*}\left[(\mathrm{VUC} / 20)^{*} 100\right]+\left[(\mathrm{VUT} / 20)^{*} 100\right]\right\} / 3\end{array}$ \\
\hline
\end{tabular}

Tabela 6.1.3.3. Fórmulas para o cálculo do valor de uso dos geossítio. Adaptada de Pereira (2010).

A seriação final do geossítio é apresentada a seguir de acordo com a Tabela 6.1.3.4.

\begin{tabular}{|l|l|}
\hline \multicolumn{2}{|c|}{ Relevância do Geossítio } \\
\hline Geossítio de relevância local & $\mathrm{R}<10$ \\
\hline Geossítio de relevância regional & $\begin{array}{l}10<\mathrm{R}<\text { valor médio obtido } \\
\text { para a relevância do conjunto } \\
\text { de geossítios avaliados }\end{array}$ \\
\hline Geossítio de relevância nacional & $\begin{array}{l}\mathrm{R}>\text { valor médio obtido para a } \\
\text { relevância do conjunto de } \\
\text { geossítios avaliados }\end{array}$ \\
\hline Geossítio de relevância internacional & $\begin{array}{l}\mathrm{R}>\text { valor médio obtido para a } \\
\text { relevância do conjunto de } \\
\text { geossítios avaliados e A2 e A3 } \geq \\
3 ; \mathrm{B} 1, \mathrm{~B} 2, \mathrm{C} 2, \mathrm{C} 3 \geq 2 .\end{array}$ \\
\hline
\end{tabular}

Tabela 6.1.3.4. Critérios para a seriação da relevância dos geossítio. Adaptada de Pereira (2010).

\subsection{Resultados da Quantificação}

A seguir são apresentados os resultados obtidos para a quantificação dos geossítios inventariados em Ubatuba. Inicialmente serão apresentados os resultados obtidos pelo método de Brilha (2005), seguido dos resultados obtidos pelo método GEOSSIT (2014) e, finalmente os resultados obtidos pelo método de Pereira (2010). 
Com o intuito de adequar os três métodos escolhidos ao contexto da região enfocada, esta etapa envolveu uma análise minuciosa do conjunto de parâmetros e quando necessário à adaptação para a realidade local.

No método de Brilha (2005), para o parâmetro A3 consideraram-se como publicações também os Trabalhos de Conclusão de Curso (TCC) ou Trabalho Final de Graduação (TF) e os trabalhos apresentados em Congressos nacionais e internacionais. Em C2, por se tratar de categorias distintas dentro do sistema de Unidade de Conservação (Capítulo 3), considerou-se "(3) geossítios incluídos em área de proteção legal (Parque/APA)" como "(1) geossítios incluídos em Unidade de conservação já implantada".

No método GEOSSIT (2014) em C3, os valores médios dos terrenos foram calculados a partir de dados obtidos por diferentes consultas em sites regionais.

No método de Pereira (2010) as adaptações feitas referem-se aos parâmetros B3 e B4, onde se considerou como tipos de interesse os quais os geossítios haviam sido agrupados (ígneo, metamórfico e tectônico; ígneo e tectônico; geomorfológico e histórico-cultural).

\subsubsection{Método de Brilha (2005)}

Os resultados obtidos de acordo com este método indicam que a as estratégias de Geoconservação devem ser aplicadas na seguinte ordem:

$1^{\circ}$ Monzogranito llha Anchieta

$1^{\circ}$ Brecha Magmática llha Anchieta

$2^{\circ}$ Gruta que Chora

$3^{\circ}$ Xenólitos do Manto e Cones de Explosão

$4^{\circ}$ Praia do Cedro do Sul

$5^{\circ}$ Pedra do Sino de Ubatuba

$6^{\circ}$ Pedreira Itamambuca

$7^{\circ}$ Pico do Corcovado

$8^{\circ}$ Charnockito Ubatuba

$9^{\circ}$ Praia da Ponta Aguda 
A tabela 6.2.1.1 apresenta os resultados finais obtidos para cada uma das categorias ( $A, B$ e $C$ ), "ranking" (a posição) de cada geossítio a ser submetido às estratégias de geoconservação e a classificação dos geossítios no âmbito Internacional/Nacional e Regional/Local.

\begin{tabular}{|l|c|c|c|c|c|c|}
\hline \multicolumn{7}{|c|}{ Resultado da quantificação pelo Método Brilha (2005) } \\
\hline \multicolumn{1}{|c|}{ Geossítio } & A & B & C & Valor final (Q) & Posição & Relevância \\
\hline Charnockito Ubatuba & 21,00 & 20,00 & 21,00 & 20,70 & $8^{\circ}$ & Regional/Local \\
\hline Praia do Cedro do Sul & 28,00 & 21,00 & 21,00 & 36,20 & $4^{\circ}$ & Internacional/Nacional \\
\hline Pedra do Sino de Ubatuba & 28,00 & 23,00 & 17,00 & 22,70 & $5^{\circ}$ & Regional/Local \\
\hline Praia da Ponta Aguda & 19,00 & 23,00 & 17,00 & 19,70 & $9^{\circ}$ & Regional/Local \\
\hline Monzogranito Ilha Anchieta & 34,00 & 21,00 & 26,00 & 42,70 & $1^{\circ}$ & Internacional/Nacional \\
\hline Gruta que Chora & 29,00 & 24,00 & 26,00 & 40,30 & $2^{\circ}$ & Internacional/Nacional \\
\hline Brecha Magmática Ilha Anchieta & 35,00 & 19,00 & 26,00 & 42,70 & $1^{\circ}$ & Internacional/Nacional \\
\hline Xenólitos do Manto e Cones de Explosão & 30,00 & 26,00 & 23,00 & 40,20 & $3^{\circ}$ & Internacional/Nacional \\
\hline Pico do Corcovado & 24,00 & 13,00 & 26,00 & 21,00 & $7^{\circ}$ & Regional/Local \\
\hline Pedreira Itamambuca & 21,00 & 26,00 & 20,00 & 22,30 & $6^{\circ}$ & Regional/Local \\
\hline
\end{tabular}

Tabela 6.2.1.1 - Resultado final da quantificação (Q), ranking de geossítios e classificação dos geossítios no âmbito Internacional/Nacional ou Regional/Local pelo Método Brilha (2005).

Os valores atribuídos para cada parâmetro dentro das categorias $A, B$ e C são apresentados nos tabelas 6.2.1.2. a/b/c.

\begin{tabular}{|l|c|c|c|c|c|c|c|c|c|c|}
\hline \multirow{2}{*}{ Geossítio } & \multicolumn{9}{|c|}{ A - Características Intrínsecas } & \multicolumn{3}{c|}{ Soma } \\
\cline { 2 - 13 } & A1 & A2 & A3 & A4 & A5 & A6 & A7 & A8 & A9 & A \\
\hline Charnockito Ubatuba & 1 & 1 & 3 & 3 & 3 & 1 & 2 & 3 & 4 & 21,00 \\
\hline Praia do Cedro do Sul & 4 & 1 & 4 & 3 & 3 & 5 & 1 & 3 & 4 & 28,00 \\
\hline Pedra do Sino de Ubatuba & 5 & 1 & 1 & 5 & 3 & 5 & 1 & 3 & 4 & 28,00 \\
\hline Praia Ponta Aguda & 1 & 1 & 2 & 3 & 3 & 1 & 1 & 3 & 4 & 19,00 \\
\hline Monzogranito Ilha Anchieta & 4 & 1 & 5 & 5 & 2 & 5 & 5 & 3 & 4 & 34,00 \\
\hline Gruta que Chora & 5 & 1 & 4 & 3 & 2 & 5 & 2 & 3 & 4 & 29,00 \\
\hline Brecha Magmática Il ha Anchieta & 5 & 1 & 5 & 5 & 2 & 5 & 5 & 3 & 4 & 35,00 \\
\hline Xenólitos do Manto e Cones de Explosão & 5 & 1 & 5 & 5 & 1 & 5 & 1 & 3 & 4 & 30,00 \\
\hline Pico do Corcovado & 1 & 1 & 5 & 5 & 1 & 1 & 1 & 5 & 4 & 24,00 \\
\hline Pedreira Itamambuca & 1 & 1 & 5 & 3 & 1 & 1 & 2 & 3 & 4 & 21,00 \\
\hline
\end{tabular}




\begin{tabular}{|l|c|c|c|c|c|c|c|c|}
\hline \multirow{2}{*}{\multicolumn{1}{|c|}{ Geossítio }} & \multicolumn{9}{|c|}{ B - Uso Potencial } & Soma \\
\cline { 2 - 11 } & B1 & B2 & B3 & B4 & B5 & B6 & B7 & B \\
\hline Charnockito Ubatuba & 5 & 5 & 3 & 1 & 3 & 2 & 1 & 20,00 \\
\hline Praia do Cedro do Sul & 5 & 5 & 3 & 1 & 4 & 2 & 1 & 21,00 \\
\hline Pedra do Sino de Ubatuba & 5 & 3 & 3 & 5 & 4 & 2 & 1 & 23,00 \\
\hline Praia da Ponta Aguda & 5 & 5 & 3 & 3 & 3 & 3 & 1 & 23,00 \\
\hline Monzogranito Ilha Anchieta & 5 & 5 & 3 & 1 & 3 & 3 & 1 & 21,00 \\
\hline Gruta que Chora & 5 & 3 & 3 & 4 & 4 & 4 & 1 & 24,00 \\
\hline Brecha Magmática Ilha Anchieta & 5 & 3 & 3 & 1 & 3 & 3 & 1 & 19,00 \\
\hline Xenólitos do Manto e Cones de Explosão & 5 & 5 & 3 & 5 & 4 & 3 & 1 & 26,00 \\
\hline Pico do Corcovado & 1 & 3 & 3 & 1 & 2 & 2 & 1 & 13,00 \\
\hline Pedreira Itamambuca & 5 & 5 & 3 & 4 & 4 & 4 & 1 & 26,00 \\
\hline
\end{tabular}

\begin{tabular}{|c|c|c|c|c|c|c|c|}
\hline \multirow{2}{*}{ Geossítio } & \multicolumn{6}{|c|}{ C - Necessidade de Proteção } & \multirow{2}{*}{$\frac{\text { Soma }}{\text { C }}$} \\
\hline & $\mathrm{C} 1$ & $\mathrm{C} 2$ & $\mathrm{C} 3$ & $\mathrm{C} 4$ & C5 & $\mathrm{C} 6$ & \\
\hline Charnockito Ubatuba & 5 & 1 & 3 & 5 & 5 & 2 & 21,00 \\
\hline Praia do Cedro do Sul & 5 & 1 & 3 & 5 & 5 & 2 & 21,00 \\
\hline Pedra do Sino de Ubatuba & 5 & 1 & 3 & 1 & 5 & 2 & 17,00 \\
\hline Praia da Ponta Aguda & 5 & 1 & 3 & 1 & 5 & 2 & 17,00 \\
\hline Monzogranito Ilha Anchieta & 5 & 1 & 5 & 5 & 5 & 5 & 26,00 \\
\hline Gruta que Chora & 5 & 1 & 5 & 5 & 5 & 5 & 26,00 \\
\hline Brecha Magmática Ilha Anchieta & 5 & 1 & 5 & 5 & 5 & 5 & 26,00 \\
\hline Xenólitos do Manto e Cones de Explosão & 5 & 1 & 5 & 5 & 5 & 2 & 23,00 \\
\hline Pico do Corcovado & 5 & 1 & 5 & 5 & 5 & 5 & 26,00 \\
\hline Pedreira Itamambuca & 5 & 1 & 3 & 5 & 5 & 1 & 20,00 \\
\hline
\end{tabular}

Tabela 6.2.1.2 - a) b) e c) Valores atribuídos para cada parâmetro que compõem as categorias A, B e C do método Brilha (2005). Com destaque para o conjunto de parâmetros que classificam os geossítios no âmbito Internacional/Nacional ou Regional/Local.

\title{
6.2.2. Método GEOSSIT (2014)
}

Os resultados da quantificação obtidos pela plataforma GEOSSIT (2014) indicam que a prioridade de proteção dos geossítios efetuada na seguinte ordem:

\author{
$1^{\circ}$ Pedreira Itamambuca \\ $2^{\circ}$ Pedra do Sino de Ubatuba \\ $3^{\circ}$ Xenólitos do Manto e Cones de Explosão \\ $4^{\circ}$ Praia do Cedro do Sul \\ $5^{\circ}$ Charnockito Ubatuba \\ $6^{\circ}$ Gruta que Chora
}




\section{$7^{\circ}$ Monzogranito Ilha Anchieta \\ $8^{\circ}$ Brecha Magmática llha Anchieta \\ $9^{\circ}$ Praia da Ponta Aguda \\ $10^{\circ}$ Pico do Corcovado}

Os resultados finais obtidos para a o tipo de Interesse Científico (ic), Interesse Didático (id), Interesse Turístico ou Recreativo (It), o valor global (Ig) de cada geossítio, bem como os valores da vulnerabilidade (V), Prioridade de Proteção (PP) e a posição de cada geossítio são apresentados na tabela 6.2.2.1.

\begin{tabular}{|l|c|c|c|c|c|c|c|}
\hline \multicolumn{1}{|c|}{ Geossítio } & Ic & Id & It & Ig & V & PP & Posição \\
\hline Charnockito Ubatuba & 285 & 250 & 200 & 245,0 & 165 & 410,0 & $5^{\circ}$ \\
\hline Praia do Cedro do Sul & 380 & 265 & 180 & 275,0 & 170 & 445,0 & $4^{\circ}$ \\
\hline Pedra do Sino de Ubatuba & 370 & 265 & 210 & 281,7 & 195 & 476,7 & $2^{\circ}$ \\
\hline Praia da Ponta Aguda & 245 & 215 & 180 & 213,3 & 125 & 338,3 & $9^{\circ}$ \\
\hline Monzogranito Ilha Anchieta & 425 & 265 & 235 & 308,3 & 60 & 368,3 & $7^{\circ}$ \\
\hline Gruta que Chora & 400 & 290 & 280 & 323,3 & 70 & 393,3 & $6^{\circ}$ \\
\hline Brecha Magmática Ilha Anchieta & 420 & 260 & 210 & 296,7 & 60 & 356,7 & $8^{\circ}$ \\
\hline Xenólitos do Manto e Cones de Explosão & 415 & 290 & 215 & 306,7 & 145 & 451,7 & $3^{\circ}$ \\
\hline Pico do Corcovado & 285 & 180 & 210 & 225,0 & 45 & 270,0 & $10^{\circ}$ \\
\hline Pedreira Itamambuca & 255 & 290 & 260 & 268,3 & 275 & 543,3 & $1^{\circ}$ \\
\hline
\end{tabular}

Tabela 6.2.2.1 - Resultados finais para o tipo de interesse dos geossítios (Ic, Id, It, Ig), para a vulnerabilidade (V), Prioridade de Proteção (PP) e a posição de cada geossítios.

A tabela 6.2.2.2a/b/c/d apresenta os valores atribuídos para cada parâmetro e os resultados obtidos para cada categoria (Vulnerabilidade, Características Intrínsecas, Uso Potencial e Necessidade de Proteção).

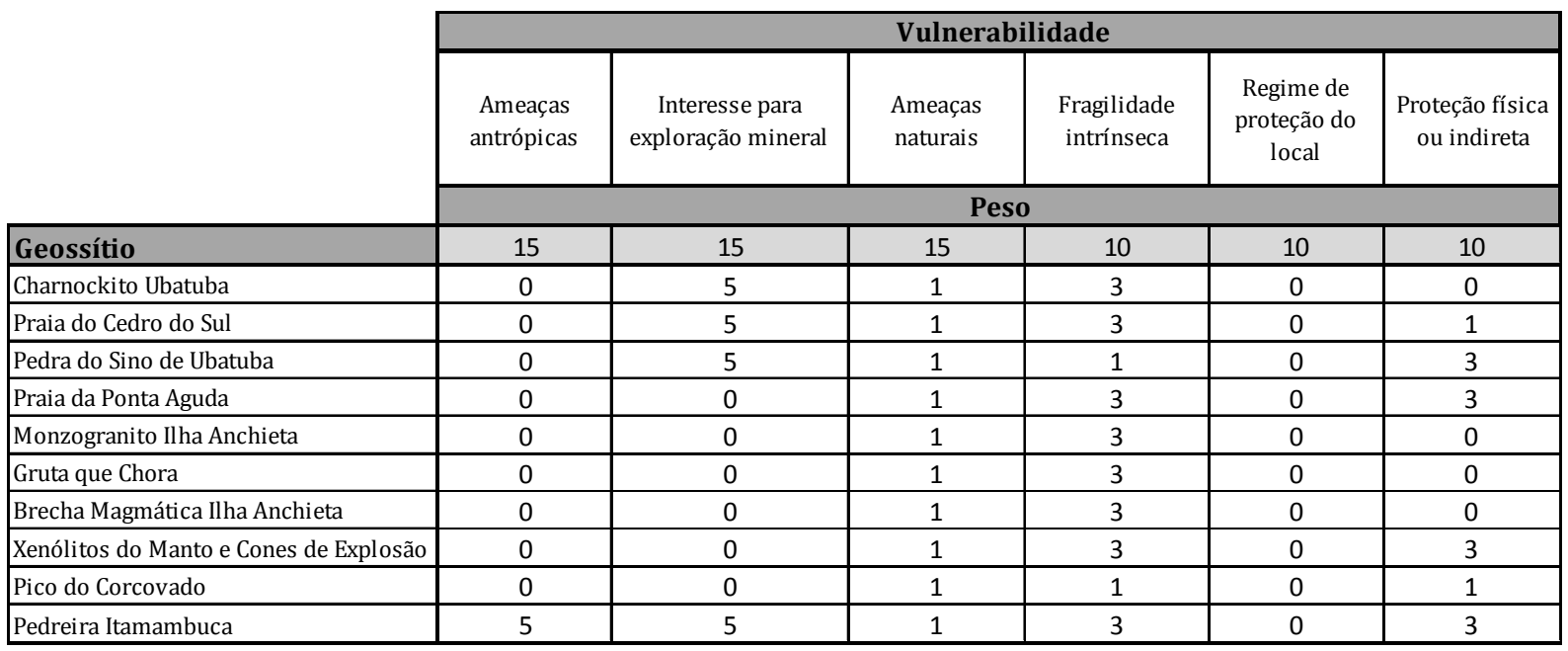




\begin{tabular}{|c|c|c|c|c|}
\hline \multicolumn{4}{|c|}{ Vulnerabilidade } & \\
\hline Acessibilidade & $\begin{array}{c}\text { Regime de } \\
\text { propriedade do } \\
\text { local }\end{array}$ & $\begin{array}{l}\text { Densidades de } \\
\text { população } \\
\text { (agressão } \\
\text { potencial) }\end{array}$ & $\begin{array}{l}\text { Proximidades de área } \\
\text { recreativas (agressão } \\
\text { potencial) }\end{array}$ & \\
\hline \multicolumn{4}{|c|}{ Peso } & Valor da \\
\hline 10 & 5 & 5 & 5 & Vulnerabilidade \\
\hline 1 & 1 & 1 & 5 & 165 \\
\hline 0 & 2 & 1 & 5 & 170 \\
\hline 3 & 1 & 1 & 5 & 195 \\
\hline 0 & 2 & 3 & 5 & 125 \\
\hline 0 & 1 & 1 & 1 & 60 \\
\hline 1 & 1 & 1 & 1 & 70 \\
\hline 0 & 1 & 1 & 1 & 60 \\
\hline 3 & 2 & 1 & 5 & 145 \\
\hline 0 & 1 & 1 & 0 & 45 \\
\hline 1 & 2 & 1 & 5 & 275 \\
\hline
\end{tabular}

Tabela 6.2.2.2 - a) Valor atribuído a cada parâmetro que compõem a categoria Vulnerabilidade e os valor final obtido para cada geossítio a partir do cálculo da média ponderada pelo método GEOSSIT (2014).

\begin{tabular}{|l|c|c|c|c|c|c|c|c|c|c|c|}
\hline \multirow{2}{*}{ Geossítio } & \multicolumn{9}{|c|}{ A - Características Intrínsecas } & Média \\
\cline { 2 - 13 } & $\mathrm{A} 1$ & $\mathrm{~A} 2$ & $\mathrm{~A} 3$ & $\mathrm{~A} 4$ & $\mathrm{~A} 5$ & $\mathrm{~A} 6$ & $\mathrm{~A} 7$ & $\mathrm{~A} 8$ & $\mathrm{~A} 9$ & $\mathrm{~A} 10$ & $\mathrm{~A}$ \\
\hline Charnockito Ubatuba & 1 & 1 & 4 & 4 & 3 & 1 & 3 & 3 & 4 & 1 & 2,50 \\
\hline Praia do Cedro do Sul & 5 & 1 & 4 & 3 & 3 & 5 & 0 & 3 & 4 & 1 & 2,90 \\
\hline Pedra do Sino de Ubatuba & 5 & 1 & 0 & 5 & 3 & 5 & 0 & 3 & 4 & 1 & 2,70 \\
\hline Praia da Ponta Aguda & 1 & 1 & 3 & 3 & 3 & 1 & 0 & 3 & 4 & 1 & 2,00 \\
\hline Monzogranito Ilha Anchieta & 5 & 1 & 4 & 5 & 2 & 5 & 1 & 3 & 4 & 1 & 3,10 \\
\hline Gruta que Chora & 5 & 1 & 2 & 5 & 2 & 5 & 3 & 3 & 4 & 2 & 3,20 \\
\hline Brecha Magmática Ilha Anchieta & 5 & 1 & 4 & 5 & 2 & 5 & 1 & 3 & 4 & 0 & 3,00 \\
\hline Xenólitos do Manto e Cones de Explosão & 5 & 1 & 4 & 5 & 1 & 5 & 0 & 3 & 4 & 1 & 2,90 \\
\hline Pico do Corcovado & 1 & 1 & 4 & 5 & 1 & 1 & 0 & 3 & 4 & 1 & 2,10 \\
\hline Pedreira Itamambuca & 1 & 1 & 4 & 3 & 1 & 1 & 3 & 3 & 4 & 3 & 2,40 \\
\hline
\end{tabular}

\begin{tabular}{|l|c|c|c|c|c|c|c|c|c|c|}
\hline \multicolumn{1}{|c|}{ Geossítio } & \multicolumn{9}{|c|}{ B- Uso Potencial } & Média \\
\cline { 2 - 13 } & B1 & B2 & B3 & B4 & B5 & B6 & B7 & B8 & B9 & B \\
\hline Charnockito Ubatuba & 4 & 5 & 3 & 2 & 3 & 2 & 1 & 1 & 1 & 2,44 \\
\hline Praia do Cedro do Sul & 4 & 5 & 3 & 1 & 4 & 2 & 1 & 1 & 1 & 2,44 \\
\hline Pedra do Sino de Ubatuba & 4 & 3 & 3 & 5 & 4 & 2 & 1 & 1 & 1 & 2,67 \\
\hline Praia da Ponta Aguda & 4 & 5 & 3 & 1 & 3 & 3 & 1 & 1 & 1 & 2,44 \\
\hline Monzogranito Ilha Anchieta & 4 & 5 & 3 & 1 & 2 & 3 & 1 & 1 & 1 & 2,33 \\
\hline Gruta que Chora & 4 & 3 & 3 & 4 & 4 & 3 & 1 & 1 & 1 & 2,67 \\
\hline Brecha Magmática Ilha Anchieta & 4 & 5 & 3 & 1 & 2 & 3 & 1 & 1 & 1 & 2,33 \\
\hline Xenólitos do Manto e Cones de Explosão & 4 & 5 & 2 & 4 & 4 & 3 & 1 & 1 & 1 & 2,78 \\
\hline Pico do Corcovado & 1 & 3 & 3 & 1 & 2 & 2 & 1 & 1 & 1 & 1,67 \\
\hline Pedreira Itamambuca & 4 & 5 & 3 & 3 & 3 & 3 & 1 & 3 & 1 & 2,89 \\
\hline
\end{tabular}




\begin{tabular}{|l|c|c|c|c|c|c|c|c|}
\hline \multirow{2}{*}{\multicolumn{1}{|c|}{ Geossítio }} & \multicolumn{7}{|c|}{ C - Necessidade de Proteção } & Média \\
\cline { 2 - 11 } & C1 & C2 & C3 & C4 & C5 & C6 & C7 & C \\
\hline Charnockito Ubatuba & 5 & 3 & 3 & 2 & 5 & 2 & 1 & 3,00 \\
\hline Praia do Cedro do Sul & 5 & 3 & 3 & 2 & 5 & 2 & 1 & 3,00 \\
\hline Pedra do Sino de Ubatuba & 5 & 3 & 3 & 2 & 3 & 2 & 1 & 2,71 \\
\hline Praia da Ponta Aguda & 5 & 3 & 5 & 2 & 5 & 2 & 1 & 3,29 \\
\hline Monzogranito Ilha Anchieta & 5 & 5 & 5 & 5 & 5 & 5 & 3 & 4,71 \\
\hline Gruta que Chora & 5 & 3 & 5 & 2 & 5 & 5 & 1 & 3,71 \\
\hline Brecha Magmática Ilha Anchieta & 5 & 5 & 5 & 5 & 5 & 4 & 4 & 4,71 \\
\hline Xenólitos do Manto e Cones de Explosão & 5 & 3 & 5 & 2 & 5 & 2 & 1 & 3,29 \\
\hline Pico do Corcovado & 5 & 5 & 5 & 3 & 5 & 5 & 5 & 4,71 \\
\hline Pedreira Itamambuca & 5 & 3 & 3 & 2 & 5 & 3 & 1 & 3,14 \\
\hline
\end{tabular}

Tabela 6.2.2.2 - b), c), e d) Valor atribuído a cada parâmetro que compõem as categorias Características Intrínsecas, Uso Potencial e Necessidade de Proteção e os valor final para cada geossítios obtido a partir do cálculo da média aritmética. Método GEOSSIT (2014).

Os resultados obtidos para o cálculo de relevância dos geossítios pelo GEOSSIT e a classificação no âmbito Regional, Nacional e Internacional são apresentados na tabela 6.2.2.3.

\begin{tabular}{|l|c|c|}
\hline \multicolumn{3}{|c|}{ Relevância dos Geossítios pelo método GEOSSIT (2014) } \\
\hline \multicolumn{1}{|c|}{ Geossítio } & Resultado (Q) & Relevância \\
\hline Charnockito Ubatuba & 2,65 & Regional \\
\hline Praia do Cedro do Sul & 4,25 & Internacional \\
\hline Pedra do Sino de Ubatuba & 2,69 & Regional \\
\hline Praia da Ponta Aguda & 2,58 & Regional \\
\hline Monzogranito Ilha Anchieta & 5,20 & Internacional \\
\hline Gruta que Chora & 3,19 & Regional \\
\hline Brecha Magmática Ilha Anchieta & 5,13 & Internacional \\
\hline Xenólitos do Manto e Cones de Explosão & 4,50 & Internacional \\
\hline Pico do Corcovado & 2,83 & Regional \\
\hline Pedreira Itamambuca & 2,81 & Regional \\
\hline
\end{tabular}

Tabela 6.2.2.3 - Resultados obtidos para $(Q)$ relevância dos geossítios e a classificação no âmbito Regional, Nacional e Internacional pelo método GEOSSIT (2014).

A tabela 6.2.2.4a/b/c/d apresentam os valores atribuídos a cada parâmetro a partir dos quais são calculados os diferentes tipos de interesse para cada geossítio (lc, Id e It) e o valor do Índice global dos geossítios (lg). 


\begin{tabular}{|c|c|c|c|c|c|c|c|c|c|c|c|c|c|c|c|c|c|c|}
\hline \multirow{4}{*}{ Geossítio } & \multicolumn{17}{|c|}{ Interesse Científico (Ic) } & \multirow[b]{4}{*}{ Média de Ic } \\
\hline & A1 & A3 & $\mathbf{A 4}$ & A5 & A6 & A7 & A9 & $\mathbf{A 1 0}$ & B1 & B2 & B4 & B5 & B6 & B7 & $\mathbf{B 8}$ & C6 & C7 & \\
\hline & \multicolumn{17}{|c|}{ 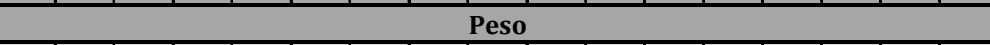 } & \\
\hline & 10 & 15 & 20 & 10 & 20 & 0 & 10 & 0 & 0 & 5 & 5 & 0 & 0 & 0 & 0 & 5 & 0 & \\
\hline Charnockito Ubatuba & 1 & 4 & 4 & 3 & 1 & 3 & 4 & 1 & 4 & 5 & 2 & 3 & 2 & 1 & 1 & 2 & 1 & 285 \\
\hline Praia do Cedro do Sul & 5 & 4 & 3 & 3 & 5 & 0 & 4 & 1 & 4 & 5 & 1 & 4 & 2 & 1 & 1 & 2 & 1 & 380 \\
\hline Pedra do Sino de Ubatuba & 5 & 0 & 5 & 3 & 5 & 0 & 4 & 1 & 4 & 3 & 5 & 4 & 2 & 1 & 1 & 2 & 1 & 370 \\
\hline Praia da Ponta Aguda & 1 & 3 & 3 & 3 & 1 & 0 & 4 & 1 & 4 & 5 & 1 & 3 & 3 & 1 & 1 & 2 & 1 & 245 \\
\hline Monzogranito Ilha Anchieta & 5 & 4 & 5 & 2 & 5 & 1 & 4 & 1 & 4 & 5 & 1 & 2 & 3 & 1 & 1 & 5 & 3 & 425 \\
\hline Gruta que Chora & 5 & 2 & 5 & 2 & 5 & 3 & 4 & 2 & 4 & 3 & 4 & 4 & 3 & 1 & 1 & 5 & 1 & 400 \\
\hline Brecha Magmática Ilha Anchieta & 5 & 4 & 5 & 2 & 5 & 1 & 4 & 0 & 4 & 5 & 1 & 2 & 3 & 1 & 1 & 4 & 4 & 420 \\
\hline Xenólitos do Manto e Cones de Explosão & 5 & 4 & 5 & 1 & 5 & 0 & 4 & 1 & 4 & 5 & 4 & 4 & 3 & 1 & 1 & 2 & 1 & 415 \\
\hline Pico do Corcovado & 1 & 4 & 5 & 1 & 1 & 0 & 4 & 1 & 1 & 3 & 1 & 2 & 2 & 1 & 1 & 5 & 5 & 285 \\
\hline Pedreira Itamambuca & 1 & 4 & 3 & 1 & 1 & 3 & 4 & 3 & 4 & 5 & 3 & 3 & 3 & 1 & 3 & 3 & 1 & 255 \\
\hline
\end{tabular}

\begin{tabular}{|c|c|c|c|c|c|c|c|c|c|c|c|c|c|c|c|c|c|c|}
\hline \multirow{4}{*}{ Geossítio } & \multicolumn{17}{|c|}{ Interesse Didático (Id) } & \\
\hline & $\mathbf{A 1}$ & A3 & A4 & A5 & A6 & A7 & A9 & A10 & B1 & B2 & B4 & B5 & B6 & \begin{tabular}{|l|} 
B7 \\
\end{tabular} & B8 & \begin{tabular}{|l|l|} 
C6 \\
\end{tabular} & C7 & \\
\hline & \multicolumn{17}{|c|}{ Peso } & \\
\hline & 5 & 10 & 5 & 10 & 5 & 5 & 5 & 5 & 5 & 5 & 10 & 5 & 5 & 0 & 20 & 0 & 0 & Média de Id \\
\hline Charnockito Ubatuba & 1 & 4 & 4 & 3 & 1 & 3 & 4 & 1 & 4 & 5 & 2 & 3 & 2 & 1 & 1 & 2 & 1 & 250 \\
\hline Praia do Cedro do Sul & 5 & 4 & 3 & 3 & 5 & 0 & 4 & 1 & 4 & 5 & 1 & 4 & 2 & 1 & 1 & 2 & 1 & 265 \\
\hline Pedra do Sino de Ubatuba & 5 & 0 & 5 & 3 & 5 & 0 & 4 & 1 & 4 & 3 & 5 & 4 & 2 & 1 & 1 & 2 & 1 & 265 \\
\hline Praia da Ponta Aguda & 1 & 3 & 3 & 3 & 1 & 0 & 4 & 1 & 4 & 5 & 1 & 3 & 3 & 1 & 1 & 2 & 1 & 215 \\
\hline Monzogranito Ilha Anchieta & 5 & 4 & 5 & 2 & 5 & 1 & 4 & 1 & 4 & 5 & 1 & 2 & 3 & 1 & 1 & 5 & 3 & 265 \\
\hline Gruta que Chora & 5 & 2 & 5 & 2 & 5 & 3 & 4 & 2 & 4 & 3 & 4 & 4 & 3 & 1 & 1 & 5 & 1 & 290 \\
\hline Brecha Magmática Ilha Anchieta & 5 & 4 & 5 & 2 & 5 & 1 & 4 & 0 & 4 & 5 & 1 & 2 & 3 & 1 & 1 & 4 & 4 & 260 \\
\hline Xenólitos do Manto e Cones de Explosão & 5 & 4 & 5 & 1 & 5 & 0 & 4 & 1 & 4 & 5 & 4 & 4 & 3 & 1 & 1 & 2 & 1 & 290 \\
\hline Pico do Corcovado & 1 & 4 & 5 & 1 & 1 & 0 & 4 & 1 & 1 & 3 & 1 & 2 & 2 & 1 & 1 & 5 & 5 & 180 \\
\hline Pedreira Itamambuca & 1 & 4 & 3 & 1 & 1 & 3 & 4 & 3 & 4 & 5 & 3 & 3 & 3 & 1 & 3 & 3 & 1 & 290 \\
\hline
\end{tabular}

\begin{tabular}{|c|c|c|c|c|c|c|c|c|c|c|c|c|c|c|c|c|c|c|}
\hline \multirow{4}{*}{ Geossítio } & \multicolumn{17}{|c|}{ Interesse Turístico ou Recreativo (It) } & \\
\hline & $\mathbf{A 1}$ & A3 & A4 & A5 & A6 & A7 & A9 & $\mathbf{A 1 0}$ & B1 & B2 & B4 & B5 & B6 & B7 & B8 & C6 & C7 & \\
\hline & \multicolumn{17}{|c|}{ Peso } & \\
\hline & 0 & 0 & 0 & 0 & 0 & 5 & 5 & 15 & 5 & 5 & 10 & 5 & 5 & 10 & 0 & 15 & 5 & Média de It \\
\hline Charnockito Ubatuba & 1 & 4 & 4 & 3 & 1 & 3 & 4 & 1 & 4 & 5 & 2 & 3 & 2 & 1 & 1 & 2 & 1 & 200 \\
\hline Praia do Cedro do Sul & 5 & 4 & 3 & 3 & 5 & 0 & 4 & 1 & 4 & 5 & 1 & 4 & 2 & 1 & 1 & 2 & 1 & 180 \\
\hline Pedra do Sino de Ubatuba & 5 & 0 & 5 & 3 & 5 & 0 & 4 & 1 & 4 & 3 & 5 & 4 & 2 & 1 & 1 & 2 & 1 & 210 \\
\hline Praia da Ponta Aguda & 1 & 3 & 3 & 3 & 1 & 0 & 4 & 1 & 4 & 5 & 1 & 3 & 3 & 1 & 1 & 2 & 1 & 180 \\
\hline \begin{tabular}{|l} 
Monzogranito Ilha Anchieta \\
\end{tabular} & 5 & 4 & 5 & 2 & 5 & 1 & 4 & 1 & 4 & 5 & 1 & 2 & 3 & 1 & 1 & 5 & 3 & 235 \\
\hline Gruta que Chora & 5 & 2 & 5 & 2 & 5 & 3 & 4 & 2 & 4 & 3 & 4 & 4 & 3 & 1 & 1 & 5 & 1 & 280 \\
\hline Brecha Magmática Ilha Anchieta & 5 & 4 & 5 & 2 & 5 & 1 & 4 & 0 & 4 & 5 & 1 & 2 & 3 & 1 & 1 & 4 & 4 & 210 \\
\hline Xenólitos do Manto e Cones de Explosão & 5 & 4 & 5 & 1 & 5 & 0 & 4 & 1 & 4 & 5 & 4 & 4 & 3 & 1 & 1 & 2 & 1 & 215 \\
\hline Pico do Corcovado & 1 & 4 & 5 & 1 & 1 & 0 & 4 & 1 & 1 & 3 & 1 & 2 & 2 & 1 & 1 & 5 & 5 & 210 \\
\hline Pedreira Itamambuca & 1 & 4 & 3 & 1 & 1 & 3 & 4 & 3 & 4 & 5 & 3 & 3 & 3 & 1 & 3 & 3 & 1 & 260 \\
\hline
\end{tabular}

Tabela 6.2.2.4 - a), b), c) Valores atribuídos aos parâmetros analisados para o cálculo de lc, Id e It do método GEOSSIT (2014) seguidos dos resultados finais obtidos para cada geossítio. 


\begin{tabular}{|l|c|c|c|c|}
\hline \multicolumn{1}{|c|}{ Geossítio } & Média de Ic & Média de Id & Média de It & Valor de Ig \\
\hline Charnockito Ubatuba & 285 & 250 & 200 & 245,0 \\
\hline Praia do Cedro do Sul & 380 & 265 & 180 & 275,0 \\
\hline Pedra do Sino de Ubatuba & 370 & 265 & 210 & 281,7 \\
\hline Praia da Ponta Aguda & 245 & 215 & 180 & 213,3 \\
\hline Monzogranito Ilha Anchieta & 425 & 265 & 235 & 308,3 \\
\hline Gruta que Chora & 400 & 290 & 280 & 323,3 \\
\hline Brecha Magmática Ilha Anchieta & 420 & 260 & 210 & 296,7 \\
\hline Xenólitos do Manto e Cones de Explosão & 415 & 290 & 215 & 306,7 \\
\hline Pico do Corcovado & 285 & 180 & 210 & 225,0 \\
\hline Pedreira Itamambuca & 255 & 290 & 260 & 268,3 \\
\hline
\end{tabular}

Tabela 6.2.2.4 - d) Valores obtidos para Ic, Id e It seguidos dos resultados finais para o Índice global dos geossítio. Ig $=(\mathrm{Ic}+\mathrm{Id}+\mathrm{It}) / 3$.

6.2.3. Método de Pereira (2010)

De acordo com o método de Pereira (2010) quantificação de relevância dos geossítios inicia-se com o cálculo da média aritmética dos valores obtidos para cada parâmetro dentro de cada categoria, como apresentados na tabela 6.2.3.1a/b/c/d.

\begin{tabular}{|l|c|c|c|c|c|}
\hline \multirow{2}{*}{\multicolumn{1}{c|}{ Geossítio }} & \multicolumn{4}{c|}{ Valor instríseco (Vi) } & \multirow{2}{*}{ Média de Vi } \\
\cline { 2 - 6 } & $\mathrm{A} 1$ & $\mathrm{~A} 2$ & $\mathrm{~A} 3$ & $\mathrm{~A} 4$ & \\
\hline Charnockito Ubatuba & 2 & 0 & 3 & 3 & 2,00 \\
\hline Praia do Cedro do Sul & 2 & 1 & 3 & 3 & 2,25 \\
\hline Pedra do Sino de Ubatuba & 2 & 4 & 3 & 3 & 3,00 \\
\hline Praia da Ponta Aguda & 2 & 1 & 3 & 3 & 2,25 \\
\hline Monzogranito Ilha Anchieta & 2 & 1 & 3 & 2 & 2,00 \\
\hline Gruta que Chora & 2 & 4 & 3 & 2 & 2,75 \\
\hline Brecha Magmática Ilha Anchieta & 2 & 4 & 3 & 2 & 2,75 \\
\hline Xenólitos do Manto e Cones de Explosão & 2 & 4 & 3 & 1 & 2,50 \\
\hline Pico do Corcovado & 2 & 0 & 3 & 1 & 1,50 \\
\hline Pedreira Itamambuca & 2 & 0 & 3 & 1 & 1,50 \\
\hline
\end{tabular}




\begin{tabular}{|c|c|c|c|c|c|}
\hline \multirow{2}{*}{ Geossítio } & \multicolumn{4}{|c|}{ Valor Científico (Vci) } & \multirow{2}{*}{ Média de Vci } \\
\hline & B1 & $\mathrm{B} 2$ & B3 & B4 & \\
\hline Charnockito Ubatuba & 4 & 4 & 2 & 2 & 3,00 \\
\hline Praia do Cedro do Sul & 3 & 4 & 2 & 2 & 2,75 \\
\hline Pedra do Sino de Ubatuba & 0 & 4 & 2 & 2 & 2,00 \\
\hline Praia da Ponta Aguda & 3 & 4 & 2 & 2 & 2,75 \\
\hline Monzogranito Ilha Anchieta & 4 & 4 & 2 & 2 & 3,00 \\
\hline Gruta que Chora & 2 & 4 & 2 & 2 & 2,50 \\
\hline Brecha Magmática Ilha Anchieta & 4 & 4 & 2 & 2 & 3,00 \\
\hline Xenólitos do Manto e Cones de Explosão & 3 & 4 & 2 & 2 & 2,75 \\
\hline Pico do Corcovado & 4 & 4 & 1 & 2 & 2,75 \\
\hline Pedreira Itamambuca & 4 & 4 & 1 & 4 & 3,25 \\
\hline
\end{tabular}

Tabela 6.2.3.1- a) e b) Valores atribuídos para cada parâmetro e a média aritmética para as categorias: Valor Intrínseco (Vi) e Valor Científico (Vci). Método Pereira (2010).

\begin{tabular}{|l|c|c|c|c|c|c|}
\hline \multirow{2}{*}{\multicolumn{1}{|c|}{ Geossítio }} & \multicolumn{5}{c|}{ Valor Turístico (Vtur) } & \multirow{2}{*}{ Média de Vtur } \\
\cline { 2 - 7 } & C1 & C2 & C3 & C4 & C5 & \\
\hline Charnockito Ubatuba & 2 & 2 & 2 & 3 & 0 & 1,80 \\
\hline Praia do Cedro do Sul & 2 & 0 & 2 & 3 & 0 & 1,40 \\
\hline Pedra do Sino de Ubatuba & 2 & 4 & 0 & 3 & 2 & 2,20 \\
\hline Praia da Ponta Aguda & 2 & 2 & 0 & 1 & 0 & 1,00 \\
\hline Monzogranito Ilha Anchieta & 2 & 1 & 2 & 4 & 4 & 2,60 \\
\hline Gruta que Chora & 2 & 2 & 0 & 3 & 0 & 1,40 \\
\hline Brecha Magmática Ilha Anchieta & 2 & 0 & 0 & 0 & 4 & 1,20 \\
\hline Xenólitos do Manto e Cones de Explosão & 2 & 2 & 0 & 1 & 0 & 1,00 \\
\hline Pico do Corcovado & 4 & 0 & 2 & 3 & 4 & 2,60 \\
\hline Pedreira Itamambuca & 2 & 2 & 0 & 1 & 0 & 1,00 \\
\hline
\end{tabular}

\begin{tabular}{|l|c|c|c|c|c|c|c|c|}
\hline \multirow{2}{*}{\multicolumn{1}{|c|}{ Geossítio }} & \multicolumn{7}{|c|}{ Valor de Uso / Gestão (Vug) } & \multirow{2}{*}{ Média de Vug } \\
\cline { 2 - 10 } & D1 & D2 & D3 & D4 & D5 & D6 & D7 & \\
\hline Charnockito Ubatuba & 3 & 3 & 4 & 2 & 4 & 1 & 1 & 2,57 \\
\hline Praia do Cedro do Sul & 0 & 3 & 4 & 2 & 4 & 1 & 1 & 2,14 \\
\hline Pedra do Sino de Ubatuba & 0 & 3 & 4 & 2 & 2 & 1 & 1 & 1,86 \\
\hline Praia da Ponta Aguda & 0 & 4 & 4 & 2 & 4 & 2 & 1 & 2,43 \\
\hline Monzogranito Ilha Anchieta & 1 & 4 & 4 & 2 & 4 & 2 & 1 & 2,57 \\
\hline Gruta que Chora & 4 & 4 & 4 & 2 & 4 & 4 & 1 & 3,29 \\
\hline Brecha Magmática Ilha Anchieta & 0 & 4 & 4 & 2 & 4 & 2 & 1 & 2,43 \\
\hline Xenólitos do Manto e Cones de Explosão & 0 & 4 & 4 & 2 & 0 & 2 & 1 & 1,86 \\
\hline Pico do Corcovado & 0 & 4 & 4 & 2 & 4 & 1 & 1 & 2,29 \\
\hline Pedreira Itamambuca & 4 & 3 & 4 & 2 & 4 & 4 & 1 & 3,14 \\
\hline
\end{tabular}

Tabela 6.2.3.1- c) e d) Valores atribuídos para cada parâmetro e a média aritmética para as categorias: Valor Turístico (Vtur) e Valor de Uso/Gestão (Vug). Método Pereira (2010). 
A partir dos valores obtidos para as categorias $\mathrm{Vi}, \mathrm{Vci}$, Vtur e Vug foram calculados o Valor Uso Científico (VUC), Valor Uso Turístico (VUT), Valor de Conservação (VC) e o Ranking de Relevância - R e estabelecida a posição de cada geossítio, apresentados na tabela 6.2.3.2.

Assim, a seriação dos geossítios inventariados em Ubatuba seguiria a seguinte ordem:

$1^{\circ}$ Monzogranito llha Anchieta

$2^{\circ}$ Brecha Magmática llha Anchieta

$3^{\circ}$ Gruta que Chora

$4^{\circ}$ Charnockito Ubatuba

$5^{\circ}$ Pico do Corcovado

$6^{\circ}$ Pedreira Itamambuca

$7^{\circ}$ Pedra do Sino de Ubatuba

$8^{\circ}$ Praia do Cedro do Sul

$9^{\circ}$ Praia da Ponta Aguda

$10^{\circ}$ Xenólitos do Manto e Cones de Explosão

\begin{tabular}{|c|c|c|c|c|c|}
\hline \multirow[b]{2}{*}{ Geossítio } & \multicolumn{5}{|c|}{ Valor de Uso dos Geossítios } \\
\hline & \begin{tabular}{|c|} 
Valor de Uso \\
Científico (VUC)
\end{tabular} & $\begin{array}{l}\text { Valor de Uso } \\
\text { Turístico (VUT) }\end{array}$ & \begin{tabular}{|c|} 
Valor de \\
Conservação (VC)
\end{tabular} & $\begin{array}{c}\text { Ranking de } \\
\text { Relevânvia - R }\end{array}$ & Posição \\
\hline Charnockito Ubatuba & 2,60 & 2,11 & 2,31 & 12,18 & $4^{\circ}$ \\
\hline Praia do Cedro do Sul & 2,55 & 1,70 & 2,33 & 11,33 & $8^{\circ}$ \\
\hline Pedra do Sino de Ubatuba & 2,40 & 2,06 & 2,57 & 11,44 & $7^{\circ}$ \\
\hline Praia da Ponta Aguda & 2,55 & 1,57 & 2,39 & 11,12 & $9^{\circ}$ \\
\hline Monzogranito Ilha Anchieta & 2,60 & 2,59 & 2,31 & 12,98 & $1^{\circ}$ \\
\hline Gruta que Chora & 2,60 & 2,15 & 2,81 & 12,26 & $3^{\circ}$ \\
\hline Brecha Magmática Ilha Anchieta & 2,90 & 1,69 & 2,74 & 12,49 & $2^{\circ}$ \\
\hline Xenólitos do Manto e Cones de Explosão & 2,65 & 1,34 & 2,42 & 11,07 & $10^{\circ}$ \\
\hline Pico do Corcovado & 2,25 & 2,47 & 1,91 & 11,62 & $5^{\circ}$ \\
\hline Pedreira Itamambuca & 2,55 & 1,86 & 2,18 & 11,60 & $6^{\circ}$ \\
\hline
\end{tabular}

\begin{tabular}{|c|c|c|c|}
\hline Média de VUC & Média de VUT & Média de VC & Média de R \\
\hline 2,57 & 1,95 & 2,40 & 11,81 \\
\hline
\end{tabular}

Tabela 6.2.3.2 - Resultados obtidos para o cálculo dos valores de VUC, VUT, VC e o Ranking de Relevância - R, com a respectiva posição de cada geossítio. Seguido do valor médio obtido para cada categoria. Método Pereira (2010). 
Finalmente, os geossítios foram classificados no âmbito de relevância local, regional nacional e internacional (tabela 6.2.3.3).

\begin{tabular}{|c|c|c|}
\hline Geossítio & \multicolumn{2}{|c|}{ Relevância } \\
\hline Charnockito Ubatuba & $\begin{array}{c}\mathrm{R}>\text { valor médio obtido para a } \\
\text { relevância do conjunto de geossítios } \\
\text { avaliados }\end{array}$ & Relevância Nacional \\
\hline Praia do Cedro do Sul & \multirow{3}{*}{$\begin{array}{c}10<\mathrm{R}<\text { valor médio obtido para a } \\
\text { relevância do conjunto de geossítios } \\
\text { avaliados }\end{array}$} & \multirow{3}{*}{ Relevância Regional } \\
\hline Pedra do Sino de Ubatuba & & \\
\hline Praia da Ponta Aguda & & \\
\hline Monzogranito Ilha Anchieta & \multirow{3}{*}{$\begin{array}{c}\mathrm{R}>\text { valor médio obtido para a } \\
\text { relevância do conjunto de geossítios } \\
\text { avaliados }\end{array}$} & \multirow{3}{*}{ Relevância Nacional } \\
\hline Gruta que Chora & & \\
\hline Brecha Magmática Ilha Anchieta & & \\
\hline Xenólitos do Manto e Cones de Explosão & \multirow{3}{*}{$\begin{array}{c}10<\mathrm{R}<\text { valor médio obtido para a } \\
\text { relevância do conjunto de geossítios } \\
\text { avaliados }\end{array}$} & \multirow{3}{*}{ Relevância Regional } \\
\hline Pico do Corcovado & & \\
\hline Pedreira Itamambuca & & \\
\hline
\end{tabular}

Tabela 6.2.3.3 - Resultados obtidos para definição de relevância em escala local, regional, nacional e internacional. Média de $R=11,81$. Método de Pereira (2010). 


\section{DISCUSSÃO DOS RESULTADOS E CONCLUSÕES}

Neste capítulo apresentam-se a discussão dos resultados e as conclusões obtidas durante o desenvolvimento deste trabalho. Em primeiro lugar será apresentada uma breve contextualização da região estudada, seguida da das discussões sobre o inventário do Patrimônio Geológico do Município de Ubatuba. Segue-se uma breve análise sobre os métodos de quantificação dos geossítios e, em seguida, a discussão dos resultados da quantificação e a conclusão desta etapa do trabalho. Posteriormente, apresentam-se algumas propostas para valorização e divulgação dos geossítios que se destacaram por apresentar um grande potencial turístico e, finalmente, as conclusões gerais e as perspectivas para estudos futuros na região enfocada.

\subsection{O Município de Ubatuba: contextualização da área}

O município de Ubatuba, situado no litoral norte do estado de São Paulo localiza-se a $250 \mathrm{~km}$ da capital. $\mathrm{Na}$ área que corresponde ao litoral, limita-se com os municípios de Caraguatatuba, ao sul e Parati, Rio de Janeiro, ao norte.

A geodiversidade e a biodiversidade local formam um ambiente com exuberantes paisagens, constituídas principalmente por praias, costões rochosos e a Mata Atlântica que encobre a maior parte das escarpas da Serra do Mar. Por este motivo, Ubatuba representa um dos principais destinos turísticos do litoral norte paulista.

Com o intuito de preservar tal beleza, principalmente no que diz respeito à biodiversidade, atualmente, existem em Ubatuba três importantes Unidades de Conservação: o núcleo Picinguaba do Parque Estadual da Serra do Mar, o Parque Estadual da llha Anchieta e a APA Marinha do litoral norte do estado de São Paulo.

Estas UC estão enquadradas nas diferentes categorias de manejo do SNUC. O Parque Estadual da llha Anchieta e o Núcleo Picinguaba do PESM se enquadram no grupo UC de Proteção Integral cuja categoria de manejo é Parque Nacional (PARNA). A APA marinha do Litoral norte é uma UC de Uso Sustentável cujo 
principal objetivo de criação é ordenar e proteger os recursos naturais da região e formar uma "zona de proteção" ao redor dos parques estaduais.

A gestão destas UC é de responsabilidade da Fundação para a Conservação e a Produção Florestal do estado de São Paulo. A mesma instituição é responsável pela elaboração do Plano de Manejo, documento que define os objetivos e tipos de uso cada Unidade de Conservação, de acordo com o enquadramento legal. No âmbito deste trabalho, os parques estaduais (PESM e PEIA) se enquadram na classe 2, cujo uso permitido é a prática do turismo em contato com a natureza. A APA marinha se enquadra na classe 6 , constituídas de locais com terrenos públicos e privados, com a possibilidade de diversos tipos de uso, porém visando um ordenamento territorial sustentável.

A região estudada geologicamente se insere no contexto da Plataforma SulAmericana, mais especificamente em um dos orógenos da Província Mantiqueira - o orógeno Ribeira. Localmente, a área está inserida no Terreno Serra do Mar (Domínio Costeiro), um dos terrenos que convergiram durante a aglutinação do Supercontinente Gondwana durante o Neoproterozoico - Cambriano.

A geodiversidade de Ubatuba inclui, além das praias e costões rochosos, importantes registros da história geológica do sudeste brasileiro. Como exemplos, temos as rochas charnockíticas, cuja importância geológica se associa à fase de aglutinação do Gondwana e com importância histórica ligada ao período de extração da rocha que contribuiu para desenvolvimento socioeconômico do município durante a década de 80. A llha Anchieta, que constitui um dos registros mais importantes das últimas fases da Orogenia Búzios, último evento colisional antes da fragmentação do Supercontinente. Ademais, temos a Gruta que Chora, na Praia da Sununga, que ilustra tanto a fase de colisão quanto a fase de fragmentação do Gondwana. Além disso, a gruta é um local marcado fortemente pelas lendas e mitos contados pela população local, evidenciando o seu interesse histórico-cultural.

Neste contexto, surgiram as motivações para este estudo que permitiu ao longo de diversas etapas a realização do inventário do patrimônio geológico de Ubatuba, como forma de conhecer e divulgar e preservar esse patrimônio. 


\subsection{0 inventário do Patrimônio Geológico de Ubatuba}

A metodologia adotada para a conservação do patrimônio geológico de Ubatuba agrupa uma série de etapas sequenciais como estratégias de geoconservação, que incluem: inventário, quantificação, classificação, conservação, valorização e divulgação e monitoramento (BRILHA, 2005). Para efeito deste trabalho estas etapas foram aplicadas até a fase de classificação dos geossítios de modo adaptado para o contexto da região do litoral norte de São Paulo. As etapas de conservação, valorização e divulgação dos geossítios não foram aplicadas, porém, apresentaram-se algumas propostas que podem ser aplicadas em trabalhos futuros. para o desenvolvimento destas etapas.

A etapa de inventário foi precedida de um levantamento bibliográfico principalmente no âmbito da geologia para a identificação dos geossítios de maneira direcionada. Porém, devido ao relevo bastante descontínuo e à cobertura vegetal, majoritariamente pela Mata Atlântica, os acessos aos afloramentos são bastante restritos aos costões rochosos ao longo da zona costeira. Assim, como aponta Garcia $^{21}$ et al. (2014) as informações disponíveis sobre os aspectos geológicos no caso específico do litoral são bastante escassas e quase restritas ao caráter regional. Deste modo, optou-se por além do levantamento bibliográfico a partir de trabalhos acadêmicos, um levantamento bibliográfico por meio da comunicação oral com os professores e colegas dos programas de pós-graduação do Instituto de Geociências (IGc/USP).

Muitos pontos identificados preliminarmente como geossítios resultaram da comunicação oral com professores do IGc/USP. Estes pontos apresentam essencialmente o caráter cientifico dos locais, pois se constituem na maioria das vezes em locais alvos de suas pesquisas e atividades de campo dos cursos de graduação. Além disso, muitos pontos foram sugeridos pelos guias do PESM e PEIA, ao longo de trabalhos de campo, durante o percurso das trilhas dentro e fora dos limites dos parques e por moradores locais. A principal característica que estes

21 GARCIA, M.G.M; MARTINS, L.; DEL LAMA, E.A.; BOUROTTE, C. O inventário do patrimônio geológico da região costeira do estado de São Paulo: base metodológica, adaptações e considerações. Trabalho apresentado no $47^{\circ}$ Congresso Brasileiro de Geologia, Salvador, 21 a 26 set 2014. 
locais apresentam é beleza cênica, que despertou a curiosidade dos monitores ambientais e dos turistas que os visitam.

Estas caraterísticas também foram destacadas por Prochoroff (2014) durante o inventário do patrimônio geológico da llhabela, um dos municípios do litoral norte de São Paulo. A autora destaca ainda a dificuldade em comunicar-se com pesquisadores geólogos sobre consultas de locais de importância geológica, mas, com potencial turístico e de fácil acesso. Tal motivo deve-se ao fato destes profissionais, na maioria das vezes não estarem familiarizados com os conceitos de patrimônio geológico e geoturismo. Assim, estas consultas, para efeito deste trabalho quando direcionadas aos geocientistas foram indagadas como "locais de importância geológica" ou "locais onde se realizam atividades didáticas para os alunos de graduação em geologia". Quando indagadas aos monitores dos parques e moradores locais os termos usados foram principalmente "locais com elementos de destaque (diferentes, que causam impacto visual)".

Ao final desta etapa, foram visitados noventa pontos, os quais cinquenta e nove encontram-se nas trilhas ecoturísticas dentro e fora das $\mathrm{UC}$ e, trinta e um pontos fora de trilhas, os quais foram nomeados de PL. Dentre todos os pontos identificados dez foram destacados como geossítios. Os demais pontos e percursos das trilhas integram o banco de dados do Núcleo de Apoio à Pesquisa ao Patrimônio Geológico e Geoturismo (GeoHereditas). Estes pontos foram devidamente descritos e atualmente são alvos de diferentes projetos em fase de elaboração' como roteiros (geo) interpretativos utilizados nos cursos de "Introdução às Geociências" oferecidos aos guias e monitores ambientais nos diferentes núcleos administrativos das UC pelo GeoHereditas.

Esta etapa incluiu ainda pesquisas no âmbito conceitual sobre o trinômio: geodiversidade, patrimônio geológico e geoconservação, e sobre o contexto das Unidades de Conservação no estado de São Paulo. Este levantamento permitiu o contato com uma gama de pesquisas, diferentes conceitos e metodologia, e ampliação dos conhecimentos no âmbito legal sobre o Sistema Nacional de Unidades de Conservação. Além disso, forneceu uma base conceitual para e elaboração deste trabalho. 


\subsection{Os Geossítios inventariados}

O inventário do patrimônio geológico de Ubatuba apresentado neste trabalho é composto por dez geossítios. O contexto geológico (framework) definido para a realização do inventário nos remete ao contexto geológico da Plataforma SulAmericana. O principal aspecto de caráter geocientífico considerado é a amalgamação, a evolução e a fragmentação do Supercontinente Gondwana, que se constituem em eventos tectônicos importantes na história geológica da região. Porém, não se deixou de considerar os aspectos históricos, culturais e turísticos.

Os geossítios foram agrupados de acordo com o interesse geológico principal e associação com os eventos na história do Gondwana Ocidental. Assim, como mostra a tabela 7.3.1 os geossítios "Pedra do Sino de Ubatuba", "Charnockito Ubatuba", "Praia do Cedro" e "Ponta Aguda" foram agrupados com o interesse ígneo, metamórfico e tectônico e representam principalmente os eventos da fase de aglutinação do Supercontinente (Neoproterozoico-Cambriano). Os três primeiros podem ser utilizados para a realização de atividades turísticas e didáticas. Já o geossítio Ponta Aguda tem um grande potencial para a realização apenas de atividades didáticas.

O geossítio "Monzogranito Ilha Anchieta" tem interesse ígneo e tectônico, registra os estágios finais desta aglutinação. Pode ser utilizado para a realização de atividades cientificas, didáticas e turísticas.

O Geossítio "Gruta que Chora", na Praia da Sununga tem interesse ígneo e tectônico e representa tanto a fase de aglutinação quanto a fase de fragmentação do Supercontinente. Este geossítio, além dos importantes registros da história geológica regional, tem grande interesse histórico-cultural.

Os geossítios "Brecha magmática Ilha Anchieta", "Xenólitos do manto e cones de explosão" e "Pico do Corcovado" representam a fase de fragmentação do Gondwana (Jurássico-Cretáceo). Estes geossítios têm como interesse principal o tectônico. Os dois primeiros apresentam grande potencial para a realização de atividades didáticas e científicas, pois registram processos raros na região. O Pico do Corcovado tem grande interesse geomorfológico e uso essencialmente turístico.

Por último, no geossítio Mineração Itamambuca, embora o principal litotipo presente no afloramento (charnockito) tenha grande importância na história geológica enfocada, a principal justificativa para a inclusão deste geossítio no 


\section{inventario deve-se ao fato de a Praia de Itamambuca representar um importante ponto história de extração do "Granito Verde Ubatuba", pois, constituiu-se na maior pedreira do Município.}

\begin{tabular}{|c|c|c|c|c|}
\hline Geossítio & Contexto geológico & Tipos de interesse & Principais Processos Ilustrativos & Usos \\
\hline Charnockito Ubatuba & $\begin{array}{l}\text { Fase de aglutinação do } \\
\text { Supercontinente durante } \\
\text { o Neoproterozoico- } \\
\text { Cambriano }\end{array}$ & $\begin{array}{c}\text { Ígneo, Metamórfico e } \\
\text { Tectônico }\end{array}$ & $\begin{array}{l}\text { Estruturação da Faixa Ribeira, II } \\
\text { Estágio Colisional durante a } \\
\text { aglutinação do Gondwana. }\end{array}$ & $\begin{array}{c}\text { Científico, turístico } \\
\text { e didático }\end{array}$ \\
\hline Praia do Cedro do Sul & $\begin{array}{l}\text { Fase de aglutinação do } \\
\text { Supercontinente durante } \\
\text { o Neoproterozoico- } \\
\text { Cambriano }\end{array}$ & $\begin{array}{c}\text { Ígneo, Metamórfico e } \\
\text { Tectônico }\end{array}$ & $\begin{array}{l}\text { Efeito de descharnockitização, } \\
\text { Magmatismo básico (diques } \\
\text { lamprófiro); Processos de } \\
\text { intemperismo (esfoliação esferoidal). }\end{array}$ & $\begin{array}{c}\text { Científico, turístico } \\
\text { e didático }\end{array}$ \\
\hline Pedra do Sino de Ubatuba & $\begin{array}{l}\text { Fase de aglutinação do } \\
\text { Supercontinente durante } \\
\text { o Neoproterozoico- } \\
\text { Cambriano }\end{array}$ & $\begin{array}{c}\text { Ígneo, Metamórfico e } \\
\text { Tectônico }\end{array}$ & $\begin{array}{l}\text { Efeito de descharnockitização, } \\
\text { Processos de intemperismo } \\
\text { (esfoliação esferoidal) }\end{array}$ & $\begin{array}{c}\text { Científico, turístico } \\
\text { e didático }\end{array}$ \\
\hline Praia Ponta Aguda & $\begin{array}{l}\text { Fase de aglutinação do } \\
\text { Supercontinente durante } \\
\text { o Neoproterozoico- } \\
\text { Cambriano }\end{array}$ & $\begin{array}{c}\text { Ígneo, Metamórfico e } \\
\text { Tectônico }\end{array}$ & $\begin{array}{l}\text { Primeiro evento deformacional durante } \\
\text { o Neoproterozoico (595-565 Ma), } \\
\text { ilustrado pelas relações de intrusão. }\end{array}$ & Científico e didático \\
\hline Monzogranito llha Anchieta & $\begin{array}{l}\text { Registra os estágios } \\
\text { finais da aglutinação do } \\
\text { Supercontinente } \\
\text { Gondwana } \\
\end{array}$ & Ígneo e Tectônico & $\begin{array}{l}\text { Processos ígneos desenvolvidos em } \\
\text { uma câmara magmática; Orogenia } \\
\text { Búzios, o último evento antes da } \\
\text { abertura do Atlântico Sul. }\end{array}$ & $\begin{array}{c}\text { Científico, turístico } \\
\text { e didático }\end{array}$ \\
\hline Gruta que Chora & $\begin{array}{l}\text { Representa tanto a fase } \\
\text { de aglutinação quanto à } \\
\text { fase de fragmentação do } \\
\text { Supercontinente. }\end{array}$ & Ígneo e Tectônico & $\begin{array}{l}\text { Relações de contato entre as rochas } \\
\text { (fase e aglutinação do Gondwana), } \\
\text { Gruta que Chora (processos } \\
\text { extensionais relacionados com a } \\
\text { fragmentação do Gondwana) }\end{array}$ & $\begin{array}{c}\text { Científico, turístico } \\
\text { e didático }\end{array}$ \\
\hline $\begin{array}{l}\text { Brecha Magmática llha } \\
\text { Anchieta }\end{array}$ & $\begin{array}{l}\text { Representam a fase de } \\
\text { fragmentação do } \\
\text { Gondwana, no Jurássico- } \\
\text { Cretáceo }\end{array}$ & Tectônico & $\begin{array}{l}\text { llustra os eventos magmáticos de } \\
\text { derrames basálticos e alcalinos que } \\
\text { resultaram na composição do Enxame } \\
\text { de Diques da Serra do Mar durante o } \\
\text { Cretáceo }(\sim 140-134 \mathrm{Ma})\end{array}$ & Científico e didático \\
\hline $\begin{array}{l}\text { Xenólitos do Manto e } \\
\text { Cones de Explosão }\end{array}$ & $\begin{array}{l}\text { Representam a fase de } \\
\text { fragmentação do } \\
\text { Gondwana, no Jurássico- } \\
\text { Cretáceo }\end{array}$ & Tectônico & \begin{tabular}{|l} 
Ilustra importantes e raros registros do \\
vulcanismo associados à \\
fragmentação do supercontinente \\
Gondwana no Cretáceo Inferior (132 \\
Ma) (colocação de diques, ocorrência \\
de xenólitos e cones de explosão).
\end{tabular} & Científico e didático \\
\hline Pico do Corcovado & $\begin{array}{l}\text { Representam a fase de } \\
\text { fragmentação do } \\
\text { Gondwana, no Jurássico- } \\
\text { Cretáceo }\end{array}$ & Geomorfológico & $\begin{array}{l}\text { Feições geomorfológicas do litoral: } \\
\text { evolução da Serra do Mar e Planície } \\
\text { Costeira }\end{array}$ & $\begin{array}{l}\text { Científico, turístico } \\
\text { e Geomorfológico }\end{array}$ \\
\hline Pedreira Itamambuca & $\begin{array}{l}\text { Fase de aglutinação do } \\
\text { Supercontinente durante } \\
\text { o Neoproterozoico- } \\
\text { Cambriano }\end{array}$ & Histórico-cultural & $\begin{array}{l}\text { Retrata o histórico da exploração do } \\
\text { charnockito Ubatuba, como rocha } \\
\text { ornamental durante a década de } 80 .\end{array}$ & $\begin{array}{c}\text { Cinetífico, turístico } \\
\text { e didático }\end{array}$ \\
\hline
\end{tabular}

Tabela 7.3.1 - Geossítios inventariados em Ubatuba, o contexto geológico, principais tipos de interesse e usos potenciais. 


\subsection{Etapa de quantificação dos geossítios}

A quantificação de relevância dos geossítios de Ubatuba permitiu a seriação e a classificação dos geossítios a serem submetidos às etapas subsequentes das estratégias de geoconservação. Durante este etapa optou-se pelo uso de três métodos distintos como exercício e aplicação e comparação entre os diferentes parâmetros e critérios que os compõem.

Além disso, o processo de quantificação contribuirá para a comparação entre os geossítios inventariados nos demais municípios do litoral norte do estado de São Paulo (Caraguatatuba (ARRUDA, 2013) ${ }^{22}$, São Sebastião (REVERTE, 2014) e Ilhabela (PROCHOROFF, 2014)), que juntos compõem o projeto de pesquisa "Roteiro Geoturístico do Litoral norte de São Paulo"23.

Para quantificação dos geossítios optou-se pelo uso do método de Brilha (2005) por se tratar de um método tradicional de quantificação de relevância de geossítios e constituir as bases para o desenvolvimento da "ficha" de quantificação adotada pela CPRM na plataforma GEOSSIT. Posteriormente os geossítios inventariados foram quantificados por dois métodos nacionais: o GEOSSIT (2014) e o método de Pereira (2010), que destaca-se por considerar os aspectos turísticos em uma categoria específica durante o processo de quantificação.

A seguir, serão apresentadas as adaptações necessárias para a aplicação dos métodos na região, seguidas das dificuldades encontradas durante esta etapa do trabalho.

\footnotetext{
${ }^{22}$ ARRUDA, K.E.C. A Geodiversidade do Litoral Norte de São Paulo. Doutorado em andamento (início: 2013).

${ }^{23}$ O patrimônio geológico do litoral norte do estado de SP: proposta de geoconservação. Projeto FAPESP, coordenadora: Profa. Dra. Maria da Glória Motta Garcia. Este projeto relaciona-se à organização do Roteiro Geoturístico incluindo os municípios do litoral norte do estado de São Paulo (Ubatuba, São Sebastião, Ilhabela e Caraguatatuba) com indicações dos principais geossítios, suas características geológicas e demais informações de interesse (GeoHereditas, 2014).
} 


\subsubsection{Método de Brilha (2005)}

O método de Brilha (2005) é composto por 22 parâmetros agrupados em três categorias: (i) características intrínsecas (A) que reúne nove parâmetros, (ii) o uso potencial $(B)$ reúne sete parâmetros e (iii) a necessidade de proteção $(C)$ reúne seis parâmetros. A cada parâmetro são atribuídas notas que variam de 1 a 5 para alguns deles e 1, 3 ou 5 para outros. Posteriormente é calculado o valor de relevância (Q) para cada geossítio. Os geossítios que apresentarem maior valor de $Q$ apresentam maior urgência em serem submetidos a estratégias de geoconservação.

$\mathrm{Na}$ categoria A (características intrínsecas), o parâmetro A3 (grau de conhecimento científico) não comtempla os Trabalhos de Conclusão de Curso (TCC) ou Trabalho Final de Graduação (TF) e os trabalhos apresentados em congressos nacionais e internacionais. Durante a etapa de levantamento bibliográfico, no que diz respeito aos trabalhos de conclusão de curso, optou-se por considerar estes trabalhos como publicações inéditas. Tal motivo deve-se ao fato de se tratar de trabalhos que, em geral, são requeridos com alto nível de exigência acadêmica e resultados consistentes que, obrigatoriamente, foram submetidos a bancas examinadoras no momento de apresentação ao departamento responsável da universidade de origem.

Quanto aos trabalhos apresentados em congressos e simpósio nacionais e internacionais, optou-se por considera-los, por se tratar de trabalhos resultantes de pesquisas acadêmicas que muitas vezes ainda estão em andamento ou que aparecem como artigos elaborados a partir de dissertações e teses de mestrado e doutorado.

Na categoria B (uso potencial) o parâmetro B1 (possibilidade de realizar as atividades propostas) sugere a opção realizar atividades turísticas junto às atividades didáticas e científicas. Cabe ressaltar que este método prevê o inventário de uma dada região essencialmente de cunho científico, portanto o valor turístico de dados locais pode ser aferido na opção (1) "é possível realizar outros tipos de atividades", contudo as atividades turísticas não são tidas com prioridades.

O parâmetro B4 (acessibilidade), não apresenta em nenhuma das opções percursos de trilhas ecoturísticas. Como aqui já apresentado, no caso específico de 
toda a região do litoral norte do estado de São Paulo o acesso aos afloramentos é bastante restrito, limitando-se a zona costeira. Os demais afloramentos encontramse em locais que muitas vezes são acessados apenas pelo percurso de longas trilhas na Mata Atlântica ou de barco, como os geossítios Monzogranito Ilha Anchieta e Brecha Magmática, localizados no PEIA. Uma alternativa adotada para casos como estes foi atribuir a estes locais a opção (1), localizados a mais de $1 \mathrm{~km}$ de estradas utilizáveis por automóveis.

Para parâmetro B6 (população a ser beneficiada com a utilização do geossítio) considerou-se para os locais próximos a centros urbanos a opção (3) população entre 10.000 e 25.000 habitantes em um raio de $25 \mathrm{Km}$ e para locais mais afastados, por exemplos em trilhas, a opção (2) população entre 5.000 e 10.000 . Estes dados foram estimados a partir dos dados obtidos pelo IBGE em 2010 para a população total do município, calculados em 78.801 habitantes. Cabe ressaltar que a população estimada neste parâmetro considerou-se apenas a população residente no município.

Quanto ao parâmetro B7 (condições socioeconômicas), tomou-se como fonte o Atlas do Desenvolvimento Humano Brasil, uma plataforma de consulta ao Índice de Desenvolvimento Humano Municipal - IDHM - de 5.565 municípios brasileiros, com dados extraídos dos Censos Demográficos de 1991, 2000 e 2010 do IBGE. De acordo com a plataforma o IDHM do município de São Paulo é de 0,783 e o de Ubatuba é de 0,751 . Portanto para todos os geossítios em B7 foram atribuídos à opção (1) "níveis de IDH inferiores à média estadual".

Finalmente, na categoria C (necessidade de proteção) o parâmetro C2 (situação atual) apresenta as opções “(5) geossítio sem qualquer proteção legal”, "(3) geossítios incluídos em área de proteção legal (Parque/APA)" e "(1) geossítios incluídos em Unidade de conservação já implantada". Para efeito deste trabalho, considerou-se a opção (3) como (1). Isso porque quando transpostas à realidade brasileira, tanto os Parques (nacionais e estaduais) quanto as APAs são apenas categorias distintas dentro do sistema de Unidade de Conservação. 


\subsubsection{Método GEOSSIT (2014)}

O GEOSSIT é uma plataforma para o cadastro, quantificação e valoração de geossítios por meio de uma base de dados do Sistema GEOBANK da CPRM. Esta plataforma agrupa uma série de parâmetros compreendidos em sete etapas: identificação do geossítio, enquadramento geológico, caracterização geológica, feições de relevo, interesse, conservação e quantificação de geossítios. Neste trabalho foi testada apenas a etapa de quantificação dos geossítios.

A quantificação dos geossítios pelo GEOSSIT baseia-se na reunião de duas metodologias distintas, a de Brilha (2005) e na metodologia de Garcia-Cortés \& Urquí (2009). Os critérios de quantificação foram agrupados em quatro categorias: (i) Vulnerabilidade, que reúne 10 critérios adaptados de Garcia-Cortés \& Urquí (2009), (ii) Características Intrínsecas sistematizadas por Brilha (2005) adicionada de A10 (utilização da imagem na divulgação turística), (iii) Uso Potencial adicionada dos parâmetros B8 (utilização didática) e B9 (conteúdo divulgativo), (iv) Necessidade de Proteção, somado o parâmetro C7 (proximidade de áreas recreativas).

A partir dos valores obtidos nas categorias A, B e C calcula-se o tipo de interesse: didático (Id), científico (Ic) e turístico (It) para cada geossítio. Os resultados obtidos pelos diferentes tipos de interesse gera um Índice global (Ig). Ao final, calcula-se a Prioridade de Proteção (PP) $(\mathrm{lg}+\mathrm{V})$ que determina a ordem de intervenção para cada geossítio em termos de proteção.

Na categoria Vulnerabilidade (V) existem três parâmetros que se repetem na categoria C. São eles: ameaças antrópicas, interesse para exploração mineral e proximidades de áreas recreativas (agressão potencial). Na categoria $\mathrm{C}$ estes parâmetros aparecem como: C3 (interesse para exploração mineral), C6 (fragilidade perante a ação humana) e C7 (proximidade de áreas recreativas). Nota-se que os parâmetros são computados duas vezes e, em $\mathrm{V}$ aparecem com pesos maiores: ameaças antrópicas e interesse de exploração mineral $15 \mathrm{e} \mathrm{em}$ proximidade de áreas recreativas tem peso 5. Portanto, ao final da quantificação, alguns geossítios podem ser supervalorizados em relação a outros, como por exemplo os geossítios que apresentarem grande interesse de exploração mineral, como o caso do 
geossítio Pedreira Itamambuca, que aparece em primeiro lugar no ranking de prioridade de proteção $(V=275)$, segundo este método.

No parâmetro "regime de proteção" as opções apresentadas são: (5) "locais sem algum tipo de proteção", (3) "locais situados em solo rural preservado de sua transformação pela urbanização" e (1) locais "com figura de proteção, porém não sujeito a plano de ordenamento sem vigilância. Também bens de interesse cultural em razão do seu conteúdo paleontológico e arqueológico". Entende-se que os locais sem qualquer tipo de proteção encontram-se mais vulneráveis que os locais que apresentam elementos de interesse arqueológico e paleontológico, pois, estes já se encontram amparados no âmbito legal pela Constituição Federal de 1988, Art. 216 que rege a proteção do Patrimônio Cultural brasileiro (BRASIL, 2014). Porém, no escopo deste trabalho para este parâmetro nenhuma das alternativas contemplam a área alvo e, portanto, não se aplicam.

No parâmetro A3 (grau de conhecimento científico) a adaptação feita a partir do método de Brilha (2005) apresenta seis opções, que contemplam os trabalhos apresentados em eventos como resumos de congressos, simpósios ou em painéis interpretativos. Porém os TF ou TCC ainda não são contemplados, assim, estes foram considerados mais uma vez como publicações inéditas na opção "descrição contemplada em dissertações de mestrado ou como artigos em revista nacional com corpo editorial".

Ainda na categoria A, no parâmetro A4 (utilidade como modelo de ilustrações de processos geológicos), são apresentadas mais opções que variam de "não se aplica" a "muito útil", possibilitando que esta análise seja feita mais detalhadamente. O mesmo ocorre em A8 (associação com elementos naturais), em que as opções permitem um nível de detalhamento bastante específico como a presença de espécies endêmicas em dada região. No caso da região estudada esta informação é extremamente importante, por se tratar do bioma Mata Atlântica, cuja fauna e flora são elementos de grande interesse. Assim, todos os geossítios puderam ser analisados sem grandes dificuldades.

Quanto à categoria $\mathrm{B}$, as mesmas adaptações feitas em B1, B4, B6 e B7 para a aplicação do método de Brilha (2005) foram consideradas para a aplicação deste método. Contudo, no parâmetro B9 (conteúdo divulgativo), a melhor alternativa que 
se aplica à região de estudo é "utilizado para ilustrar de maneira clara a grupos de certo nível de conhecimento técnico".

No que diz respeito à categoria $\mathrm{C}$, no parâmetro $\mathrm{C} 2$ (situação atual) a adaptação feita pela CPRM condiz exatamente com a realidade brasileira, pois, baseia-se no Sistema Nacional de Unidade de Conservação. Portanto, alguns geossítios foram enquadrados em "sítio tombado ou em unidade de Proteção Integral implantada" ou em "Unidade de Conservação de Uso Sustentável implantada".

Em contrapartida, em C4 (valor dos terrenos) as opções apresentadas não contemplam os geossítios Pico do Corcovado, Monzogranito llha Anchieta e Brecha Magmática Ilha Anchieta, isso porque não se pode atribuir valor aos terrenos inseridos em Unidades de Conservação. Como alternativa, para estes geossítios foram atribuídos os menores valores possíveis, "menor que dez reais o metro quadrado". Para os demais geossítios, os valores foram calculados a partir de dados obtidos por diferentes consultas em sites regionais.

Finalmente, em C5 (regime de propriedade) em alguns casos, como o geossítio Pedra do Sino, o acesso é feito por propriedade privada, porém, o geossítio em si, está localizado na praia, inserido na APA do litoral norte de São Paulo, portanto, bem pertencente à União. Assim, em casos como estes também se considerou a opção "terrenos predominantemente pertencentes ao estado".

\subsubsection{Método de Pereira (2010)}

O método de Pereira (2010) reúne um conjunto de vinte parâmetros compilados a partir de metodologias preexistentes e outros elaborados pelo próprio autor. Estes parâmetros foram agrupados em 4 categorias: (i) Valor intrínseco (Vi), (ii) Valor Científico (Vci), (iii) Valor Turístico (Vtur) e (iv) Valor de Uso/Gestão. Os valores atribuídos a cada parâmetro, diferente dos dois métodos testados anteriormente varia entre 0 e 4 . 
A partir dos resultados obtidos em cada categoria são calculados o Valor de Uso Científico (VUC), Valor de Uso Turístico, Valor de Conservação (VC) e o Ranking de Relevância $(\mathrm{R})$ do conjunto de geossítios que permite realizar a seriação dos geossítios de acordo com o tipo de uso e define a prioridade de proteger o local.

Na categoria Valor científico (Vci) em B1 (objeto de referências bibliográficas) ocorre o mesmo problema que nos métodos anteriores, trabalhos apresentados em congressos e simpósios e TF ou TCC não aparecem em nenhuma das opções. Porém, como uma alternativa, podem ser enquadrados na opção (3) citados em uma tese ou em outro tipo de publicação acadêmica. Um aspecto interessante a se considerar sobre este parâmetro são as opções (1) e (2) consideram como referências bibliográficas citações dos locais identificados como geossítios em relatórios técnicos e Plano de Manejo.

Ainda em Vci, para os parâmetros B3 (diversidade de interesses/ temáticas associadas) e B4 (relevância didática), se considerou como tipos de interesse geocientífico apenas aqueles os quais os geossítios haviam sido agrupados anteriormente (ígneo, metamórfico e tectônico; ígneo e tectônico; geomorfológico e histórico-cultural). Para o geossítio Pedreira Itamambuca, embora a rocha tenha interesse tectônico, ígneo e metamórfico, considerou-se para os parâmetros B3 e B4 apenas o interesse é histórico-cultural, que justifica a inclusão do geossítio no inventário.

Na categoria Vtur, em C1 (aspecto estético), a avaliação do geossítio torna-se extremamente subjetiva, como aponta o próprio autor, pois, depende única e exclusivamente do sentimento do observado. Nesse sentido, para os geossítios inventariados no presente trabalho, a fim de "minimizar" tal subjetividade exceto o geossítio Pico do Corcovado, o qual apresenta incomparável beleza cênica proporcionada pela ampla vista do litoral, os demais geossítios foram enquadrados na opção (2) geossítio inserido em local aprazível dotado de algum apelo estético.

Em C2 (acessibilidade) a maioria das opções (0) e (1) prevê o acesso aos geossítios pelo percurso de trilhas, nas opções (3) e (4) é previsto o acesso por trilhas e estradas asfaltadas ou não asfaltadas. Neste quesito, dos três métodos testados este é o único que contempla a área enfocada. Isso se deve ao fato deste método ser concebido no contexto de uma UC, o Parque Nacional Chapada 
Diamantina - Bahia. Tal motivo, também se relaciona ao fato de considerar o Plano de Manejo como referências bibliográficas em B1.

O mesmo ocorre nos parâmetros C3 (presença de infraestrutura) C4 (existência de utilização em curso), C5 (presença de mecanismo de controle de visitante) que constituem importantes ferramentas das UC para o planejamento turístico.

Por último, cabe ressaltar que na categoria Vug, o parâmetro D3 (nível oficial de proteção) indica se o local está inserido em uma UC ou não. Este parâmetro se assemelha aos outros métodos em C2 (situação atual) e não ao parâmetro "regime de proteção" como em V, segundo a plataforma GEOSSIT.

\subsubsection{Resultados da quantificação}

Os resultados obtidos pelos três métodos de quantificação foram bem diferentes (Tabela 7.4.4.1). No método de Brilha (2005) a classificação final dos geossítios baseia-se no resultado de (Q). Segundo este método, os geossítios foram classificados na seguinte ordem: Monzogranito Ilha Anchieta, Brecha Magmática llha Anchieta que aparecem juntos na primeira posição, seguidos dos geossítios Gruta que Chora, Xenólitos do Manto e Cones de Explosão, Praia do Cedro do Sul, Pedra do Sino de Ubatuba e Pedreira Itamambuca, Pico do Corcovado, Charnockito Ubatuba e Praia da Ponta Aguda (Gráfico 7.4.4.1a). No GEOSSIT (2014) a classificação dos geossítios baseia-se na Prioridade de Proteção (PP), assim, os cálculos de quantificação dos geossítios os classificaram na seguinte ordem: Pedreira Itamambuca, Pedra do Sino de Ubatuba, Xenólitos do Manto e Cones de Explosão, Praia do Cedro do Sul, Charnockito Ubatuba, Gruta que Chora, Monzogranito Ilha Anchieta, Brecha Magmática Ilha Anchieta, Pico do Corcovado e Praia da Ponta Aguda (Gráfico 7.4.4.1b).

Finalmente no método de Pereira (2010), os geossítios são classificados segundo o Ranking de Relevância $(R)$, calculado a partir do valor de uso dos geossítios (VUC, VUT e VC). Deste modo, o ranking dos geossítios inventariados em Ubatuba foi calculado na seguinte ordem: Monzogranito llha Anchieta, Brecha 
Magmática Ilha Anchieta, Gruta que Chora, Charnockito Ubatuba, Pico do Corcovado, Pedreira Itamambuca, Pedra do Sino de Ubatuba, Praia do Cedro do Sul, Praia da Ponta Aguda e Xenólitos do Manto e Cones de Explosão (Gráfico 7.4.4.1c).

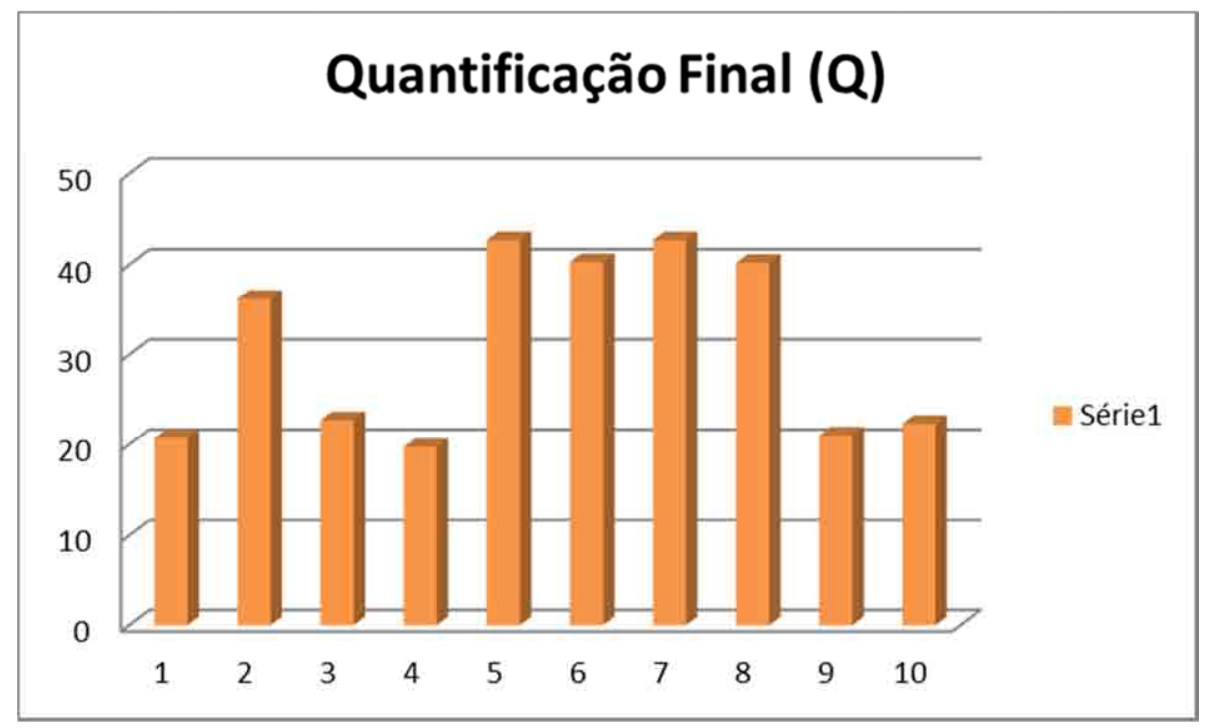

Gráfico 7.4.4.1. a - Resultado final da quantificação dos geossítios (Q) de Ubatuba pelo método de Brilha (2005). (1) Charnockito Ubatuba, (2) Praia do Cedro do Sul, (3) Pedra do Sino de Ubatuba, (4) Praia Ponta Aguda, (5) Monzogranito Ilha Anchieta, (6) Gruta que Chora, (7) Brecha Magmática Ilha Anchieta, (8) Xenólitos do Manto e Cones de Explosão, (9) Pico do Corcovado e (10) Pedreira Itamambuca.

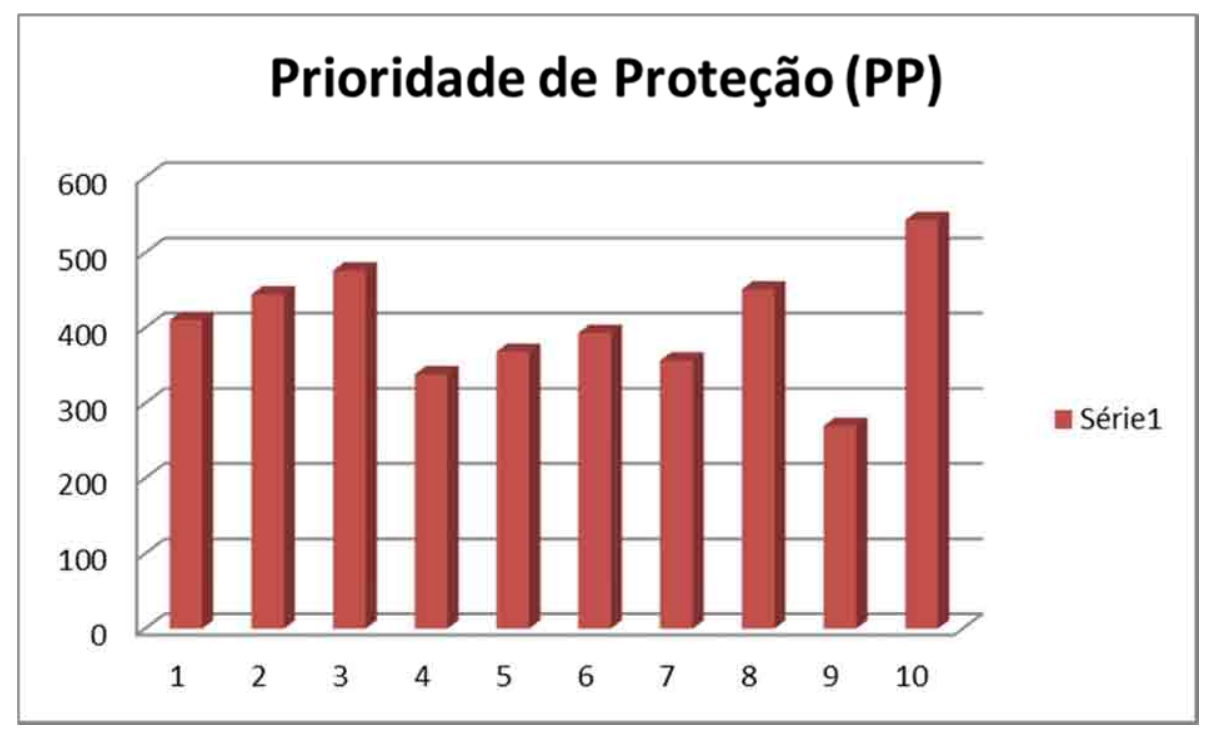

Gráfico 7.4.4.1. b - Prioridade de Proteção (PP) dos geossítios pelo método GEOSSIT (2014). (1) Charnockito Ubatuba, (2) Praia do Cedro do Sul, (3) Pedra do Sino de Ubatuba, (4) Praia Ponta Aguda, (5) Monzogranito Ilha Anchieta, (6) Gruta que Chora, (7) Brecha Magmática Ilha Anchieta, (8) Xenólitos do Manto e Cones de Explosão, (9) Pico do Corcovado e (10) Pedreira Itamambuca. 


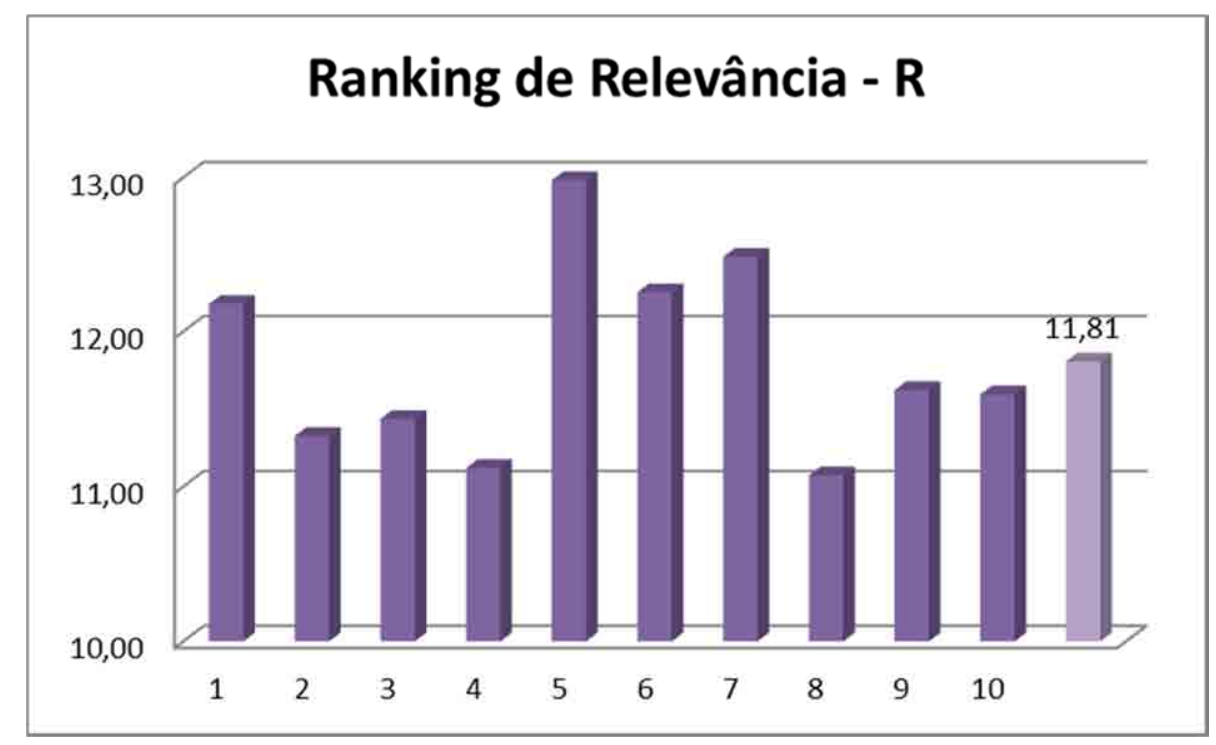

Gráfico 7.4.4.1. c - Ranking de Relevância (R) dos geossítios inventariados em Ubatuba, segundo método de Pereira (2010). (1) Charnockito Ubatuba, (2) Praia do Cedro do Sul, (3) Pedra do Sino de Ubatuba, (4) Praia Ponta Aguda, (5) Monzogranito Ilha Anchieta, (6) Gruta que Chora, (7) Brecha Magmática Ilha Anchieta, (8) Xenólitos do Manto e Cones de Explosão, (9) Pico do Corcovado e (10) Pedreira Itamambuca. Média de $(R)=11,81$.

\begin{tabular}{|c|c|c|c|}
\hline Posição & Método de Brilha (2005) & Método GEOSSIT (2014) & Método de Pereira (2010) \\
\hline \multirow{2}{*}{$1^{\circ}$} & Monzogranito Ilha Anchieta & \multirow{2}{*}{ Pedreira Itamambuca } & \multirow{2}{*}{ Monzogranito llha Anchieta } \\
\hline & Brecha Magmática Ilha Anchieta & & \\
\hline $2^{\circ}$ & Gruta que Chora & Pedra do Sino de Ubatuba & Brecha Magmática Ilha Anchieta \\
\hline $3^{\circ}$ & $\begin{array}{l}\text { Xenólitos do Manto e Cones de } \\
\text { Explosão }\end{array}$ & $\begin{array}{l}\text { Xenólitos do Manto e Cones de } \\
\text { Explosão }\end{array}$ & Gruta que Chora \\
\hline $4^{\circ}$ & Praia do Cedro do Sul & Praia do Cedro do Sul & Charnockito Ubatuba \\
\hline $5^{\circ}$ & Pedra do Sino de Ubatuba & Charnockito Ubatuba & Pico do Corcovado \\
\hline $6^{\circ}$ & Pedreira Itamambuca & Gruta que Chora & Pedreira Itamambuca \\
\hline $7^{\circ}$ & Pico do Corcovado & Monzogranito Ilha Anchieta & Pedra do Sino de Ubatuba \\
\hline $8^{\circ}$ & Charnockito Ubatuba & Brecha Magmática llha Anchieta & Praia do Cedro do Sul \\
\hline $9^{\circ}$ & Praia da Ponta Aguda & Pico do Corcovado & Praia da Ponta Aguda \\
\hline $10^{\circ}$ & & Praia da Ponta Aguda & $\begin{array}{l}\text { Xenólitos do Manto e Cones de } \\
\text { Explosão }\end{array}$ \\
\hline
\end{tabular}

Tabela 7.4.4.1. Comparação entre a seriação dos geossítios a partir dos resultados obtidos nos diferentes métodos de quantificação: à esquerda temos os resultados obtidos pelo método Brilha de (2005), ao centro os resultados obtidos pelo método GEOSSIT (2014) e a direita os resultados obtidos pelo método de Pereira (2010). 
Os três métodos aplicados consideram a classificação de relevância dos geossítio no âmbito internacional, nacional, regional ou local. No método de Brilha e no GEOSSIT, para esta classificação são analisados os parâmetros $A 1, A 3, A 6, A 9$, B1 e B2 e a satisfação das seguintes condições:

- A1 (abundância e raridade): obter valor maior ou igual a 3, ou seja, existir menos de 10 exemplos na área estudada (método de Brilha) ou menos de 15 exemplos (método GEOSSIT);

- A3 (grau de conhecimento científico): obter nota maior ou igual a 4, ou seja, no mínimo ser comtemplado em artigo de revista nacional ou estrangeira ou em capítulo de um livro no método de Brilha. No GEOSSIT aparecer pelo menos em mapeamentos regionais;

- A6 (localidade tipo): obter nota maior ou igual a 3, ser no mínimo reconhecido como localidade tipo-secundário

- A9 (estado de conservação): obter no mínimo nota 3, não haver comprometimento na observação das características essenciais do geossítio, mesmo que no local existam escavações ou construções;

- B1 (possibilidade de realizar atividades propostas): obter no mínimo nota 3, no geossítio deverá existir a possibilidade de realizar as atividades propostas de cunho cientifico ou pedagógicas;

- B2 (condições de observação): as condições de observações no geossítio devem ser no mínimo razoáveis, no mínimo nota 3.

Os resultados obtidos por estes dois métodos foram muito parecidos, o que se deve ao fato de, além dos parâmetros analisados para a classificação de relevâncias serem os mesmos, as opções apresentadas são muito parecidas; assim as notas obtidas por cada geossítio não variaram muito. Além disso, as adaptações feitas para os parâmetros A3 e B1 foram adotadas para a aplicação dos dois métodos.

Assim, no método de Brilha, os geossítios Charnockito Ubatuba, Pedra do Sino de Ubatuba, Praia da Ponta Aguda, Pico do Corcovado e Pedreira Itamambuca foram classificados com relevância regional ou local. No GEOSSIT os mesmos geossítios se classificam com relevância regional. Os geossítios Praia do Cedro do Sul, Monzogranito Ilha Anchieta, Brecha Magmática Ilha Anchieta, Xenólitos do 
manto e Cones de Explosão, no método de Brilha foram classificados de relevância internacional/nacional e de relevância internacional no GEOSSIT.

Apenas o geossítio Gruta que Chora obteve classificação de relevância diferente nos dois métodos. O parâmetro A3 (grau de conhecimento científico) foi determinante para a obtenção deste resultado. No método de Brilha a melhor opção em que o geossítio se enquadra é a opção (4) - "contemplado em artigo de revista nacional ou estrangeira, ou em capítulo de livro"; no GEOSSIT, a opção que melhor se enquadra é (2) - "descrição publicada em revista nacional ou estrangeira sem corpo editorial". Cabe ressaltar que a escolha destas opções justifica-se pelo fato do principal elemento de interesse que justifica a inclusão do geossítio neste inventário e o interesse secundário (histórico-cultural) são contemplados apenas em artigos científicos em revistas eletrônicas sem corpo editorial.

No método de Pereira, a classificação de relevância difere um pouco dos dois primeiros métodos. Neste, os geossítios são classificados a partir da análise do valor médio de $R$ (ranking de relevância) e dos parâmetros $A 2, A 3, B 1, B 2, C 2$ e $C 3$, satisfazendo as seguintes condições:

- A2 (abundância e raridade): os geossítios que obtiverem notas igual ou maior que 3, ou seja existir até 3 exemplares na região de estudo;

- A3 (integridade): geossítio com alguma deterioração, porém sem comprometer as condições de observação dos principais aspectos observados e com possibilidade de ser recuperado;

- B1 (grau de conhecimento científico): a nota do geossítio deverá ser no mínimo 2, citado em artigo de revista nacional e relatórios ou Plano de Manejo;

- B2 (representatividade de materiais e processos geológicos): abrigar registros de elementos ou processos, mas que não sejam utilizados como exemplos clássicos;

- C2 (acessibilidade): o acesso ao geossítio deverá ser no mínimo a partir de estradas não asfaltadas e trilhas com menos de 2 km de extensão;

- C3 (presença de infraestrutura): dotado de infraestrutura rudimentar, mas que sirva de apoio ao visitante. 
Os resultados obtidos neste trabalho a partir do método de Pereira permitiram a classificação de relevância dos geossítios em nacional para os geossítios Charnockito Ubatuba, Monzogranito Ilha Anchieta, Brecha Magmática Ilha Anchieta e Gruta que Chora. Os demais geossítios foram classificados com relevância regional: Praia do Cedro do Sul, Pedra do sino de Ubatuba, Praia da Ponta Aguda, Xenólitos do Manto e Cones de Explosão, Pico do Corcovado e Pedreira Itamambuca.

Neste método, nenhum geossítio foi classificado de âmbito internacional, porque os geossítios que obtiveram $\mathrm{R}>$ que o valor médio de relevância do conjunto de geossítios $(R=11,81)$ não atendem aos requisitos do conjunto de parâmetros analisados para esta classificação. No caso do geossítio Charnockito Ubatuba, a nota atribuída ao parâmetro A2 foi 0 , ou seja, existem mais de 10 exemplares na área de estudo. No Monzogranito Ilha Anchieta, as notas atribuídas para A2 (1) e C2 (1) não tingiram o mínimo necessário ( $A 2 \geq 3$ e $C 2 \geq 2$ ). O geossítio Brecha Magmática Ilha Anchieta não atingiu nota suficiente nos parâmetros C2 e C3 = 0 (C2 e C3 $\geq 2$ ). Por último, o geossítio Gruta que Chora somente no parâmetro C3 = 0 não alcançou nota suficiente. Cabe ressaltar que, segundo o próprio autor, este é o único parâmetro que não aparece na maioria das metodologias sistematizadas para a quantificação de geossítios; os demais representam parâmetros universais de grande importância para esta avaliação.

Comparando-se os resultados parciais (valores médios) atribuídos para cada categoria que compõem os métodos testados, nota-se que na categoria $A$ (características intrínsecas) nos métodos de Brilha e GEOSSIT as médias dos geossítios variam até 0,5 pontos para a maioria deles, contudo, nos geossítios Monzogranito Ilha Anchieta e Brecha Magmática Ilha Anchieta esta variação é um pouco maior 0,67. Isso ocorre principalmente pela inclusão do parâmetro A10 (utilização da imagem na divulgação turística) na plataforma GEOSSIT que contribuiu para a diminuição na média destes geossítios (Gráficos 4.4.1.2a/b).

No método de Pereira a categoria valor intrínseco (Vi) dos geossítios é composta por 4 parâmetros, dentre eles apenas dois (A1 e A3) aparecem na categoria A nos três métodos. Assim, as médias obtidas segundo este método são apresentadas no gráfico 4.4.1.2c. Os geossítios de ocorrência menos comum na 
área de estudo (exemplar único), sobrepuseram a média de Vi $(2,25)$ e ocupam as primeiras posições nesta categoria, são eles: Pedra do Sino de Ubatuba, Gruta que Chora, Brecha Magmática Ilha Anchieta e Xenólitos do Manto e Cones de Explosão.
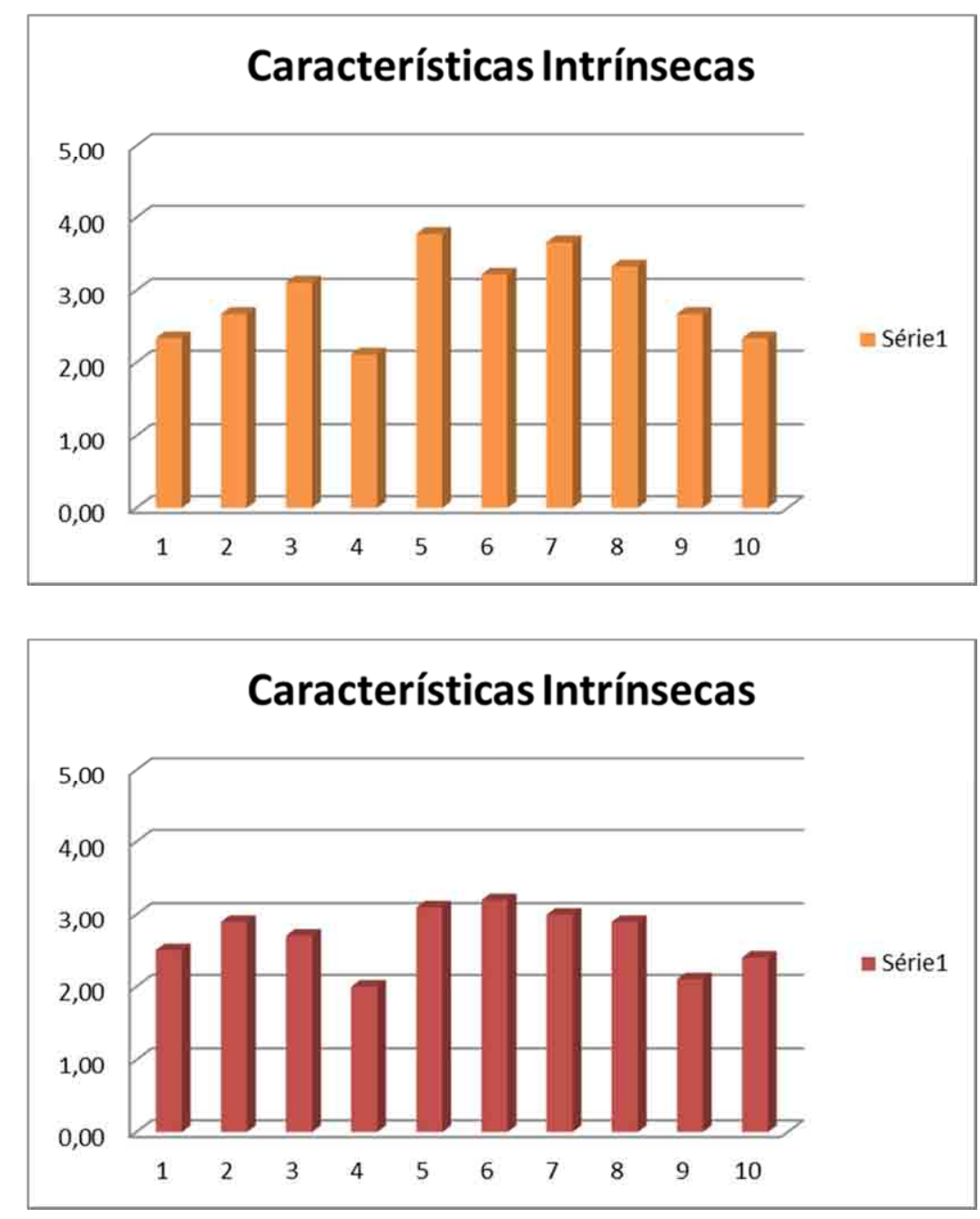

Gráfico 7.4.4.2. a - Resultados parciais para a categoria A (Características Intrínsecas), segundo método de Brilha (2005); b - Resultados parciais para a categoria A (Características Intrínsecas), segundo método GEOSSIT (2014). Série 1: (1) Charnockito Ubatuba, (2) Praia do Cedro do Sul, (3) Pedra do Sino de Ubatuba, (4) Praia Ponta Aguda, (5) Monzogranito Ilha Anchieta, (6) Gruta que Chora, (7) Brecha Magmática Ilha Anchieta, (8) Xenólitos do Manto e Cones de Explosão, (9) Pico do Corcovado e (10) Pedreira Itamambuca. Média de $\mathrm{Vi}=2,25$ pelo método Pereira. 


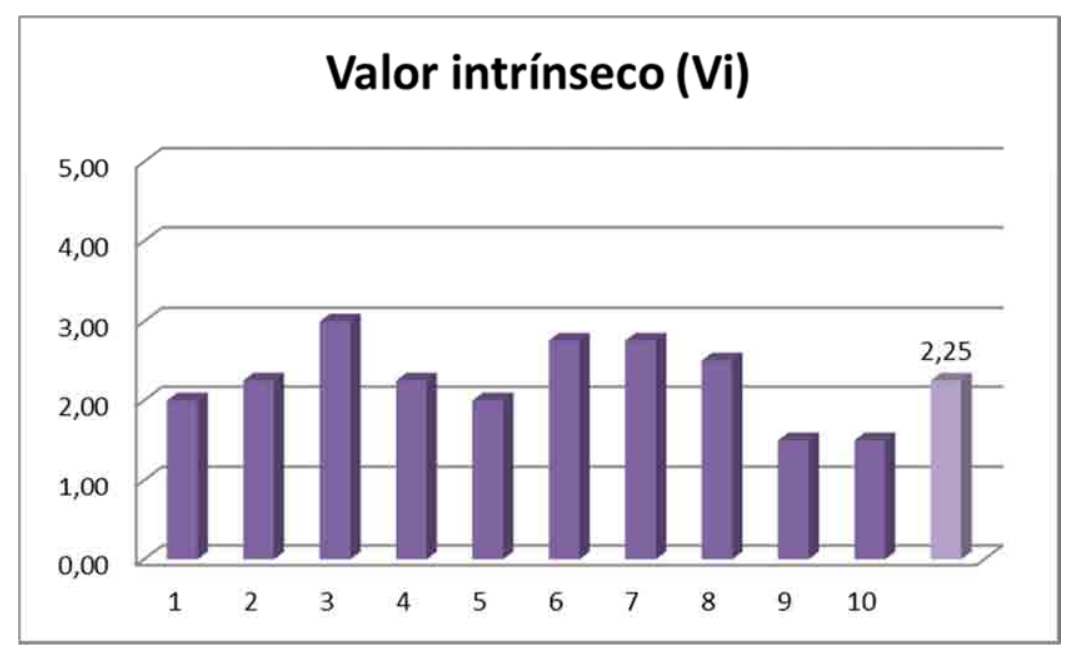

Gráfico 7.4.4.2. c) Resultado parcial para categoria valor intrínseco (Vi) pelo método de Pereira (2010). Série 1: (1) Charnockito Ubatuba, (2) Praia do Cedro do Sul, (3) Pedra do Sino de Ubatuba, (4) Praia Ponta Aguda, (5) Monzogranito Ilha Anchieta, (6) Gruta que Chora, (7) Brecha Magmática Ilha Anchieta, (8) Xenólitos do Manto e Cones de Explosão, (9) Pico do Corcovado e (10) Pedreira Itamambuca. Média de Vi = 2,25 pelo método Pereira.

Os gráficos 7.4.4.3a/b expressam os resultados obtidos na categoria B (uso potencial) pelos métodos de Brilha e GEOSSIT. Nota-se que os resultados obtidos pelo método de Brilha, comparados aos resultados pelo GEOSSIT, são maiores para todos os geossítios. Isso ocorre pela inclusão dos parâmetros B8 (utilização didática) e B9 (conteúdo divulgativo), que não integram a categoria B no método de Brilha.

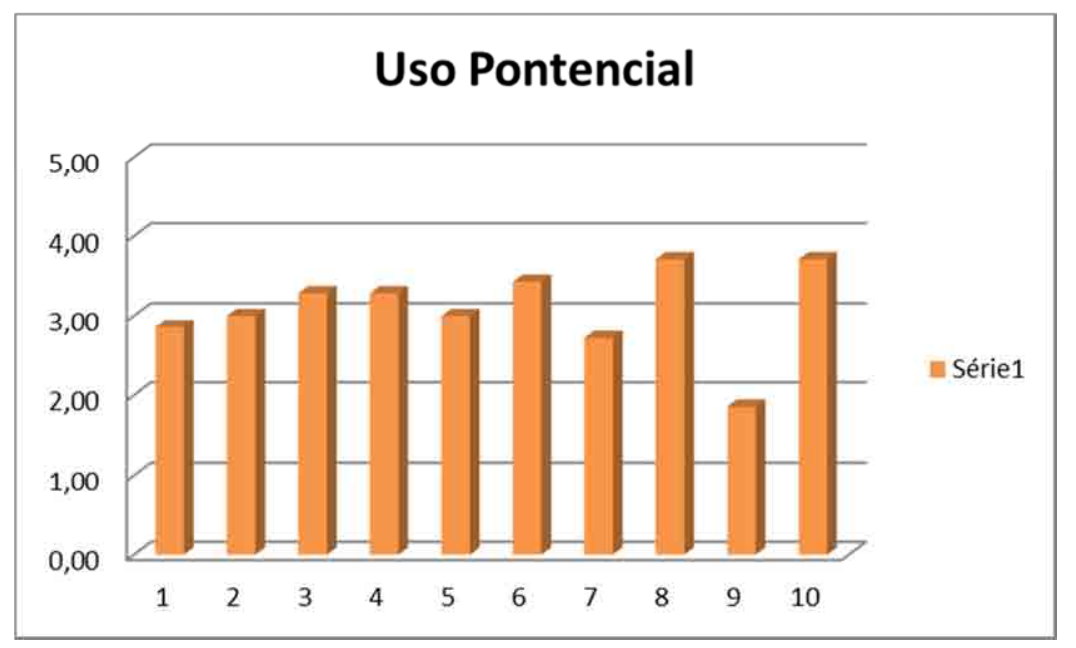

Gráfico 7.4.4.3. a - Resultado parcial para a categoria B (Uso Potencial), segundo método de Brilha (2005); (1) Charnockito Ubatuba, (2) Praia do Cedro do Sul, (3) Pedra do Sino de Ubatuba, (4) Praia Ponta Aguda, (5) Monzogranito Ilha Anchieta, (6) Gruta que Chora, (7) Brecha Magmática Ilha Anchieta, (8) Xenólitos do Manto e Cones de Explosão, (9) Pico do Corcovado e (10) Pedreira Itamambuca. 


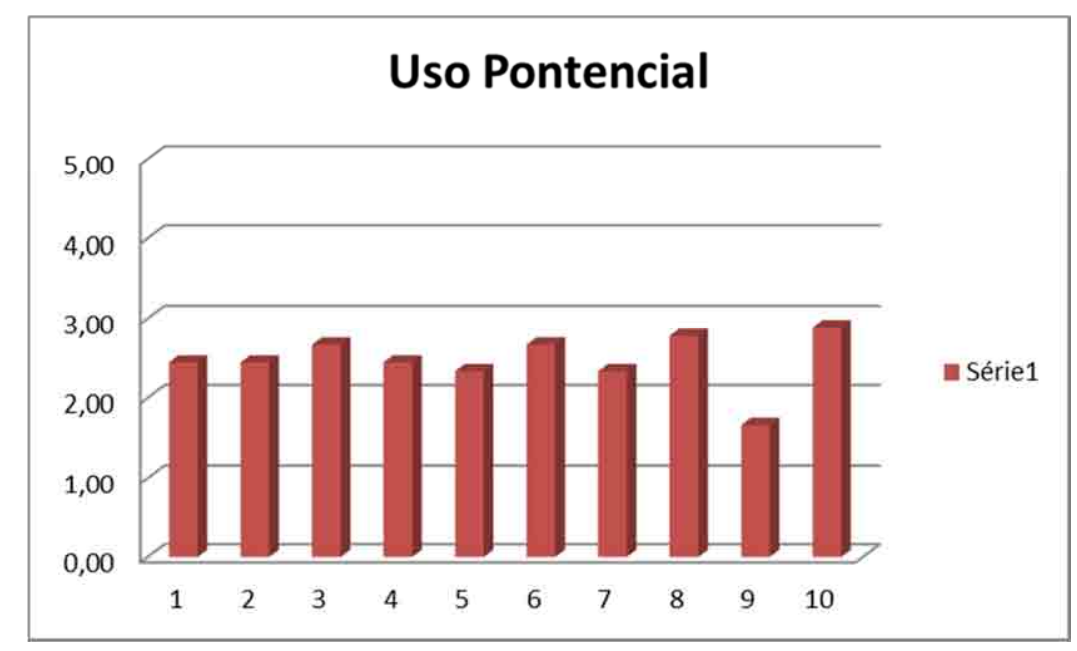

Gráfico 7.4.4.3. b - Resultado parcial para a categoria B (Uso Potencial), segundo método GEOSSIT (2014); (1) Charnockito Ubatuba, (2) Praia do Cedro do Sul, (3) Pedra do Sino de Ubatuba, (4) Praia Ponta Aguda, (5) Monzogranito Ilha Anchieta, (6) Gruta que Chora, (7) Brecha Magmática Ilha Anchieta, (8) Xenólitos do Manto e Cones de Explosão, (9) Pico do Corcovado e (10) Pedreira Itamambuca.

No método de Pereira o uso dos geossítios é avaliado na categoria Vug (uso/ gestão). Apenas dois parâmetros, D6 (população do núcleo urbano mais próximo) e D7 (condições socioeconômicas dos núcleos mais próximos) desta categoria também aparecem nos dois métodos anteriores. Mediante os resultados expressados no gráfico 7.4.4.3c, os geossítios Gruta que Chora, Pedreira Itamambuca, seguidos dos geossítios Charnockito Ubatuba e Monzogranito Ilha Anchieta, sobrepuseram a média de Vug $(2,46)$ e ocupam as primeiras posições. Estes geossítios são de grande interesse cultural e possuem interesse econômico não viável por se tratar de locais inseridos em UC, portanto, receberam maior pontuação nos parâmetros D1 (relevância cultural) e D2 (relevância econômica) colocando-os acima da média nesta categoria. 


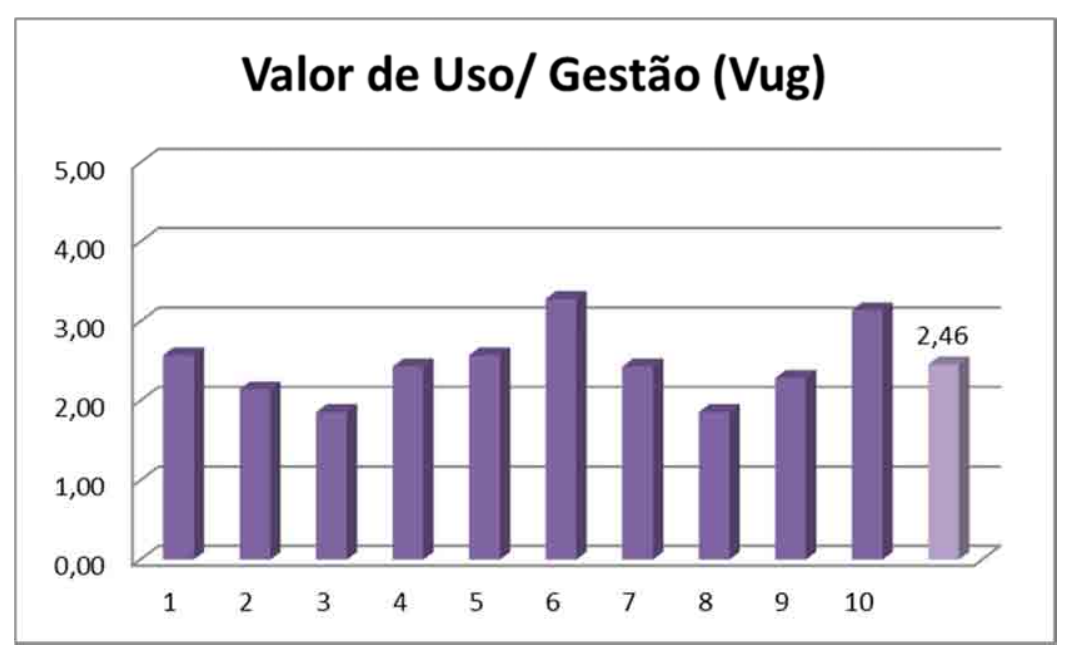

Gráfico 7.4.4.3. c - Resultado parciail para categoria valor de uso/gestão (Vug) pelo método de Pereira (2010). (1) Charnockito Ubatuba, (2) Praia do Cedro do Sul, (3) Pedra do Sino de Ubatuba, (4) Praia Ponta Aguda, (5) Monzogranito Ilha Anchieta, (6) Gruta que Chora, (7) Brecha Magmática Ilha Anchieta, (8) Xenólitos do Manto e Cones de Explosão, (9) Pico do Corcovado e (10) Pedreira Itamambuca. Médio de Vug = 2,46.

$\mathrm{Na}$ categoria $\mathrm{C}$ (necessidade de proteção) o resultado obtido pelo método de Brilha comparado aos resultados pelo GEOSSIT (Gráficos 7.4.4.5a/b), mostram que a diferença entre os valores de cada geossítio varia em média 0,5 pontos. No método de Brilha a maioria dos geossítios aparece com maiores notas, são eles: Charnockito Ubatuba, Pedra do Sino de Ubatuba, Praia do Cedro do Sul, Gruta que Chora, Xenólitos do Manto e Cones de Explosão e Pedreira Itamambuca. Os geossítios Praia da Ponta Aguda, Monzogranito Ilha Anchieta, Brecha Magmática Ilha Anchieta e Pico do Corcovado, no GEOSSIT, receberam maior pontuação. Isso ocorre em função das alternativas apresentadas no parâmetro C2 (situação atual), que melhor enquadrada os geossítios nas diferentes categorias de manejo das UC e pela inclusão do parâmetro C7 (proximidade de áreas recreativas) ao GEOSSIT que eleva também a pontuação destes geossítios. 

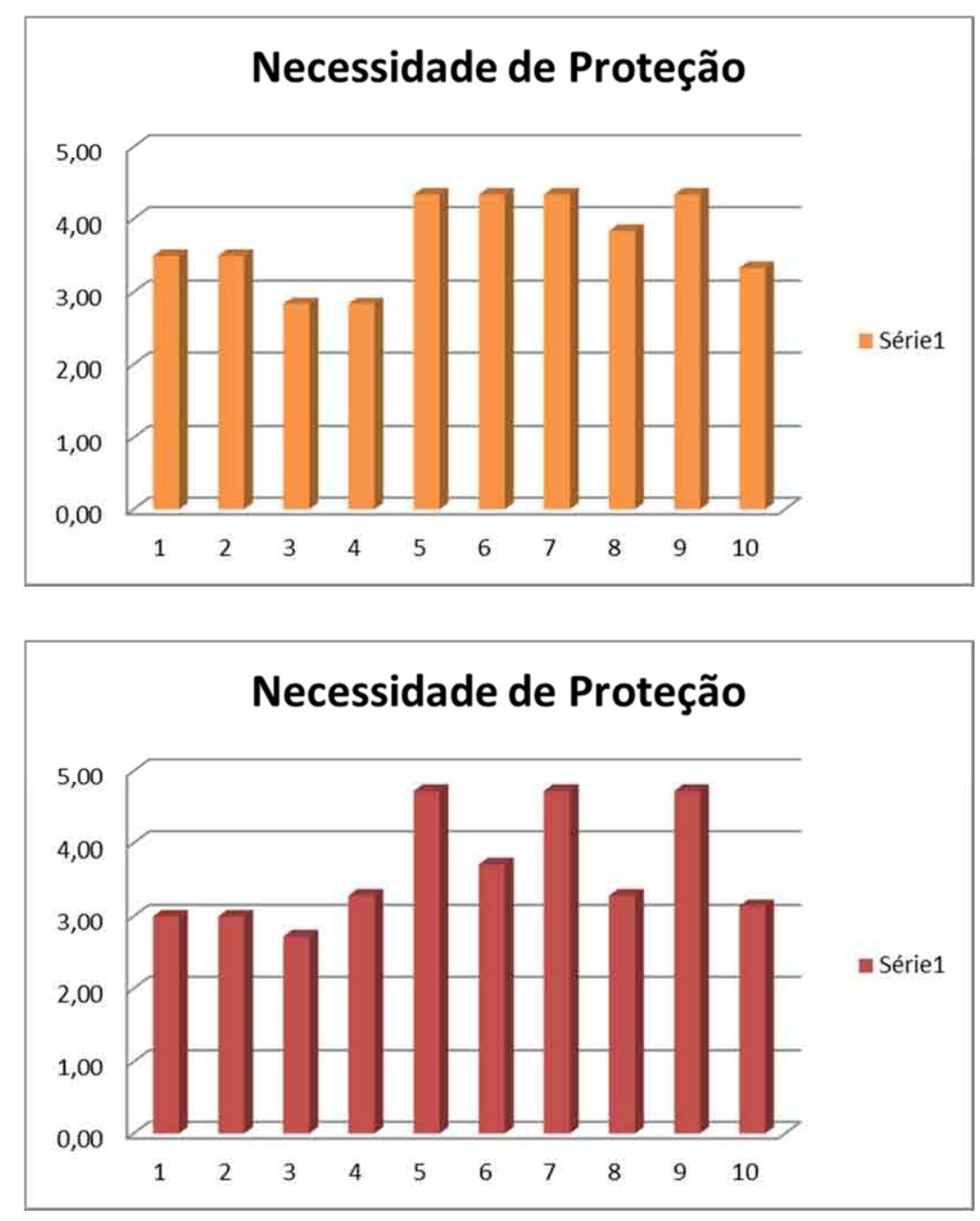

Gráfico 7.4.4.4. a - Resultados parciais para a categoria C (Necessidade de Proteção), segundo método de Brilha (2005); b - Resultados parciais para a categoria C (Necessidade de Proteção), segundo método GEOSSIT (2014). (1) Charnockito Ubatuba, (2) Praia do Cedro do Sul, (3) Pedra do Sino de Ubatuba, (4) Praia Ponta Aguda, (5) Monzogranito llha Anchieta, (6) Gruta que Chora, (7) Brecha Magmática Ilha Anchieta, (8) Xenólitos do Manto e Cones de Explosão, (9) Pico do Corcovado e (10) Pedreira Itamambuca.

Além das categorias A, B e C, o GEOSSIT é composto pela categoria Vulnerabilidade (V), advinda da metodoliga de García-Cortés \& Urquí (2009). Com base nos resultados obtidos para esta categoria, o geossítio Pedreira Itamambuca aparece com maior valor, o que contribuiu para que este geossítio apareça em primeiro lugar quando calculada a prioridade de proteção (PP) dos geossítios inventariados em Ubatuba. Isso ocorre, principalmente, pelo parâmetro "interesse para exploração mineral" que tem um peso muito alto processo de quantifição e aparece duplicado nesta metodologia (na categorias $\mathrm{V}$ e em C3). O mesmo ocorre para os geossítios Pedra do Sino de Ubatuba, que aparece na segunda posição na 
quantificação geral e Charnockito Ubatuba, que também teve sua pontuação elevada na categoria $\mathrm{V}$ e em C3 e aparece em quinto lugar.

Cabe ressaltar que, no método de Brilha, o cálculo da vulnerabilidade dos geossítios é feito na categoria $C$ (necessidade de proteção); já no método de Pereira os parâmetros que avaliam a vulnerabilidade dos geossítios estão dispostos nas categorias Vi e Vug.

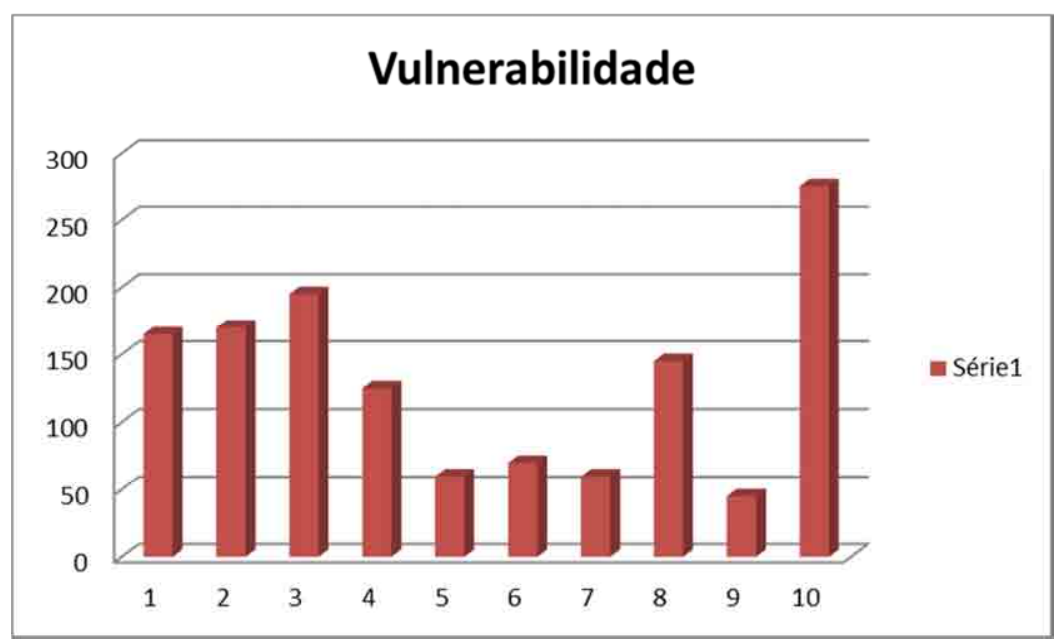

Gráfico 7.4.4.5 - Resultado parcial para a categoria Vulnerabilidade segundo método GEOSSIT (2014). (1) Charnockito Ubatuba, (2) Praia do Cedro do Sul, (3) Pedra do Sino de Ubatuba, (4) Praia Ponta Aguda, (5) Monzogranito Ilha Anchieta, (6) Gruta que Chora, (7) Brecha Magmática Ilha Anchieta, (8) Xenólitos do Manto e Cones de Explosão, (9) Pico do Corcovado e (10) Pedreira Itamambuca.

No método de Pereira, o valor científico dos geossítios é calculado na categoria Vci, composta por 4 parâmetros. Nos métodos de Brilha e GEOSSIT o valor científico dos geossítios é calculado nas categorias A e B. O gráfico 7.4.4.6a expressa os resultados obtidos para a categoria Vci, em que apenas os geossítios Charnockito Ubatuba, Monzogranito Ilha Anchieta, Brecha Magmática e Pedreira Itamambuca aparecem com valores acima da média de Vci $(2,78)$. Os três últimos, comparados ao método Brilha, ocupam posições muito parecidas no Ranking de Relevância (R): Monzogranito Ilha Anchieta, Brecha Magmática em primeiro lugar e Pedreira Itamambuca em sexto lugar. Neste método os mesmos aparecem, respectivamente, em primeiro e segundo lugar e igualmente em sexto lugar. Portanto, é evidente que embora este método tenha sido concebido no contexto das 
UC brasileiras e considere fortemente os aspectos turísticos de dada região, o principal caráter avaliado para a quantificação dos geossítios é o caráter científico.

No que diz respeito à categoria Vtur, ainda no método de Pereira, exceto pelo parâmetro C2 (acessibilidade) que também aparecem nos métodos anteriores, os demais parâmetros são exclusivos desta metodologia. Com base no gráfico 7.4.4.6b, os geossítios que se sobrepuseram à média do valor turístico são: Monzogranito llha Anchieta e Pico do Corcovado, que aparecem em primeiro lugar nesta categoria, e Charnockito Ubatuba, Pedra do Sino de Ubatuba. Os dois primeiros tiveram suas notas aumentadas principalmente pelos parâmetros C3 (acessibilidade), pois possuem infraestrutura rudimentar que serve apoio ao visitante e C4 (existência de utilização em curso), para os dois geossítios há controle sistemático de visitantes, pelos núcleos administrativos das UC as quais estão inseridos.

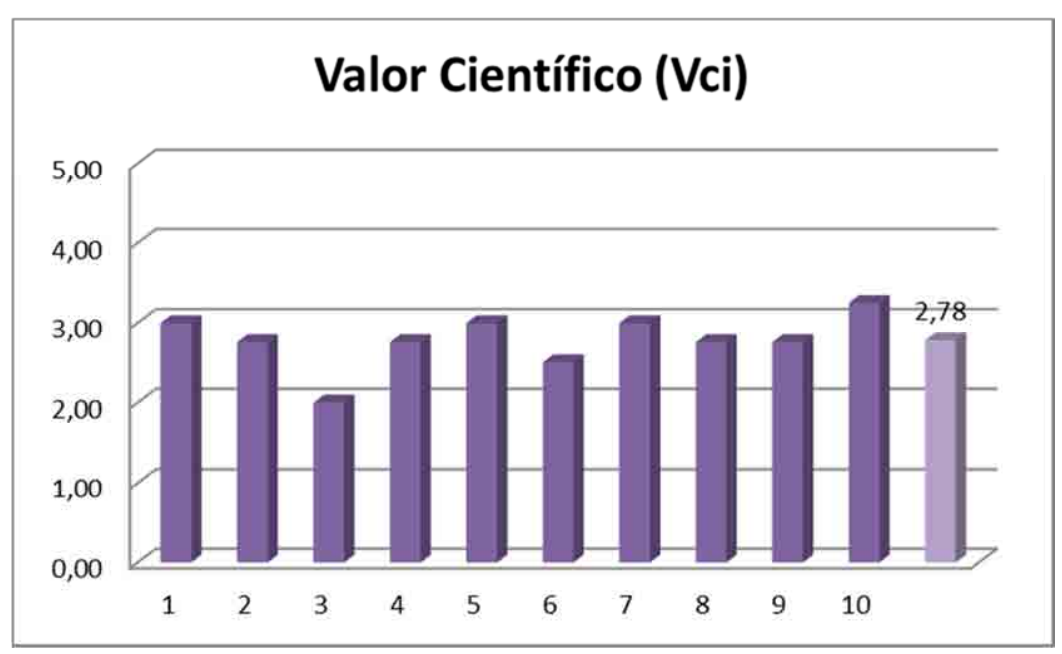

Gráfico 7.4.4.6 a - Resultado parcial para a categoria Valor científico (Vci) segundo método de Pereira (2010). (1) Charnockito Ubatuba, (2) Praia do Cedro do Sul, (3) Pedra do Sino de Ubatuba, (4) Praia Ponta Aguda, (5) Monzogranito Ilha Anchieta, (6) Gruta que Chora, (7) Brecha Magmática Ilha Anchieta, (8) Xenólitos do Manto e Cones de Explosão, (9) Pico do Corcovado e (10) Pedreira Itamambuca. Média de Vci = 2,78 e Vtur = 1,62. 


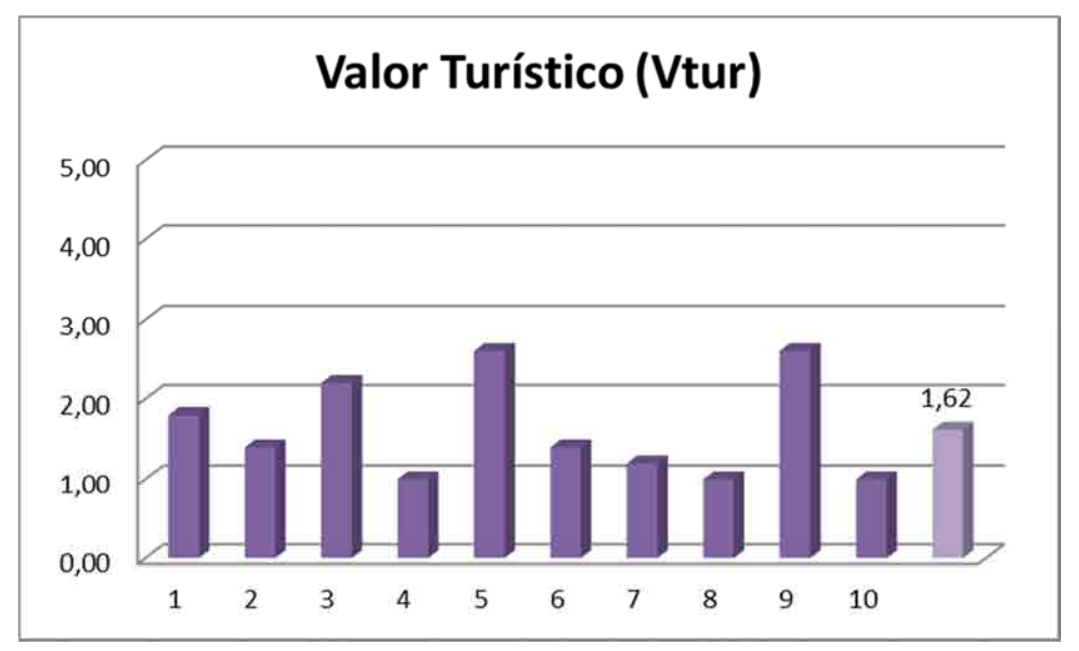

Gráfico 7.4.4.6 a/b - Resultado parcial para a categoria Valor Turístico (Vtur) segundo método de Pereira (2010). (1) Charnockito Ubatuba, (2) Praia do Cedro do Sul, (3) Pedra do Sino de Ubatuba, (4) Praia Ponta Aguda, (5) Monzogranito Ilha Anchieta, (6) Gruta que Chora, (7) Brecha Magmática Ilha Anchieta, (8) Xenólitos do Manto e Cones de Explosão, (9) Pico do Corcovado e (10) Pedreira Itamambuca. Média de Vci = 2,78 e Vtur = 1,62.

Em análise aos resultados parciais referentes ao tipo de interesse dos geossítios, no método GEOSSIT são calculados Interesse Científico (Ic), Interesse Didático (Id) e Interesse Turístico (It). Os resultados obtidos são expressos no gráfico 7.4.4.7a e mostram que, exceto o geossítio Pedreira Itamambuca, os demais têm valores de Ic, maior que Id e It, conforme esperado, pois este geossítio foi incluído neste inventário especialmente pelo seu interesse histórico-cultural e uso potencial turístico e didático.

Em relação à $I d$, alguns geossítios atingiram a mesma pontuação e aparecem juntos em primeiro lugar, são eles: Gruta que Chora, Xenólitos do Manto e Cones de Explosão e Pedreira Itamambuca. Seguem-se os geossítios Praia do Cedro do Sul, Pedra do Sino de Ubatuba e Monzogranito Ilha Anchieta, que aparecem em segundo lugar. Em terceiro e quarto lugares estão a Brecha Magmática Ilha Anchieta e Charnockito Ubatuba. Finalmente em quinto lugar, a Praia da Ponta Aguda e em sexto o Pico do Corcovado (Gráfico 7.4.4.7b). Os geossítios que ocupam as últimas posições podem ter sido "prejudicados" principalmente pelas notas atribuídas aos parâmetros analisados para o cálculo desde índice. Por exemplo, ambos não são reconhecidos como local-tipo, não apresentam elementos de interesses históricos e 
culturais, têm dificuldade de acesso (somente por trilhas) e não têm a imagem fortemente vinculada à divulgação turística.

No que diz respeito a It os geossítios foram seriados na seguinte ordem: Gruta que Chora, Pedreira Itamambuca, Monzogranito Ilha Anchieta, Xenólitos do Manto e Cones de Explosão, Pico do Corcovado, Brecha Magmática e Pedra do Sino de Ubatuba (empatados em quinto lugar), Charnockito Ubatuba, Praia do Cedro do Sul e Praia da Ponta Aguda (empatados em sétimo lugar) (Gráfico 7.4.4.7c). O geossítio Xenólitos do Manto e Cones de Explosão aparece em uma colocação inesperada (em quarto lugar) comparada aos demais geossítios. Esta colocação pode ter sido potencializada principalmente pelas notas atribuídas aos parâmetros B4 (acessibilidade) B5 (proximidade de povoação) e B6 (população a ser beneficiada com a utilização/ divulgação do geossítio) que para It tem pesos maiores, que em Ic e Id.

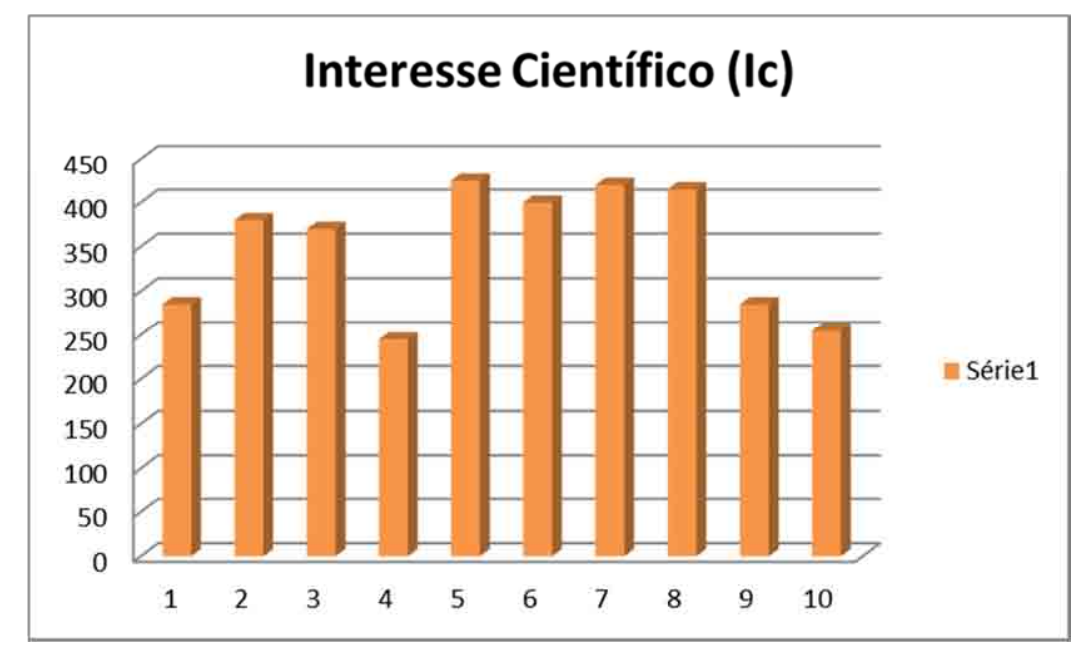

Gráfico 7.4.4.7 - Resultados obtidos pelo método GEOSSIT para os tipos de interesse dos geossítios. a - Interesse Científico (Ic). Geossítios: (1) Charnockito Ubatuba, (2) Praia do Cedro do Sul, (3) Pedra do Sino de Ubatuba, (4) Praia Ponta Aguda, (5) Monzogranito Ilha Anchieta, (6) Gruta que Chora, (7) Brecha Magmática Ilha Anchieta, (8) Xenólitos do Manto e Cones de Explosão, (9) Pico do Corcovado e (10) Pedreira Itamambuca. 

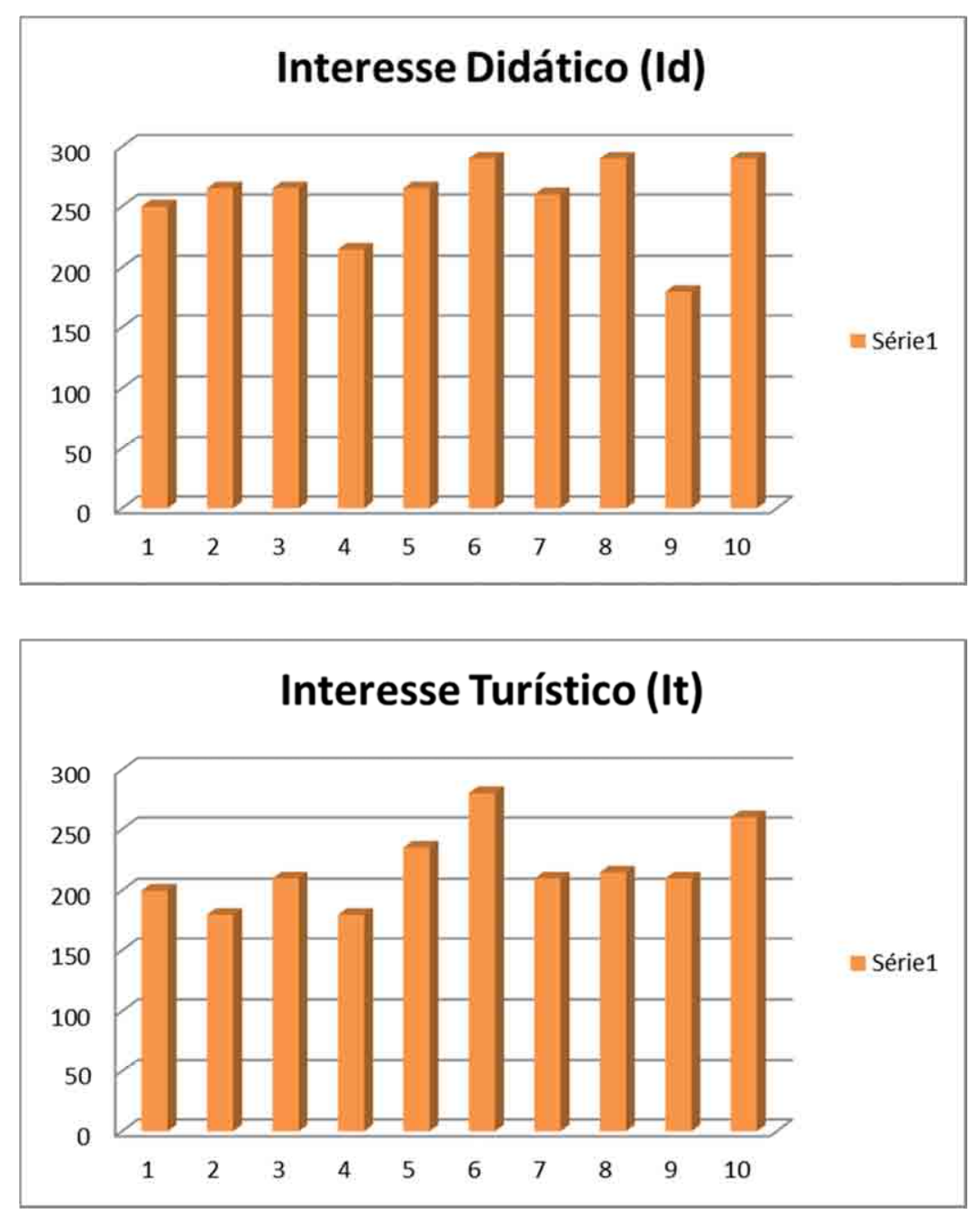

Gráfico 7.4.4.7 - Resultados obtidos pelo método GEOSSIT para os tipos de interesse dos geossítios. b - Interesse Didático (Id); c - Interesse Turístico (It). Geossítios: (1) Charnockito Ubatuba, (2) Praia do Cedro do Sul, (3) Pedra do Sino de Ubatuba, (4) Praia Ponta Aguda, (5) Monzogranito Ilha Anchieta, (6) Gruta que Chora, (7) Brecha Magmática Ilha Anchieta, (8) Xenólitos do Manto e Cones de Explosão, (9) Pico do Corcovado e (10) Pedreira Itamambuca.

Finalmente, no método de Pereira - de modo semelhante aos tipos de interesse calculados no GEOSSIT - é calculado o valor de uso científico (VUC), turístico (VUT) e valor de conservação (VC) dos geossítios a partir dos resultados parciais das categorias Vci, Vi, Vtur e Vug. O gráfico 7.4.4.8a mostra os resultados referentes ao Valor de Uso Científico que expressa a relevância científica dos geossítios inventariados em Ubatuba, seriando-os na seguinte ordem: Brecha Magmática Ilha Anchieta (primeiro lugar), Xenólitos do Manto e Cones de Explosão (segundo lugar), Monzogranito Ilha Anchieta, Gruta que Chora e Charnockito Ubatuba (empatados em terceiro lugar), Praia do Cedro do Sul e Praia da Ponta 
Aguda (empatados em quarto lugar), Pedra do Sino de Ubatuba (em quinto lugar) e Pico do Corcovado e Pedreira Itamambuca (em sexto lugar). Os geossítios que ocupam as três primeiras posições apresentam valores de VUC acima da média, calculada em 2,57.

Comparando-se os resultados de VUC aos resultados de Ic calculados na plataforma GEOSSIT, nota-se que os geossítios que aparecem nas primeiras posições são os mesmos nos dois métodos: Monzogranito llha Anchieta (primeiro lugar), Brecha Magmática Ilha Anchieta (segundo lugar), Xenólitos do Manto e Cones de Explosão (em terceiro) e Gruta que chora (em quarto lugar) no GEOSSIT. Esta proximidade na seriação dos geossítios nos dois métodos pode ser explicada pelo conjunto de valores analisados nas categorias Ic e VUC, que são muito parecidos, por exemplo, os parâmetros "abundância e raridade", "grau de conhecimento científico", "tipos de interesse" ou "variedade de elementos da geodiversidade" e "representatividade na ilustração de modelos, processos ou unidades geológicas".

Em relação a VUT, os resultados obtidos expressam o potencial de uso como atrativo turístico de cada geossítio. Mediante a esses resultados, os geossítios foram classificados na seguinte ordem: Monzogranito Ilha Anchieta, Pico do Corcovado, Gruta que Chora, Charnockito Ubatuba, Pedra do Sino de Ubatuba, Pedreira Itamambuca, Praia do Cedro do Sul, Brecha Magmática Ilha Anchieta e Xenólitos do Manto e Cones de Explosão (Gráfico 7.4.4.8b). Observa-se que as duas primeiras posições nesta categoria são ocupadas por geossítios inseridos nos parques estaduais, o Monzogranito Ilha Anchieta, no PEIA e o Pico do Corcovado no limite entre os núcleos Pincinguaba e Santa Virgínia do PESM. Ambos tiveram suas notas elevadas por serem contemplados em sua totalidade pelos parâmetros $\mathrm{C} 3$ (presença de infraestrutura), C4 (existência de utilização em curso) e C5 (presença de mecanismo de controle de visitantes), diferente, por exemplo, do geossítio Brecha Magmática Ilha Anchieta, que embora se localize no PEIA, obteve notas muito menores C3 e C4 e não foi comtemplado por nenhuma das alternativas oferecidas em C2.

O geossítio Xenólitos do Manto e Cones de Explosão, que no GEOSSIT em It ocupa a quarta posição, neste método em VUT aparece apenas na oitava. Mais uma 183 
vez a principal diferença entre as duas posições ocupadas em cada método, devese ao fato deste geossítio ter sido beneficiado pelo conjunto de parâmetros avaliados para o cálculo de It, em especial pelos parâmetros B5 e B6. Por outro lado, em VUT ao mesmo geossítio foram atribuídas as menores notas em C3 e C5, contribuindo para baixa colocação nesta categoria.

Por ultimo, o gráfico 7.4.4.8c apresenta os resultados valor de conservação (VC) que se refere à importância de conservação dos elementos da geodiversidade ilustrados nos geossítios. Deste modo, os geossítios são seriados na seguinte ordem: Gruta que Chora, Brecha Magmática Ilha Anchieta, Pedra do Sino de Ubatuba, Xenólitos do Manto e Cones de Explosão, Praia da Ponta Aguda, Praia do Cedro do Sul, Charnockito Ubatuba e Monzogranito Ilha Anchieta (em sétimo lugar), Pedreira Itamambuca e Pico do Corcovado.

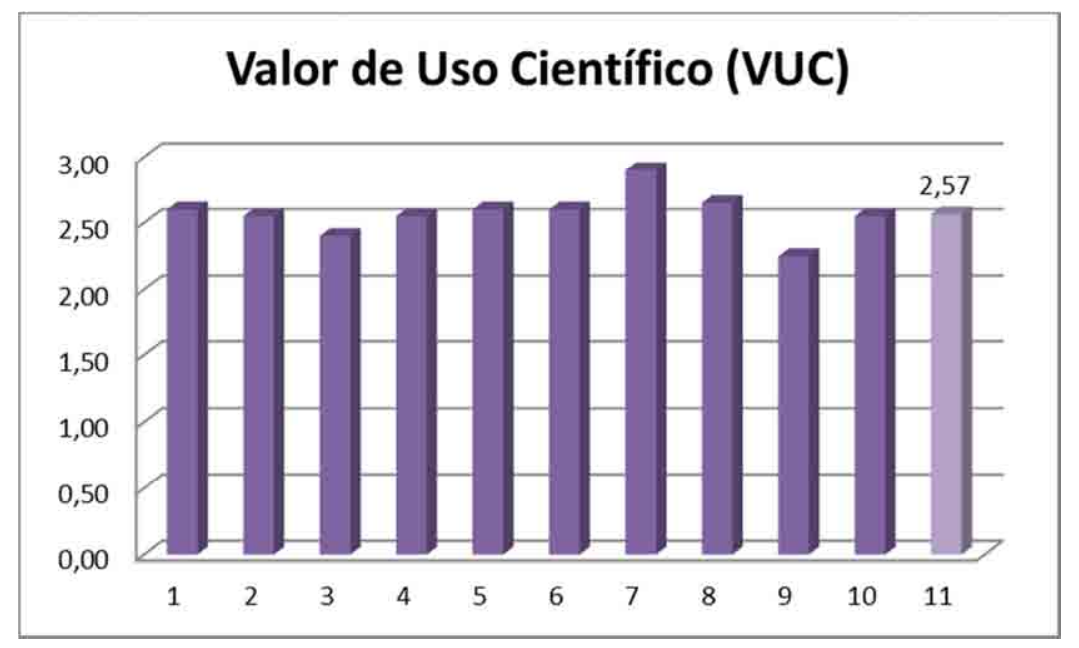

Gráfico 7.4.4.8a- Resultados obtidos pelo método de Pereira (2010) para o Valor de Uso Científico (VUC). Média de VUC = 2,57. 


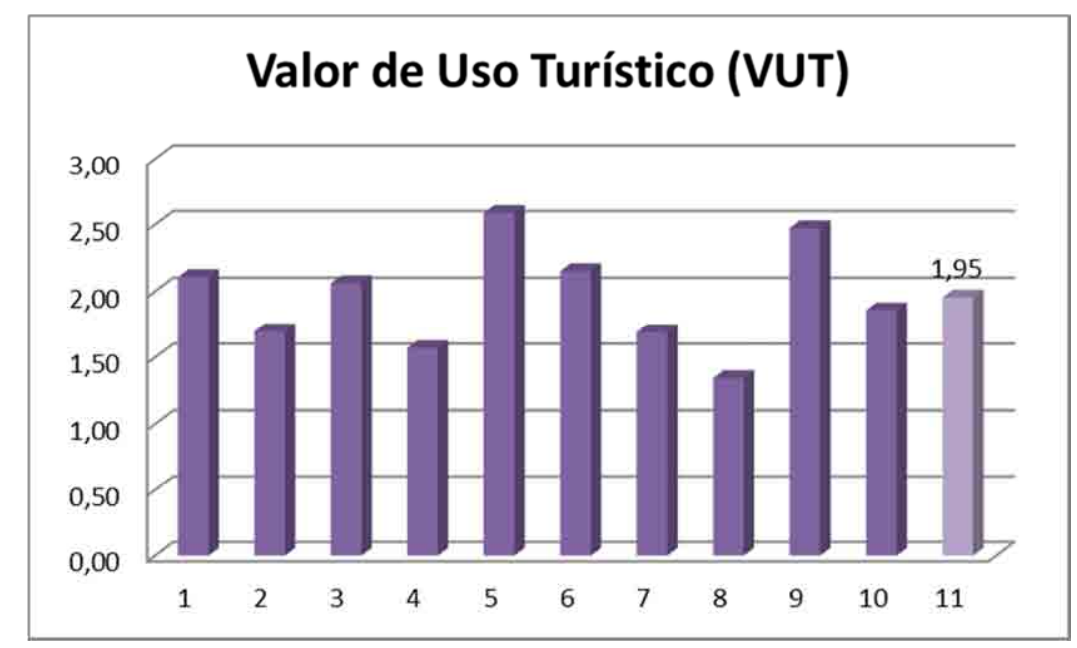

Gráfico 7.4.4.8b - Resultados obtidos pelo método de Pereira (2010) para o Valor de Uso Turístico (VUT). Média de VUT = 1,95.

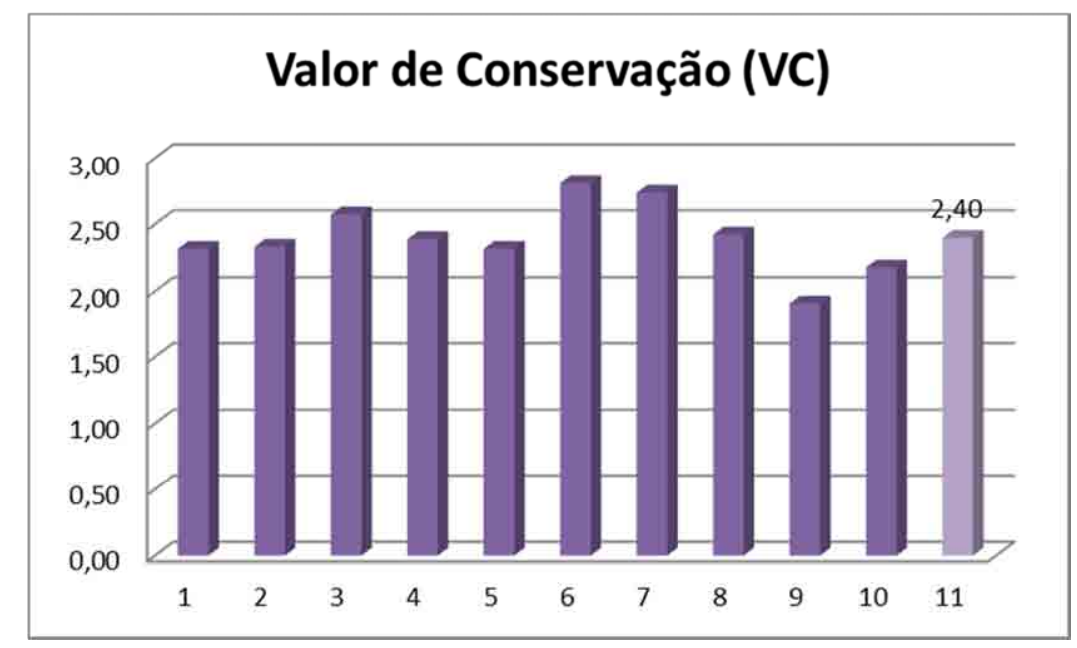

Gráfico 7.4.4.8c - Resultados obtidos pelo método de Pereira (2010) para o Valor de Conservação (VC). Média de VC = 2,40. Geossítios: (1) Charnockito Ubatuba, (2) Praia do Cedro do Sul, (3) Pedra do Sino de Ubatuba, (4) Praia Ponta Aguda, (5) Monzogranito Ilha Anchieta, (6) Gruta que Chora, (7) Brecha Magmática Ilha Anchieta, (8) Xenólitos do Manto e Cones de Explosão, (9) Pico do Corcovado, (10) Pedreira Itamambuca e (11).

\subsubsection{Conclusões sobre a quantificação}

Os resultados da quantificação de relevância dos geossítios permitiu a avaliação dos três métodos testados neste trabalho. Com relação ao método de Brilha (2005) os geossítios foram seriados com base no valor de (Q), que prioriza o valor científico dos geossítios. Comparado aos demais métodos testados, considerase que este é o mais simples e objetivo de ser aplicado, porém as alternativas 
sugeridas em alguns parâmetros não condizem com a realidade brasileira. Neste sentido, se fez necessária a adaptação desses parâmetros para contemplar a área enfocada (como apresentado em 7.4.1.).

A plataforma GEOSSIT é o método mais complexo de aplicação comparado aos demais testados neste trabalho. A quantificação baseia-se nas categorias $A, B$ e C do método de Brilha e apresenta um conjunto de parâmetros cujas alternativas foram adaptadas para o contexto nacional. Contudo, a inclusão da categoria Vulnerabilidade advinda da metodologia de García-Cortés \& Urquí (2009) adicinou três parâmetros já considerados anteriormente na categoria C (como abordado em 7.4.2). Assim os geossítios que obitveram tiveram notas altas em $V$, quando calculada a prioridade de proteção (baseada nos resultados de $\lg +V$ ), ocuparam posições mais altas no "ranking final", deixando os geossítios que apresentam maior interesse científico em posições mais baixas. Como exemplo temos o geossítio Pedreira Itamambuca, que alcançou primeiro lugar na prioridade de proteção por apresentar o maior valor $V$ entre todos os geossítios. Em contrapartida, os geossítios Monzogranito Ilha Anchieta e Brecha Magmática Ilha Anchieta, que alcançaram os maiores valores em lc, ocupam a sétima e oitvava posições no "ranking final".

A quantificação pelo método de Pereira (2010) apresentou resultados mais parecidos ao método de Brilha (2005). Ao final, os mesmos geossítios aparecem nas primeiras posições: Monzogranito Ilha Anchieta, Brecha Magmática Ilha Anchieta e Gruta que Chora. Portanto, conclui-se que neste método, que destaca o valor turístico dos geossítios inicialmente como uma categoria específica (Vtur) e posteriormente como valor de uso (VUT), a quantificação final baseia-se prioritariamente no valor científico, que aparece com peso maior no cálculo final do Ranking de Relevância $(R)$. Além disso, este método é o que melhor se adequa a área de estudo, justamente por reunir parâmetros e alternativas que se aplicam ao contexto das unidades de conservação.

Deste modo, conclui-se que os métodos de quantificação de relevância dos geossítios, sobretudo os métodos mais recentes, necessitam ser testados, avaliados e discutidos por diferentes estudos de casos até que se encontrem parâmetros e alternativas que melhor representem os diferentes contextos do território brasileiro. 
Neste sentido, espera-se que o presente estudo possa contribuir no avanço dessas discussões e no refinamento dos métodos aqui testados.

\subsection{As Unidades de Conservação e a gestão do Patrimônio Geológico de Ubatuba}

Dando seguimento às etapas das estratégias de geoconservação, seguida às etapas de quantificação e classificação dos geossítios procede-se a etapa de gestão do patrimônio geológico. Esta etapa integra as ações de conservação, valorização e divulgação e monitoramento dos geossítios. Como abordado anteriormente (Capítulo 2), a conservação dos geossítios requer o desenvolvimento de intervenções para salvaguardar as propriedades físicas do geossítio e, ao mesmo tempo, garantir que o mesmo seja acessível ao público de acordo com o seu interesse turístico, pedagógico, científico, ou outros (BRILHA, 2005).

A valorização e a divulgação devem limitar-se aos geossítios que apresentarem baixa vulnerabilidade e melhores condições de uso. Estes podem ser integrados a diferentes meios interpretativos, roteiros geoturísticos, trilhas interpretativas, e divulgação geocientífica. Ainda, podem ser valorizados por meio de folhetos, painéis interpretativos, websites, dentre outros meios de comunicação.

Cabe ressaltar que, embora estas etapas tenham sido sistematizadas por Brilha (2005) como etapas sequenciais, constatou-se durante o desenvolvimento desta pesquisa que, em alguns casos as ações para a valorização e a divulgação dos geossítios inventariados poderiam desenvolvidas antes mesmo do processo de quantificação, como no caso dos geossítios inseridos nos parques estaduais (PEIA e PESM), os quais já recebem visitantes, porém, com o intuito de disfrutar da paisagem e conhecer prioritariamente a fauna e flora local. Para tanto, é necessário que estes locais apresentem baixa vulnerabilidade e boas condições de uso. Além disso, sugere-se que nestes casos os geossítios já tenha um "órgão" responsável pela sua gestão, para que os elementos da geodiversidade local não sejam comprometidos de maneira negativa.

Para Carcavilla-Urquí, Martinez \& Valsero (2007), como aponta Prochoroff (2014 p.124), "a divulgação e interpretação do patrimônio geológico prioritariamente 
em áreas protegidas (mas não restrita a elas), para evitar a depredação e aproveitar a conexão deste com a biodiversidade circundante, por exemplo".

Nesse contexto, foram elaboradas algumas propostas para gestão (conservação, valorização e divulgação) do Patrimônio Geológico de Ubatuba que podem contribuir para o desenvolvimento do turismo local, por meio do geoturismo.

\subsubsection{Ações pontuais para os geossítios de Ubatuba}

A seguir são apresentadas algumas propostas pontuais para a conservação valorização e divulgação do patrimônio geológico de Ubatuba. Para tanto, foram considerados o potencial turístico de cada geossítio baseando-se não somente nos resultados da quantificação, mas também na realidade observada localmente durante a realização das etapas de campo.

Dentre os geossítios inventariados em Ubatuba, três estão situados em parques estaduais: Monzogranito Ilha Anchieta e Brecha Magmática Ilha Anchieta, no Parque Estadual da Ilha Anchieta e o Pico do Corcovado, no limite entre os núcleos Picinguaba e Santa Virgínia do PESM. Os demais geossítios estão inseridos na APA marinha do litoral norte. Assim, sugere-se que as propostas apresentadas neste trabalho, para o desenvolvimento de ações para a promoção e gestão do patrimônio geológico local sejam desenvolvidas futuramente junto a estas UC.

O geossítio Monzogranito Ilha Anchieta está localizado na trilha do Saco Grande no Parque Estadual da Ilha Anchieta. À distância da trilha é de 2.600 metros (ida e volta) e seu grau de dificuldade é considerado médio. A trilha tem início na Praia do Presídio, passando pelas Ruínas do Quartel e da Vila Militar, palcos da rebelião dos presos em 1952. Na mata é possível observar de pequenos mamíferos da fauna introduzida e espécies de pássaros silvestres. Termina no costão rochoso com vista para o mar aberto (Figura 7.5.1.6a/b/c/d) (GARCIA \& SANTOS, $2012^{24}$ ). Durante o percurso desta trilha até a chegada ao geossítio não se encontram muitas informações, além da sinalização inicial e as marcações de percurso. Além disso, as

24 GARCIA, M.G.M; SANTOS, P.L.A. Potencial Geoturístico das Trilhas no Parque Estadual da Ilha Anchieta, Litoral Norte de São Paulo: Geoconservação e Divulgação Científica. Relatório de Iniciação Científica, aceito pela Pró-Reitoria de Graduação da Universidade de São Paulo, 2012. 
informações abordadas pelos monitores ambientais são apenas sobre os aspectos histórico-culturais da ilha.

Entretanto, o PEIA utiliza de diferentes meios comunicativos para divulgação dos locais turísticos: possui um centro de visitante onde se encontra uma pequena exposição sobre o período em que ilha passou de presídio militar a área de preservação, folhetos para divulgação das trilhas interpretativas e diferentes painéis contendo aspectos relevantes sobre a biodiversidade (Figura 7.5.1.7a/b). Assim, pensando na valorização e divulgação destes geossítios, sugere-se que o geossítio Monzogranito llha Anchieta seja integrado no conteúdo divulgativo do PEIA como os demais pontos turísticos. Como exemplo de informações que se pode divulgar a respeito do local dentre muitas ideias destaca-se: "a idade das rochas", que pode ser abordada por meio de painéis interpretativos ao longo do percurso da trilha abordando principalmente a fase se aglutinação do Supercontinente Gondwana.
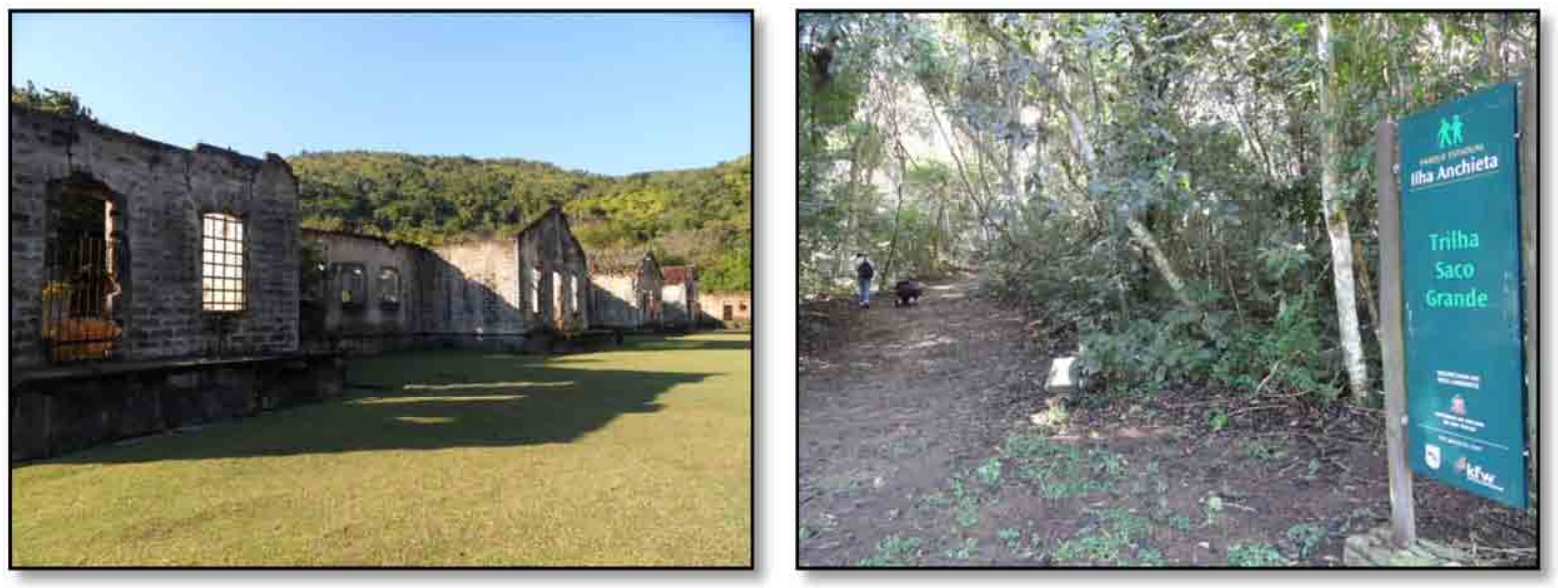

Figura 7.5.1.6 - a) Vista para o pátio e ruínas do antigo presídio militar, b) Início da Trilha do Saco Grande. 

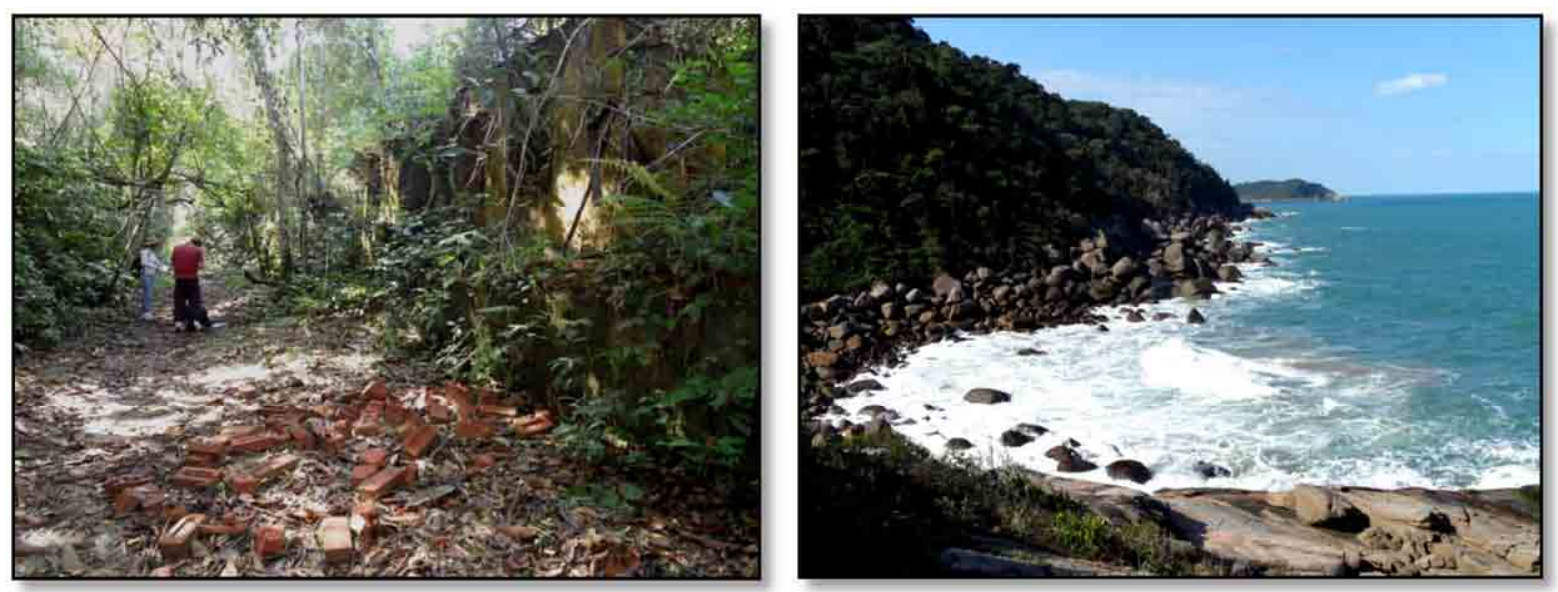

Figura 7.5.1.6 - c) Durante o percurso da trilha são encontradas ruínas da antiga vila militar da Ilha Anchieta, d) Vista para o mar a partir do geossítio Monzogranito Ilha Anchieta.

O geossítio Brecha Magmática Ilha Anchieta, também localizado no parque, embora não tenha grande potencial de visitação por questões de acesso, que é feito somente de barco e de segurança, de certa forma também pode ser divulgado no PEIA tanto nos folhetos quanto no centro de visitantes. Contudo, o conteúdo divulgativo, destinar-se-ia ao público adulto apenas para conhecimento do local.

Vale salientar a que a gestão destes geossítios junto ao PEIA tem grande viabilidade, uma vez que esta UC já dispõe de diversos meios interpretativos (como painéis, centro de visitantes, folhetos e websites) e a prática do turismo é muito bem planejada, com controle de visitantes, acompanhamento por guias e sinalização adequada nas trilhas ecoturísticas. Além disso, a "discussão prévia" sobre integração entre os aspectos da biodiversidade e geodiversidade na prática do turismo local, de certo modo já foram introduzidos, durante a realização do projeto "Trilhas subaquática Educação Ambiental nos ecossistemas marinhos", realizado em parceria com o Instituto de Biociências da Universidade de São Paulo e a ONG Ecosteiros durante os meses de Janeiro e Fevereiro. Atualmente, além do conhecimento sobre a fauna e flora marinha, há a intenção de introduzir novas abordagens sobre os aspectos da geodiversidade, como a origem e formação do solo e dos sedimentos encontrados na praia e os processos de formação da linha de costa da região litorânea. 

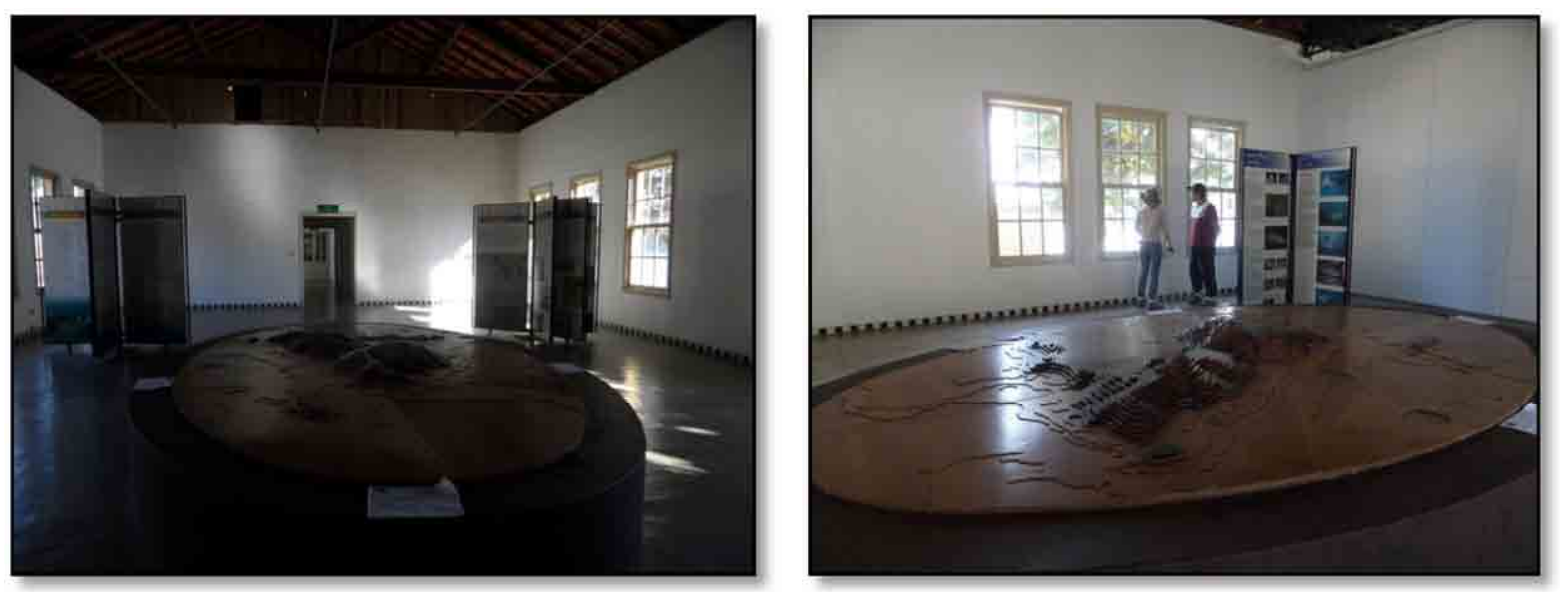

Figura 7.5.1.7 - a) e b) Centro de visitantes do PEIA, onde são expostos diversos painéis que relatam a história da llha enquanto presídio militar e uma maquete da ilha com detalhes topográficos.

O geossítio Pico do Corcovado encontra-se inserido no limite entre os núcleos Picinguaba e Santa Virgínia do PESM. Este geossítio pode ser visitado pelo percurso de trilhas monitoradas a partir de ambos os núcleos. Sendo assim, sugerem-se as intervenções para divulgação deste local seja realizada junto aos centros de interpretação ambiental dos dois núcleos. As propostas para divulgação do local referem-se à formação das feições geomorfológicas observadas a partir do geossítios: a planície costeira e a Serra do Mar. Propõe-se que estas informações possam ser integradas à "fala" dos condutores a partir de cursos de formação e palestras oferecidas nas UC. Esta prática já vem sendo realizada pelo GeoHereditas nas UC com o oferecimento do curso de Introdução às Geociências, contudo, ao retornar nos núcleos passado determinado tempo, nota-se que é necessário que estes cursos sejam oferecidos periodicamente como forma de resgatar conceitos já abordados e introduzir novos conceitos de geologia para estes guias (Figura 7.5.1.8a/b). 

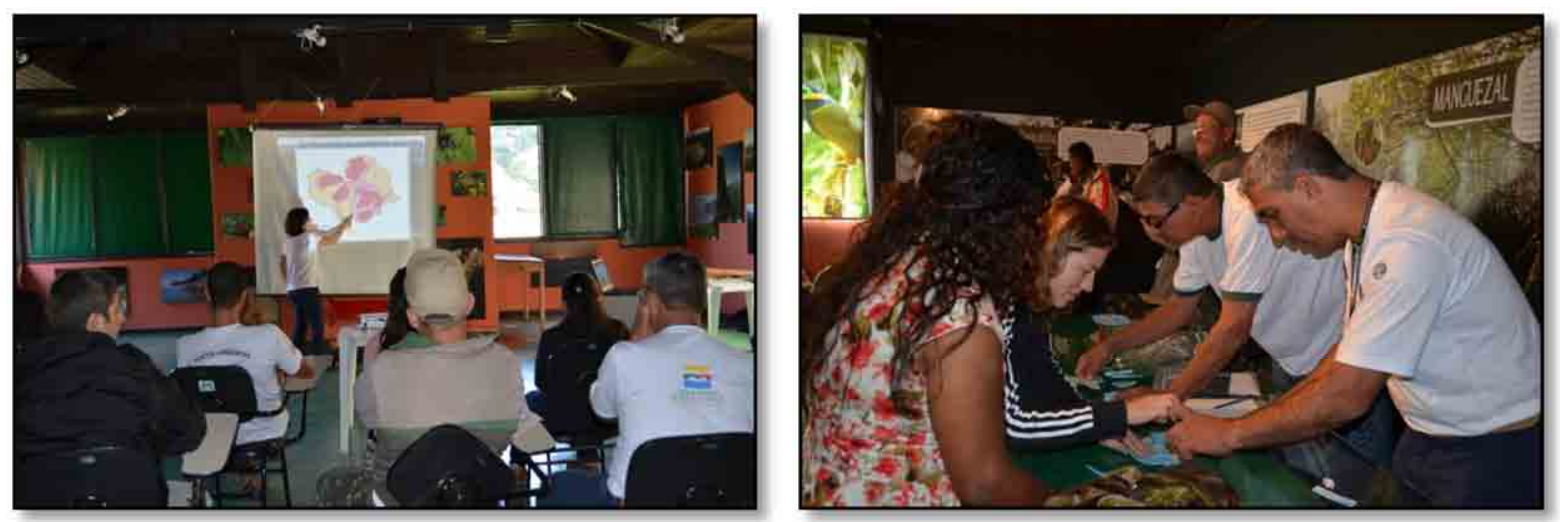

Figura 7.5.1.8 - a) e b) Atividades realizadas durante o curso de Introdução às Geociências oferecido no Núcleo Picinguaba do PESM em 2012.

Extrapolando a ideia inicial de gestão aqui apresentada, para estes geossítios descritos acima, pode-se ainda proceder à etapa de monitoramento integrada as ações de gestão e manejo as atividades turísticas. Atualmente, os Núcleos Santa Virgínia e Picinguaba do PESM realizam manutenção de acesso das trilhas e avaliação de riscos de ameaças antrópicas ou naturais. Já o PEIA dispõe de controle de visitantes por meio de registros de visitação e manutenção das trilhas que ocorrem anualmente.

Em relação aos geossítios Gruta que Chora, Charnockito Ubatuba, Pedra do Sino de Ubatuba e Pedreira Itamambuca, segundo os resultados obtidos pelos métodos GEOSSIT e de Pereira (2010), apresentam grande potencial de interesse e uso turístico. A estes geossítios, somados à Praia do Cedro do Sul, já havia sido atribuído este tipo interesse a partir das observações de campo. A valorização e divulgação destes geossítios, em geral, podem ser feitas também pela inclusão destes locais em roteiros geoturísticos e folhetos divulgativo e, eventualmente, pela elaboração de painéis interpretativos.

O geossítio Gruta que Chora está localizado na Praia da Sununga e, inicialmente, não se considera a proposição de nenhum painel para o local justamente porque a inclusão causaria um impacto visual muito grande de maneira negativa. Além disso, a gruta encontra-se em processo de formação, podendo haver queda de blocos em períodos muito curtos danificando muito rapidamente qualquer estrutura próxima a ela. Também, deve-se considerar que o local tem variações de 
maré muito intensas, que também contribuiriam para rápida degradação de possíveis estruturas. Portanto, uma alternativa para a divulgação do local seria a elaboração de materiais impressos (folhetos) que poderiam ser distribuídos pelos quiosques na própria praia, hotéis e campings ao redor. Em relação ao conteúdo deste material, sugere-se abordar além do processo de formação - o principal caráter geocientífico, as diversas lendas que rodeiam a gruta, como forma de incentivar o conhecimento histórico e a cultura local.

Os geossítios Charnockito Ubatuba ${ }^{25}$, na Praia do Prumirim, Pedra do Sino de Ubatuba, na Praia da Santa Rita e Pedreira Itamambuca, na Praia de Itamambuca, localizam-se em locais os quais são bastante visitados, principalmente na alta temporada. A presença de infraestrutura e comerciantes (quiosques, restaurantes e hotéis) nestas praias favorece a divulgação destes geossítios. Deste modo, sugerese o estabelecimento de uma parceria entre própria associação Casa do Artesão e comércio na venda de produtos que remetem à divulgação dos geossítios e à importância de conservar estes locais. Além disso, estes locais favorecem a instalação de painéis contendo informações, por exemplo, sobre a importância geológica das rochas charnockíticas e retomando o contexto histórico de extração destas rochas. Em especial para a Pedra do Sino de Ubatuba, pode-se elaborar uma proposta de painel que "converse" com sugestão apresentada por Prochoroff (2014) para o geossítio "Pedra do Sino" situado na Ilhabela, em que são abordadas questões como "geologia, física, música na praia".

O geossítio Praia Ponta Aguda não apresentou grande potencial para a realização de atividades turísticas. Porém, pode-se ser divulgado para comunidade cientifica e usado para a realização de atividades direcionadas a estudantes de Geologia como belíssimos exemplos de registros magmáticos e metamórficos que ocorreram durante o Neoproterozoico.

\footnotetext{
${ }^{25}$ Um painel interpretativo para o geossítio Charnockito Ubatuba encontra-se em fase de elaboração por um projeto em desenvolvimento do GeoHereditas com apoio da Fapesp. Este projeto prevê a instalação de 10 painéis no litoral norte do estado de São Paulo incluindo os municípios de Caraguatatuba, São Sebastião, Illhabela e Ubatuba.
} 
Em especial, o geossítio Xenólitos do Manto e Cones de Explosão ${ }^{26}$ situado na Praia Vermelha do Centro, em discussões preliminares a respeito da valorização e divulgação sugere-se que pela sua importância e raridade, esse geossítio poderia ser divulgado inicialmente para a comunidade cientifica. Como está localizado em uma praia bastante visitada em Ubatuba, pode ser divulgado para os turistas em roteiros geoturísticos, mas não seria alvo para o público escolar (como ensino fundamental) principalmente por não ser de fácil acesso por questões de segurança.

Ao considerar-se a possibilidade de todos os geossítios serem divulgados por meio de roteiros geoturísticos, a exemplo dessa iniciativa temos os roteiros elaborados para a realização da atividade prática durante o curso de Introdução às Geociências (anexos 1, 2 e 3). Estes roteiros são compostos por pontos de interpretação geológica ao longo das trilhas ecoturísticas das UC, em alguns casos, os geossítios localizados no percurso da trilha integram o roteiro e aparecem com destaque especial, por exemplo, o roteiro (geo) interpretativo da Praia Brava, no município de São Sebastião em que ao longo do percurso encontra-se o geossítio "Mirante da Praia Brava" descrito por Reverte (2014).

Finalmente, deve-se ainda considerar a divulgação do patrimônio geológico de Ubatuba via internet. Inicialmente pode-se investir na integração de informações sobre a história geológica regional e local, somadas a informações específicas sobre os geossítios nos próprios sites das UC, como é feito com as trilhas, em que há informações disponibilizadas aos visitantes sobre percurso, pontos turísticos e curiosidades. Em médio prazo, investir na criação de um site próprio para a veiculação de informações sobre o patrimônio geológico e geoconservação integrando-as aos demais municípios do litoral norte do estado de São Paulo ${ }^{27}$.

\footnotetext{
${ }^{26}$ As discussões a respeito da valorização e divulgação deste geossítio foram realizadas com os professores José Bernardo R. Brilha e Maria da Glória Motta Garcia, durante a atividade de campo realizada em agosto de 2013 junto à disciplina de Pós-graduação "Patrimônio Geológico e Geoconservação" oferecida pelo Programa de Pós-graduação em Mineralogia e Petrologia do Instituto de Geociências da USP.

27 Atualmente o GeoHereditas está desenvolvendo um site para divulgação dos geossítios inventariados no litoral norte do estado de São Paulo. As informações compiladas referem-se às características geológicas, localização e descrições referentes às principais aspectos locais.
} 


\subsection{Conclusões e perspectiva para estudos futuros}

O estudo da geodiversidade de Ubatuba permitiu a realização do inventário do patrimônio geológico local, que é composto preliminarmente por dez geossítios. Estes geossítios foram escolhidos levando-se em consideração principalmente o valor cientifico, ou seja, os registros de importantes eventos associados à evolução geológica do sudeste brasileiro. Ademais, foram considerados valores turísticos e histórico-cultural da área enfocada.

A realização deste inventário permitiu o teste de diferentes métodos de quantificação de relevância dos geossítios. A partir dos resultados obtidos percebese que, embora nas últimas décadas os estudos sobre a temática tenham avançado muito no Brasil, existe uma necessidade muito grande em testar e avaliar os diferentes métodos propostos até que se estabeleçam parâmetros que contemplem os diferentes contextos da nossa realidade territorial.

Contudo, esta etapa não pode ser vista como única e determinante para que os geossítios sejam submetidos às etapas de gestão (conservação, valorização e divulgação), pois determinado local pode apresentar "atributos" que reflitam diretamente no ranking de relevância, e o mesmo ser beneficiando quando em realidade pode apresentar menor potencial (científico, didático e turístico) que outros locais. Portanto, como aqui já explicitado, espera-se que as discussões apresentadas futuramente possam contribuir no avanço e refinamentos dos métodos testados.

Acredita-se que a realização deste inventário, bem como as propostas apresentadas para a valorização e divulgação do patrimônio geológico, possam contribuir para a divulgação das geociências e da importância da conservação do meio natural como um todo - integrando a biodiversidade e geodiversidade. Para tanto, acredita-se que a maneira mais efetiva seja por meio da inserção do conceito de geoturismo - entendido como uma prática educativa e indutor econômico - junto às Unidades de Conservação e aos demais setores envolvidos nas atividades turísticas locais. A sua implementação nas UC por meio da interpretação ambiental, como sugere Bento (2013), pode contribuir também para que as questões sobre a geodiversidade e a geoconservação sejam valorizadas e inseridas no plano de manejo pelos gestores dos parques. Ademais, espera-se que os pontos identificados 195 
possam contribuir tanto para a administração pública dos municípios como base para a elaboração de documentos e relatórios em futuros planos de gestão territorial, quanto para a investigação científica e mapeamento geológico do litoral do estado de São Paulo.

Finalmente, cabe ressaltar que o inventário aqui apresentado e os resultados obtidos não são imutáveis ou acabados. Estes integram um projeto maior que prevê a realização do inventário do patrimônio geológico de todo o litoral do estado de São Paulo, integrando os diferentes municípios, vários dos quais já se encontram em fase de desenvolvimento e conclusão. 


\section{REFERÊNCIAS BIBLIOGRÁFICAS}

AÇORES - Geoparque Açores. Disponível em: http://www.azoresgeopark.com/. Acesso em 15 Fev. 2014.

ALENCOÃO, A., SERÔDIO, A., FARIA, A., GOMES, E., MOREIRA, H., SANTOS, J. A., et al. (2010). Pedestrianismo, uma abordagem multidisciplinar: ambiente, aptidão física e saúde. Universidade de Trás-os-Montes e Alto Douro. Vila Real, PT. 125 p. 2010.

ALMEIDA F.F.M. Origem e evolução da plataforma brasileira. Rio de Janeiro, DNPMDGM, Boletim, v.241, p. 5-36, 1967.

ALMEIDA, F.F.M. Diferenciação tectônica da plataforma brasileira. In: Anais do Congresso Brasileiro de Geologia. Salvador, v.23, p. 29-46, 1969.

ALMEIDA, F.F.M.; AMARAL, G.; CORDANI, U.G.; KAWASHITA, K., The Precambrian evolution of the South American Catronic Margin South of Amazon River. In: NAIRN \& STELLI, (Eds.) The Ocean Basin and Margins, Nova York: Plenum, v.1, p.411-446, 1973.

ALMEIDA, F.F.M.; HASUI, Y.; BRITO NEVES, B.B.; FUCK, R.A.1981. A brazilian structural provinces: an introduction. Earth-Science Reviews, 17(1/2): 1-29.

ALMEIDA, F.F.M. Províncias estruturais brasileiras. In: Atas do VIII Simpósio de Geologia do Nordeste. Campina Grande, v.8, p. 363 - 391, 1977.

ALMEIDA, F.F.M. \& CARNEIRO C.D.R. Origem e evolução da Serra do Mar. 2008. Revista de Geociências, 28 (2) $135-150$ p.

ALMEIDA, V.V. Mineralogia e petrologia de xenólitos mantélicos das regiões de Ubatuba (SP) e Monte Carmelo (MG): evidências de fusão parcial e metassomatismo no manto superior do sudeste do Brasil. 2009. 112p. e anexos Dissertação de Mestrado, instituto de Geociências, Universidade de São Paulo. 2009.

ANDRADE, C. E. de; CUNHA, C.M.L. Análise do relevo paulista (Brasil) através da cartografia geomorfológica. In: Anais do VI Seminário Latino Americano de Geografia Física, II Seminário Ibero Americano de Geografia Física, Universidade de Coimbra, 2010.

ARARIPE - Geopark Araripe. Disponível em: http://geoparkararipe.blogspot.com.brl. Acesso em 15 Fev. 2014.

AROUCA (Arouca Geopark, Portugal), Declaração de Arouca, Congresso Internacional de Geoturismo - Geotourism in Action - Arouca, 2011. Disponível em: http://www.geoparquearouca.com/geotourism2011/adm/upload/30.declaracao de arou ca pt.pdf. Acesso em Nov. 2012. 
AROUCA - Arouca Geopark. Disponível em: http://www.geoparquearouca.com/. Acesso em 05 Fev. 2014.

AZEVEDO SOBRINHO, J.M., JANASI, V.A., SIMONETTI, A., HEAMAN, L.M., SANTORO, J., DINIZ, H.N., 2011. The llha Anchieta Quartz Monzonite: the southernmost expression of $\mathrm{Ca}$. 500 Ma post-collisional magmatism in the Ribeira Belt. Anais da Academia Brasileira de Ciências 83(3): 891-906.

AZZONE, R. G.; RUBETI, E.; ENRICH G. E. R.; GOMES, C. B. Geologia e geocronologia do Maciço Alcalino Máfico-Ultramáfico Ponte Nova (SP-MG) Geologia USP: Série Científica, v. 9, n. 2, p. 23-46, 2009.

BARRETO, J.M.C. Potencial Geoturístico da Região de Contas - Bahia - Brasil. 2007. Dissertação de Mestrado em Geologia, Universidade Federal da Bahia - UFBA. Salvador, BA, 139 p. 2007.

BENTO, L.C.M.; RODRIGUES, S.C. Geoturismo em Unidades de Conservação: uma nova tendência ou uma necessidade real? - estado da arte. 2013. Revista do Departamento de Geografia - USP, Vol. 25, 77-97 p. 2013.

BIZZI, L. A.; GONÇALVES J.H.; SCHOBBENHAUS C.; VIDOTTI, R. M. (eds.). Geologia, tectônica e recursos minerais do Brasil: texto, mapas \& SIG. Brasília: CPRM Serviço Geológico do Brasil, 2003. 692 p.

BRANCO, P.M. Dicionário de mineralogia e gemologia. 2008. São Paulo: Oficina de Textos, 2008. 608p. il.

BRASIL - Decreto-Lei $n^{\circ} 289$, de 28 de fevereiro de 1967. Cria o Instituto Brasileiro do Desenvolvimento Florestal e dá outras providências.

BRASIL - Decreto No 73.791, DE 11 de Março de 1974. Cria a Reserva Biológica Nacional de Poço das Antas, no Estado do Rio de Janeiro, com os limites que especifica e dá outras providências.

BRASIL - Lei No 6.902 de 27 de abril de 1981. Dispõe sobre a criação de Estações Ecológicas, Áreas de Proteção Ambiental e dá outras providências.

BRASIL - Lei № 9.985 de 18 de julho de 2000. Regulamenta o art. 225, § $1^{\circ}$, incisos I, II, III e VII da Constituição Federal, institui o Sistema Nacional de Unidades de Conservação da Natureza e dá outras providências.

BRASIL - Decreto-lei 25/37. Organiza a proteção do patrimônio histórico e artístico nacional. 
BRASIL - Lei 6513/77 | Lei no 6.513, de 20 de dezembro de 1977. Dispõe sobre a criação de Áreas Especiais e de Locais de Interesse Turístico; sobre o Inventário com finalidades turísticas dos bens de valor cultural e natural.

BRASIL - Lei No 9.629, de 29 de Março de 1977. Cria o Parque da Estadual da Ilha Anchieta e dá providencias correlatas.

BRASIL - Decreto $N^{\circ} 10.251$ de 30 de Agosto de 1977. Cria o Parque Estadual da Serra do Mar e dá providências correlatas.

BRASIL - Decreto de Lei 53.525 de 08 de Outubro de 2008. Cria a Área de Proteção Ambiental Marinha do Litoral Norte e a Área de Relevante Interesse Ecológico de São Sebastião, e dá providências correlatas.

BRILHA, J. Patrimônio Geológico e Geoconservação: a conservação da natureza na sua vertente geológica. Viseu: Palimage Editores, 2005. 190 p.

BRITO-NEVES, B.B., CAMPOS-NETO, M.D., FUCK, R.A., 1999. From Rodinia to Western Gondwana: An approach to the Brasiliano-Pan-African Cycle and orogenic collage. Episodes 22(3), 155-166.

CAMPANHA, G.A.C., Ens, H.H., 1996. Estruturação geológica da Serra de Juqueriquerê, São Sebastião, SP. Boletim Instituto de Geociências USP 27:1-15.

CARCAVILLA URQUÍ, L.; MARTÍNEZ, J.L.; VALSERO, J.J.D. Patrimonio geológico y geodiversidad: investigación, conservación, gestión y relación con los espacios naturales protegidos. Instituto Geológico y Minero de España. Cuadernos del Museo Geominero, v. 7, 2007.

CARCAVILLA, L., DURÁN, J.J., LÓPEZ - MARTÍNEZ, J. Geodiversidad: concepto y relación con el patrimonio geológico. Geo-temas, 10, 1299-1303. VII Congreso Geológico de España. Las Palmas Gran Canaria. 2008.

COUTINHO, J.M.V.; ENS, H.H. Diques lamprofíricos e diferenciados carbonatíticos da região de São Sebastião e Itanhaém - SP (resultados preliminares). In: CONGRESSO BRASILEIRO DE GEOLOGIA, 37, 1992, São Paulo. Boletim de Resumos Expandidos. São Paulo: SBG/NSP, 1992. p. 512-513.

COUTINHO, J.M.V. Dyke swarms of the Paraná Triple Junction, southern Brazil. Revista do Instituto de Geociências- USP Serie Científica, São Paulo, v. 8, n. 2, p. 29-52, 2008.

CPRM. Mapa Geológico do estado de São Paulo. Escala 1: 750.000. Legenda expandida. Brasília: CPRM/Serviço Geológico do Brasil, 2006. CD-ROM. Disponível em: http://geobank.sa.cprm.gov.brl. Acesso em Maio. 2014. 
DIAS NETO, C.M., CORREA, C.T., TASSINARI, C. C. G., MUNHÁ, J.M.U., 2009. Os anfibolitos do Complexo Costeiro na Região de São Sebastião-SP. Revista do Instituto de Geociências USP 9(3): 71-87.

DRM-RJ - Serviço Geológico do estado do Rio de Janeiro. Disponível em: http://www.drm.rj.gov.br/. Acesso em 25 Fev. 2014.

DROGUETT, J.; FONSECA, J.O. Ubatuba: espaço memória e cultura. Editora Arte e Ciência. São Paulo, 2005. 303p.

DRUMMOND, J.A., FRANCO, J.L.A., OLIVEIRA, D. Uma análise sobre a história e a situação das unidades de conservação no Brasil. Conservação da Biodiversidade Legislação e Políticas Públicas. 341 - 385 p. 2010.

EBERT, H.D. 1968. Ocorrência de fácies granulítica no sul de Minas Gerais e em áreas adjacentes em dependência da estrutura orogênica: hipótese sobre a sua origem. Anais da Academia Brasileira de Ciências, 40: 215-229 (suplemento). 1968.

FF - Fundação Florestal. Disponível em: http://fflorestal.sp.gov.br/unidades-deconservacao/apas-marinhas/apas-marinhas-area-de-protecao-ambiental-marinha/.

Acesso em 28 Jan. 2014.

FREITAS, R.O. 1976. Definição petrológica, estrutural e geotectônica das cintas orogênicas antigas do litoral norte do estado de São Paulo. Boletim do Instituto de Geociências, 1: 1-175. 1976.

FOLMANN, A.C.; PINTO, M.G.C.; GUIMARÃES, G.B. Trilhas interpretativas como instrumento de geoturismo e geoconservação: caso da trilha do Salto São Jorge, Campos Gerais do Paraná. 2010. Geo UERJ - ano 12, n²1. Vol.12, $2^{\circ}$ semestre de 2010.

GARCÍA-CORTÉS, A.; CARCAVILLA URQUÍ, L. C. Documento metodológico para laelaboración del inventario Español de lugares de interés geológico (IELIG). Version 12, 18-05-2009. Instituto Geológico y Minero de España. 2009. Disponível em: http://w.igme.es/ internet/patrimonio/. Acesso em 22 Mai. 2014.

GARCIA, M.G.M. Gondwana Geodiversity and Geological Heritage: Examples from the North Coast of São Paulo State, Brazil. Anuário do Instituto de Geociências - UFRJ. Vol. $35-1 / 2012101-111$ p.

GARDA, G.M.; JULIANI, C.; SCHORSCHER, H.D.; BOHLAND NETO, F. Vulcanismo recorrente e feições geológicas afins em diques básico-ultrabásicos da Praia Vermelha do Sul, município de Ubatuba/SP. Bol. IG-USP, Publicação especial. no.12 São Paulo May 1992. 45 p. 
GARDA, G.M. Os Diques Básicos e Ultrabásicos entre as cidades de São Sebastião e Ubatuba, Estado de São Paulo. 1995. 156f e anexos. Tese de Doutorado, Instituto de Geociências, Universidade de São Paulo, 1995.

GARDA, G.M.; SCHORSCHER, J.H.D. Os diques costeiros básicos e ultrabásicos adjacentes ao Canal de São Sebastião (Litoral Norte do Estado de São Paulo). Revista do IG, v. 17, n.1/2, p.7-31, 1996.

GASPARINI, P. \& MANTOVANI, M.S.M. 1979. Geochemistry of charnockites from São Paulo State, Brazil. Earth and Planetary Science Letters, 42: 311-320.

GEOSSIT. Disponível em: http://www.cprm.gov.br/geossit/geossitios. Acessado em: 04 de Jul. 2014.

GRAY, M. Geodiversity: Valuing and Conserving Abiotic Nature. Chichester: John Wiley and Sons, 2004. 434p.

GRAY, M. Geodiversity: the origin and evolution of a paradigm. In: BUREK, C.V. \& PROSSER, C.D. (Ed). The History of Geoconservation. Geological Society Special Publication 300. London: The Geological Society, 2008. 312pp.

GRUTAS DEL PALACIO GEOPARK - Apresentação e Histórico do Geoparque Grutas Del Palacio. Disponível em: http://www.grutasdelpalacio.org.uy/pg/historia.html. Acesso em 20 Fev. 2014.

GUEDES E., HEILBRON M., VASCONCELOS P.M., VALERIANO C.M., ALMEIDA J.C.H., TEIXEIRA W., THOMAZ FILHO A., 2005. K-Ar and 40Ar/39Ar ages of dykes emplaced in the onshore basement of the Santos Basin, Resende area, SE Brazil: implications for the south Atlantic opening and Tertiary reactivation. Journal of South American Earth Sciences 18:371-382.

HASUI, Y. A grande colisão pré-cambriana do sudeste brasileiro e a estruturação regional Geociências, UNESP, São Paulo, v.29, n.2, p.141-169, 2010.

HASUI, Y., DANTAS, A.S.L., CARNEIRO, C.D.R., BISTRICHI, C.A., 1981. O embasamento pré-cambriano e eopaleozóico em São Paulo. In: Mapa Geológico do Estado de São Paulo. Pró-Minério/IPT, v. 1, p. 12-45.

HEILBRON, M.; VALERIANO C.M.; VALLADARES, C.S.; MACHADO, N. A orogênese Brasiliana no segmento central da Faixa Ribeira, Brasil. Revista Brasileira de Geociências,São Paulo, v. 25, p. 249-266, 1995.

HEILBRON, M.; MOHRIAK, W.; VALERIANO, C.M.; MILANI, E.; ALMEIDA, J.C.A.; TUPINAMBÁ, M. From collision to extension: the roots of the southeastern continental margin of Brazil. In: MOHRIAK, W.U.; TALWANI, M. (Eds.) Atlantic rifts and continental margins. Washington: American Geophysical Union, Geophysical Monograph Series, 2000 , p. 1-32. 
HEILBRON, M., MACHADO, N., 2003. Timing of terrane accretion in the Neoproterozoic-Eopaleozoic Ribeira orogen (SE Brazil). Precambrian Research 125: 87112.

HEILBRON, M.; PEDROSA SOARES, A. C.; CAMPOS NETO, M. C.; SILVA, L. C.; TROW, R. A. J.; JANASI, V. A. Província Mantiqueira. In: MANTESSO-NETO, V. (Coord.). Geologia do Continente Sul-Americano, São Paulo: Beca, 2004. Cap. XIII, p. 233-242.

HEILBRON, M.; VALERIANO, C.M.; TASSINARI, C.C.G.; ALMEIDA, J.C.H.; TUPINAMBA, M.; SIGA, O.; TROUW, R.A.J. Correlation of Neoproterozoic terranes between the Ribeira Belt, SE Brazil and its African counterpart: comparative tectonic evolution and open questions. In: PANKHURST, R.J.; TROUW, R.A.J.; BRITO NEVES, B.B.; DE WIT, M.J. (Eds) West Gondwana: Pre-Cenozoic Correlations Across the South Atlantic Region. London: Geological Society, Special Publications, v.294, p.211-238, 2008.

HIGA, K. K. Diques da Ilhabela-SP: Padrão tectônico e divulgação geocientífica. 2011. 59 f. Trabalho de Conclusão de Curso (Geologia). Instituto de Geociências. Universidade de São Paulo, São Paulo, 2011.

HIRUMA, S.T.; RICCOMINI, C.; MODENESI-GAUTTIERI, M.C.; HACKSPACHER, P.C.; NETO, J.C.H.; FRANCO-MAGALHÂES, A.O.B. Denudation history of the Bocaina Plateau, Serra do Mar, southeastern Brazil: Relationships to Gondwana breakup and passive margin development. Gondwana Research, v.18, p.674-687, 2010.

HOSE T.A., 1995. Selling the Story of Britain's Stone. Environmental Interpretation, 2: 16-17.

HOSE, T.A. Geological interpretation and geoconservation promotion for tourists. In: BARRETINO, D.; WIMBLEDON, W.A.P.; GALLEGO, E. (Ed.). Geological heritage: its conservation and management. Madrid: Sociedad Geologica de España, Instituto Tecnologico GeoMinero de España/ ProGEO, p.127-146, 2000.

IF - Instituto Florestal. Disponível em: http://iflorestal.sp.gov.brl. Acesso em 20 Jan. 2014.

IG - Instituto Geológico. Disponível em: http://igeologico.sp.gov.br/mugeo/monumentosgeologicos/. Acessado em 05 Out. 2014. 
JACOBI, P. Educar para a Sustentabilidade: complexidade, reflexibilidade, desafios. Revista de Educação e Pesquisa (FEUSP), São Paulo, v. 31/2, p. 1-31, maio-agosto. 2005.

KOZLOWSKI, S. Geodiversity. The concept and scope of geodiversity. Przeglad Geologiczny, vol.52, no. 8/2, p. 833-837, 2004.

LARIZZATTI, J.H.; MENEZES, R.G. Rochas ornamentais de revestimentos: conceitos, tipos e caracterização tecnológica. 2005. Departamento de Geologia da Universidade Federal do Rio de Janeiro - UFRJ, em associação com o Centro de Tecnologia Mineral - CETEM - do Ministério de Ciência e Tecnologia e Centro Tecnológico de Mármore e Granito - CETEMAG (ES), 14 p. 2005.

LICCARDO, A.; PIEKARZ, G.F. e SALAMUNI, E. Geoturismo em Curitiba, Curitiba PR, 2008.

LIMA, F.L. Proposta metodológica para o inventário do patrimônio geológico brasileiro. 2008. 170 p. Dissertação de Mestrado, Escola de Ciências da Universidade do Minho, Portugal. 2008.

LENHARE, B.D. Potencial espeleológico em granitos e gnaisses. Disponível em: http://www.culturallmind.com/2011/potencial-espeleologico-em-granitos-e-gnaissesparte-i/. Acesso em 15 Mai. 2014.

MAGALHÃES, J.T.R. Petrogênese das rochas máficas alcalinas do litoral entre São Sebastião (SP) e Parati (RJ). 2012. 236 f. Dissertação de Mestrado, Faculdade de Geologia, Universidade do Estado do Rio de Janeiro. 2012.

MANOSSO, F.C. Geodiversidade, Geoturismo e Patrimônio Geológico: necessidade da conservação. Unioeste Geografia, São Paulo, v. 1 e 2, p.102 - 112, 2009.

MATOSSO, A. Q. (Coord.). Parque Estadual da Serra do Mar: Plano de Manejo Resumo Executivo. São Paulo. 1- 26 p. 2006.

MEDINA, W.M. Propuesta Metodológica para el inventario del Patrimônio Geológico de Argentina. 2012. 106 p. Dissertação de Mestrado, Escola de Ciências da Universidade do Minho, Portugal, 2012.

MELLO, I.J.S. Anisotropias Magnéticas, Magnetismo de Rocha e Paleomagnetismo dos diques de Ubatuba (SP). 2008. 38f. Trabalho de Formatura (TF), Instituto de Geociências, Universidade de São Paulo, 2008.

MINEROPAR. Minerais do Paraná. Geoturismo no Karst. Curitiba, 2011. 121 p. 1.Geoturismo Karst. 2. Geologia - Turismo - Almirante Tamandaré, Campo Magro , Colombo. I. Piekarz, G., II. Título. 2011. 
MOCHIUTTI, N.F. Os valores da geodiversidade da região de Piraí da Serra, Campos Gerais do Paraná. Trabalho de Conclusão de Curso, Universidade Estadual de Ponta Grossa, Paraná, 127 p. 2009.

MOREIRA, J. C. Patrimônio geológico em unidades de conservação: atividades interpretativas, educativas e geoturísticas. 2008, 428 f. Tese de Doutorado, Universidade Federal de Santa Catarina, Florianópolis, 2008.

MOREIRA, J. C. Geoturismo e interpretação Ambiental. Ponta Grossa: Editora: UFPG, 2011. 157p.

MMA - Ministério do Meio Ambiente. Disponível em: http://www.mma.gov.br/areasprotegidas/sistema-nacional-de-ucs-snuc. Acesso em 28 Jan. 2014

MT - Ministério do Turismo. Disponível em: http://www.turismo.gov.br/turismo/home.html. Acesso em 28 Jan. 2014.

NATURTEJO - Naturtejo Geopark. Disponível em: http://www.naturtejo.com. Acesso em 20 Fev. 2014.

NIETO, L.M. Geodiversidad: propuesta de una definición integradora. Boletín Geológico y Minero- España, Vol. 112, No 2, p. 3-12, 2001.

NEUMANN, R. Contribuição à Petrologia das Rochas Charnockíticas de Ubatuba, Leste do Estado de São Paulo. 1993. $86 f$ e anexos. Dissertação de Mestrado, Instituto de Geociências, Universidade de São Paulo, 1993.

OLIVEIRA, S. M. Ilha Anchieta - rebelião, fatos e lendas. - 4 ed. - Pindamonhangaba, SP: autor, 2009, $186 \mathrm{p}$.

PEREIRA, R.G.F.A. Geoconservação e desenvolvimento sustentável na Chapada Diamantina (Bahia - Brasil). 2010. 295 p. Tese de Doutorado, Escola de Ciências da Universidade do Minho, Portugal. 2010.

PONÇANO, W.L., ALMERIDA, F.F.A. de, CARNEIROS, C.D.R., BISTRICHI, C.A., PIRES NETO, A.C., ALMEIDA, M.A., PRADINI, F.L., ÁVILA, I.G., FORNASSI FILHO, N., IWASA, O.Y. \& SANTOS, M. do C.S.R. dos. (1981) Mapa geomorfológico do estado de São Paulo. Programa de desenvolvimento de recursos minerais (Pró-Minério) e Companhia de promoção de pesquisa científica e tecnológica do estado de São Paulo (PROMOCET). IPT, Vol. I,94p.

PLATIER, R.D. Gruta que Chora em Ubatuba. Disponível em: http://meioambiente.culturamix.com/natureza/gruta-que-chora-em-ubatuba. Acesso em 15 Mai. 2014. 
PROCHOROFF, R. O patrimônio geológico de llhabela - SP: estratégias de geoconservação. 2014. 175p. Dissertação (Mestrado) - Instituto de Geociências, Universidade de São Paulo, São Paulo, 2014.

PUBLICO PT - Notícias Portugal. Disponível em: http://www.publico.pt/local/noticia/unesco-visita-em-maio-territorio-candidato-ageoparque-terra-de-cavaleiros-1621589. Acesso em 17 Fev. 2014.

REVERTE, F.C. Avaliação da geodiversidade em São Sebastião - SP, como patrimônio geológico - 2014. 208f. Dissertação de Mestrado, Instituto de Geociências, Universidade de São Paulo, 2014.

RICCOMINI, C.; SANT'ANNA, L.G. \& FERRARI, A.L. Evolução geológica do Rift Continental do Sudeste do Brasil. In: MANTESSO-NETO, V.; BARTORELLI, A.; DAL RÉ CARNEIRO, C. \& BRITO NEVES, B.B. (Org.). Geologia do Continente Sul- Americano Evolução da Obra de Fernando Flávio Marques de Almeida. Beca, 2004. p. 383-405.

RICCOMINI, C.; VELÁZQUEZ, V.F.; GOMES, C.B. Tectonic controls of the Mesozoic and Cenozoic alkaline magmatism in central-southeastern Brazilian platform. In: CHIARAMONTI, P.C.; GOMES, C.B (Eds.) Mesozoic to Cenozoic alkaline magmatism in the Brazilian platform. São Paulo: EDUSP, 2005.

ROBIM, M.J., VILAR, D.D., FONSECA, F.P., COCCO, M.D.A. Caminhos para a conservação do Patrimônio Cultural em Unidades de Conservação. O caso do Parque Estadual da Ilha Anchieta. OLAM - Ciência \& Tecnologia, Rio Claro, SP, Brasil. Ano VIII Vol. 8 No.2, 105 - 13- p. Janeiro - Junho / 2008.

RUCHKYS, U. de A. Patrimônio geológico e geoconservação no Quadrilátero Ferrífero, Minas Gerais: potencial para a criação de um geoparque da UNESCO. 2007, 211 f. Tese (Doutorado em Geologia) - Instituto de Geociências, Universidade Federal de Minas Gerais, Belo Horizonte, 2007.

SANTOS, A. R. A Grande Barreira da Serra do Mar: da trilha dos Tupiniquins à Rodovia dos Imigrantes. São Paulo. O Nome da Rosa Ed., 122p. 2004.

SERRANO, E. \& RUIZ-FLAÑO, P. 2007- Geodivesity. A theoretical and applied concept. Geographica Helvetica - Swiss Journal of Geography . Heft-3 - 2007, p. 140-147, 2007.

SHARPLES, C. 2002. Concepts and Principles of Geoconservation. Tasmanian Parks \& Wildlife Service. Disponível em: http://www.dpiw.tas.gov.au/inter.nsf/Attachments/SJON57W3YM/\$FILE/geoconservation.pdf. Acesso em 13 Fev. 2014.

SCHMITT, R. S. A orogenia búzios-um evento tectono metamórfico cambro-ordoviciano caracterizado no domínio tectônico de Cabo Frio - RJ. Anu. Inst. Geociências., 2001, vol.24, p.47-48. 
SCHMITT, R.S., TROUW, R.A.J., VAN SCHMUS, W.R., PIMENTELI, M.M., 2004. Late amalgamation in the central part of Western Gondwana: new geochronological data and the characterization of a Cambrian collision orogeny in the Ribeira Belt (SE Brazil). Precambrian Research 133: 29-61.

SILVA, F. P. da. Petrologia dos diabásios da Região de Ubatuba, SP. 2010132 f. Dissertação de Mestrado, Faculdade de Geologia, Universidade do Estado do Rio de Janeiro. 2010.

SOUZA, C.R.G. Praias arenosas oceânicas do estado de São Paulo (Brasil): síntese dos conhecimentos sobre a morfodinâmica, sedimentologia, transporte costeiro e erosão costeira. Revista do Departamento de Geografia - USP. Vol. Especial 30, 2012, p.307-371.

SULFOGRAFIA. Disponível em: http://surfografia.com/3152-2/capa/casa-do-artesao-deubatubal. Acesso em 02 Out. 2014.

STANLEY, M. Geodiversity - linking people, landscapes and their culture. In: Natural and Cultural Landscapes - The Geological Foundation, M.A. Parkes (Ed.), Royal Irish Academy, Dublin, Ireland, p. 47-52, 2004.

TESSLER, M.G., MAHIQUES, M.M.; RODRIGUES, M. Sedimentação atual nas enseadas de Ubatumirim e Picinguaba, região norte de Ubatuba, estado de São Paulo, Brasil. 2002. Revista brasileira de Oceanografia, 50 (vol. Único): 27-45 p.

THOMPSON, R.N., GIBSON, S.A., MITCHELL, J.G., DICKIN, A.P., LEONARDOS, O.H., BROD, J.A., GREENWOOD, J.C., 1998. Migration Cretaceous-Eocene Magmatism in the Serra do Mar Alkaline Province, SE Brazil: Melts from the Deflected Trindade Mantle Plume? Journal of Petrology 39(8): 1493-1526.

TROMPETTE, R.; EGYDIO-SILVA, M.; TOMMASI, A.; VAUCHEZ, A.; UHLEIN, A. Amalgamação do Gondwana Ocidental no Panafricano - Brasiliano e o Papel da Geometria do Cráton São Francisco na Arquitetura da Faixa Ribeira. Revista Brasileira de Geociências 23(3):187-193, Setembro de 1993.

TUPINAMBÁ, M., HEILBRON M., DUARTE, B.P., NOGUEIRA, J.R., VALLADARES, C., ALMEIRDA, J., EIRADO SILVA, L.G., MEDEIROS, S.R., ALMEIDA, C. G., MIRANDA, A., RAGATKY, C.D., MENDES, J., LUDKA, I., 2007. Geologia da Faixa Ribeira Setentrional: estado da arte e conexões com a Faixa Araçuaí. Geonomos 15(1): 67-79.

TUPINAMBÁ, M., HEILBRON, M., VALERIANO, C., PORTO JÚNIOR, R., BLANCO de DIOS, F., MACHADO, N., EIRADO SILVA, L.G., ALMEIDA, J.C.H., 2012. Juvenile contribution of the Neoproterozoic Rio Negro Magmatic Arc (Ribeira Belt, Brazil): Implications for Western Gondwana Amalgamation. Gondwana Research 21: 422-438.

TROMPETTE, R.; EGYDIO-SILVA, M.; TOMMASI, A.; VAUCHEZ, A.; UHLEIN, A. Amalgamação do gondwana ocidental no panafricano-brasiliano e o papel da geometria 
do cráton do São Francisco na arquitetura da Faixa Ribeira. Revista Brasileira de Geociências, v.23, n.3, p. 187-193, 1993.

TROUW, R.A.J.; HEILBRON, M.; RIBEIRO, A.; PACIULLO, F.V.P.; VALERIANO, C.M.; ALMEIDA, J.C.H.; TUPINAMBÁ, M.; ANDREIS, R.R. The central segment of the Ribeira Belt. In: CORDANI, U.G.; MILANI, E.J.; THOMAZ FILHO, A. (Ed.) Tectonic Evolution of South America, p. 287-310. 2000.

UBATUBA. Prefeitura municipal de Ubatuba. Disponível em: http://www.conhecaubatuba.com.br/ubatuba/Noticias.asp?Not=3839\&VP=Not3839.

Acesso em 02 Out. 2014.

UCEDA, A.C. Patrimônio geológico; diagnóstico, clasificación y valoración. In: SuárezValgrande, J.P (Ed.) Jornadas sobre Património Geológico y Desarrollo Sostenible, Serie Monografías, Ministério de Medio Ambiente de España, p. 23-37, 2000.

UNESCO - Convenção para a Proteção do Patrimônio Mundial, Cultural e Natural. Organização das Nações Unidas para a Educação, a Ciência e a Cultura. Paris/ França, 1972. Disponível em: http://www.unesco.org/culture/ich/en/convention. Acesso em 30 jan. 2014.

UNESCO - Text of the Convention for the Safeguarding of Intangible Cultural Heritage. 2003. Disponível em: http://www.unesco.org/culture/ich/en/convention. Acesso em 28 jan. 2014.

UNESCO - Geoparques no Chile. Disponível em: http://www.unesco.org.uy/geo/pt/areas-de-trabajo/ciencias-naturales/ciencias-de-latierra/temas/geoparques-en-alc/geoparques-en-chile.html. Acesso em 20 Fev. 2014.

VALENTE, S.C., CORVAL, A., DUARTE, B.P., ELLAM, R.M., FALLICK, A.E., MEIGHAN, I.G., DUTRA, T., 1997. Tectonic boudaries, crustal weakness zones and plume-subcontinental lithosferic mantle interactions in the Serra do Mar dyke swarm, SE Brazil. Revista Brasileira de Geociências 37(1): 194-201.

VASCONCELOS, J.M.O. Interpretação e manejo de trilhas. In: MITRAUD, S. (org). Manual de Ecoturismo de Base Comunitária: ferramentas para um planejamento responsável. WWF Brasil, 2003. 470p.

VARGAS, T.; MOTOKI, A.; NEVES, J.L.P. Rochas ornamentais do Brasil, seu modo de ocorrência geológica, variedade tipológica, explotação comercial e utilidades como materiais nobres de construção. 2001. Revista de Geociências, Instituto de Geociências - UFF. 2-2, 119-132. 2001. 
ANEXOS 


\section{GEOCIÊNCIAS}

TRILHA DA BRAVA DA ALMADA - ROTEIRO GEODIDÁTICO

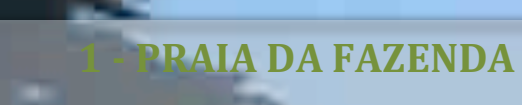

A primeira feição geológica que observaremos em nossa caminhada serão as pequenas caminhada serão as pequenas
marcas onduladas na areia. Elas marcas onduladas na areia. Elas
são causadas pelo fluxo de água são causadas pelo fluxo de água rasa do mar, que vai pra praia e volta, carregando os grãos minerais que compóem a areia da praia. Os grãos mais claros e mais escuros formam faixas alinhadas nas partes mais elevadas e mais Isso acontece porque a água baixas destas ondas.

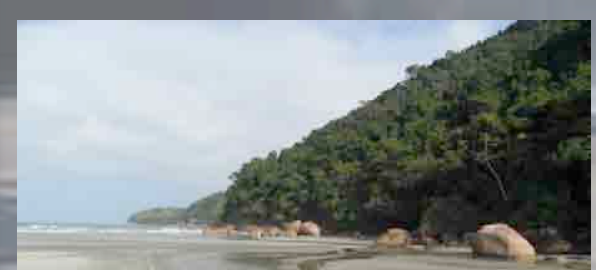
dransporta os grãos de maneiras diferentes, dependendo do seu tamanho e da sua densidade. As dunas, comuns em algumas praias, também são formadas de modo parecido, só que pelo vento.

Outra feição que pode ser destacada são as finas camadas de sedimentos depositados na beirada do rio, à medida que a água vai transportando os grãos.

\section{6 - MIGMATITOS}

Migmatitos são rochas mistas, ou seja, formadas por uma mistura de partes ígneas (mais claras) e metamórficas (mais escuras). Elas ocorrem porque, quando as rochas são levadas a grandes profundidades, sob altas pressões e temperaturas, elas sofrem metamorfismo e os minerais com menor ponto de fusão "derretem" menor poqueles com ponto de fus̃ antes daqueles com ponto de fusão
maior e as duas porções se misturam.

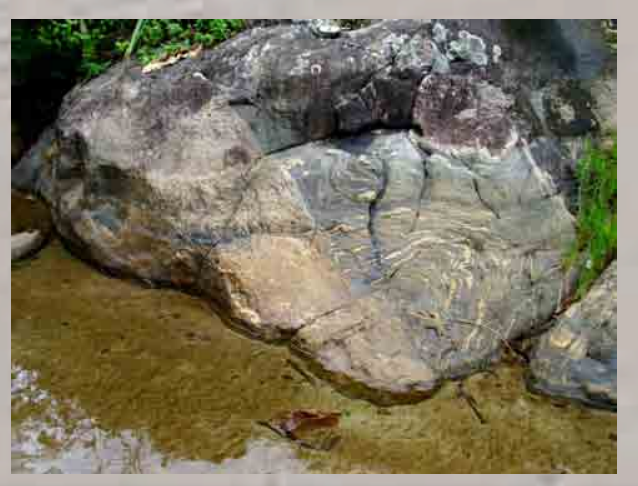

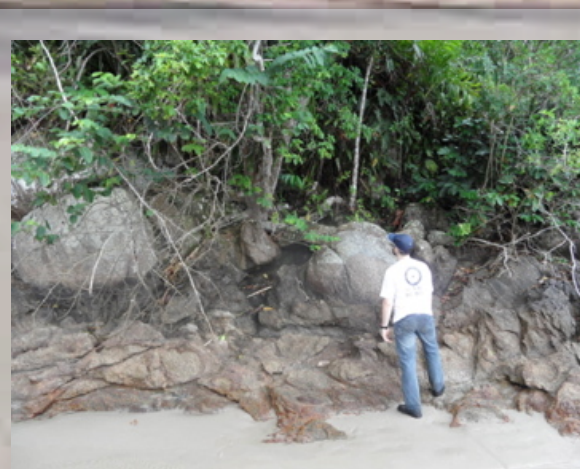

A porçao mais clara e a rocna ígnea - granito, mais nova, enquanto que a parte escura é a rocha metamórfica, mais antiga gnaisse.

A Serra do Mar é formada por rochas "cristalinas", ou seja, ígneas e metamórficas. Migmatitos são um tipo de rocha comum aqui na Serra do Mar e é como as rochas igneas, como é o de Ubatuba", que recebe o nome técnico de charnockito.
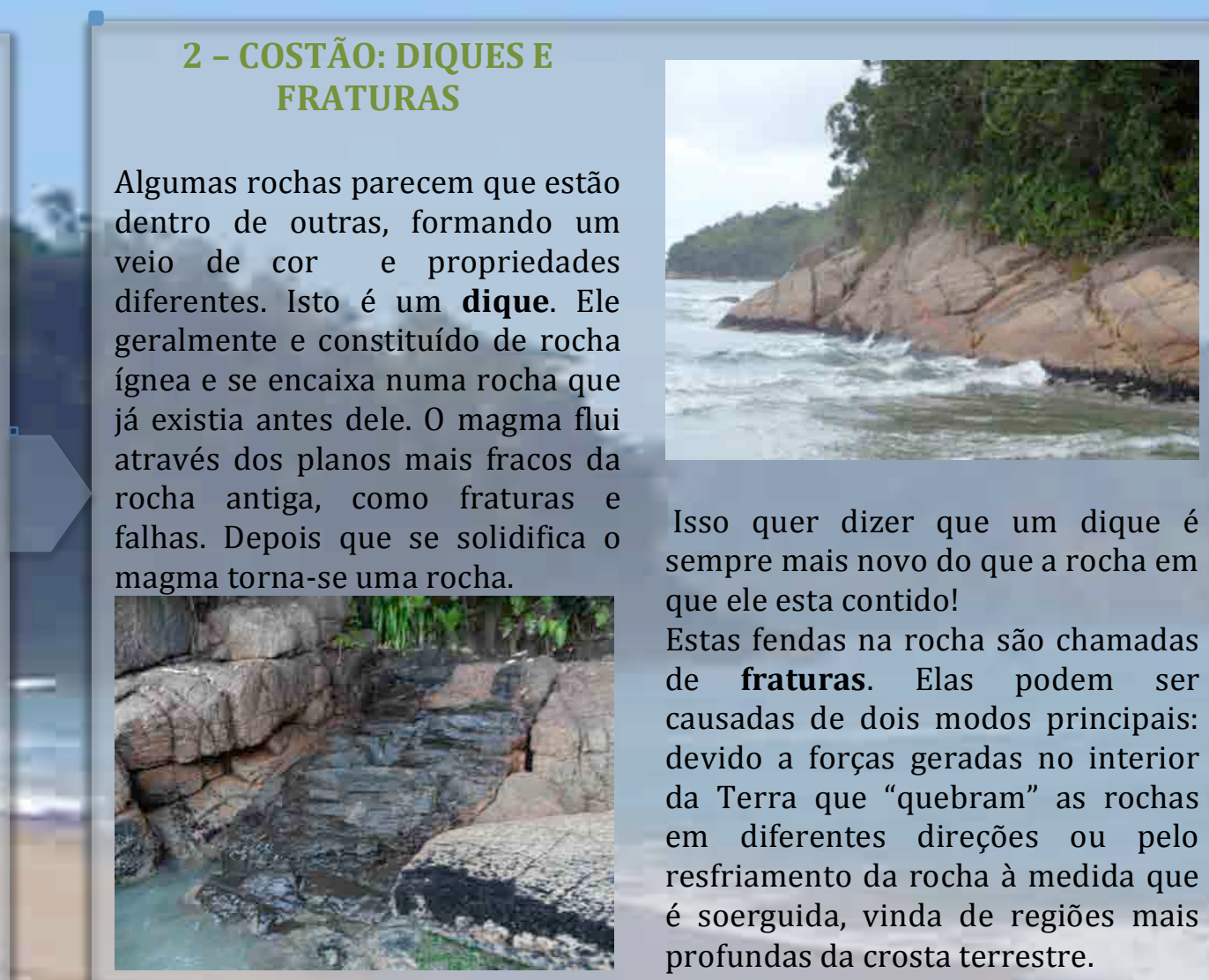

Isso quer dizer que um dique é sempre mais novo do que a rocha em que ele esta contido!

Estas fendas na rocha são chamadas de fraturas. Elas podem ser causadas de dois modos principais: devido a forças geradas no interior da Terra que "quebram" as rochas em diferentes direções ou pelo resfriamento da rocha à medida que é soerguida, vinda de regiões mais profundas da crosta terrestre.

\section{5 - ILHAS E QUEBRA DOS CONTINENTES}

Olhe o oceano à sua frente. As ilhas, Comprida e das Couves, são compostas por rochas semelhantes às observadas nos costões das praias, no continente. Elas também parecem estar alinhadas com a ponta do continente. Além desta imensidão, está o continente africano que, juntamente com a América do Sul, fazia parte de um grande continente chamado Gondwana e cuja separação começou há mais ou menos 140 milhões de anos atrás. As ilhas que hoje vemos são partes do continente hoje cobertas pelas águas do Oceano Atlântico.

É possível também observar o ambiente de restinga, caracterizada por um tipo de vegetação costeira que sofre bastante influência do mar formada sobre solo arenoso pouco nutritivo, com vegetação formada por espécies sobre solo aresco couco nutrivo, com vegetaça formada por esph recuo do mar.

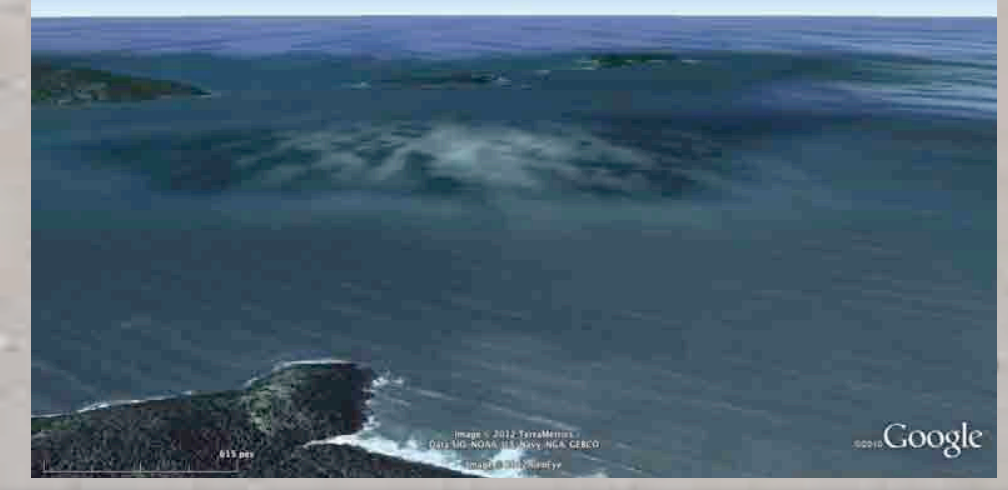

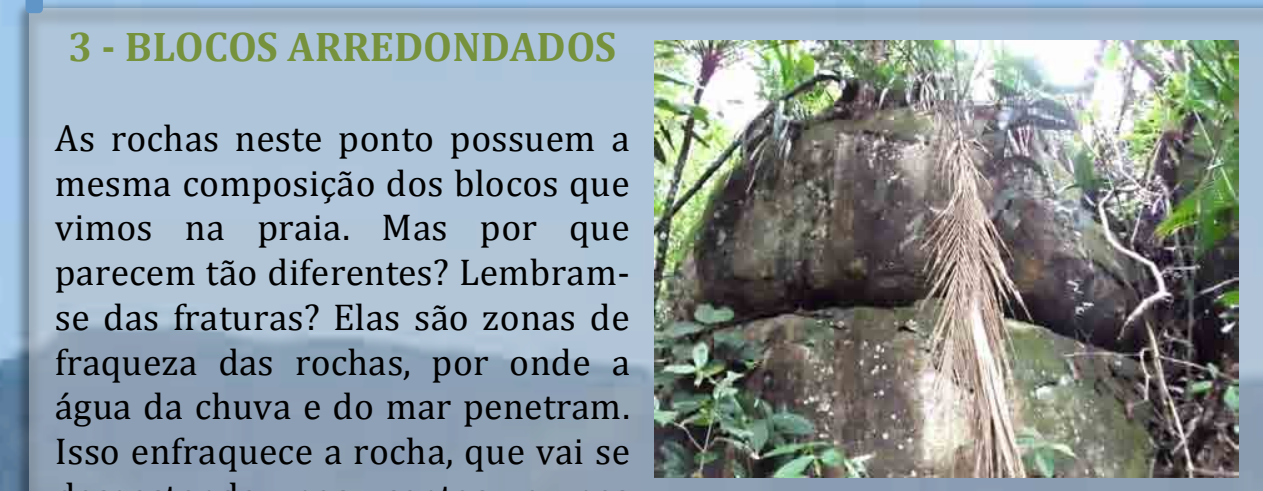

Isso enfraquece a rocha, que vai se desgastando nos cantos e nas arestas, alargando as fraturas. Os grãos que formam a rocha vão se soltando e se depositando na praia.

A praia é o destino final destes sedimentos, ou seja sua área-fonte! Reparem nas raízes das árvores entrando nas partes fraturadas das rochas. Assim como a água pode fragmentar a rocha, as plantas também podem e esta degradação se chama intemperismo. No caso deste ponto, os grãos que se soltam estão formando o solo do local e servindo de base para 0

crescimento da cobertura vegetal. $=$ - PRAIA DAS CONCHAS

Neste ponto podem ser observadas rochas claras e escuras, que aparecem juntas porque ainda não estavam solidificadas e se misturaram. Estas rochas são as mesmas que ocorrem nas montanhas e também foram desgastadas pelo intemperismo, formando a areia da praia. Ao contrário da Praia da Fazenda, aqui o tamanho dos grãos varia bastante, resultado da proximidade do morro e, em proximidade do morro e,
consequência, pouco transporte.

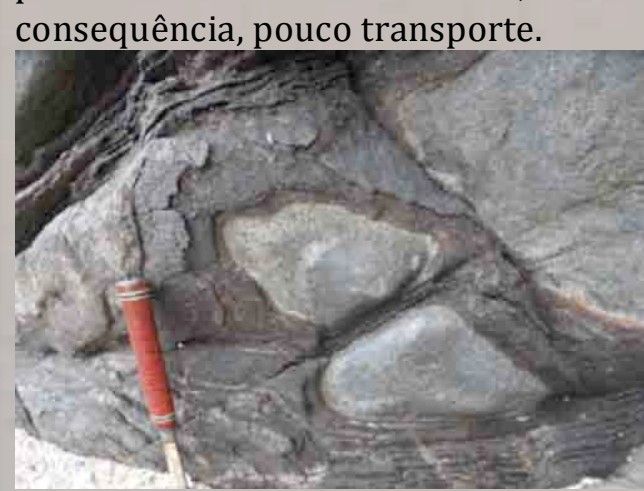
longa distância para chegar até a raia e por isso são mais finos e mais arredondados.

Quando a rocha não tem planos de fraturas e nem minerais orientados, o intemperismo atua ragmentando-a de fora para dentro, formando camadas que parecem "cascas de cebolas". Isso se chama esfoliação esferoidal e ocorre geralmente em rochas maciças, tais como o basalto. 


\section{GEOCIÊNCIAS}
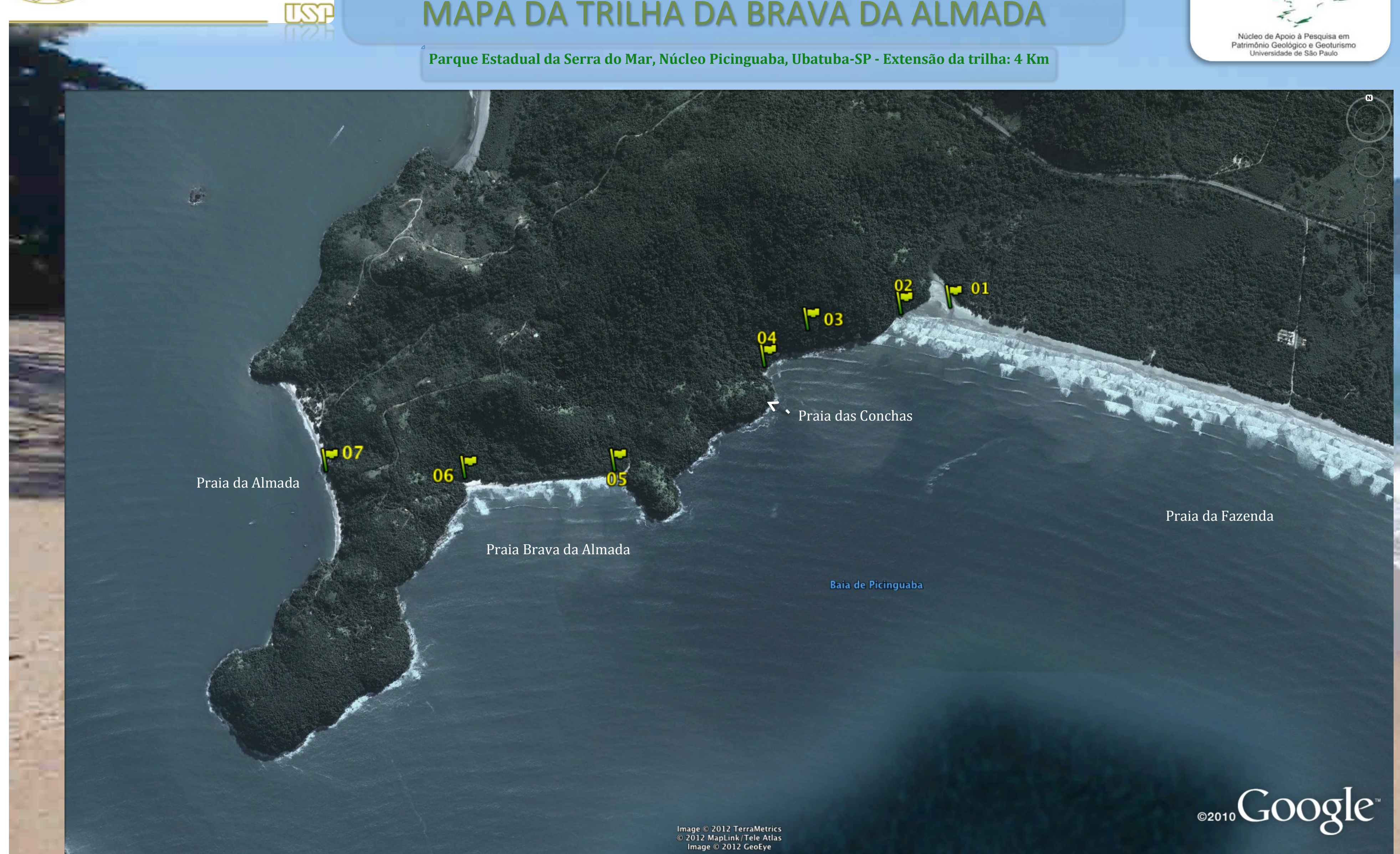


\section{4 (cont.): DEPOSIÇÃO DE SEDIMENTOS}

Além dos blocos maiores, a água do rio transporta também sedimentos mais finos, como a areia, e vai depositando estes grãos à medida que perde força, sob a forma de finas camadas. Esse processo é chamado de estratificação. A água do rio traz sedimentos de regiões mais altas, formados devido à decomposição das rochas que compõem as montanhas. Por isso, as camadas podem ter cores variadas, dependendo do local de onde vêm os sedimentos.

As marcas onduladas que você vê na areia são decorrentes do fluxo de água rasa do mar e do rio, que carregam os grãos minerais claros e escuros. Os grãos mais pesados concentram-se preferencialmente nos locais mais baixos, enquanto os mais leves podem atingir os locais mais altos, resultando num padrão "listrado" como o observado aqui.
5: ROCHA DOBRADA

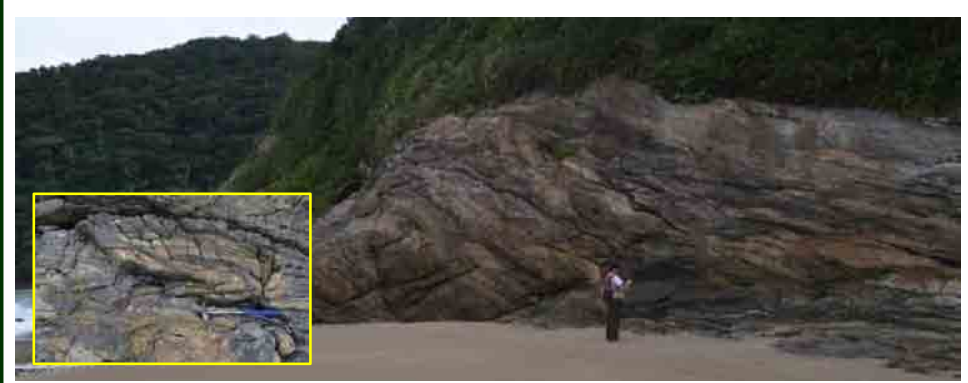

As rochas, quando submetidas a forças compressivas, altas pressões e temperatura, podem se deformar, resultando em uma rocha dobrada.
Imagine dois grandes continentes sendo comprimidos um contra o outro. A força desta compressão deforma as rochas, gerando um tipo de estrutura denominada "dobra".

Veja como ela se forma: 5
Há cerca de 600 milhões de anos atrás (isso mesmo, o tempo geológico é contado numa escala toda especial!) parte dos continentes existentes no planeta se chocaram, gerando um supercontinente denominado Gondwana, que se fragmentou muito tempo depois (há cerca de 150 milhões de anos).

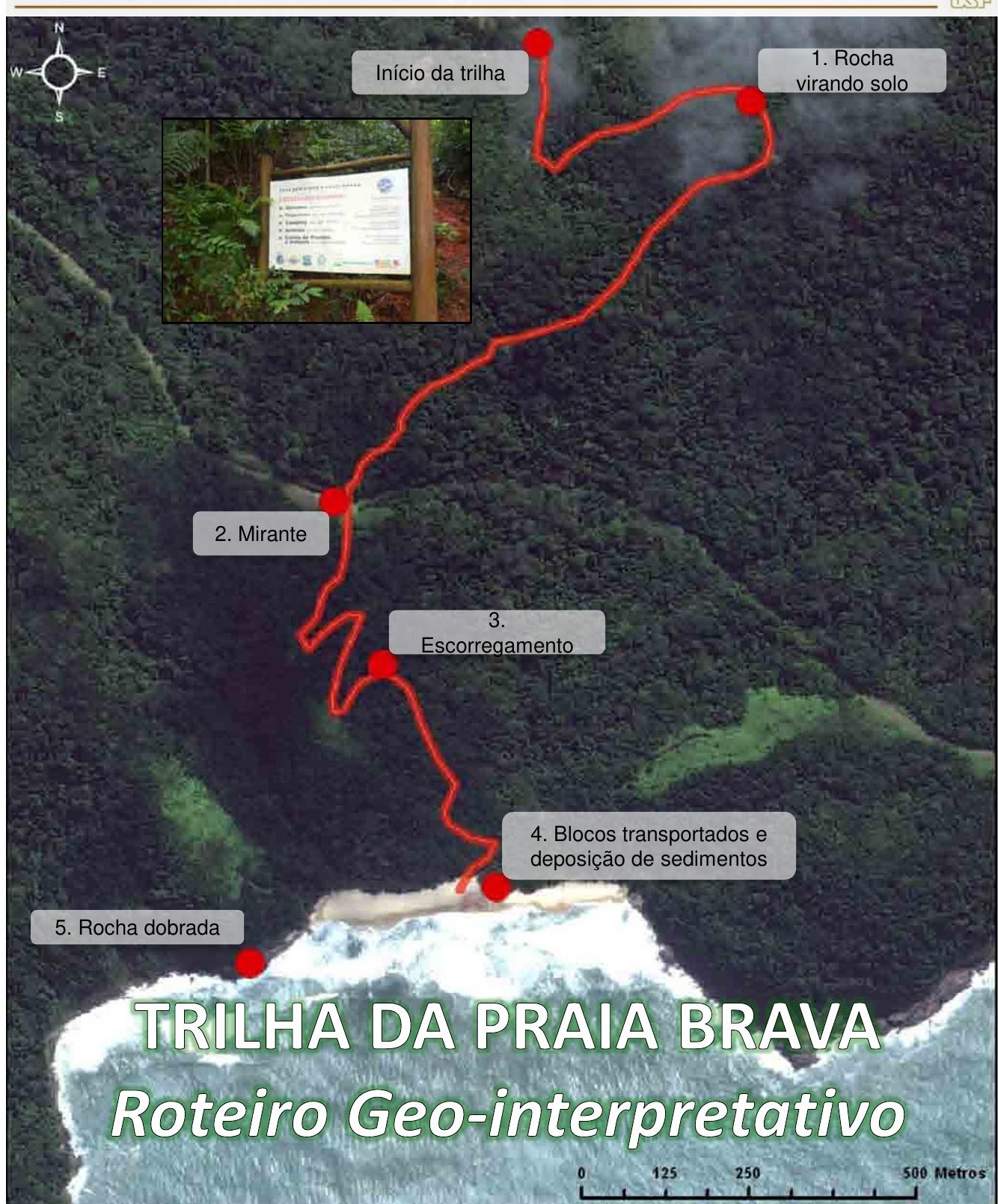




\section{1: ROCHA VIRANDO SOLO}

O solo é o resultado do desgaste das rochas. Os fatores responsáveis por este processo são: o clima (chuva, calor), organismos vivos (plantas, animais), relevo (declividade do terreno), tipos de rochas (mais resistentes ou menos resistentes). Este processo leva milhares anos para acontecer.

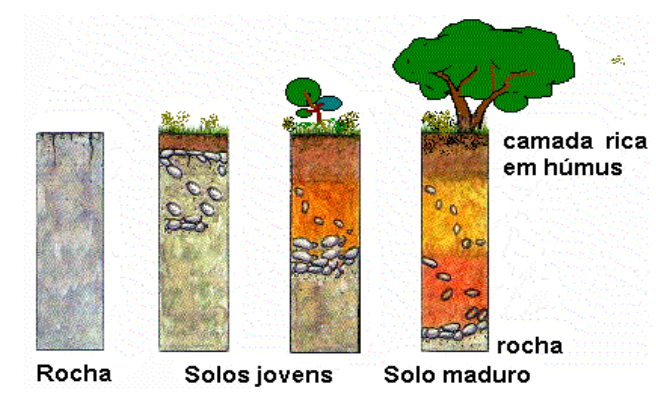

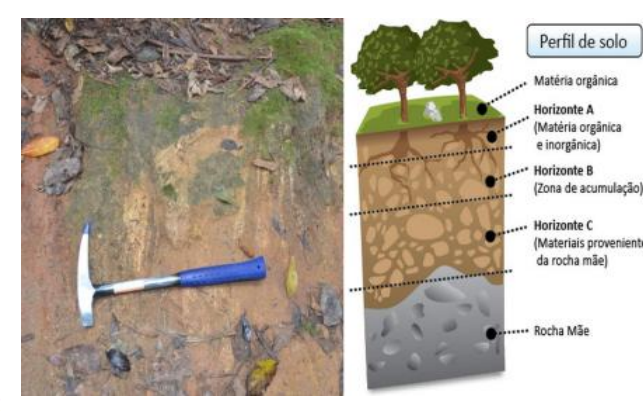

Neste ponto observamos blocos de rocha alterada, que está se transformando no solo encontrado no local. Podemos observar que o solo se encontra no horizonte $C$, pois ainda é possível observar resquícios da rocha que o originou, no caso, a orientação dela, que apresenta direção leste-oeste.

\section{3: ESCORREGAMENTO}

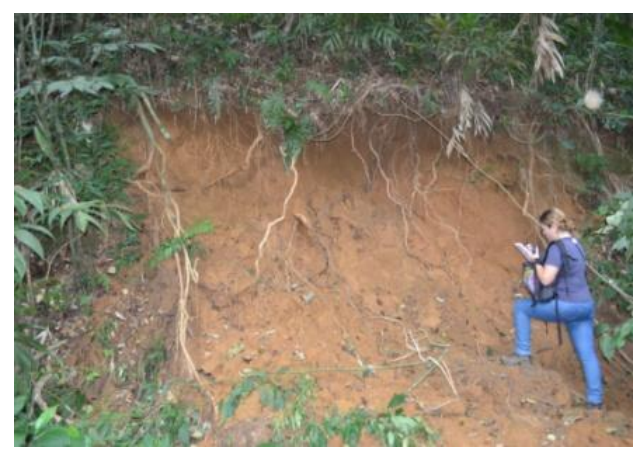

Este escorregamento ocorreu devido às chuvas intensas no verão. O fenômeno é comum na região e ocorre como resposta ao acúmulo de água no solo, associado à inclinação do terreno e a fatores como desmatamento, ocupação desordenada, etc. O escorregamento é apenas uma categoria dos chamados "movimentos de massa", processos de vertente que envolvem o desprendimento e transporte de solo e/ou material rochoso encosta abaixo.

Os movimentos de massa fazem parte da dinâmica natural de transformação e formação da crosta terrestre e estão relacionados também a fenômenos naturais como gravidade e variações climáticas. As encostas da Serra do Mar são naturalmente suscetíveis a fenômenos deste tipo.

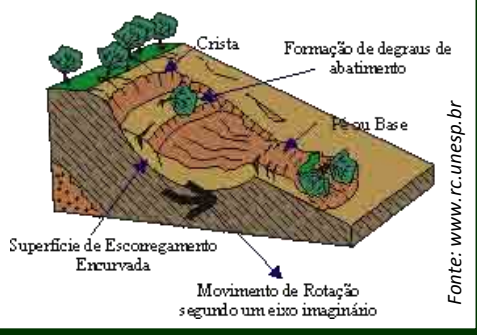

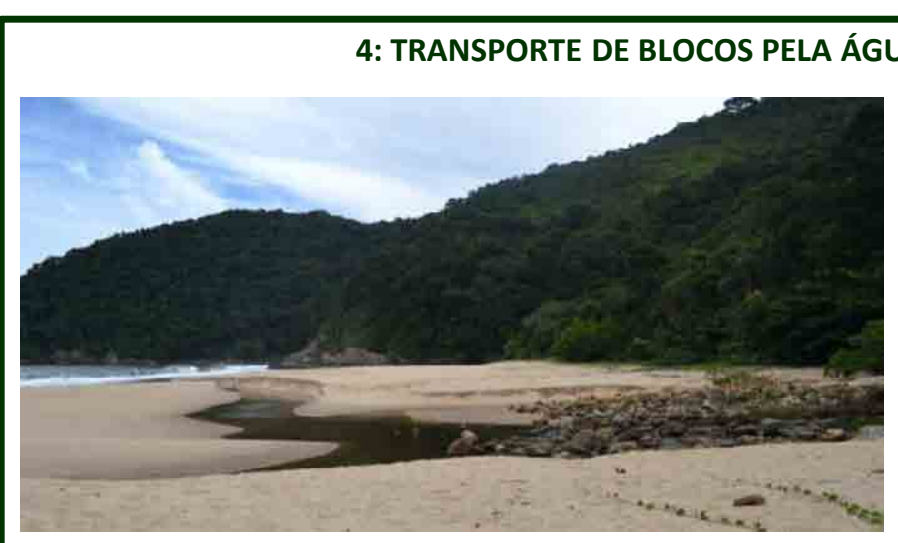

Nas cabeceiras, onde o relevo é em geral acentuado, o rio tem energia suficiente para transportar grandes blocos. À medida que a energia diminui, o mesmo acontece com sua capacidade de transporte e as partículas transportadas tornam-se gradativamente menores.

$\mathrm{O}$ aumento na quantidade de chuva pode fazer com que o rio, eventualmente, transporte partículas maiores do

que as habituais.
O rio que vem da serra e chega à Praia Brava carrega inúmeras partículas de diversos tamanhos. A velocidade da água transporta estas partículas, que são provenientes das rochas que compõem a serra.

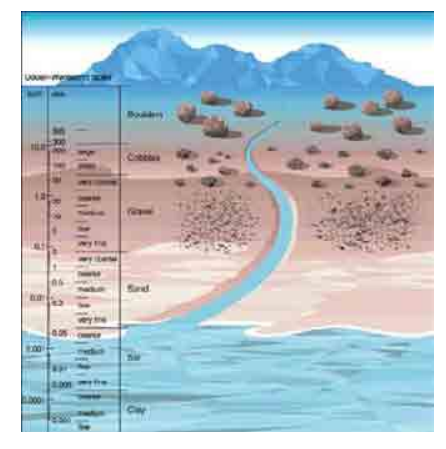

Vista para as praias de Boiçucanga e Camburi e para a imponente Serra do Mar, com suas belas escarpas e o verde marcante da Mata Atlântica à riqueza e diversidade de fauna e flora.

Desde os tempos coloniais, a Serra do Mar funcionou como uma barreira instransponíve para a conquista do interior do país e é parte da história e da cultura da região! 